

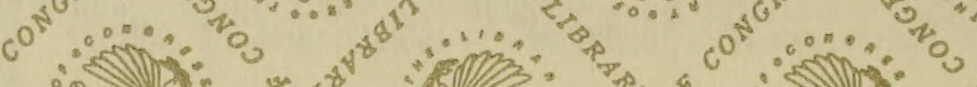

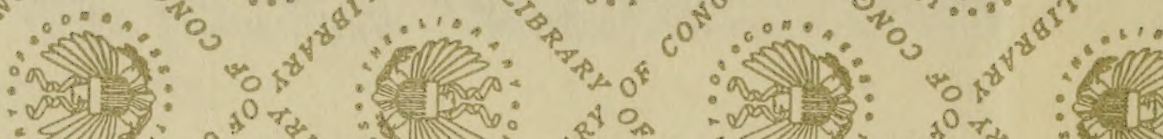

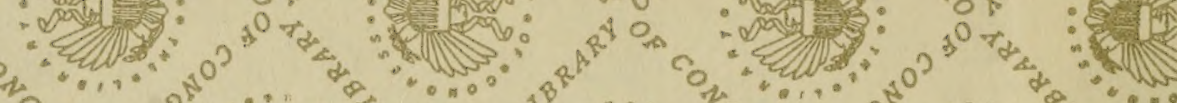

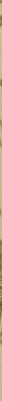

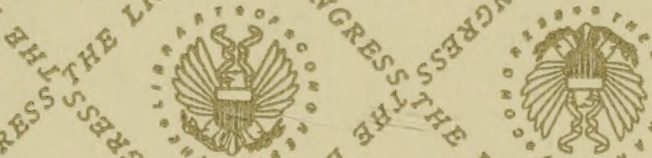

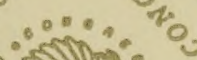

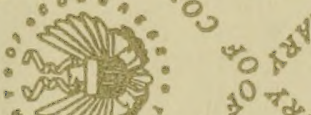
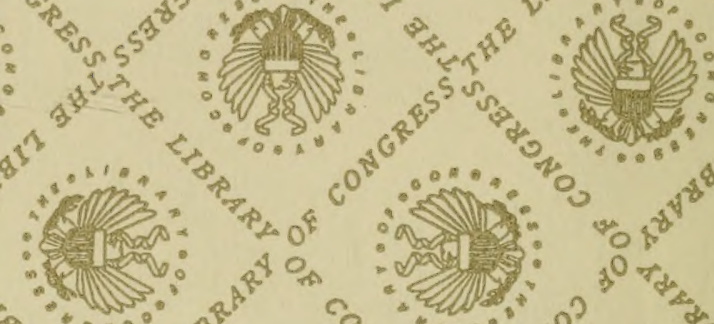

P.$$
\text { . }
$$

\section{.}

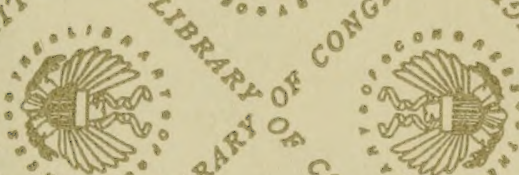

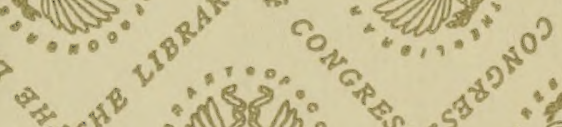
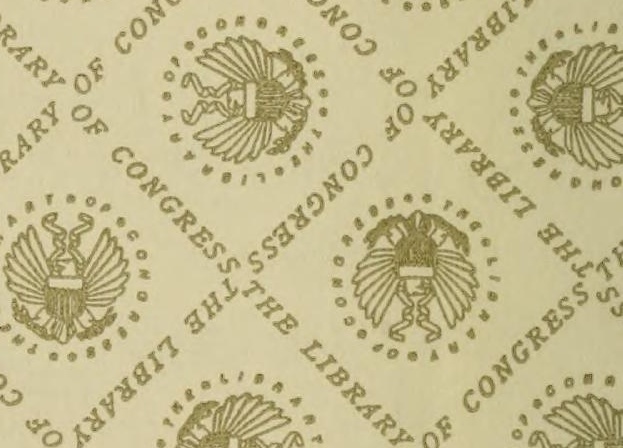

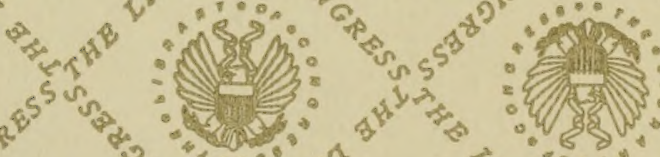

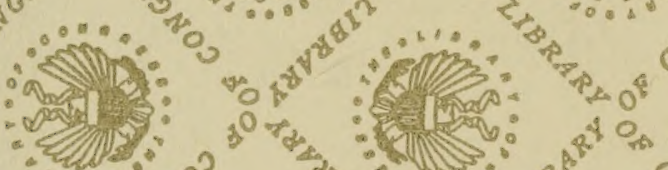

$\mathrm{C}^{\circ} \cdot{ }^{5}$

(3)

$5^{5}$

${ }_{0}{ }_{\infty}$

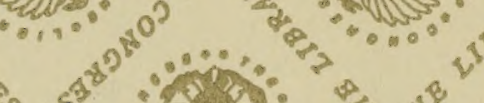

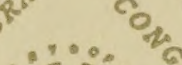

$\because$ Wh

- ovis.

\%

$\mathrm{c}^{\mathrm{s}^{3}} \cdot 0$

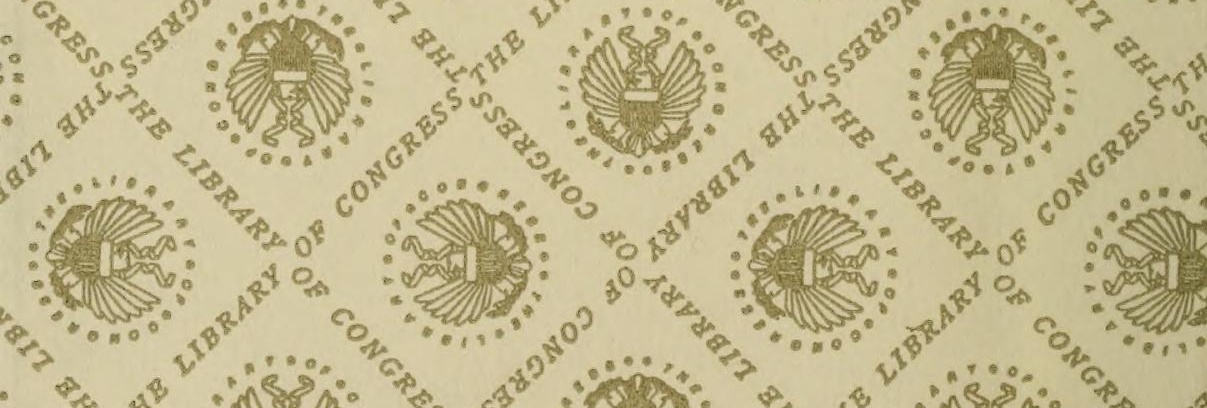

* a 
$0^{04}=0$

$\therefore$ anth:

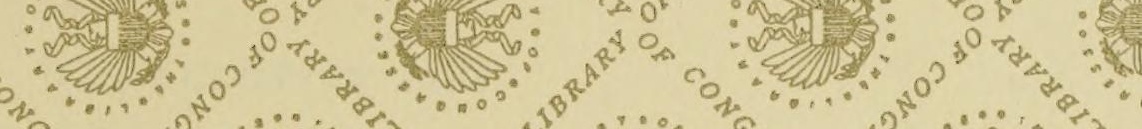
然:

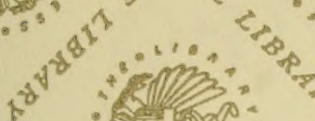
- Evinas

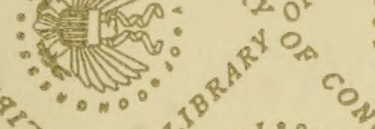

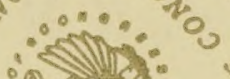

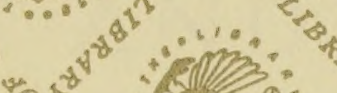

$\therefore$ बत्रा:

201

: $5100^{\circ}$

7

-

${ }_{3} 0$ च

:

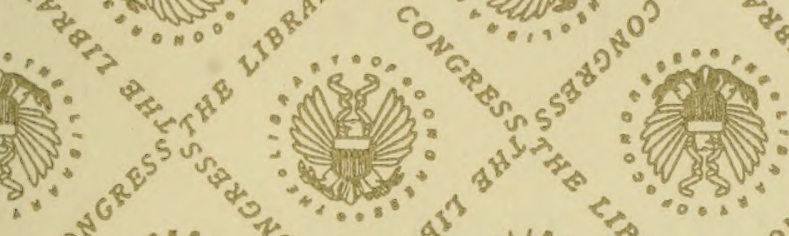

$\mathrm{C}^{0}$

$\therefore$ काजा : :

:090

$\left.{ }_{3}\right)^{7}$

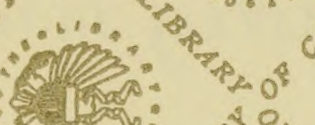

$c^{\infty}$

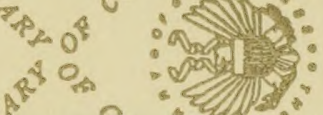

$:$

is

4<smiles>O=C1CCCCC12CCCCO2</smiles>

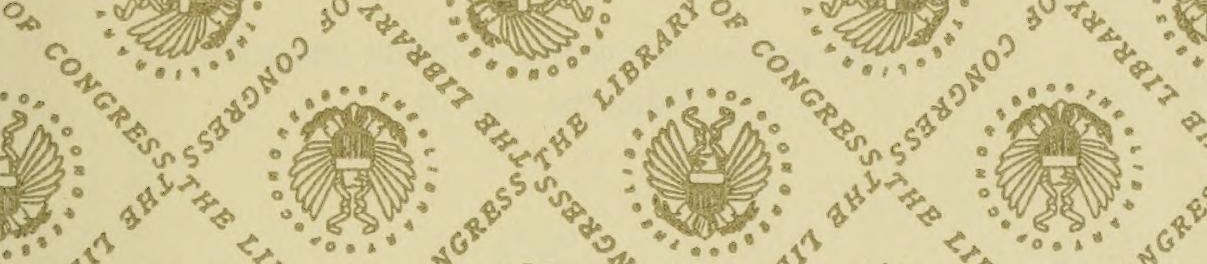

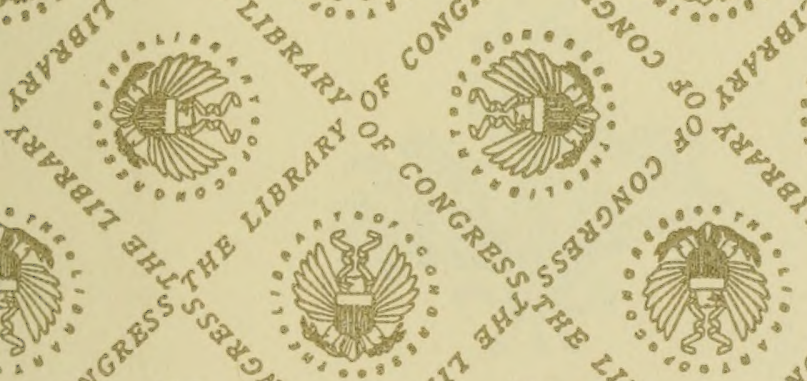

:

$\because$ Q

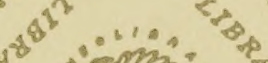

- Dosy

$\lambda^{0}$ मे

"ar ina.

Ps 0

(

$0^{3}$

.

से के

$-\infty$

\%

so

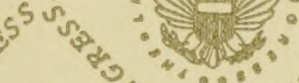



THE "COUNTRY LIFE"

LIBRARY

\section{CHILDREN AND GARDENS}

BY

GERTRUDE JEKYLL

WITH ONE HUNDRED AND SIX ILLUSTRATIONS

BY THE AUTHOR

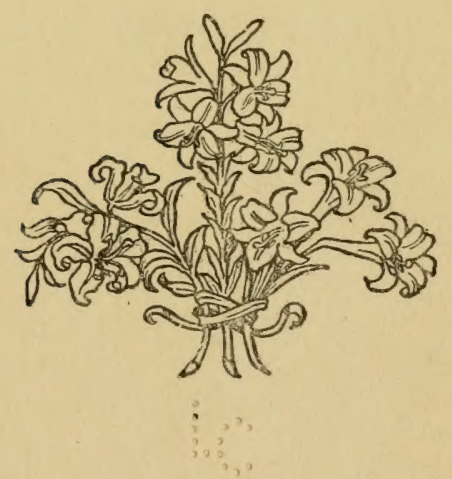

LONDON : PUBLISHED AT THE OFFICES OF 'COUNTRY LIFE,' LTD., TAVISTOCK STREET, COVENT GARDEN, W.C.; GEORGE NEWNES, LTD., SOUTHAMPTON STREET, STRAND, W.C.; AND CHARLES SCRIBNER'S SONS, NEW YORK. MCMVIII 


$$
5^{583^{5}} .55
$$

131088
$\log$

$\therefore \vdots$ 


\section{CONTENTS}

\section{CHAPTER I}

MY OWN YOUNG DAYS . . . . . . I I

CHAPTER II

The Children's Garden and the Play-House * 7

CHAPTER III

EARLY WEEDS . . . . . . . . 24

CHAPTER IV

SEEDS . . . . . . . . . $3 \mathrm{I}$

CHAPTER V

Cowslip Time . . . . . . . . . 44

CHAPTER VI

SMells ANd Shapes . . . . . . 49 


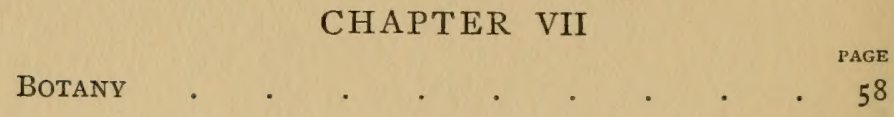

CHAPTER VIII

My First Garden . . . . . . . 65

CHAPTER VIII

CHAPTER IX

FLOWERS FOR YOUR OWN GARDENS . . . . 76

CHAPTER $\mathrm{X}$

Adventures on the LAWN . . . . . 8 I

CHAPTER XI

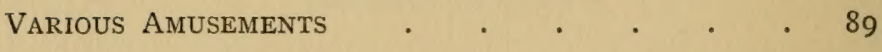

CHAPTER XII

Pussies in the Garden . . . . . . 98 


\section{LIST OF ILLUSTRATIONS}

PAGE

Tabby .

Frontispiece

The Good Place for Gudgeons

Where the Beer-cooler was launched

The Mill-pond from the Mill . 6

The Play-House . . . . . . . . 7

Plan of Play-House and Garden . . . . . Io

The old Play-House . . . . . . . I I

Mustard and Cress . . . . . . . 15

Two Little Washerwomen . . . . . . 22

Hanging out Dollies' Wash . . . . . . 23

Hairy Bitter Cress . . . . . . . 25

Hairy Bitter Cress . . . . . . 26

Hairy Bitter Cress . . . . . . . 27

Dandelion . . . . . . . 28

Dock . . . . . . . . . 29

Among the Big Lilies . . . . . . 30

The Great Pumpkin . . . . . . 3I

Broad Bean . . . . . . . . . $3 I$

Gourd Seed . . . . . . . . . 31

Seed of Hawkweed $\quad . \quad+\quad . \quad \cdot \quad \cdot \quad \cdot \quad \cdot 33$

Seed of Clematis montana $\quad \cdot \quad \cdot \quad \cdot \quad \cdot \quad \cdot \quad \cdot 33$

Seed of Scotch Fir a $\quad$. $\quad$. $\quad$. $\quad . \quad$. 34

Pricking out Seedlings . . . . . . . 38

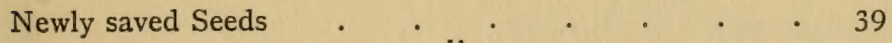


China Asters in Seed-Leaf . . . . . . 39

Incarvillea Seedlings . . . . . . . 40

Seed-Pod of Bell-Flower . . . . . . $4 \mathrm{I}$

Seed-Pod of Honesty . . . . . . . . 42

Snapdragon-Pod as Old Woman . . . . . 42

Love-in-a-Mist . . . . . . . . 42

Devil-in-a-Bush . . . . . . . . 43

How a Cowslip Ball is made . $\quad$. . . 44

Making a Primrose Ball $\quad$. $\quad$. $\quad$. . . . 44

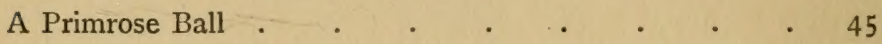

May-day Trophy . . . . . . . . 45

Morell . . . . . . . . . . 48

Kalmia $. \quad . \quad . \quad . \quad . \quad . \quad . \quad . \quad 53$

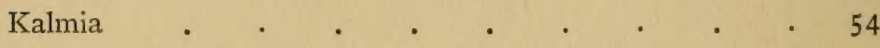

A Delphinium Freak . $\quad . \quad$. $\quad . \quad$. 55

Primrose with leafy Calyx . . . . . . 56

Deformed Pears . . . . . . . 57

Pea Flowers and Pods . . . . . . . 58

Bell-Flowers . . . . . . . . 59

Umbelliferous Flowers . . . . . . . 62

Cruciferous Flowers . . . . . . . . 63

Jean and Ann . . . . . . . . . 64

White Foxgloves . . . . . . . . 65

Plan. My Sister's Garden and Mine . . . . 66

Male Fern in the Cool Hedge . . . . . 67

Hard-head . . . . . . . 68

Hard-heads . . . . . . . . . 68

Edgings of White Pinks . . . . . . 69

The Seat . . . . . . . . . 69

Wheelbarrow good to sit in . . . . 70

My best Snapdragon . . . . . . . $7 \mathrm{I}$

Elevation, etc., of some Common Things. . . . 71

How to make a Right Angle . . . . . 74 


\section{LIST OF ILLUSTRATIONS}

In the Big Weeding Basket.

Watering Garden Borders . . . . . . 75

The Builder's Square . . . . . . . 75

The Garland Rose . . . . . . . . 76

Spring Flowers . . . . . . . . 77

Canterbury Bells . . . . . . . . 78

Thrift in Pavement . . . . . . . . 79

Reef Knot and Granny . . . . . . . . 80

Snapdragons . . . . . . . . . . 80

Small Bell-Flowers in Steps . . . . . . $8 \mathrm{I}$

Hedgehog half untucked . . . . . . $\quad$. 82

Hedgehog on the Lawn . . . . . . . 83

The Bat . . . . . . . . . . 84

Scarlet Toadstools . . . . . . . . . 85

Chantarelle . . . . . . . . . . 85

The Owl's House . . . . . . . . 86

Hedgehog out for an Evening Prowl . . . . 86

"It's a prickly job" . . . . . . . . . 87

Stalactites . . . . . . . . . . 88

The proper Place for Shoes and Stockings . . . 89

The Sand-House . . . . . . . . 90

In the Sand-Pit . . . . . . . . . 90

The Sand-Pit . . . . . . . . 9 I

Gathering Fir-Cones . . . . . . . 9 I

Fern Pegs . . . . . . . . . . . 92

"There are two more Cones" . . . . . . 92

Raking out Baked Potatoes . . . . . . 93

The Tea-Kitchen . . . . . . . . 94

Dabbling Toes in the Tank . . . . . . 95

The Tea-Kitchen . . . . . . . . 95

Just out of the Tank . . . . . . . . . 96

The Artesian Well . . . . . . . 97

Tabby in the Basket . . . . . . . . 98 
Tabby takes possession .

Tabby in the Cerastium.

Tabby .

Blackie and the Catmint

Tabby in the Catmint

Tabby in the Catmint

Tabby and the Photograph Basket .

Still more comfortable

Tittlebat

Tittlebat

Tavy

Pinkie .

Pinkie: Two Elevations

Two Little Waifs

Dorothea and Dinah

Three Kittens-Plan

Five Kittens-Plan

Four Kittens-Plan

Three Kittens-Plan 


CHILDREN AND GARDENS 




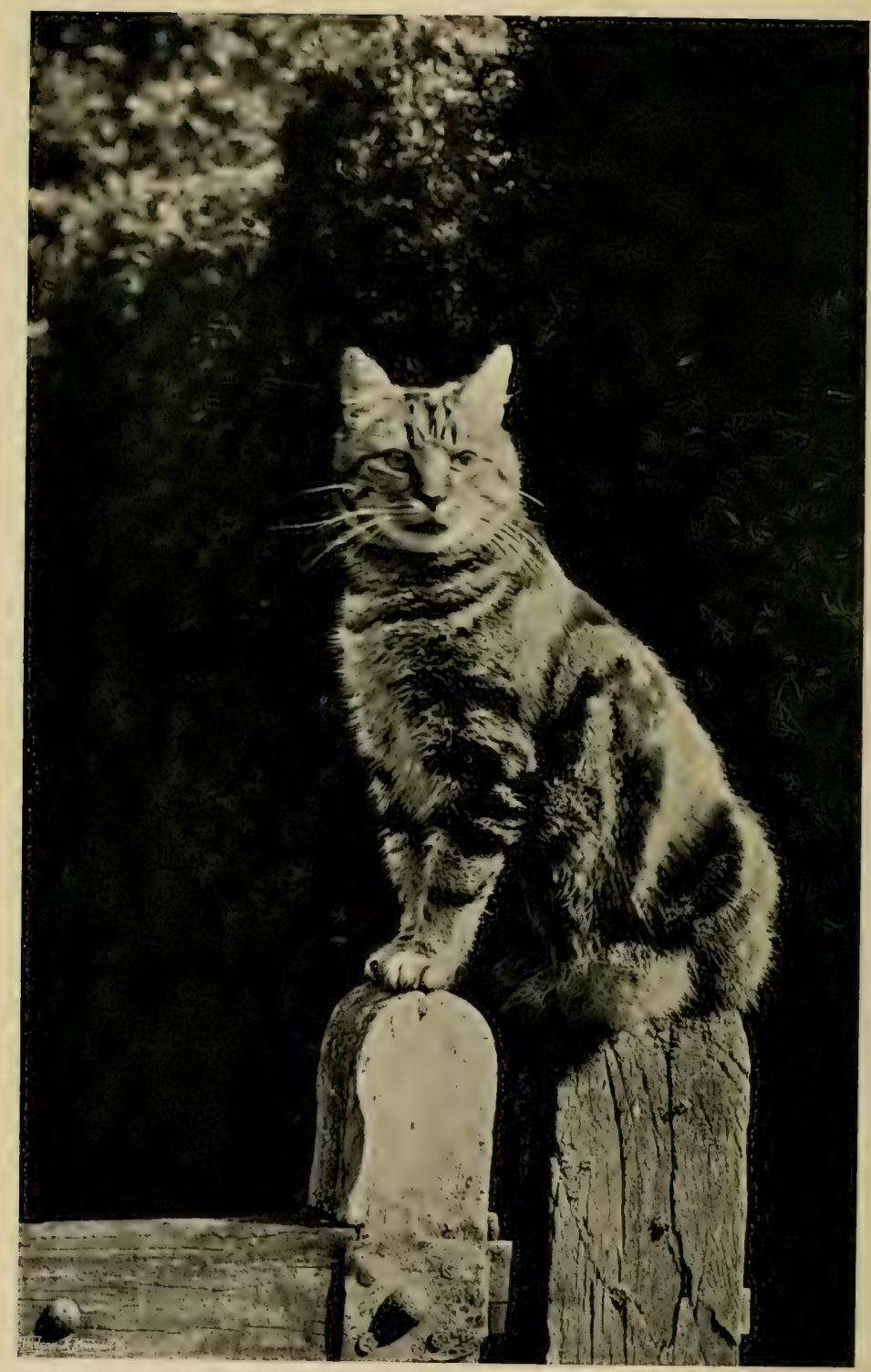

$T A B B Y$. 


\title{
CHILDREN AND GARDENS
}

\author{
CHAPTER I \\ MY OWN YOUNG DAYS
}

WELL do I remember the time when I thought there were two kinds of people in the world-children and grown-ups, -and that the world really belonged to the children. And I think it is because I have been more or less a gardener all my life that I still feel like a child in many ways, although from the number of years I have lived I ought to know that I am quite an old woman. But I can still-when no one is lookingclimb over a five-barred gate or jump a ditch; but then I was always strong and active in my limbs, and in many ways more like a boy than a girl. This was no doubt because my place in the family came in the middle of four boys; two brothers older and two younger. I had no girl companions, for my only sister was seven years older, so that we were not much together. It was therefore natural that I should be more of a boy than a girl in my ideas and activities, delighting to go up trees, and to play cricket, and take wasps' nests after dark, and do dreadful deeds with gunpowder and all the boy sort of things. 
But when my brothers went to school I had to find my own amusements. There was a dear old pony Toby and the dog Crim, and we three used to wander away into the woods and heaths and along all the little lanes and by-paths of our beautiful country.

Soon I came to notice the wild flowers and wanted to know about them; but had no one to tell me till I was given a capital book that you will hear about presently; but I had got to know them as friends long before I could find out what their names were.

The old home, not very far from where I live now, had biggish spaces of garden and shrubbery and two ponds-one a large mill-pond covering some acres; and three streams, so that I was always watching the ways of water. Where one quick-running stream, after tumbling down in a cascade, ran into the mill-pond, was a grand place for gudgeons. We used to catch them both with a rod and with a round dip-net, and sometimes had them fried for tea. This pond had a large island near the upper end, but no bridge. In our earlier years we had no boat, but belonging to the house was a set of brewing tackle, and among its items a beer-cooler. This is a wooden thing about five feet long and three feet wide, with sides eight or ten inches high, like a large shallow box or tray. My father had this taken down on the pond for something that was to be done near the pond edge, and we children surreptitiously used it as a boat to make perilous journeys over to the island. It was very naughty indeed - it was strictly forbidden, and was really dangerous, but mercifully we came to no harm. The 


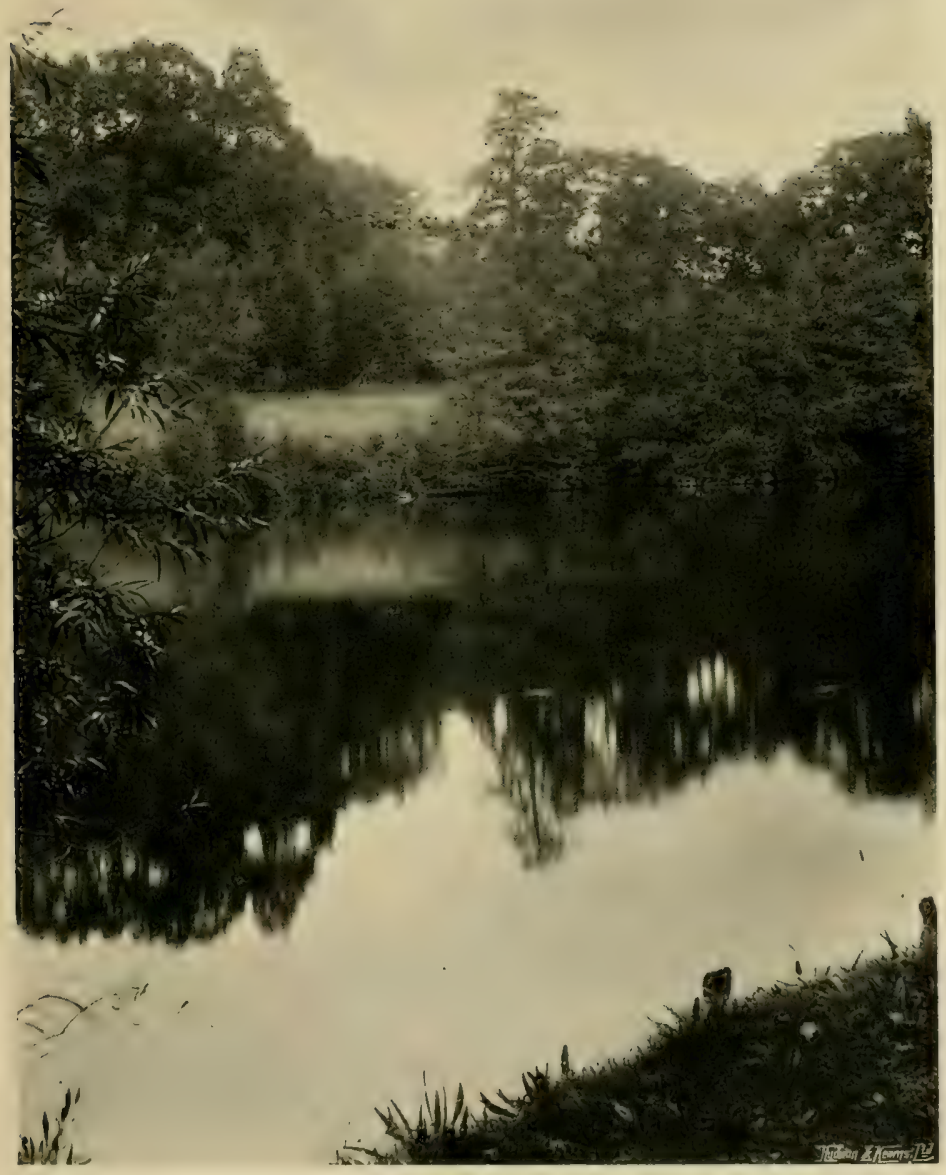

THE GOOD PLACE FOR GUDGEONS. 


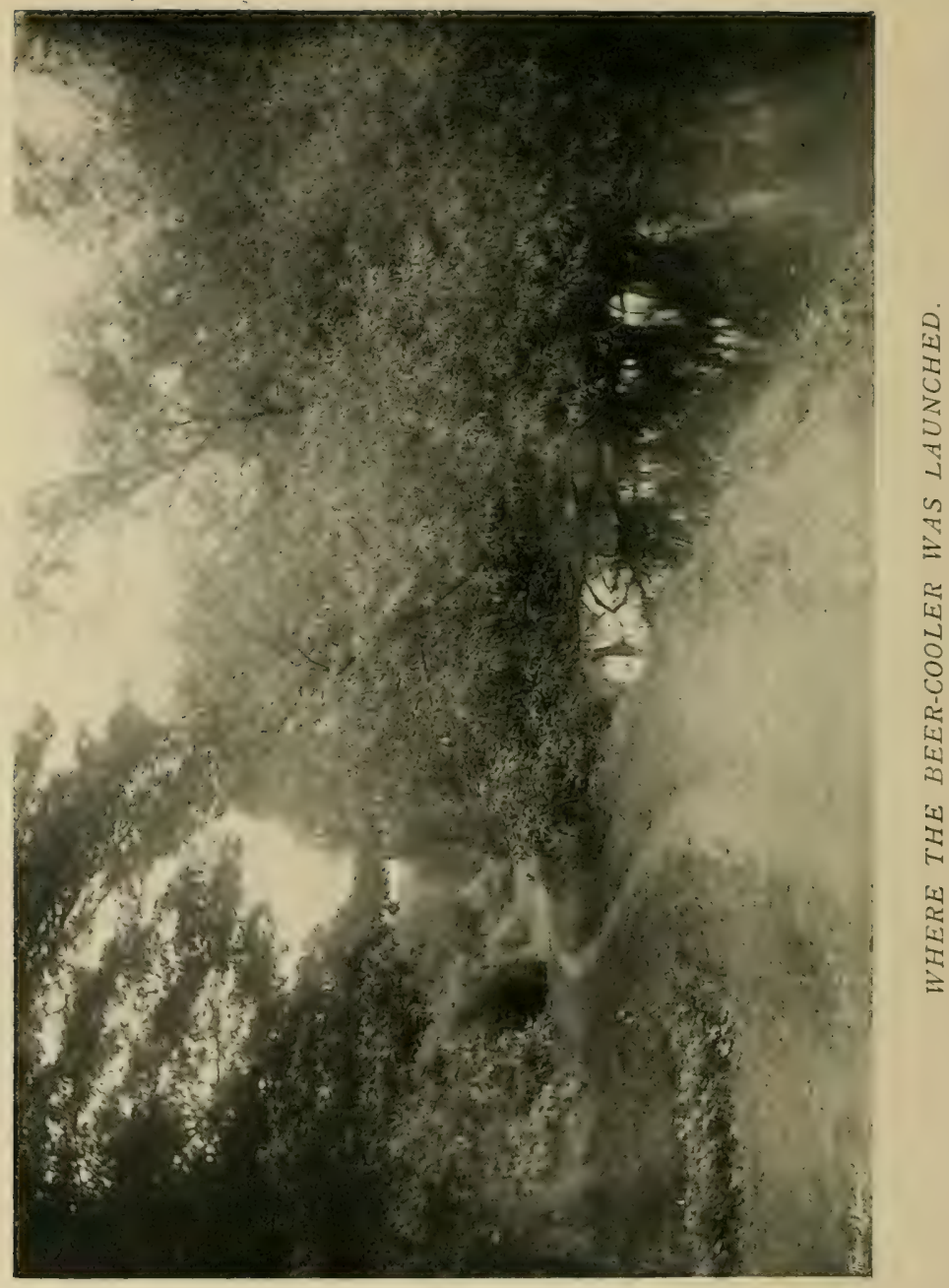


island was a sort of enchanted land. It had some great Poplars growing on it, and a tangle of undergrowth. Some of this came down and dipped into the water, and here the moor-hens built and brought out their broods of lovely little round black-velvet chicks. On the fringe of the island were the grandest Lady Ferns I have ever seen, and in its depths I first found the curious plant Twayblade.

Where another of the streams, a slower one, came into the pond, was a fringe of the beautiful Water Forget-me-not. I never can forget-how could I, when it is just as keen to this day - -my delight in the pure blue of this sweet little plant, with its clean-looking bright green leaves, and its faint scent that I used to think like the small quiet smell of the little wild Pansy that you find in cornfields among the stubble.

Just above the pond was a damp meadow, called the Nunnery Meadow, where there were quantities of the bright yellow Marsh Marigolds that flower in April. I remember the rather deep ditch that ran all along in the middle length of the meadow, and the bright red colour of the mud at the bottom, and a thin film of many colours that was always on the water. I was told that it was because there was much iron in the soil. Later in the year the meadow grew quantities of the pretty Ragged Robin and Meadowsweet and Marsh Orchis.

I was born in London: we came to live in the country when I was nearly five years old. Among the clearest of my recollections of London are some of grass and flowers. We lived in Grafton Street, close 
to Berkeley Square. When it was too hot to walk in the Green Park we borrowed the key at Gunter's and played in the Square garden. I remember a kind man at Gunter's, because with the key he always gave a nice goody; one of those oblong ones with pink or white sugar outside and an almond in. Later, my taste in goodies became less refined, because as soon as I came to know them, I thought that the best of all goodies were the vulgar peppermint bull's-eyes; and I think so still.

It was in the garden in Berkeley Square that I learnt to make a daisy-chain. I can still remember how difficult it was at first; how, when I had transfixed the stalk with the pin, the pin got restive and dragged the slit right out instead of stopping short of the free end of the stalk to leave the loop large enough to pass the stalk of the next Daisy through, but not large enough to let the head go through too. How well I remember the smell of the mown grass. To this day the scent of cut lawn grass is the smell of that Square garden. It was long before the days of mowing machines, and I remember seeing the man sweep up the grass that he had cut in the early morning. When short grass is cut with the scythe it is always done in the early morning, because when it is wet with dew it stands up better to the edge of the blade.

When we walked in the Green Park earlier in the year I was attracted by the Dandelions, and wanted to bring them home to the nursery. But our nurse, Marson, for some reason of her own, did not like Dandelions. She always said they were Nasty Things, 
and though I looked at them longingly and sometimes picked one to smell, I don't think I ever brought them home. But Dandelion also remains with me as a London smell, and one other growing thing-the little flowering grass that botanists call Poa annua, of which there is a great deal in the London parks and gardens. These are quite the brightest of my London recollections. Of people, besides Marson, I remember a nursery-maid Letitia, and a tall footman called George, and the butler Poulter, and Mdlle. Bichet, my sister's French governess. I take them in the sequence in which they concerned me. There was a small room next to the entrance hall that was the schoolroom, looking to the street. Sometimes I was allowed to go in to see the carriage at the door. Sixty years ago carriages were grand things, well worth looking at. It was a yellow chariot hung high on great C-springs, and the coachman was a glorious object in silk stockings and a powdered wig, with his seat draped with the imposing hammer-cloth; for in those days a certain amount of state was observed, and servants wore full-dress liveries in the afternoon.

When we moved to the country the yellow chariot -always called "charrot"-went into the depths of the big coach-house, and was never used again till my sister came out, when post-horses were harnessed to it for her to be taken to balls.

The shrubberies of the old country home had been very well planted, so that from early years I was familiar with a number of the best shrubs and garden trees. There were several kinds of Magnolia, and 
Ailanthus and Hickory, the pretty cut-leaved Beech and the feathery deciduous Cypress. Then there were Rhododendrons, mostly the purple ponticum, and the sweet Azalea pontica, and Kalmias and bush Andromedas and Buttercup Bush. And there were Ayrshire Roses and Cinnamon Roses and Rosa lucida, and the sweet Moss Roses, but hardly any herbaceous plants. These in fact were so few, that I remember with special adoration one tuft of the large blue Cornflower. This and a spreading patch of broad-leaved Saxifrage were the only interesting plants in a rather large extent of shrubbery-though there were a certain number in the borders of the kitchen garden that was some way from the house. 


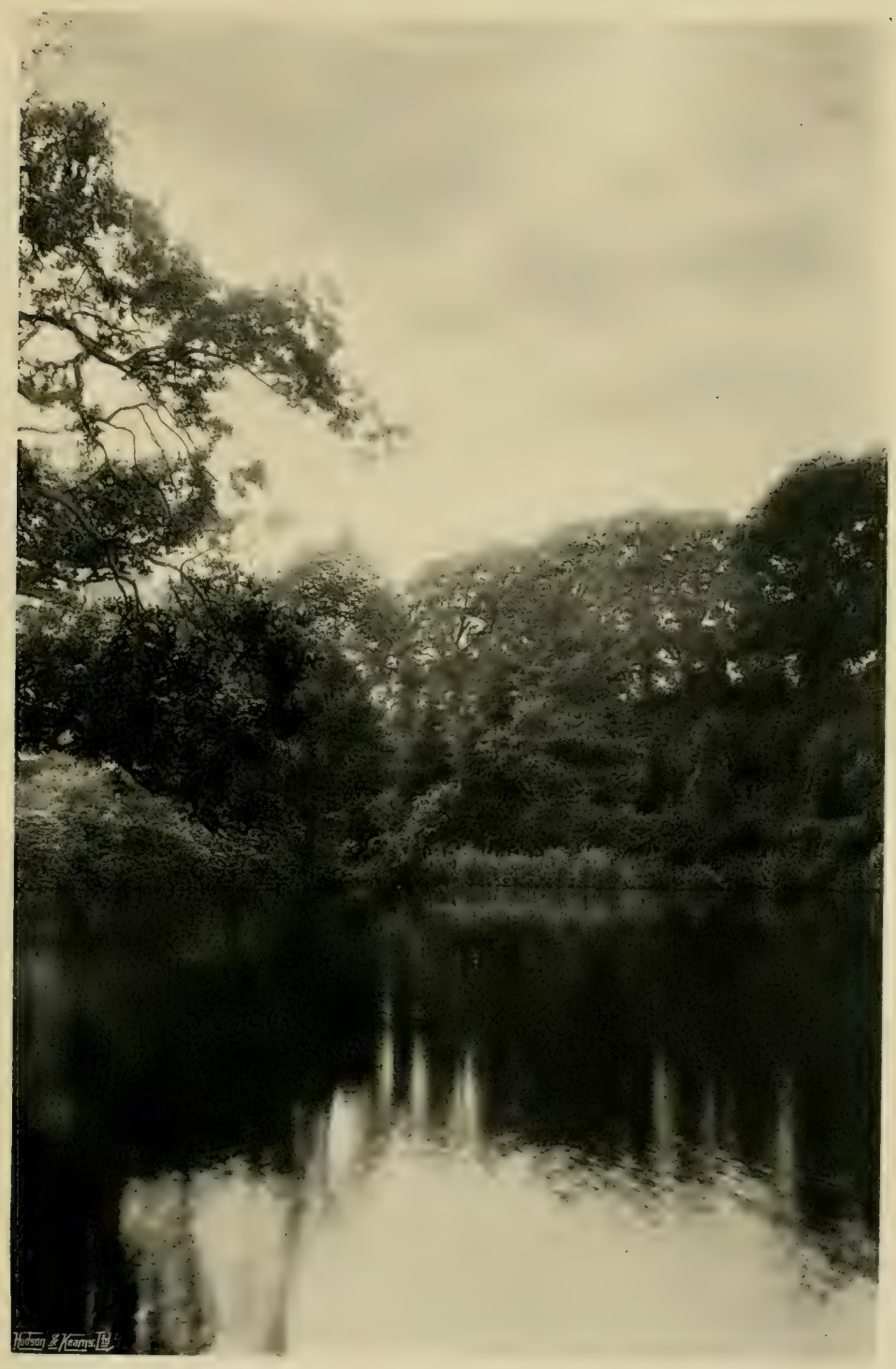

THE MILL POND FROM THE MILL. 


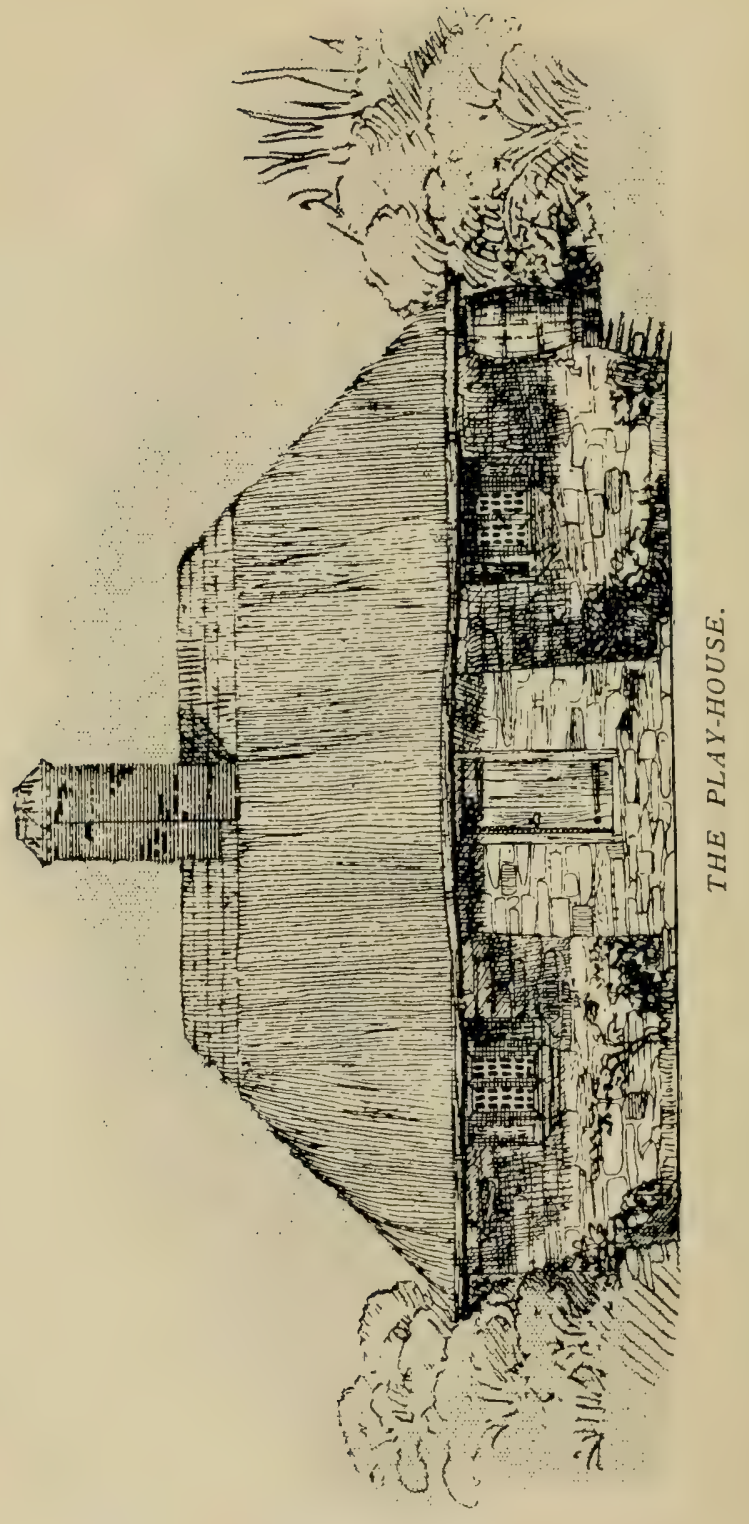


THE CHILDREN'S GARDENS AND THE PLAY-HOUSE

THERE is so much in this chapter that must be decided by your fathers and mothers that you must ask them to read it and to give it their most kind and careful consideration; for it is they who are to decide whether a suitable space of garden ground is to be devoted to the children's use, and in what state it is to be given over to their keeping.

It is not at all an uncommon thing to find children's gardens in some unattractive, out-of-the-way corner, or, most commonly of all, under or too near trees, whose roots invade the space and render it a place that would be difficult to make anything of, even for persons of long experience. It is neither fair nor reasonable to give a child who wishes for a garden a place that is full of difficulties. I even think it is better that the children should not have to make their gardens at all from the beginning, unless any enterprising individual specially wishes to do so.

A child will naturally answer a leading question in the obvious way. If an elder asks, in a tone meant to appeal to pride and self-respect, "Wouldn't you 
like to make and plant your own garden, and do it all yourself?" the answer will probably be "Yes," but show him two spaces of garden ground, one a charming little flowery place and the other a blank, and then ask which he would rather have; can there be any doubt about the answer?

The fact is that the good planning and making of ever so simple and small a garden wants most of the qualities, the knowledge, and the technical ability that go to the making of a large one, and I think that to help children in the best way to love and value a garden is to give them a pretty one ready made. The actual planting, though it must be learnt in time, would seem to come better a little later. The daily tending of an already made garden is better to begin with; it is more interesting and inspiring, and the needs of the flowers can be seen and attended to with immediate result. It is in every way more delightful and encouraging to a child to have the lovely flowers to tend at once than to have to flounder through a mass of failure and mistake, and then to wait the best part of a year before there is anything whatever to be seen. The time will come soon enough when some plants will have to be taken up for dividing and replanting, and then this replanting will come as an interesting incident and a new bit of practical work.

Before having the care of a garden of their own the children should be taught to use their tools. There is always some vacant plot in the kitchen garden where they can practise, under careful teaching, the three most important manual operations-digging, hoeing, 
and raking. If one of the elders of the family is a practical gardener, and will give some good lessons in the use of tools and the care of tools, it is much better than that the children should be left to pick it up by themselves on those occasions only when the use of the tools is wanted in their own gardens. A good straight bit of digging in clear ground for half an hour at a time will soon train the young hands and arms and backs; so it is also with hoeing and raking. Raking wants a good deal of practice, it is quite difficult at first; the rake wants to stick its teeth into the ground. It needs some dexterity to bring the tool back with the light level stroke that does the work, whether of levelling dug ground or of collecting stones or bits of stick and rubbish, or whatever it may be. It would be useless in a book to attempt to teach these operations, because, like all tool work, to be shown how to do it is worth volumes of description. The thing concerning it most useful to print is to advise the beginner to get into the way of using rake, hoe, and broom quite equally with both hands. It not only helps general dexterity and convenience, but it is much less tiring to work a bit with right hand up and left hand down, and then to change hands and work the other way. This does not apply to the spade, which is always used one way.

It is important that the children should be provided with proper tools. I much doubt whether good small tools can be bought ready made. What are kept in ironmongers' shops as "ladies' tools," with varnished handles and blue blades, and that are usually given to children, are wretched things,--badly shaped, badly 
balanced, and generally weak where they should be strongest. The tools should be made by a clever country blacksmith, and the handles carefully adapted to the use of the little hands; perfectly smooth but not varnished. The smallest size of the well-made steel rakes that are sold ready-made will do, but the handle will have to be replaced by a thinner, lighter one.

The necessary tools are spade, rake, hoe, a little wooden trug-basket, and a blunt weeding-knife; a good cutting-knife, a trowel, a hand-fork, and a little barrow. There will also be wanted some raffia for tying, some hazel sticks, and a little white paint. A tiny tool-shed, with a well-lighted fixed bench, is most desirable, the tools hanging in their proper places on the wall. Tools should never be put away dirty. A little wooden implement, that any child can whittle for himself, should be kept on the bench for scraping off any earth that sticks to spade or trowel. The gardener will show you how to make it. A birch broom will also be wanted.

The late summer or early autumn is the time to begin the little gardens. The ground should be got ready not later than September, so that it will have time to settle before it is planted. Every detail should be exactly thought out beforehand, in order that, by the end of October or beginning of November, the plants may be put in their places. The children can be learning all the time. They should watch the whole operation and ask questions, and be told why everything is done.

Then, when in early spring the tips of the plants are pushing above ground and the Snowdrops are 


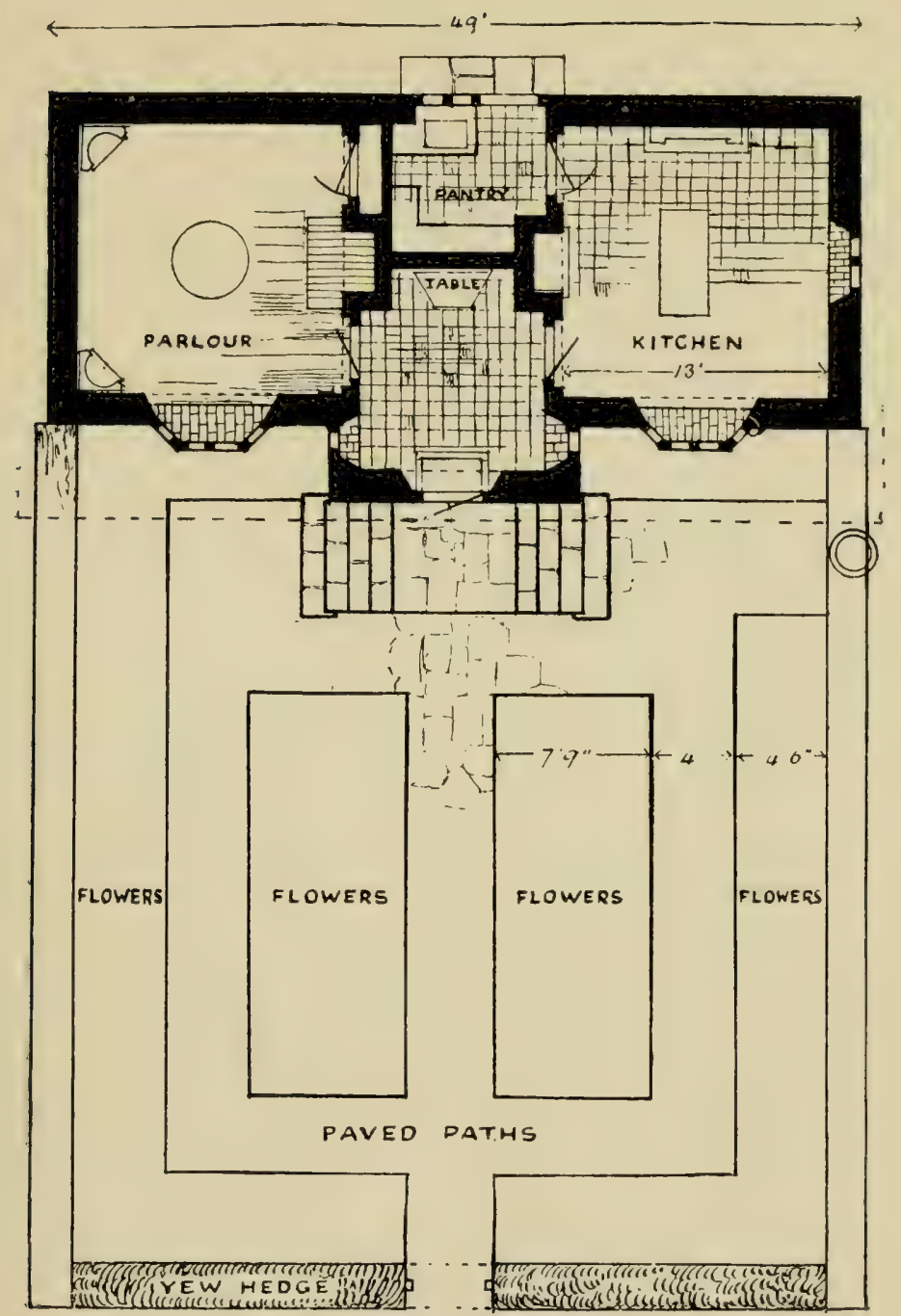

PLAN OF A PLAY-HOUSE AND GARDEN. 


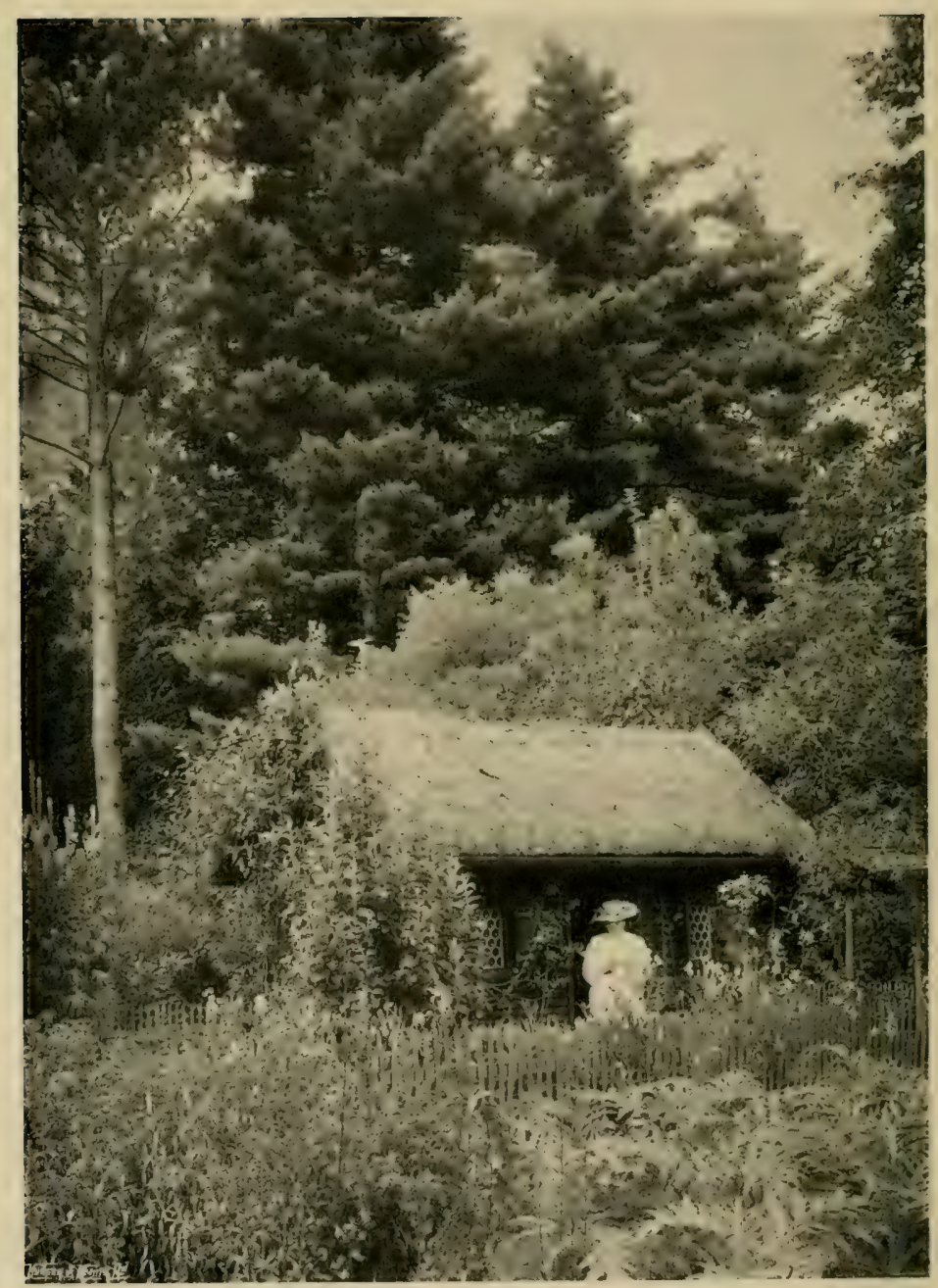

THE OLD PLAY-HOUSE. 
showing their little white buds, the year's work will be beginning. The experienced elder should keep a close watch on the little gardens and their owners, and, week by week, should teach and show what is to be done. Weeding will be the first thing, and the little trugs will come out and the blunt weeding-knives to save fingers, and so on throughout the year.

It will have to be considered, in cases where there are two or three children, whether it is better to have a separate garden for each, or whether they shall have one garden in common. The pleasure of individual possession is so great among children that, if they are offered their own choice, they will, in their own unthinking way, be most likely to say they would like separate gardens. But they should understand that in this way it is very difficult to make anything pretty of it, whereas in a garden all together it may be made extremely pretty. They have also to remember that now and then one of them may be ill or away on a visit, or a boy who loves his garden may be at school. In all such cases the garden with an individual owner gets neglected, while with the common ownership this does not happen, and all parts of the garden are equally attended to.

If the parents will give the children that greatest of delights, a real, well-built little house, with a kitchen and a parlour, where they can keep house and cook and receive their friends, the garden would naturally be close to it and form part of its scheme.

It must be confessed that a good play-house is a somewhat costly toy, but its value is so great, apart 
from the intense interest and delight that it is to the children, that it is well worth the consideration of parents whose means allow them to provide it.

It is a little house somewhere in garden or shrubland, consisting of a kitchen and a sitting-room. If it can have an enclosed porch so much the better. In the kitchen the children make and bake little scones and cakes, and serve them at the tea that is laid in the adjoining sitting-room, and learn the elements of even more serious cookery, such as jam-making and simple ways of cooking eggs, and any advance on these beginnings that their taste or capacity may seem to ask for. The little house would be provided with all necessary fittings - a cooking-stove in the kitchen, a dresser, a cupboard, and a stout little kitchen table with a drawer. If it can have a small pantry containing a water supply and a sink, where the crockery is washed up and water drawn, and a round towel handy, it will be better than if these necessaries were in the kitchen itself.

The sitting-room would also have a fireplace, for though the little house might not be used perhaps for three winter.months, yet by the time March comes, with its long bright afternoons, many would be the teas out at the play-house. The sitting-room would be appropriately fitted with two glass-fronted corner cupboards, to hold the tea things and glasses, for-who knows?perhaps there might be an occasional luncheon party on birthdays or other great occasions. There would also be a little narrow sideboard with shelves, that would hold things both for use and ornament, and drawers for 
table-cloths, spoons, and so on. A set of chairs would be ranged round the wall. These main pieces of furniture would be provided, but other niceties, even if not bought by the children themselves, should at least be made by them, so that they would make up window curtains, and hem and mark the table-cloths, dusters, and kitchen cloths.

The elders would often be invited to tea, and it would probably help matters if a specially praiseworthy culinary effort or other evidence of good housewifeliness suggested a little gift of money, to be expended on the perfecting of the play-house's equipment.

There are thousands of little girls in England, and small boys too, who would not only delight in working the play-house, but who would in after years visit it again with delight, and look back on its lessons of play-work with thankfulness, both for joyful memories and for the abiding usefulness of all that it had taught them.

The pretty lady in the picture is a German Princess. She has brought out her work to the old play-house, and is trying to think herself a child again, remembering all the happy hours she spent here a few years ago. The picture was done by my friend Miss Willmott, the greatest of living women-gardeners, and given me by her for your book.

The plan gives an idea of the accommodation required. The tiny cottage stands in a region where shrubbery gives place to woodland. In many places it might come conveniently at an angle of the kitchen garden wall, and would suggest the making of a pretty 
building, such as so often adorned the angles of wallenclosed spaces in the gardens of old. And where there are boys who would worthily use a workshop it might be combined under the same roof, but with a separate entrance.

The sense of possession is keenly enjoyed by children; their own garden, their own little house! They would have a pleasant pride in showing it all, pretty and useful, and well kept; it would also be delightful to think of the many things they could make for it. These would all be sources of keen interest and enjoyment, and of encouragement for the inventiveness and ingenuity of busy little brains and fingers.

Then there would be the combined use of house and garden; for the garden should have one little vegetable strip, perhaps behind, that would provide the tea-table with Radishes and Lettuce and Mustard and Cress, while the flower garden would give a little bunch of flowers on the tea-table and perhaps another for the window-board. It would be best if the little garden was held in common, rather than be, as is more usual, cut up into separate sections for each child; for as a whole it could be made much prettier, and would better maintain its relation to the play-house, while all the young hands would have plenty of scope for work for the supplying of its many needs.

It is very nice to grow Mustard and Cress in the letters of one's name. You prepare a little long-shaped bed, and stretch two strings with wooden pegs at their ends about eight inches apart. Between these strings you scratch out the shallowest possible hollow, an inch 
wide, in the shape of the letters. It looks more finished if you have a border all round. You can make the sowing-place for the border by laying down the handle of a rake before you take up the strings that were your guide for the height of the letters. You just press on the lying-down rake handle, and it leaves a little shallow trough, just right for sowing the seeds in. Then you barely cover the seeds with earth and wait till they come up. I advise leaving the strings while you are

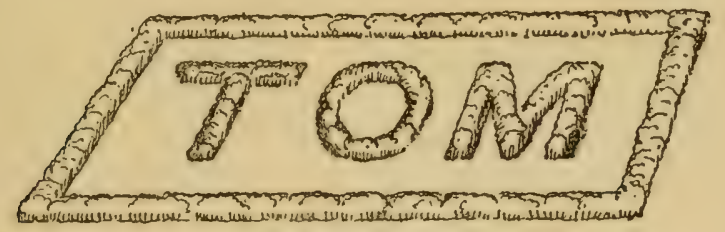

MUSTARD AND CRESS.

doing the border, because you can either measure from them to the ends of the rake handle, so as to get a nice parallel line, or at least you can look at them and get it right by your eye.

For Lettuces you must watch the gardener some day when he is planting them. Then, when you want to plant them in your own garden, you must look out for a time when the ground is damp (but not soaking) after rain, or some day when there is a soft drizzle going on, and you ask the gardener for some young Lettuce plants and plant them with a dibble as you have seen him do. You will see that there are two kinds of Lettuces-Cos Lettuces, with rather smooth leaves, which stand upright, and Cabbage Lettuces, that have blobby wrinkled leaves that fold over and make low 
dumpy plants. When the Cos kind are within a few days of being the right size to cut they have to be tied up to blanch, as it is called, that is, to make them white and tender.

When you have a lunch at the play-house you will want a nice salad, so I will tell you the right way to make it. Your Lettuces must be perfectly clean and quite dry. Sometimes they are clean as they grow, and do not want washing, but if they are dusty or in any way not quite clean, they must be washed in plenty of perfectly fresh water and then dried, first by swishing the whole Lettuce about in the open to get rid of most of the wet, and then by separating the leaves and putting them in a clean cloth. Then you cut or tear the leaves to pieces into your salad-bowl. You must have ready on a plate three little heaps of chopped herbs-Tarragon, Chervil, and some kind of Onion, chopped very small, or the tops of Chives; a level teaspoonful of Tarragon, a heaped tea-spoonful of Chervil, and a not quite full spoonful of chopped Onion. Now you want oil and vinegar, pepper, salt, and pounded sugar. You measure into a table-spoon one spoonful of oil-it must be the best possible oil, not at all easy to get in England, but your home people will see to that-and you pour the oil over the Lettuce in the bowl, and turn it well over, so that every bit of leaf has a coating of oil. Then you put into the spoon a heaped salt-spoonful of sugar, a level salt-spoonful of salt, and two or three shakes of pepper; you half fill the spoon with vinegar and half with water. Then you mix this all together in the spoon, pour it over the salad, and 
turn it well over so that it is all mixed. Then you put in the chopped herbs, give it another mixing, and you have a delicious French salad. Some people like the seasoning of herbs to be either Tarragon and Chervil or Onion, not both together. I like them all together.

You should have these herbs in your little kitchen garden. Tarragon is a perennial plant that comes from a warmer country, and likes the warmest place you can give it. Chervil is an annual ; to have a nice supply you should sow it two or three times a year. You will soon be able to keep your own seed, and can keep on sowing little patches here and there. It is of a nice fresh green colour, grows easily, and looks well anywhere. Chives is a kind of small onion; it is planted in tufts. You could have a row of tufts as a bit of your kitchen-garden edging; it is often grown like this in cottage gardens. When you want Chives for salad you just go out and cut what you want off the growing plant. I think you should have a little supply of Parsley too. You sow it where it is to be; it also makes a good neat edging. You will want it for decorating cold dishes for lunch, and for soups, and other cookery when you learn to do it.

Now I will tell you how to make some very nice play-house soups. First the true French Julienne and then some milk soups. They want no meat-only vegetables, and they are nicest done in those capital French earthenware pots that are called "marmites"; you can get them anywhere now. Years ago I used to make them in pipkins, which are very much the same sort of thing. 
Julienne.-2 oz. butter, a small onion, I lettuce, I large carrot, I small turnip, 3 sprigs of parsley. Melt the butter in the bottom of the pot; slice the onion, after cutting it nearly through across and across. Put it in the butter and keep moving it about to prevent the onion catching on the bottom of the pot and burning. It should cook for ten minutes to a medium brown colour. It must not be dark brown or at all burnt. Then cut the lettuce into shreds and put it in the pot. It soon melts down, for it is a succulent or juicy thing, nearly all water. Then you add the carrot and turnip. You cut them into what are called Julienne strips, and the way to do it is this. The outer part of the carrot only is used-the nice red part. The paler yellowish inside of a full-grown carrot is tougher and more tasteless. You cut the raw carrot across into bits a little less than an inch long. Then you take one bit at a time, and with the knife held the long way of the carrot, you pare off the red part round and round till you come to the yellow core. It is as if you were cutting the outside of a cork to make it smaller. You do this with all the pieces, and then flatten them out and lay two or three one over the other, fitting them together as nicely as you can. Then you cut neat little strips, cutting through all the layers, and you have your Julienne strips. The turnip you square a little at the outside edges and slice one-eighth of an inch thick, fit the slices together again and cut once across the middle. Then turn it the other way and cut your little strips. Everything in cooking must be done very carefully, very exactly, and in perfectly clean 
ways. Add your carrot and turnip strips to what is already in the pot, which will look like a sort of vegetable mash at the bottom, and then put in one and a half pint of hot water. You must now arrange your pot and fire so that it goes on cooking for quite an hour. About ten minutes before it is done you chop the parsley and put it in ; if you add it earlier the flavour will be lost. Remember in using chopped parsley that the stalks are as good as the leaves; in fact they really give the best flavour, though the bits of leaf look nicest.

Bonne Femme Soup.-This is a milk soup, and is more quickly made. Begin as before with the onion and butter, but stop the cooking of the onion before it gets brown; it must not be deeper than pale yellow. Have ready half a large lettuce and an equal quantity of the broad-leaved sorrel. Remember that the sorrel has a strong acid juice that is rather unwholesome. You have to get rid of most of this by what is called blanching. Note that there is a blanching in cookery and a blanching in vegetable growing, and that they mean different things. Blanching in gardening means making the hearts of plants white by tying them up, as you do Cos Lettuces, or covering them with a bank of earth, as in the case of celery and some other salad plants. Cabbages and Cabbage Lettuces blanch their own insides themselves by folding their top leaves over. Any plants get blanched or whitened by having the light kept from them when they are in a growing state. Blanching (from the French blanchir), according to the true meaning of the word, ought always to mean making 
white. In some cases in cooking it does mean this, as in blanching almonds, when by putting them for a minute in boiling water the brown skin is loosened and the white almond is easily taken out. I think the word as used in cooking must have come from this, only that instead of the meaning of the word being that the thing blanched is made white, it has come to mean that the thing is put for a minute or two in boiling water, for this is what blanching now means in cookery.

So to get rid of the harmful acid in the sorrel it is blanched in boiling water. Two or three minutes is enough. It is then cut into shreds, and the lettuce also, and both are added to the slightly frizzled onion, and it is all stewed together for a quarter of an hour. Then you add a pint of water and let it cook another quarter of an hour. Near the end I like to add two teaspoonfuls of white sugar and three teaspoonfuls of salt. Then you pour it into the tureen, wait a minute, and then add to it in the tureen half a pint of milk that has been slightly warmed. You cannot add the milk to the boiling soup, or it would curdle.

Potato Milk Soup.-For this I generally use some spare potatoes that have been boiled. You begin just the same way with the butter and onion, and when the onion is done enough-you should do it as much as you can without its turning colour; it should be only the very palest yellow, not the least brown-you add a very little hot water (about a wineglassful) and the potatoes, cut up into bits the size of a lump of sugar. Then add what will make up a pint of water in all, and let it cook for a quarter of an hour. Put in some 
sugar and salt, as in the last recipe, pour into the tureen, let it cool the least thing, and then put in the half-pint of warmed milk as before. Some of the potato will have gone into a purée (thinnish sludge), and some of it remains in soft knobs. This is the purke de pomme de terre of smarter dinner-tables, but to make it all look smooth the cook passes it through a sieve. But I like it best the real French middle-class way, with the knobs of potato and shreds of onion left in.

Any of these soups, with some good cheese to come after (perhaps a cream cheese, which looks so nice laid on a vine-leaf), and the salad I have told you of, and perhaps a little fruit, is a dinner or supper fit for a king!

In colder weather it is nice to have toasted cheese. English cheddar is one of the best cheeses for toasting. You slice $4 \mathrm{oz}$. thin and put it in a shallow, flattish pan; add to it rather more than a tablespoonful of beer and a good teaspoonful of brown sugar. I don't know why brown sugar improves it, but it certainly does. You must have ready on a hot dish a nice piece of toast, cut rather thicker than ordinary toast, and the whole size of the loaf, with the crust cut off. As soon as the cheese is melted, and looks quite smooth and all alike, you pour it over the toast.

Scrambled eggs is another capital thing, and this is the best way to make it. Cooks generally spoil it and get rid of all the nice eggy taste by working it about too much in the bottom of a saucepan. You can make it in one of those nice clean round or oval French fireproof dishes with short ears, and you serve it in the 
dish it is cooked in. Melt a bit of butter in the dish, big enough to cover all the bottom when it is melted, add a good pinch of salt and a dust of white pepper. Break the eggs (two or three according to the size of the dish) on to the fizzling butter; have a silver fork in your hand and break up the eggs gently. Keep on moving it about with the fork, mostly with a lifting action, because this lets the uncooked egg run on to the hot dish where you have just raised what has already cooked and thickened. Directly it has all thickened, or even a moment before, take it off the fire, because you must remember that it goes on cooking in the hot dish. If you do it like this you will know what a good thing scrambled egg can be.

For tea, nothing is better than mustard and cress sandwiches, or watercress sandwiches, or sandwiches of the little weed cress I shall tell you about in the next chapter. But when you have invited your elders, or on any other important occasion, you should have some freshly-made scones, or some little cakes.

Scones. $-\frac{1}{2}$ lb. flour, 3 oz. butter, a pinch of salt, I dessertspoonful of baking-powder, I egg, 2 tablespoonfuls of milk. Mix the flour, salt and bakingpowder and rub in the butter. Beat the egg and milk together and pour to the rest. Mix it lightly with the blade of a knife, roll out on a floured board, half an inch thick, and either cut it into rounds with a $2 \frac{1}{4}$-inch cutter (a tin thing made on purpose), or cut it into triangles. Bake 5 to Io minutes, according to the heat of the oven. They are served split, buttered both sides and put together again. 


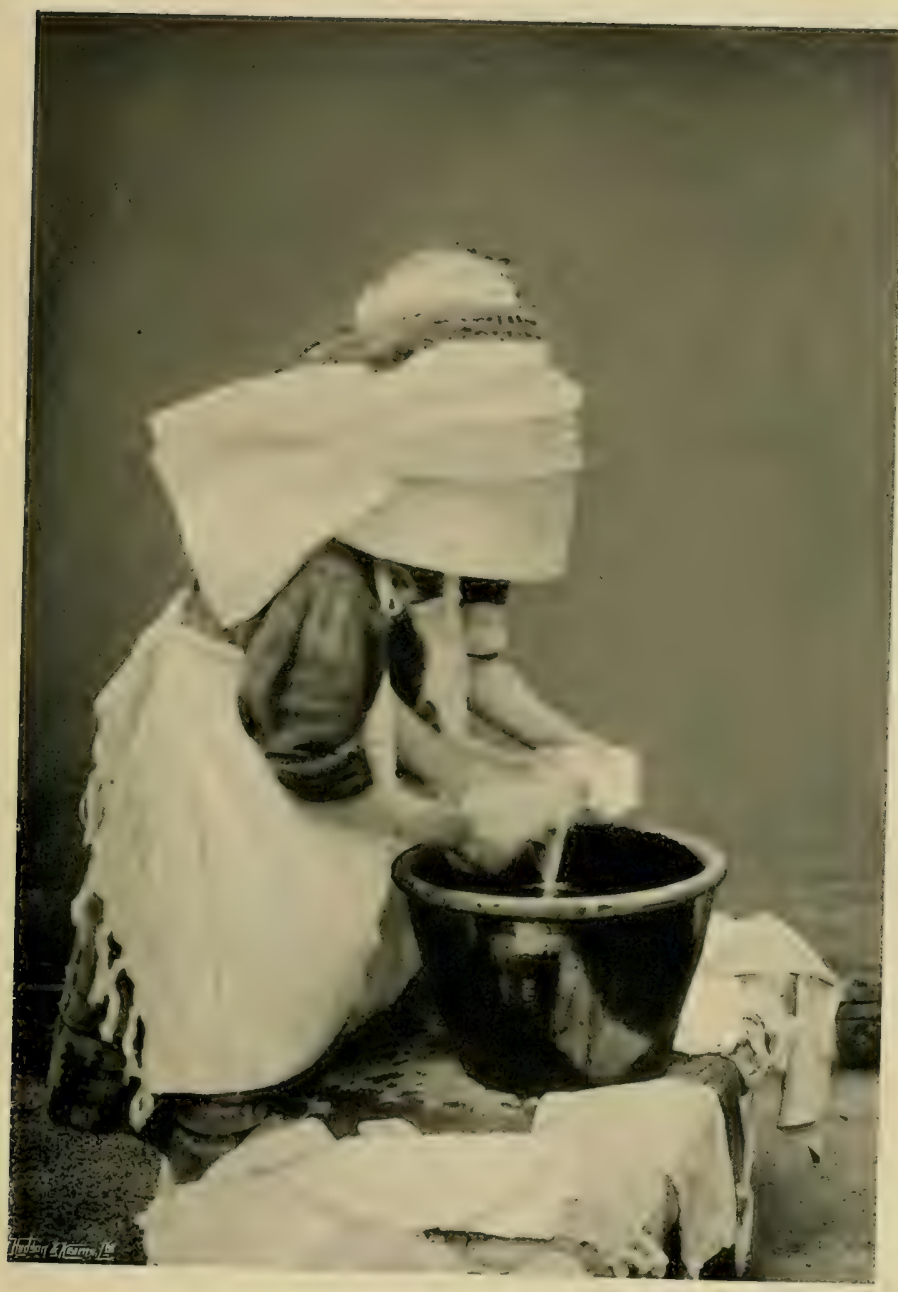

TWO LITTLE IVASHERWOMEN. 


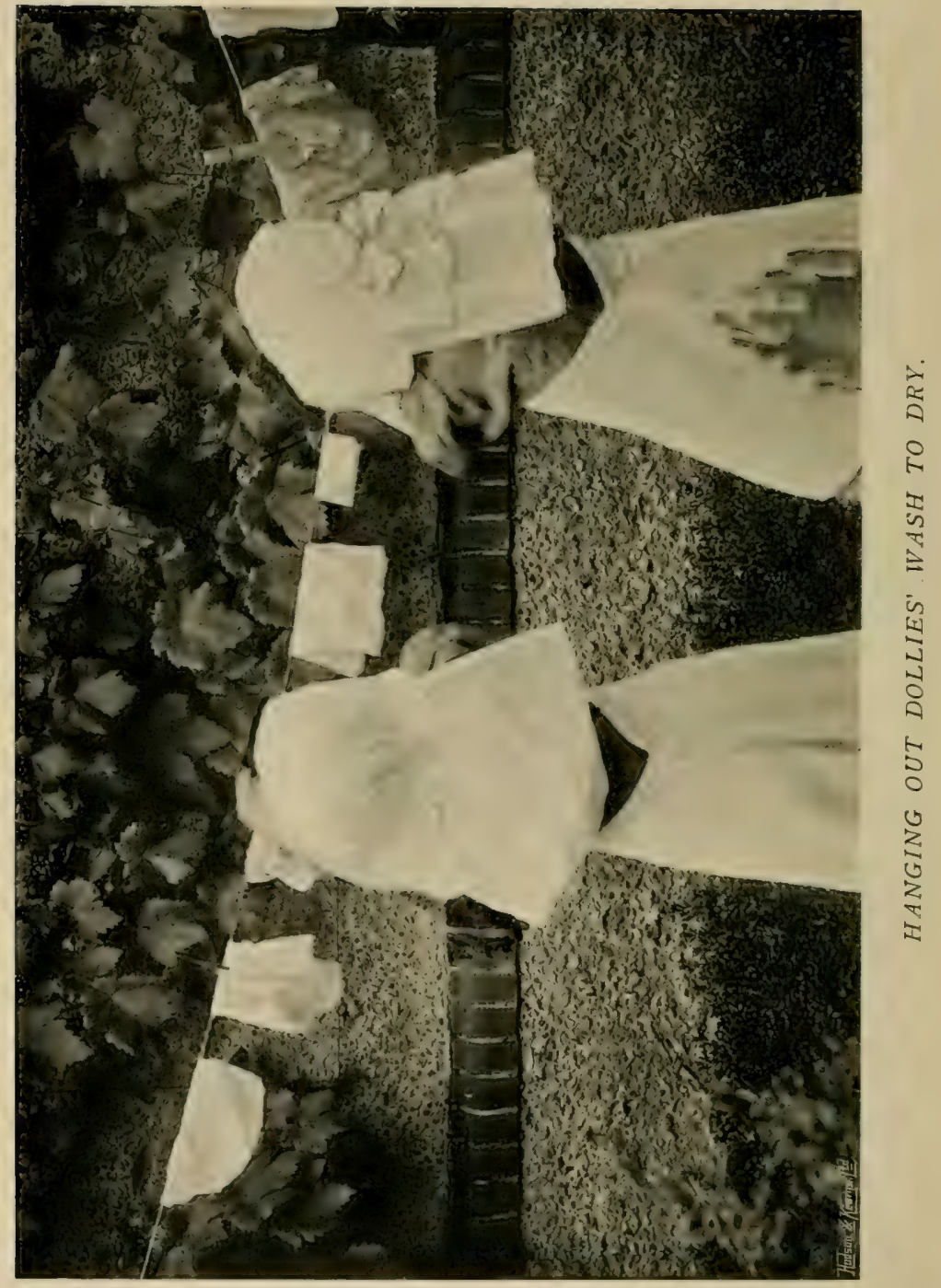


Fairy Cakes.- $\frac{1}{2}$ lb. flour, 4 oz. butter, a large teaspoonful of baking-powder, 4 oz. castor sugar, I egg, $4 \mathrm{oz}$. sultanas, or $2 \mathrm{oz}$. sultanas and $2 \mathrm{oz}$. currants. Mix the baking-powder with the flour and rub in the butter. Add the sugar and the dried fruit. Beat together the milk and egg and put to the rest. Mix lightly and put into shallow tins (the sort used for mince-pies) and bake in a quick oven 15 to 20 minutes.

In the play-house pantry, or better still, in summer weather somewhere near but out-of-doors, we wash the dollies' clothes. If the sun is very hot we put on our sun-bonnets, and we pin ourselves up in bath-towels so that no splash matters, and turn up our sleeves as high as they will go, and have out that nice red pan and wash all their things. Cotton, muslin and flannel; little frocks and petticoats and shimmies, and their tiny pocket-handkerchiefs, and hang them on the line to dry. 


\section{CHAPTER III}

\section{EARLY WEEDS}

By the time March comes you should look out for weeds. Of course you must learn to know your weeds, just as you must learn to know your flowers, and you must know them, too, in quite a young state. Like garden flowers, weeds are either annual, biennial, or perennial. The word "annual," applied to a plant, means one whose whole lifetime is begun and finished within one year. Biennial means one that grows one year and flowers the next, like Sweetwilliam and Foxglove and Canterbury Bell. Perennials are the plants that will go on for ever if they are divided every few years. Some are the better for being divided every year. These are the ones whose roots spread out quickly, like Michaelmas Daisies and some of the Sunflowers. Any of you who have learnt a little Latin will see from the word itself what annual, biennial, and perennial mean; and will see that the words themselves describe, as I have just done, the length of the plant's lifetime. Those who have not learnt Latin must take my word for it.

We generally sow annuals in March, to flower in 
middle and late summer, though most hardy annuals are stronger and better and bloom earlier if they can be sown in autumn. But there is a difficulty about autumn sowing, which means sowing in August and September, because just then gardens are filled with plants at their full growth; and, especially in your own little gardens, I should not expect you to be able to do it. But some day, when some pretty annual has shed its seed and come up by itself-some Poppy or Lovein-a-Mist, or whatever it may be, and you had left it at weeding-time, seeing that it was not one of the familiar weed seedlings, you will see what I mean about its unusual strength. This is the way plants sow themselves.

There are three troublesome weeds, one annual, the others perennial, that show quite early in spring. They are up in February, though, if you don't want to do much gardening in February, it will not matter if you don't look out for them till March. They are a little Cress, Dock, and Dandelion; we will take the Cress first. The little plants come up early and look neat and harmless. It is the Hairy Bitter Cress. The botanical name is Cardamine hirsuta - hirsuta means hairy. You think the plant is quite smooth; but if you look at the fullgrown leaf quite close you

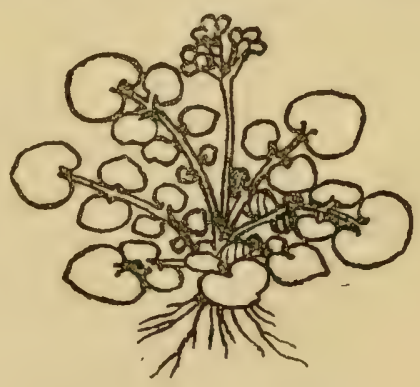

HAIRY BITTER CRESS. will see tiny hairs upon the surface and at the edges. When it is young it looks like this. 


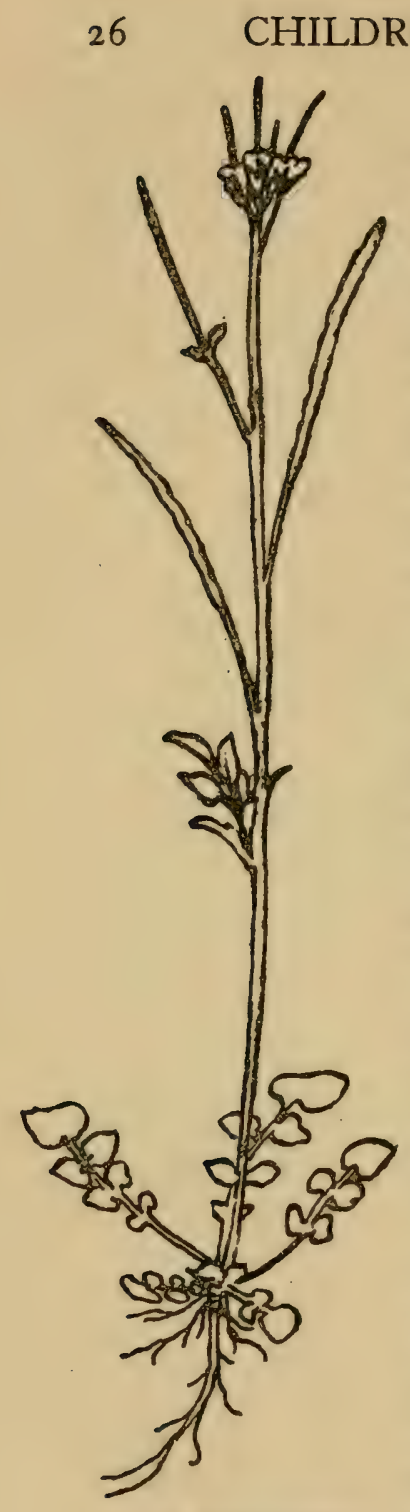

In March it comes into flower, and then is the time to look out for it, unless you have trained your eyes to see it sooner. But it shows up brightly when the little flower is out. You must not miss a single one, for this is what happens. Directly the flower is over the stem elongates; each seed-pod lengthens, and the little seeds inside swell and ripen. By this time the plant looks like this.

Then look out! for as soon as the seed is quite ripe, at the least touch the outer covering of the long pod curls itself up and acts like a catapult, scattering the seeds about quite a long way and filling the garden again with weed-seeds. And you must remember that this crafty little plant has a sly trick of turning a dark bronzy colour that makes it difficult to see. But if you are careful, and get hold of it when it is full-grown, but has not yet thrown up the flower-stem, you can have a glorious revenge. You know the old story of some savage tribes who kill and eat their enemies, and who believe that when they have swallowed some 
doughty warrior they become imbued with his best qualities. You can do the same with Cardamine

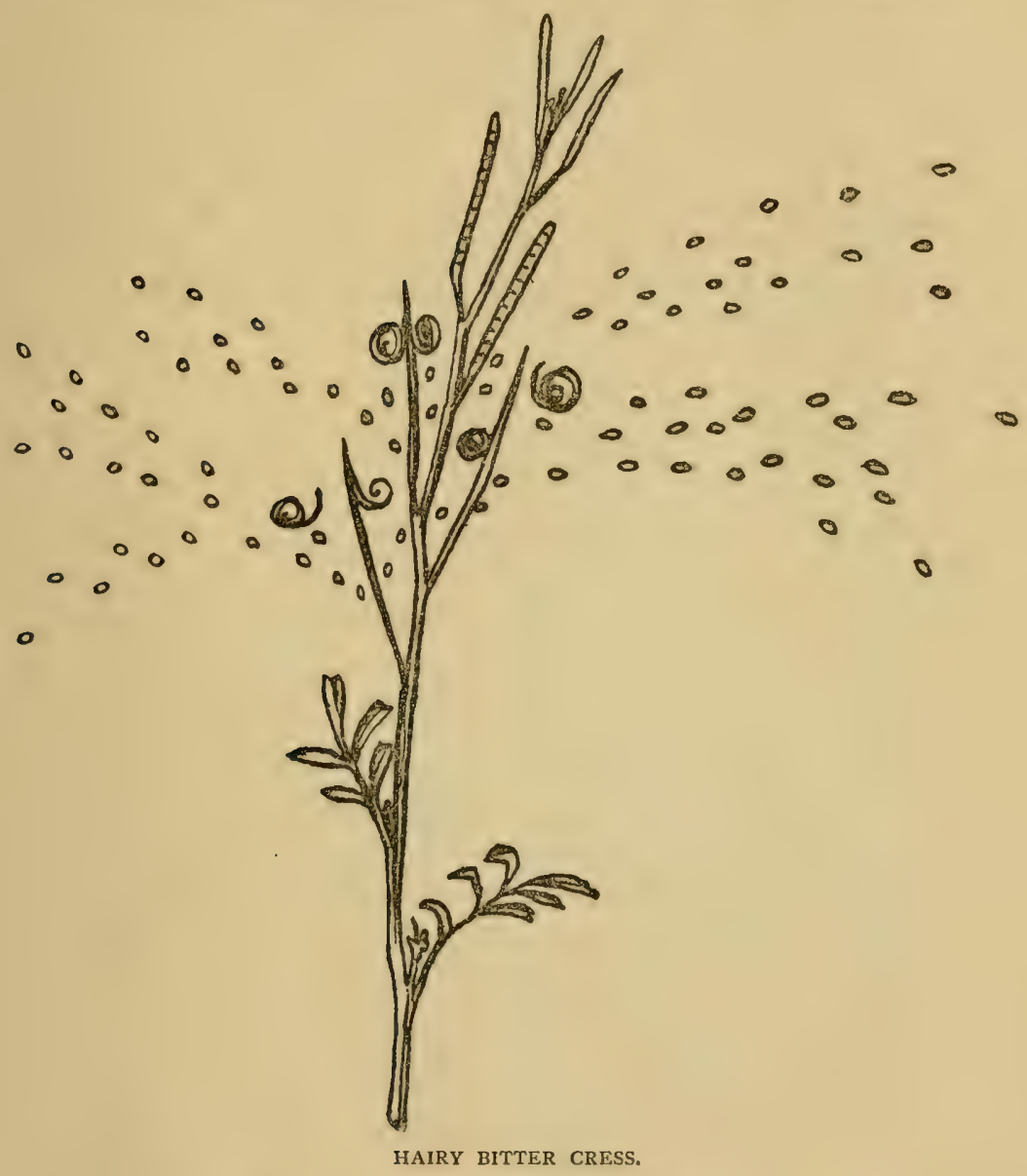

hirsuta. You pull it up and cut off the little root, and, if it is not perfectly clean you wash it, and dry it in a clean cloth, and you eat it for nursery tea. Put 


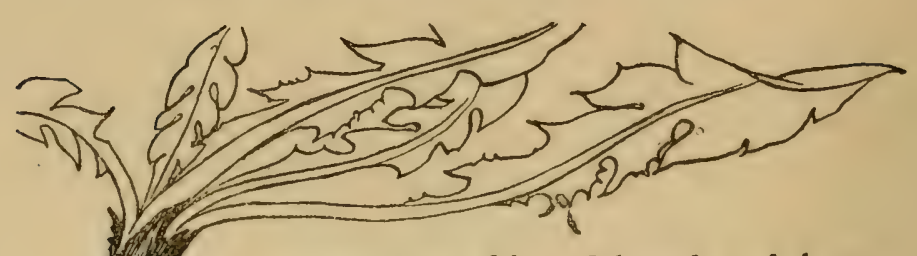

between two bits of bread and butter it is delicious; just as good as Watercress. And if it transmits to you its fine quality of perseverance, why, you will be none the worse.

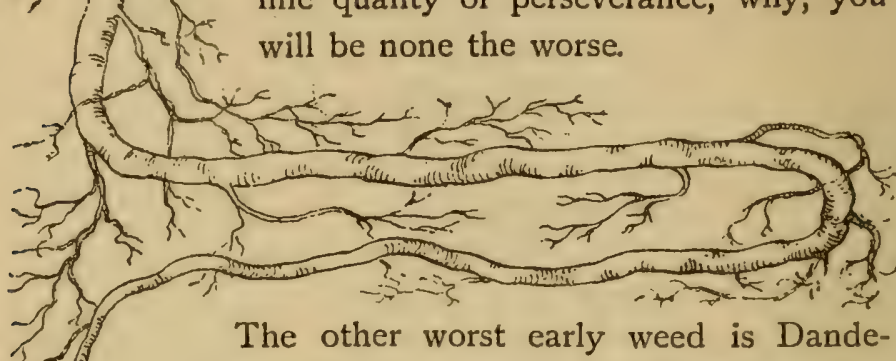

The other worst early weed is Dandelion. It is a perennial. There can be no doubt about that when you look at its root. Many are bigger and deeper-rooted than the one I have drawn. And it is no use just to pull off the top. When you are weeding you should always use a little blunt knife; there is a good sort of short strong knife with a smooth horn handle that costs sevenpence. It should be one of your regular tools. If you cannot get the Dandelion root right up you should scratch away some of the top soil and cut the root as far down as you can reach with the blade of the knife. If you cut it only an inch underDANDELION. ground it will make fresh crowns and be 


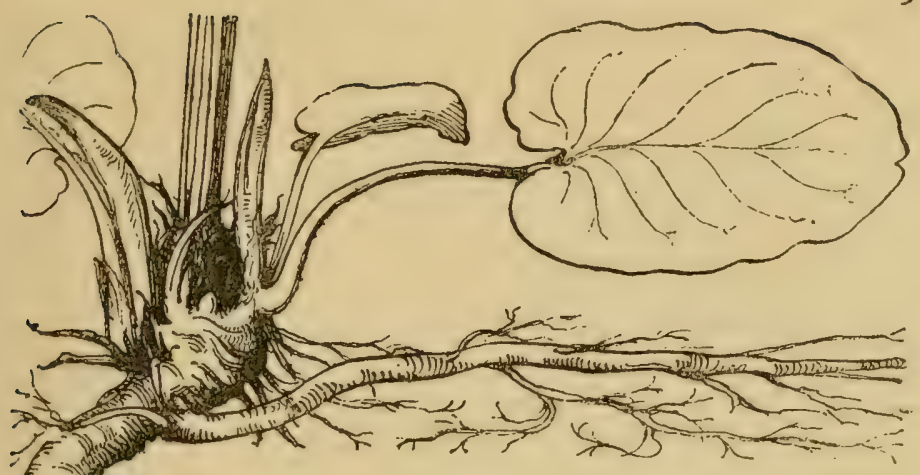

worse than ever. Notice that word "crown." Applied to a plant it means the thick growing part next above the root, the preparation for the whole of the plant that will come up above ground. It is not every perennial plant that will make new crowns when you cut the top off an inch below ground. But Dandelions and

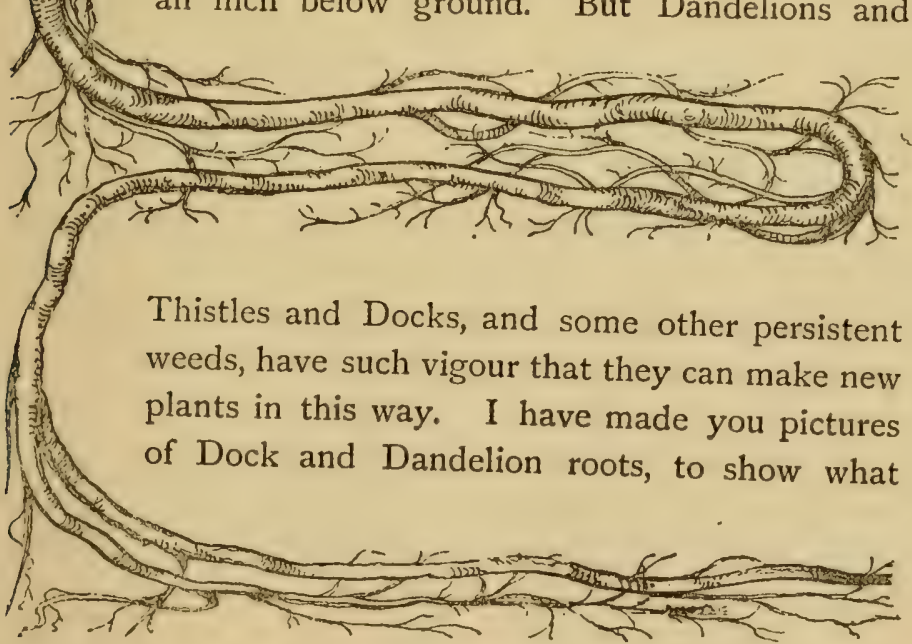

Dock. 
mighty things they are even when the leaves are only beginning.

You will see all about crowns when you come to dividing perennial plants in autumn. Among the died-down or cut-off stems of the past year you will see the little whitish points of the growth for the year to come. These are the crowns, that will grow into stem, leaves, and flowers; one or more crowns with some roots is considered a safe division or suitable new piece to plant. Of course, if a Dandelion plant should grow up among other things and escape notice you will know it at once by its flower. Then you must make sure to have it up and not let it make its pretty "puff" of seed, or you will be bothered next year with a very troublesome crop of weeds. But you must be always on the look-out for them, for even if you are as careful as possible in your own garden you cannot help the seeds sailing in from fields and hedges and road-sides; and they will sail from a long distance.

Thistle seeds sail in just in the same way. If you ever find a little seedling Thistle in your garden you must dig down and get the root out whole. If you don't get it out young you wili never get it out at all. 


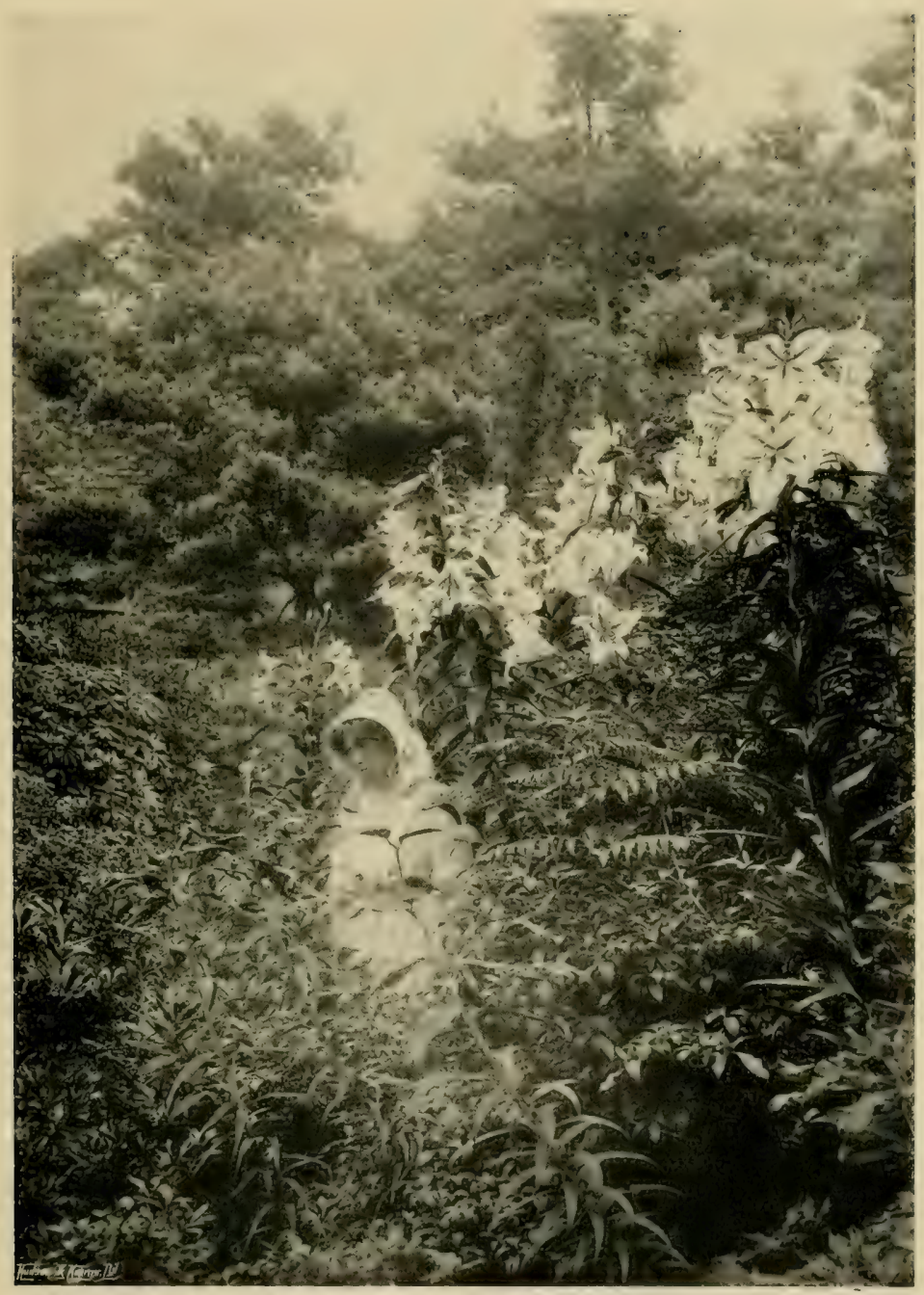

AMONG THE BIG LILIES. 


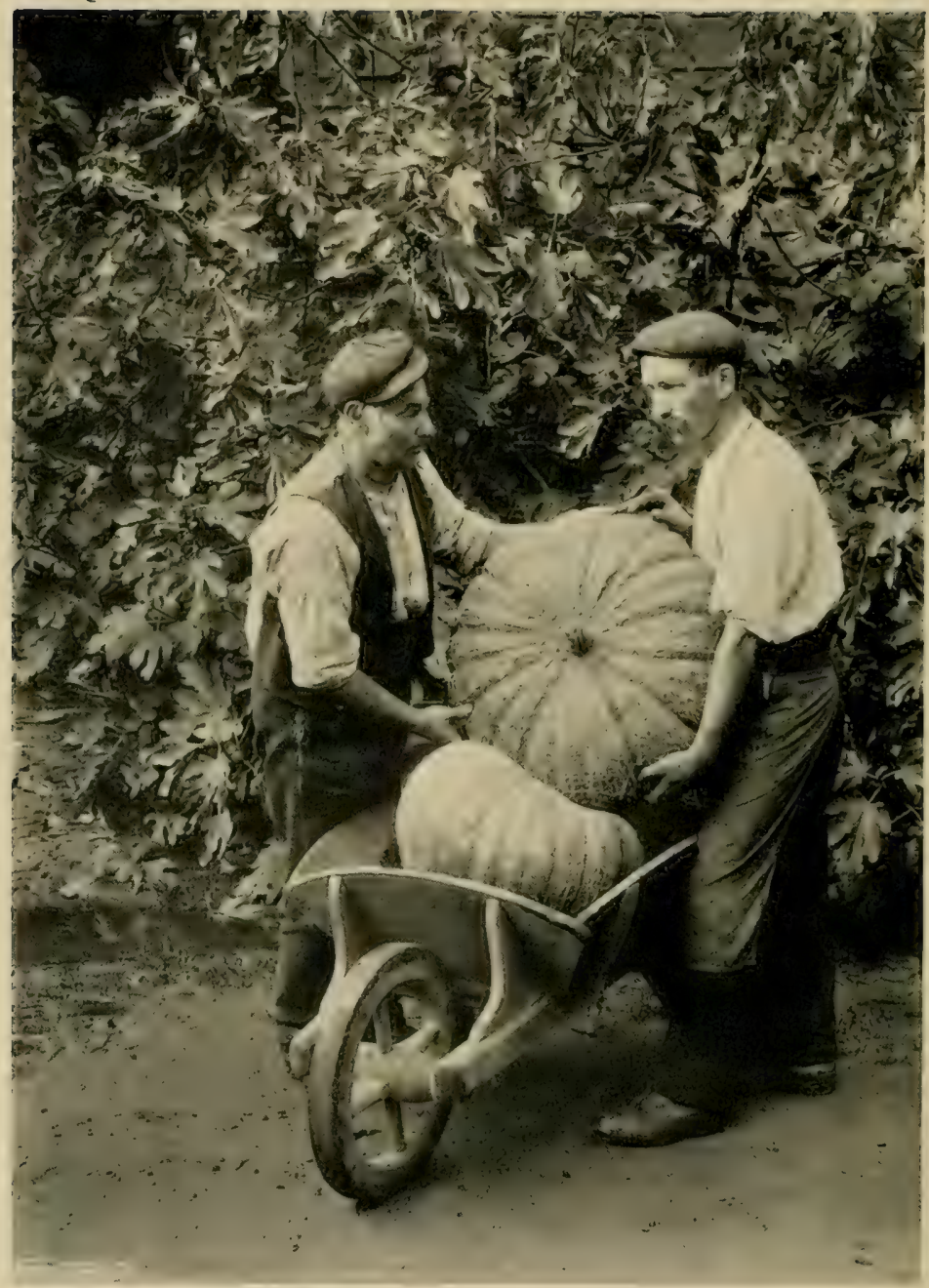

THE GREAT PUMPIIN OR GOURD. 


\section{CHAPTER IV}

SEEDS

WHEN March comes we have to think about seedsowing. From the middle to the end of the month is the time for garden annuals, though Sweet-Peas are best sown earlier, towards the end of February.

One cannot help observing what different-looking things seeds are; how endlessly they vary in shape and size. There are some so tiny that one can scarcely see them, and some, like a kitchen-garden Broad Bean, as wide as a shilling; to say nothing of great monsters like Cocoa-nuts. For all nuts are only single seeds. Think of all the different ways seeds grow : in loose papery shucks

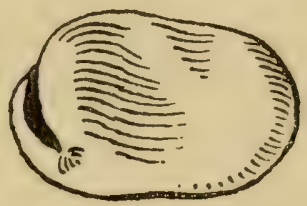

BROAD BEAN. like Indian Corn, in neat pods like Peas, in beautifully-

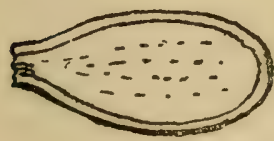

GOURD SEED. shaped urns like Poppies, and in hundreds of other ways. Then think of all the different seeds of fruits. Sometimes it is a big longish seed like a Plum or Peach-stone inside a delicious pulp, or a smaller one like a Cherry-stone 
or an Orange-pip. Generally in a fruit the seed is inside, but sometimes it sticks on outside. The little yellow flecks on the outsides of Strawberries are the seeds.

Then in handling seeds one notices differences of touch and texture. There are fluffy ones like those of Anemones, and rough-coated ones like little bits of coal cinder, such as Love-in-a-Mist, and others so slippery that you can scarcely hold them, such as the shiny black seeds of Columbines.

Then just think, when the seed is ripe and ready to be sent away from the parent plant to find its place in the earth and make new plants, how the various kinds are fitted with different ways of finding a new home. Many, it is true, fall to the earth and spring up near the old plant, but others have all sorts of curious mechanical contrivances. There is a common roadside plant that grows all round the Mediterranean called the Squirting Cucumber. When the seeds are ripe and the pod falls off its stalk, a little hole is left where the stalk fitted. The inside of the fruit is all watery stuff and seeds; at the time of ripeness the wet stuff seems to be explosive, like ginger-beer that is well "up." It flies out of the hole, carrying the seeds with it and scatters them away to a distance of several yards. It any of you go to the Riviera in the winter, you would be sure to find this plant. The least touch sends the ripe seeds flying, even the vibration of the earth when any one walks near will make them go off; only take care, for you might get hit in the face. It is a greyish plant, growing close to the ground, with biggish leaves something like our roadside Burdock. 
There are other seeds that are shot out with a catapult action, and there is a thing that grows in the West Indies whose seeds, if you bring them indoors, go off in the night like pistol-shots and alarm the whole house. All these are what one may call violent seeds. But most of those that we have to do with are passive and gentle, and many have delightfully graceful ways of moving about with pretty sails or wings. Look at this seed of Clematis montana, with a tail just like a squirrel's! And think how in the autumn one sees Thistle seed sailing away high up in the air, and think of the Dandelion puffs that you may watch sailing

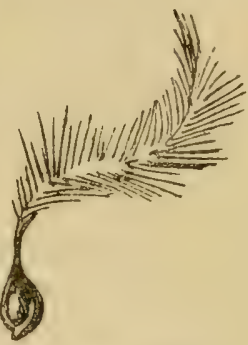

SEED OF CLENATIS MONTANA. shorter distances close at hand. The Hawkweed seed in the picture is one of this kind.

SEED OF HAWK-

The seeds of many trees travel quite WEED.

a good way. When the first hot sunny days come in March, if you are in a wood of Scotch Firs, or, better still, somewhere at its sunny edge, you will hear the last year's cones opening with a sharp snick. Then look about and see if you don't see the seeds fluttering down, looking like little live things. Just catch one or two seeds as they come down and look at them, for if you do not catch them at once, and they lie on the ground for a few hours, the seed will have dropped out of its lodging in the butt of the wing, where it is only slightly held by one edge, 
something in the same way as precious stones are held in the setting of a jewel, only with the purpose that they should fall out easily instead of being firmly held. You will see how like the wing is to a big fly's or

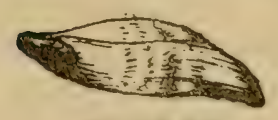

SCOTCH FIR.

beetle's wing, with one strong front edge and little veins. These seedwings shine as they lie on the ground, for the texture is something between the thinnest paper and the finest gauze. The seed is nearly black, but the wing is pale buff with brown ribs and veins. As it lies within the woody partitions of the cone, the wing is slightly curved. This is what makes it flutter and helps the lightest air or wind to carry it a little way away.

And don't forget to keep your noses snuffing about, for these early hot days bring out the sweet scent of the Pines, and it is a smell you will love to the end of your days.

The seeds of the Sycamore-tree flutter away on strong wings that are almost exactly like the wings of a large beetle. Acorns are solid heavy things, that just flop down under the tree they grow on, but the little wood people-squirrels, mice, and birds-carry them about. Some they let fall on the way, but the greater number they hide in all sorts of places. Many of these places they never find again, and acorns grow where they are left, often a good distance from the tree.

Before sowing you should see that your garden is quite clear of weeds. You will just be able to see the crowns of the perennial plants pushing up through the 
ground. You must go all round these carefully with the hoe, hoeing quite shallow so as not to disturb any of their roots that are near the surface, and then go over the ground roughly with the rake, not for the sake of tidying and gathering up any bits of rubbish only, but also to break up any cloddiness of surface and let in the air, and to let the seeds fall into the tiny holes made by the teeth of the rake.

Always remember that you can never sow seed thin enough. The very small seeds you can prepare like this. Take a tiny pinch of seed, not half a quarter of what is in the packet, and get about a tablespoonful of fine dry earth or sand. Mix the seed with the earth and sow a very little of the mixture. You should always do this with Poppy seed, and until you become expert it is much better to do it with all seeds except fair-sized ones, that you can be sure to sow thinly. Big seed like Lupine or Sunflower can be sown quite singly, putting in one seed just where you want the plant to be. But if there are many slugs about, it is safer to sow three seeds, a couple of inches apart, instead of one; then if a hungry slug comes along he may perhaps eat one, or even two, with a good chance of the third being left. If no slug comes and all three are growing well, and have got beyond the size when the slugs like them best, which is when they are still in seed-leaf, then if there comes a nice day when the ground is damp after a shower, you can take up the two extra plants very carefully with a trowel, so as not to disturb the third, and plant them elsewhere; or, if you have no room for them, you can pull up the two worst 
plants, leaving only the best. The smaller the seed the shallower it should be in the ground. All ordinary seeds may just be scattered over the ground that has been freshly scratched over with the rake. Then you pass the rake over again, and that is quite enough to cover the seed. The hoeing will have killed any weed seeds that would have been beginning to grow, so that when you see little green things coming up, you may be pretty sure that they are your flowers and not weeds. You will very soon get to know the difference, even when the tiny plants are in their first pair of seed-leaves, but meanwhile, when you see in your sown patches seedlings coming up that look all alike, you may take it that they are what you have sown. As soon as they are big enough to handle you must thin them out. How much to thin, that is to say, how near to each other the little plants may stand, is a thing that you must partly learn by experience; but of course small plants, such as Virginian Stock, can stand much nearer than big things like Lupines. To begin with, you can teach yourself this way. Look in your seed-merchant's list. The good ones give the height to which the plant grows. Most plants spread to nearly the same measure as their height, some a great deal more; but as a general rule you may let the seedlings stand at a distance apart equal to half their height. Therefore if you see in the seed list that the plant grows a foot high, let the seedlings stand six inches apart. But if they have been sown too thick, and in some places come up quite close together like a turf, you must pull these up altogether; they will never make good plants, 
but leave enough of those that stand so singly, that any thinning you have to do round them does not disturb the roots of those that are left.

When I was young one used often to see what I think is a very silly way of sowing annuals. A little ring, about as big as a dinner plate, was scratched in the ground, the seed was sown in this much too thick, and the seed-paper, with the name of the plant on it, was pushed into a cleft in the top of a short stick which was stuck in the middle of the ring. Bits of paper always look bad about a garden, and it is a lazy way of marking the plant. Gardens look much better if you can do without any labels, but if you must have them the nicest are bits of hazel stick cut about a foot long and pointed, with the top end shaved flat for a length of about two inches to write on. It must not be shaved too deep, because in the middle of the stick there is a little pithy hollow. Then you have a little pot of white-lead paint; you take a very little of this on the end of some other bit of stick and smear it over the shaved part. Then with a bit of rag or paper you smooth it over and rub most of it off. Then you write the name of the plant with a soft pencil in the thin coating of wet paint. I always have the paint in the bottom of a small-sized jam-pot, and have a bit of rag big enough to crumple into the top of the pot without touching the paint, so that it keeps most of the air away that would dry it up and make it unfit to use.

I can only think of one sort of seed that should be sown fairly thick, that is Mustard and Cress. This small salad is generally sown in frames, and the seed 
merely scattered on the surface; but you cannot do that out-of-doors; the birds would have it directly, so you must just cover it up.

Of course I suppose that you not only attend to your own gardens but also watch all that is being done in the big home garden. Some day you will grow up, and perhaps have big gardens of your own, and if you have learnt to know a lot about it when you were little, it will make you fit to take charge and to say how things are to be done, and to make the garden a glory and delight to yourselves and everybody else. So at seedsowing time you should see what the gardener is doing inside-that is to say, in frames and greenhouses-as well as out. You will find he is sowing lots of seed in pans and little shallow boxes. Some of these are half-hardy annuals; grand things like African Marigolds and Zinnias, and Stocks and Asters. They want a warmer climate than ours for growing straight out-ofdoors, so we sow them "in heat," as gardeners say, or at any rate with the protection of a frame. This is the best chance to watch the way the little seedlings come out of the ground and to get to know them in the seedleaf state. For most plants begin their growth with a pair of seed-leaves that are of a simple shape, quite unlike that of the leaves that are to follow. When the next pair of leaves comes we speak of the seedling as being "just out of seed-leaf," and about a fortnight later we speak of the seedlings as being "big enough to handle"; many of them are then "pricked off " separately. "Pricking off" means separating the little plants and planting them in rows in other boxes, where they re- 


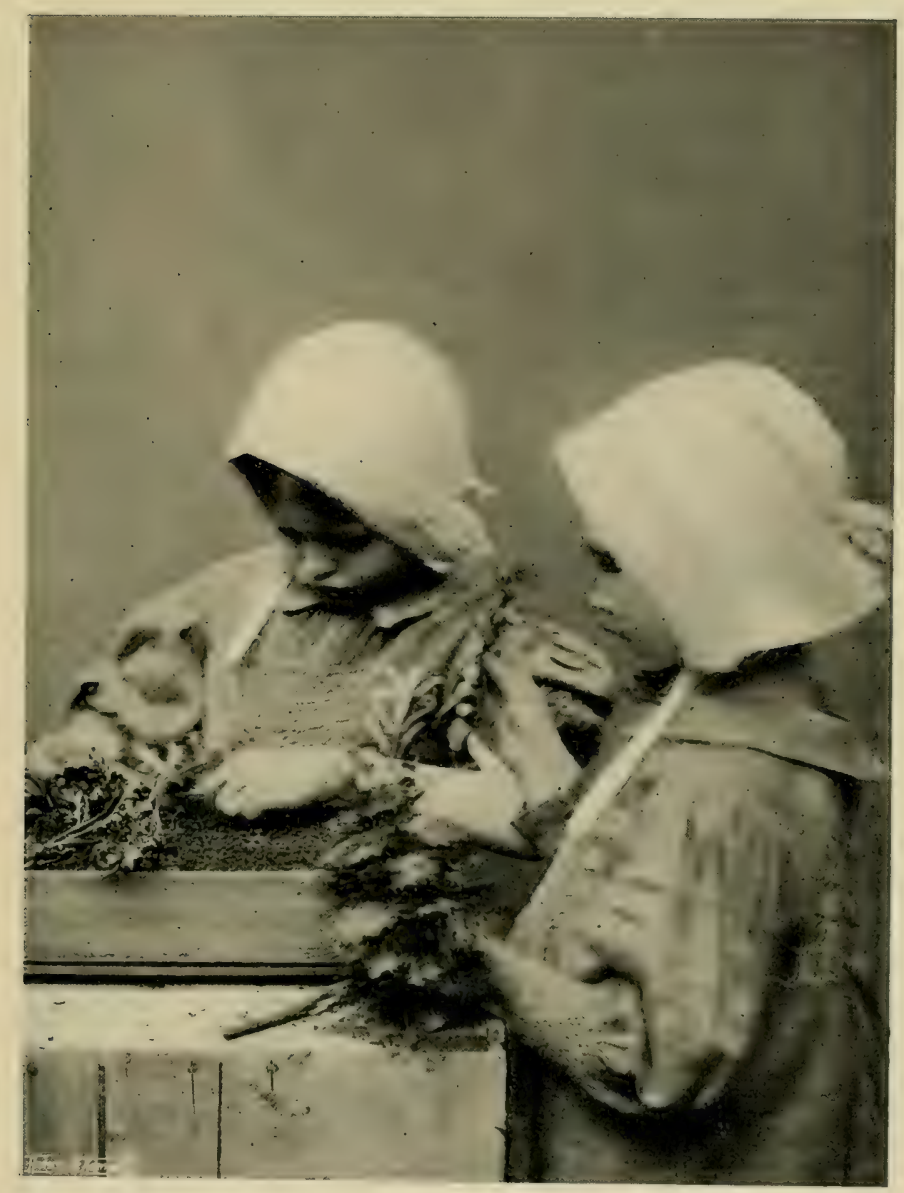

PRICKING OFF SEEDLINGS. 


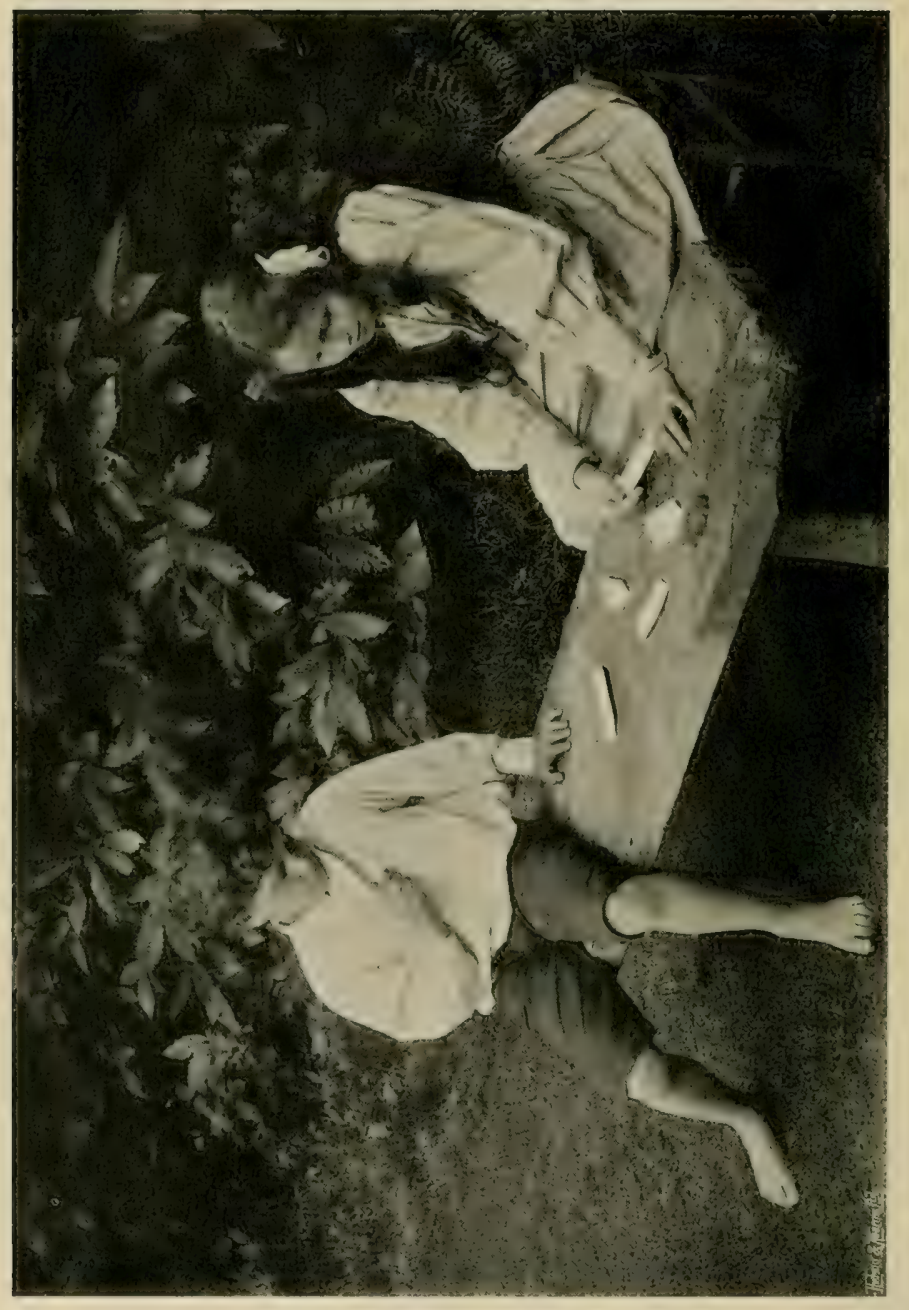

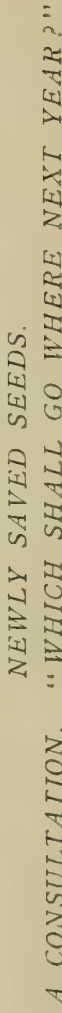


main till they are of the right size, and the right time has come to put them in their places for the summer. The gardener will show you how to do it, and the blunt wooden tool to do it with, which you can make yourself.

To go back to the seedlings that have just come up. You see them quite conveniently if the boxes are standing on the greenhouse staging. Here and there among them you will see what an odd way some have of carrying up the coating or husk on the tips of the
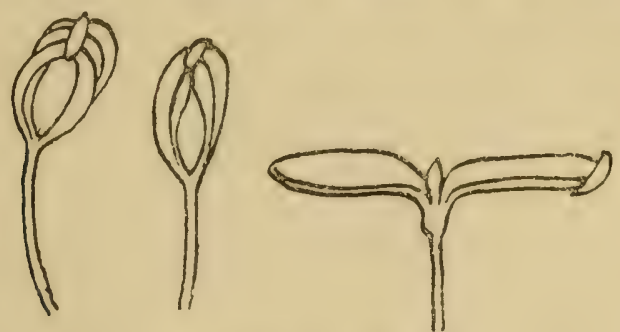

CHINA ASTERS IN SEED-LEAF.

seed-leaves. I have drawn this to show you from a pan of China Asters. The pair of seed-leaves want to open flat, but sometimes they are held clipped together by the husk. The seedling will be very thankful if you will gently release them by lifting off the husk. The best way to do it is with a little flat feather, pushing the feather between the two leaves and working it upwards, very gently, or the seedling may be pulled out of the ground. The husk often sticks on the end of one seed-leaf, though it is more often thrown off altogether.

The seedlings with the little ace-of-spades shaped 
leaves are Incarvillea Delavayi, a handsome perennial plant. When the husks hold on to this they do it in a very clever way and stick rather tight. The coating of the seed has a broad back on one side and a pointed tongue on the other, so that it rides astride of the leaftip with a rather firm hold.

In your own gardens it is best, when the flowers are running to seed, to cut them off directly the flower is over. You see you want all the flowers you can get

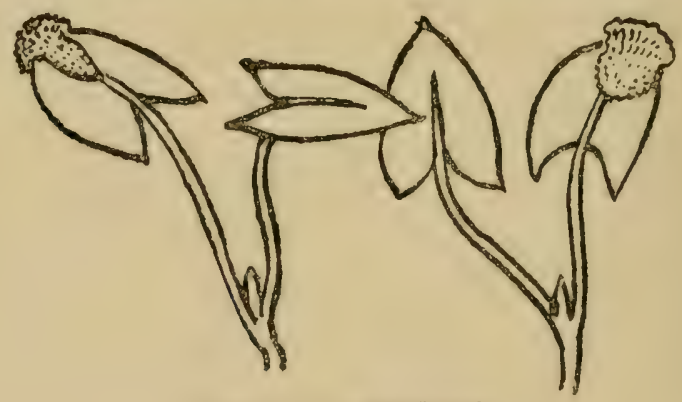

INCARVILLEA SEEDLINGS.

to keep your garden bright, but the plant wants to make its seed as soon as possible. When seed-pods are forming the plant tries to give all its strength to the seed-pods, but it is very patient, and if you go on cutting off the seed-pods it will make more flowers, in the hope that next time you will not see or will forget. But by watching carefully and cutting off every pod, it is quite wonderful how you can make a plant go on flowering.

Most likely you will find plants going to seed somewhere in the home garden. Towards the end of the summer you should look out for these to save the seed, 
and then you will see the curious variety of the seedpods, and the ways the pods have of protecting the seeds till they are ripe, and then sowing them themselves; and you will see what odd things some of the pods are. Look at the picture of the pretty Love-in-aMist. The plant has two English names, Love-in-aMist and Devil-in-a-Bush. I always think that one name belongs to the flower and the other to the seed-pod.

Some seed-pods, when the seed is ripe, have little holes near the top. I have drawn you a Bell-flower seed to show this ; Snapdragons have two holes, they are the eyes of the little old woman that I will tell you about; and you must know the look of the row of holes under the crowning top of a Poppy pod. And get somebody to show you how to make a seed-paper, to keep seeds in. Most seedsmen now use the little SEED-POD seed pockets and gum them up, but a few FLower. still use the good old-fashioned folded seed-papers. If you can get hold of one of these you have only to unfold it to see how it is made.

A curious seed is that of Honesty. I daresay you have seen the silvery insides of Honesty pods used as winter ornaments. If not, and you have Honesty plants going to seed, I advise you to watch them in August. I am not very fond of winter bouquets of anything that looks dry and rather artificial, but I must say I do like the silvery Honesty. It is only good if the plant dries off naturally in fine dry weather, 
because if, while it is drying, it is wetted by any continuous rain, the brown seeds stain the tender tissue that you want to keep. The seed-pod is quite flat. It has two outer coats like whity-brown paper, and

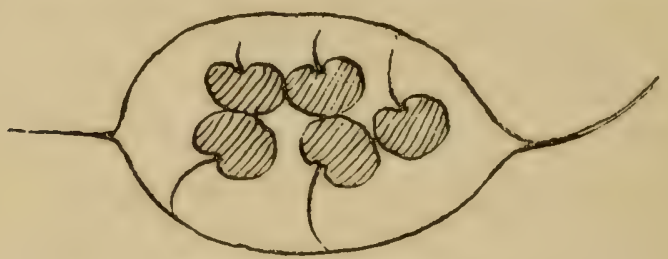

SEED-POD OF HONESTY.

generally three to five seeds, some on one side and some on the other of another middle papery partition. It is this partition that is kept. It is of delicate texture, half transparent, and has the silvery-satin lustre that makes it such a pretty thing set up in a room in some handsome blue-and-white Chinese jar or

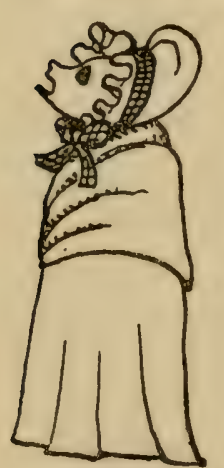

SNAPDRAGON POD DRESSED AS AN OLD WOMAN.

Japanese bronze. I have drawn it as it looks held up to the light. I know no better practice in careful handling for young fingers than the preparing of the pods, doing it so as to get off the two outside paper covers and the seeds without injuring the middle.

It is amusing to dress up a Snapdragon seed-pod, when it is brown and dry, as an old woman. If you look at it you will see how curiously like a face it is, with large eyes and open mouth. You must break off the projecting spike so that it leaves a little 


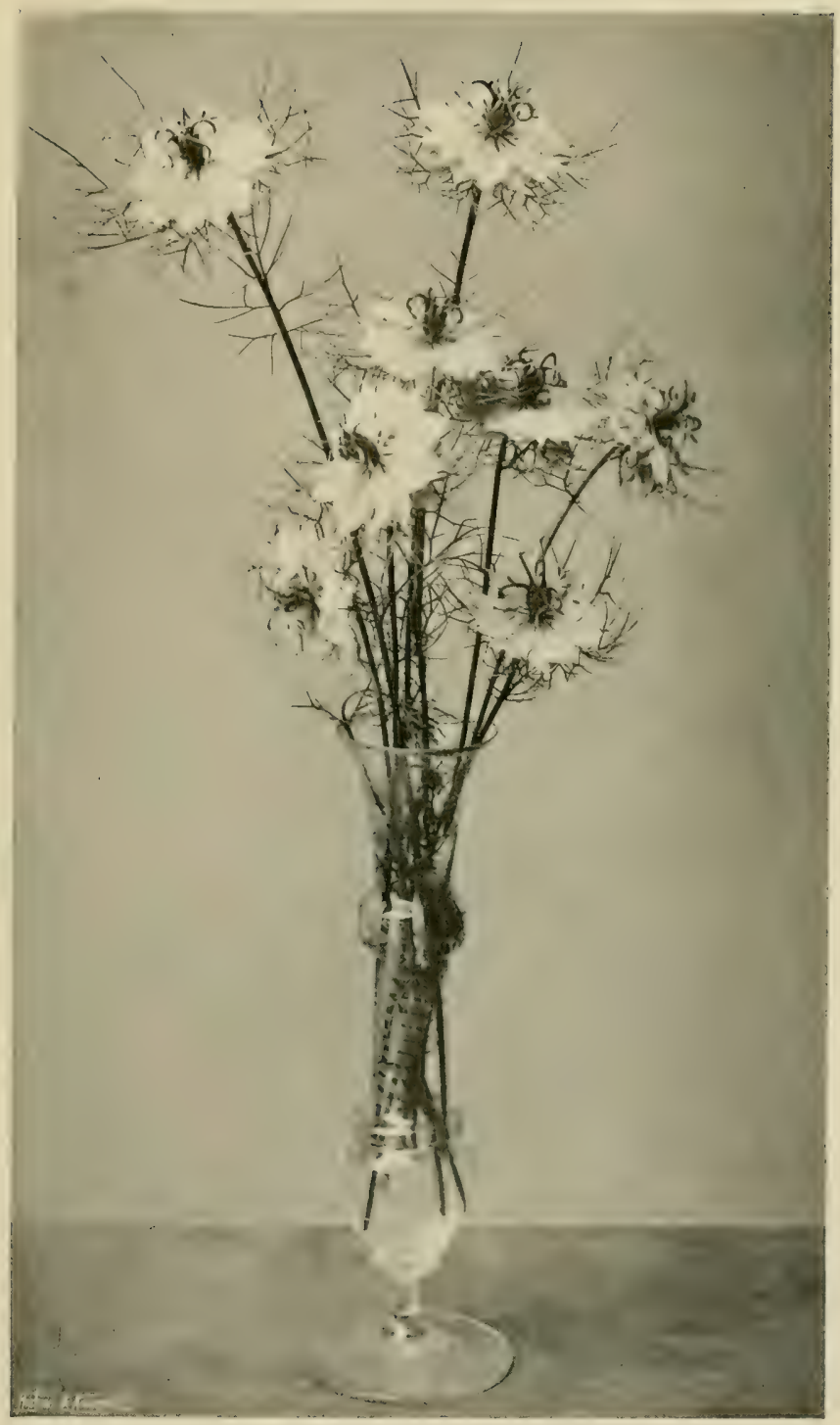

LOVE-IN-A-MIST. 


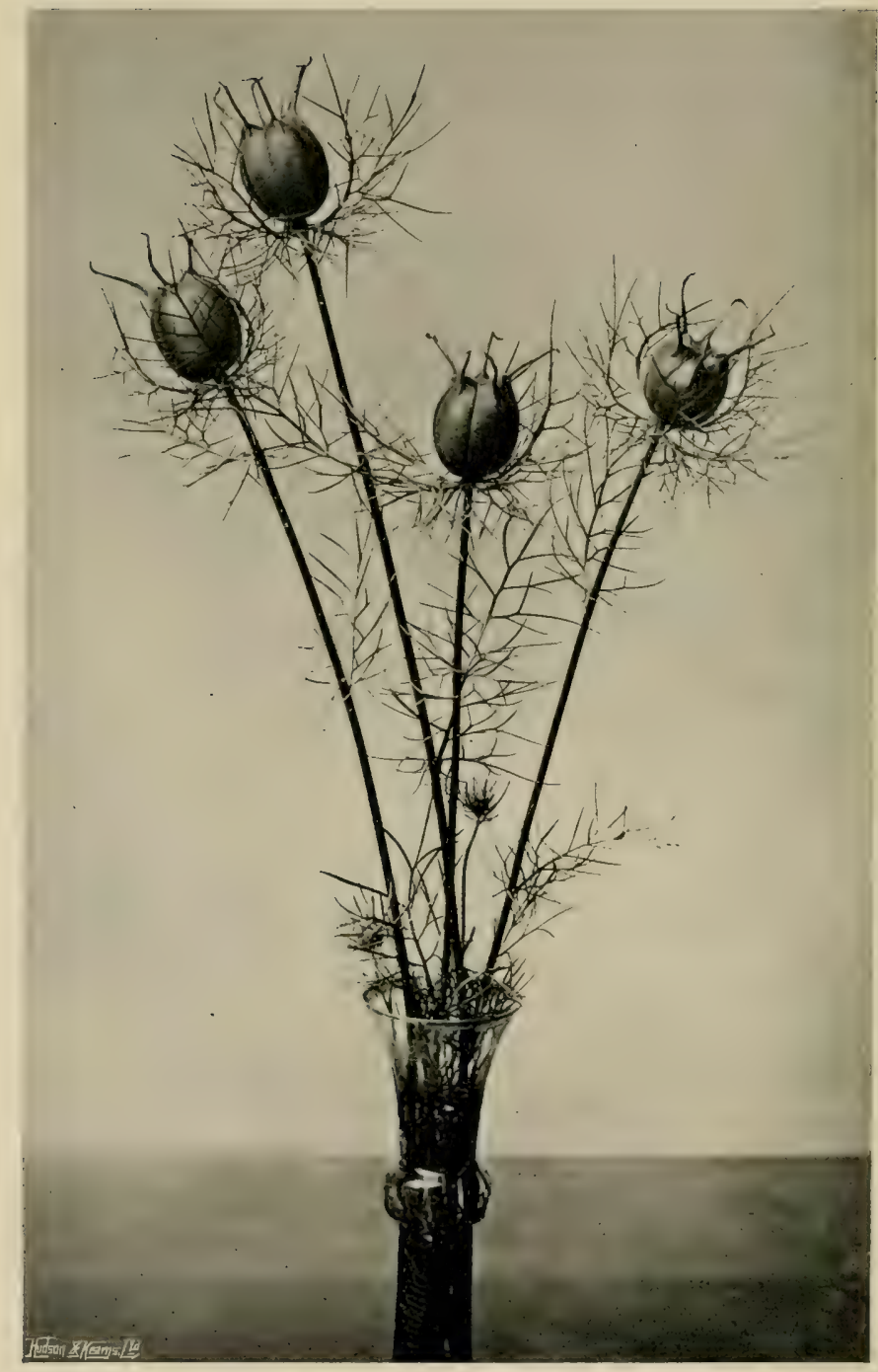

DEVIL-IN-A-BUSH. 


\section{SEEDS}

turned-up snub nose. Then you get a cork and whittle away a bit at the top, and you send a pin through the pod and down into the cork. She must have a large mob cap with a frill round the face, a shawl, and a petticoat. Any one who can dress dolls can make this. If you shake her she weeps little black tears. 


\section{CHAPTER V}

COWSLIP TIME

If you live in a Cowslip country you will naturally want to make Cowslip balls. You prepare the flowers by cutting off the stalks just under the heads, and stretch a bit of very fine string by tying it to the backs of two chairs ; or you may tie the string to the back of one chair and hold the other end in your left hand. Then you take the prepared flowers one by one and make them ride astride the string, heads downwards. When there are as many on the string as you think will be enough to make the ball, you press them as close up together as they will go, bring up the two ends of the string and tie them. I cannot tell you how many heads it will take, because that depends on the size of the cowslips and the number of flowers on the heads - you must try for yourselves and find out. The ball must be tight and round, and made of flowers that are about the same length. If they are of different lengths the ball will have an uneven surface. It should be even and plump and round. The little Birds'-foot Trefoil that grows by road-sides in the summer makes very pretty little balls, and you can make them of any 

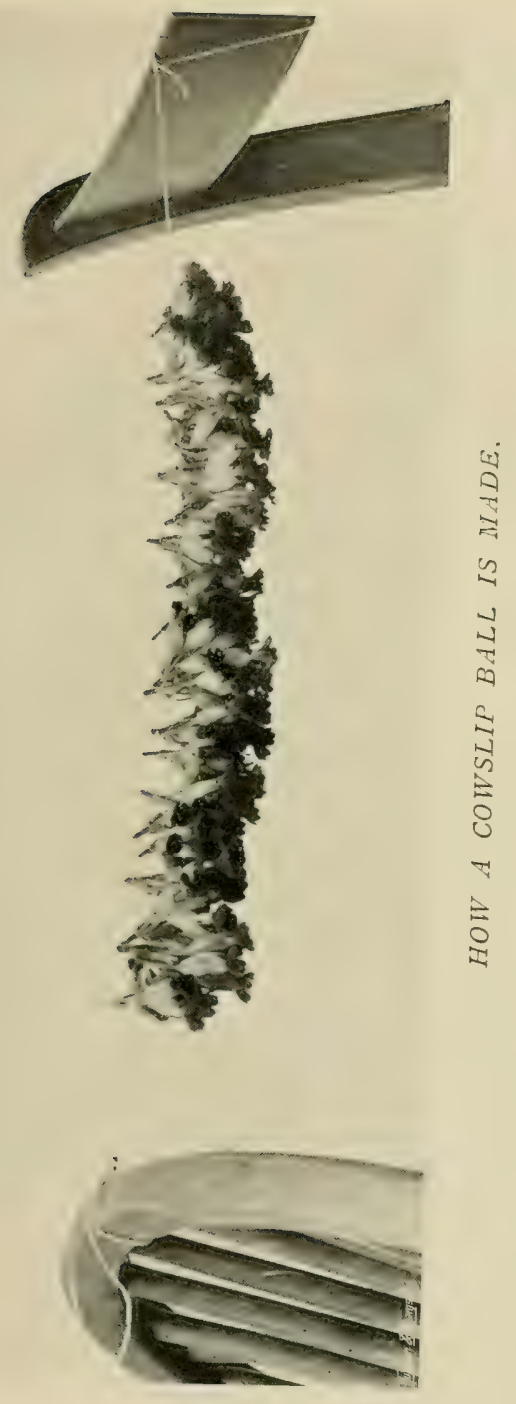


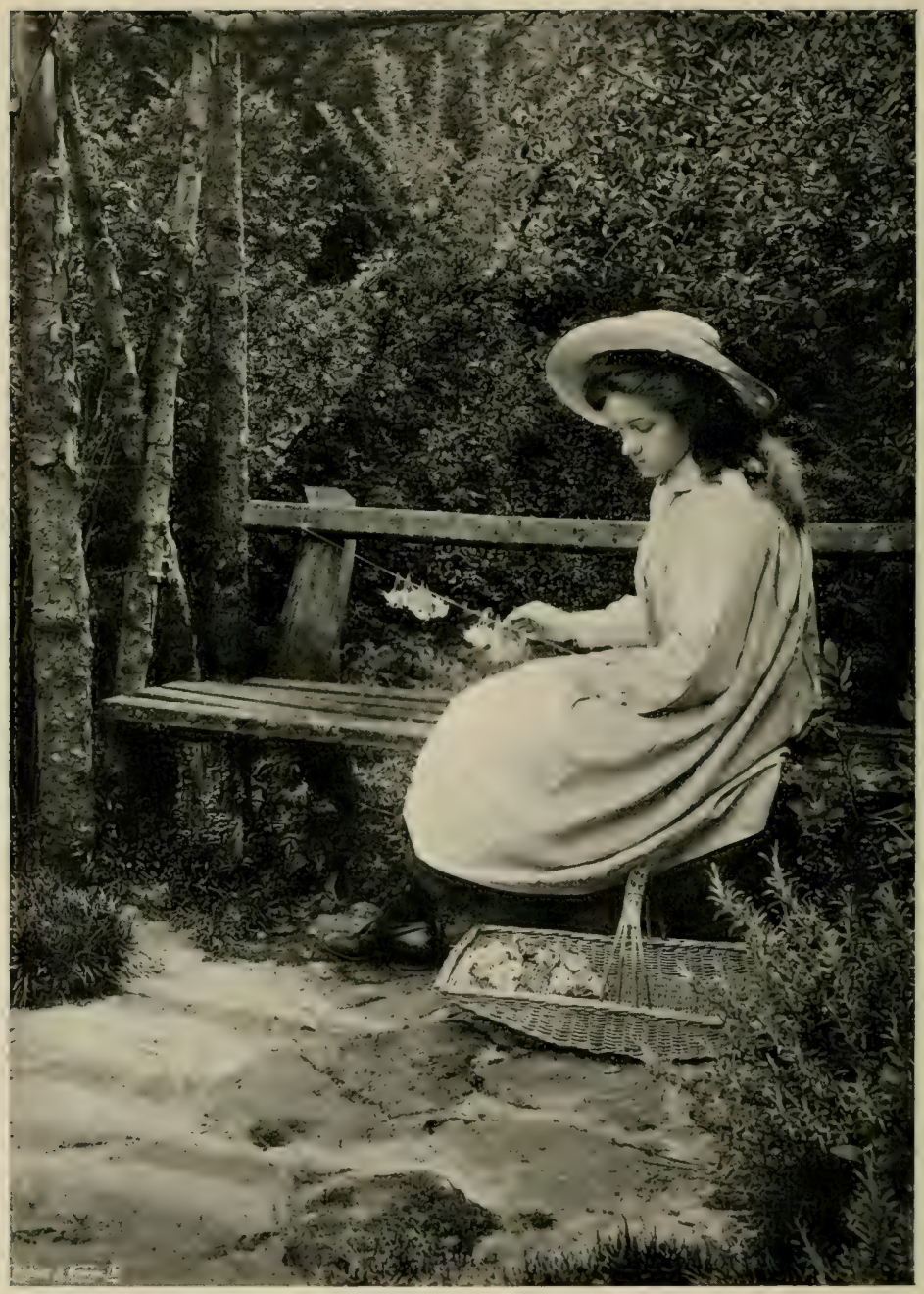

MAKING A PRIMROSE BALL. 


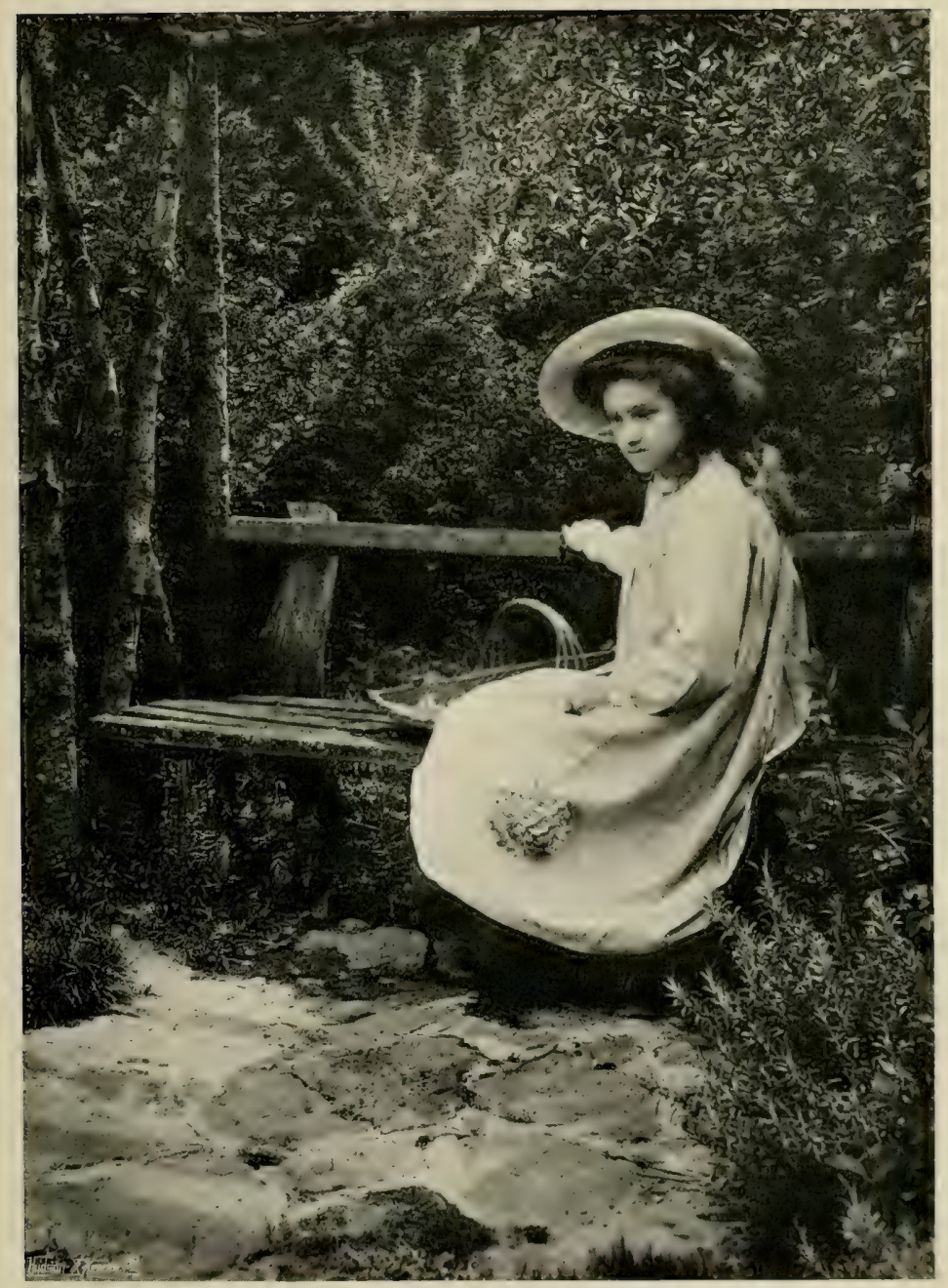

A PRIMROSE BALL. 


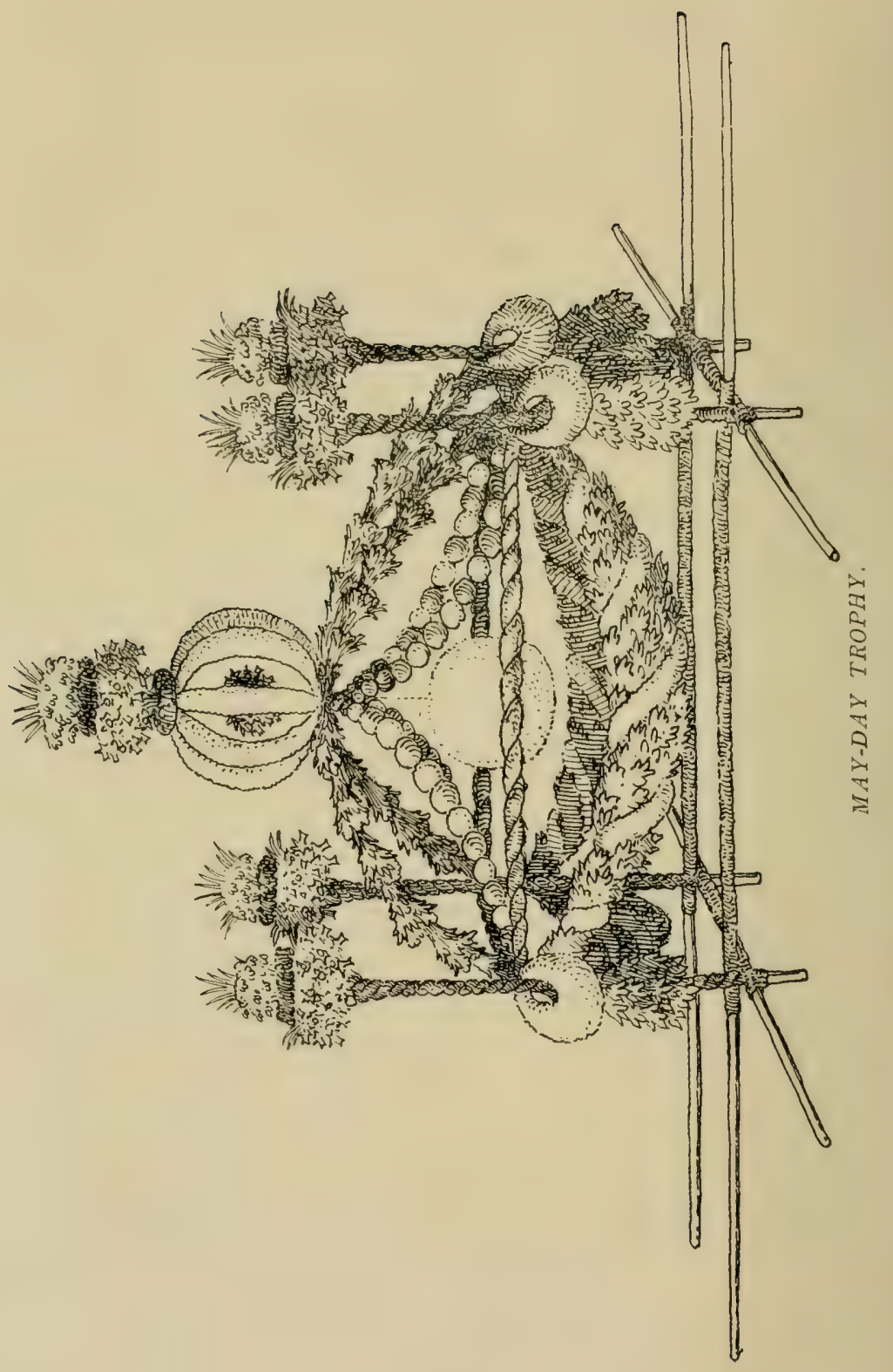


flowers that grow in the same way. Primrose balls can be made too, not only of Polyanthus Primroses, that grow something like Cowslips in a head of a number of flowers at the end of a stalk, but also of common Primroses, by tying six or eight flowers together with a bit of thread at the stalk end, keeping the stalks of all the flowers the same length, and then using the bunch of six or eight as you would a Cowslip. The longer the stalks are the larger the ball will be.

Once I made an immense Cowslip ball two feet in diameter. It was not at the old home, but at an intermediate home in the valley of the Thames, on a chalky soil where Cowslips abounded, and where, on a big island in the river, there grew a quantity of the summer Snowflake, like gigantic Snowdrops. The village children used to come round on May-day with bunches of flowers, but they did it in a scrappy sort of way, and we wanted to help them to do it better. So besides the bunches of flowers on peeled willow sticks, and the hoops of flowers carried by two children by passing a white willow stick through the hoop, that they made for themselves, I undertook to make a grand May-day trophy. Here is a picture of it. The framework was made of strong, light willow poles tied tightly together with iron wire. All the straight parts in the picture are these poles. Then, to support the round sort of cage at the top, two strong willow rods were bent up to a nice bow-shape, and fastened where they crossed, and also to the frame at their four ends. Then the cage itself was made of four rods bent round into 


\section{CHILDREN AND GARDENS}

hoops, passed through each other, and firmly wired at the top and bottom, so as to make a hollow ball with eight ribs standing at equal distances apart. The next thing was to cover the straight parts of the framework with moss, all but the carrying ends, the upper horizontal rails, and the bowed supports. The moss was put plain on the carrying poles, but in a ropy pattern that was more ornamental on the four uprights. After that the heavy swags for the four sides were made of Laurel twigs, thickest in the middle. Something was put inside to puff it out-I forget what, but some sort of bushy branches. And the four big tassels that hung under the Cowslip collars at the corners were made too, and the evergreen parts of the bunch-after-bunch patterns on the bowed ribs. These had flowers added afterwards. All this was got ready quite three days before the Ist of May, and in the next two days the flowers were collected and bunched. The flowers were Cowslips, Primroses, Daffodils, Snowflake, Bluebells, and Ribes (the red flowering Currant). The four big upright bouquets were made of white Snowflake at the top, with some stiffish pale green leaves. I think these were the young leaves of some of the river flags. Next below the Snowflake came red Ribes and then Daffodils. The bouquet crowning the cage was made to match, with a red collar of Ribes just on top of the cage. The ribs of the cage were of Primroses and Cowslips alternately, showing as pale and deep yellow with a very pretty effect. A bunch of Daffodils hung inside. Then there were four ropes of balls, a Cowslip and a Primrose ball coming alternately all along the rope. These, as you 
see, all started from one point under the cage, and had their ends fastened to the four inside angles of the frame. The horizontal rails of the frame were covered with Bluebells tied on so as to look ropy. Then there were ropes of Primroses-quantities of small bunches tied on to a thick string-wound round the heavy swags of evergreen.

But the glory of the whole trophy was the great Cowslip ball that hung in the middle. It was made like this. First, Cowslips with long stalks were tied in bunches, leaving a string hanging out at the ends of the stalks. The bunches were tied all the way down the stalks. Then six bunches were tied together by the strings coming out at the ends. When enough of these bunches of bunches were made ready-they were left in water all the day before-each bunch of bunches was treated as you would treat a single Cowslip head, and slung head downwards over a very strong string, the ends of which were brought together and tied, as in an ordinary Cowslip ball.

There was a lot of work in it, as you may imagine, but I had several kind helpers in the dear girls at the vicarage, for no one pair of hands could possibly have either collected or bunched the flowers, or have got them into place on the May-day morning. The whole thing was most amusing, but then it is always the greatest fun to invent and contrive and get over difficulties. The trophy was carried by twelve little schoolgirls, two to each end of the long poles, and one at each end of the shorter ones that went across. It had a great success, and brought the children quantities 
of pennies in its progress round the village and its visits to neighbouring houses.

Cowslips always make me think of Morells, one of the best things to eat of the fungus tribe. Most of these come in the autumn, but Morells grow in Cowslip time-often among them-in parks or old pastures, generally near groups of Elm-trees. They look like small sponges standing up on short hollow stalks.

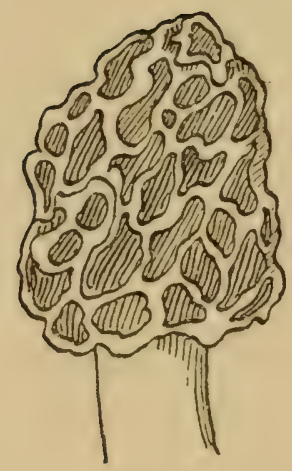

MORELL. 


\section{SMELLS AND SHAPES}

WHEN I was a child I was very much alone, and nearly always in my playtime found my own amusements in the garden and shrubbery. There was a large rambling shrub garden with broad turf paths; and though it must even then have been planted for many years - and in those days a well-planted shrubbery was a rare thing -yet it contained many delightful shrubs and trees, such as are the very best to this day. A part of it was in moist, peaty soil, and in this region were Rhododendrons, Azaleas, Kalmias, and Andromedas. One Andromeda I used almost to worship; it was a bush, with the flowers on a level with my head. I did not know its name then, but, to myself, used to call it the Snowdrop-tree.

I got to know every flower in the place most intimately, not only for shape and colour and marking, but also for smell. How well I knew all the different Rose smells! There were not then the hosts of lovely Roses that we have now, but each one of the kinds that were there I could distinguish with my eyes shut, and the remembrance of each individual scent has 
always remained with me. In the shrubbery there was a quantity of the single American Rose called Rosa lucida. It has reddish stems and no prickles. The smell is very faint, but quite distinct; and there were bushes of the double Cinnamon Rose, with a sweeter kind of scent, but also not strong; and Damask Rose and Cabbage Rose, with its variety the Moss Rose, with the delicious strong scent of its sticky mossiness in addition to the Rose's own smell. I may say that my young nose became thoroughly trained to the smell of flowers.

Among all the many delicious flower-smells there was, now and then, a nearly nasty one. There was one flower-smell that I always thought odious; that of the common Barberry-the prickly shrub that makes the pretty long-shaped red berries. The flower had one attraction, because, on examining it, I had discovered the sensitiveness of the stamens. These are the little threads inside the flowers that carry the powdery pollen on tiny cushions called anthers on their ends. In this flower and some others the stamens lie back against the inside of the petals. If they are touched-the slightest tickle with the end of a blade of grass is enough-they fly together to the pistil, which is a little post with a knob on the top that most flowers have in some shape or other right in the middle, the root end of the pistil going right down into the throat of the flower. It is so amusing to see a flower make some quick movement, just like a live thing, that this was a great inducement to go to the Barberry bushes in spite of the smell. After a time, 


\section{SMELLS AND SHAPES}

when I learnt how the wind carries scents, I used to approach it cautiously from the windward side. The smell is not really very bad, but of a faint and sickly kind, but I remember years when to me it was so odious that it inspired me with a sort of fear; and when I forgot that the Barberries were near and walked into the smell without expecting it, I used to run away as hard as I could in a kind of terror.

Since I grew up I have only once met with a smell of a growing thing that gave me the same sort of feeling of intense repulsion. It is a spongy weed looking like green coral, that grows in the mud in shallow water. I used to see it in a backwater of the Thames at a later home, when I was leaning over the side of a boat looking at the curious things in the mud at the bottom. I noticed it first when fishing for mussels with a stick. The mussels lie half imbedded in the mud, with their shells a little bit open. If you feel down gently with some small stick like a twig of willow, and get the end just inside the opening, the mussel shuts up tight and you can pull it up on the stick. The mussel is no use when you have got it, so you pull out the stick gently without hurting the creature inside, and throw him back into the water. One day among the mussels I saw the curious green weed. I thought at once that it looked like a soft green coral with rather thick branches. Of course I wanted to examine it, so I scooped some up on the blade of my oar and got hold of it, and turned it over to see it in all positions, and smelt it. The smell to me was horrible, and yet, curiously enough, it was not 
a really nasty smell; it was certainly aromatic, very much like the smell of myrrh. But though I was then twenty-four I felt again that curious sense of fear that I remembered in childish days about the Barberry. The thing attracted me in an odd sort of way, for I smelt it again and again, always with a more intense dislike. Then I threw it away in disgust, but found that though I had got rid of the thing itself, the horrible smell haunted me; for days and days I could not get rid of it; I always seemed to be smelling it. The curious part of it, when I came to think of it, was that I could not truthfully say that the smell was really a bad one. Of course there are a few really very bad smells among growing things, evil-smelling funguses, and the Dragon Arum, and one or two other flowers, though happily bad-smelling flowers are very rare. But this myrrh-like green coral was not absolutely nasty, though to me it was horrible and even frightening. I wonder whether other people would find it the same, or whether it is a case of idiosyncrasy. Now, there is a dreadful long word, but as you will have to know what it means some day you may just as well learn now, and after all it is not a much worse word than Rhododendron, and has exactly the same number of letters. It means something that some one person feels differently from others, and in a way peculiar to himself.

Now I have told you these things only to show that one finds out a great deal about flowers and plants by smelling them, and that it is one of the most important ways of getting to know them. Then it is not flowers only but also leaves and even stems of 
plants. You know the delicious smell of the leaves of Sweet Verbena and the sweet-scented Geraniums. Then there is Balm of Gilead and one of the dwarf Rhododendrons, and Bog Myrtle and Candleberry Gale and the true Myrtle. The leaves of all these shrubby things are sweetest when they are bruised.

It seems a loss when a flower has no smell, like the lovely Kalmia. This beautiful bush was one of the treasures of the old home shrub-garden. The beauty of the flower was always an unending delight. When June came I used to look out eagerly for the red-ribbed buds that soon opened out into the wonderful fivepointed, rose-flushed flower. Each point keeps its outer colouring of purest rose, and the whole flower is a pink-white of a clean, clear, and most charming quality. Outside there are ten little knobs or shoulders, one exactly below and one between each point. You will see how these knobs give character to the flower. When you look inside you see that they are ten little hollow caves, in which the anthers on the ends of the stamens rest, and that just above each cave is a tiny spot of crimson colour, strongest above the hollows that come under the points, and much fainter (sometimes wanting altogether) in those that come under

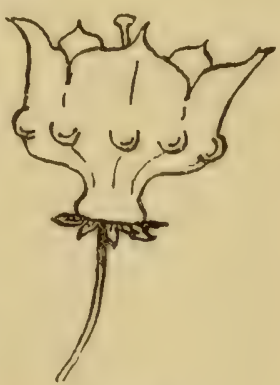

KALMIA. the cuts where the edge of the flower is lowest. Then you will also see the loveliest little zigzag ring of colour close down to the throat, each upper point of the zigzag corresponding exactly with the stamens lying across 
it. The Kalmia stamens are also sensitive, and will close up to the pistil if they are touched, though they do not do it quite so readily as the Barberry. When you first look at the Kalmia flower you think it has a quite smooth surface, but if you look at it closely outof-doors in the sun you will see that it has tiny whitish hairs all over the outside, and, among them and on the inside too, little glistening points like the tiniest diamonds.

Now if you will take any flower you please and look it carefully all over and turn it about, and smell it and feel it and try and find out all its little secrets; not of flower only but of leaf, bud, and stem as well, you will discover many wonderful things. This is how to make friends with plants, and very good friends you will find them to the end of your lives.

When you are looking at the leaves you should observe their shape, whether they are entive like the Kalmia, or pinnate like the Rose, or two or three times pinnate; this is when they branch out again and again, like the leaves of most of the umbelliferous plants and many of the Ferns; or whether their shape is a trefoil (three-leaf) like Clover, or linear, a long line without much width, like Pinks and grasses, or any of the many other shapes that leaves take. Then you will notice how the edge is shaped; whether it is quite smooth like the Kalmia leaf, and in that case whether the edge is flat or waved. The Kalmia is a little waved, the Sweet Bay much more waved. Then you will see whether it has some pattern on the edge. Many leaves have the edges toothed like saws, 


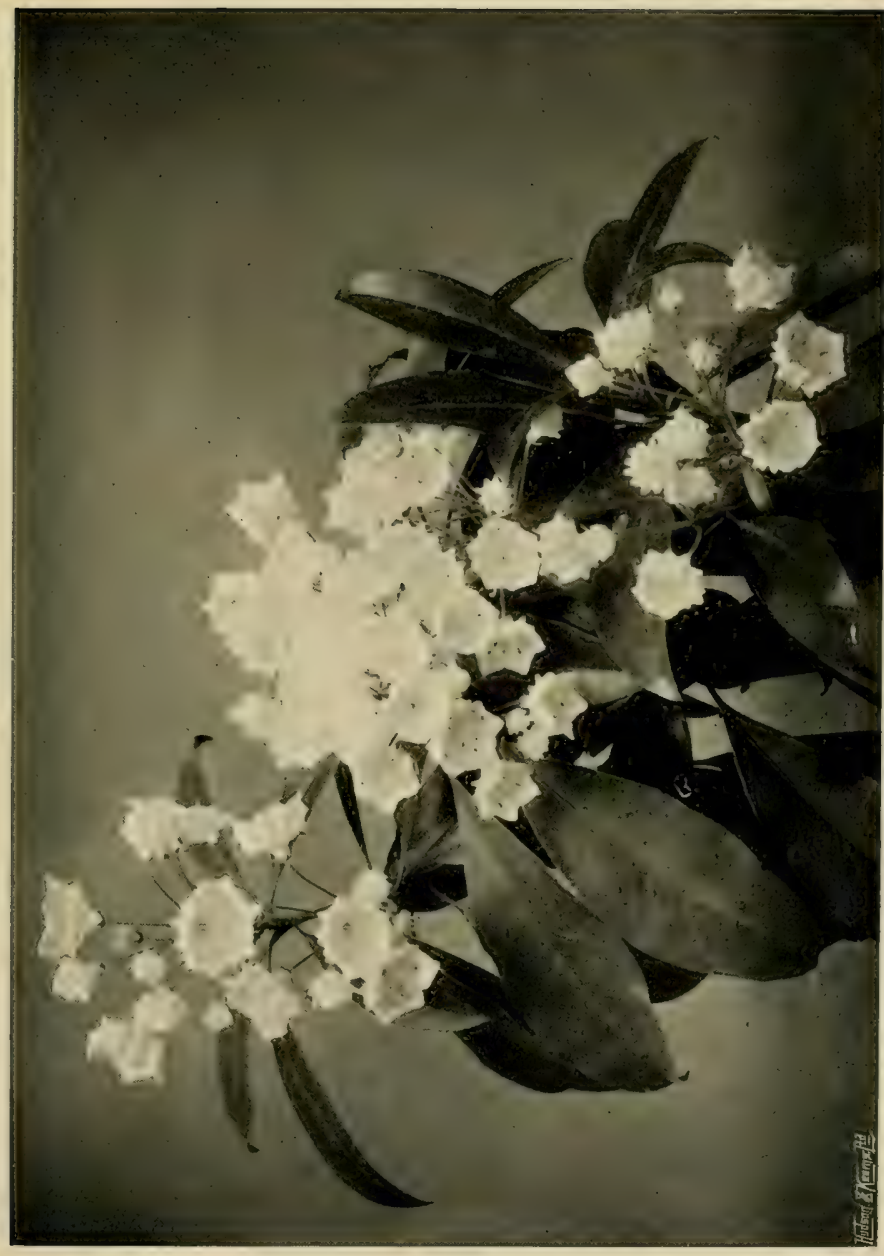

3
$\vdots$
$\vdots$ 


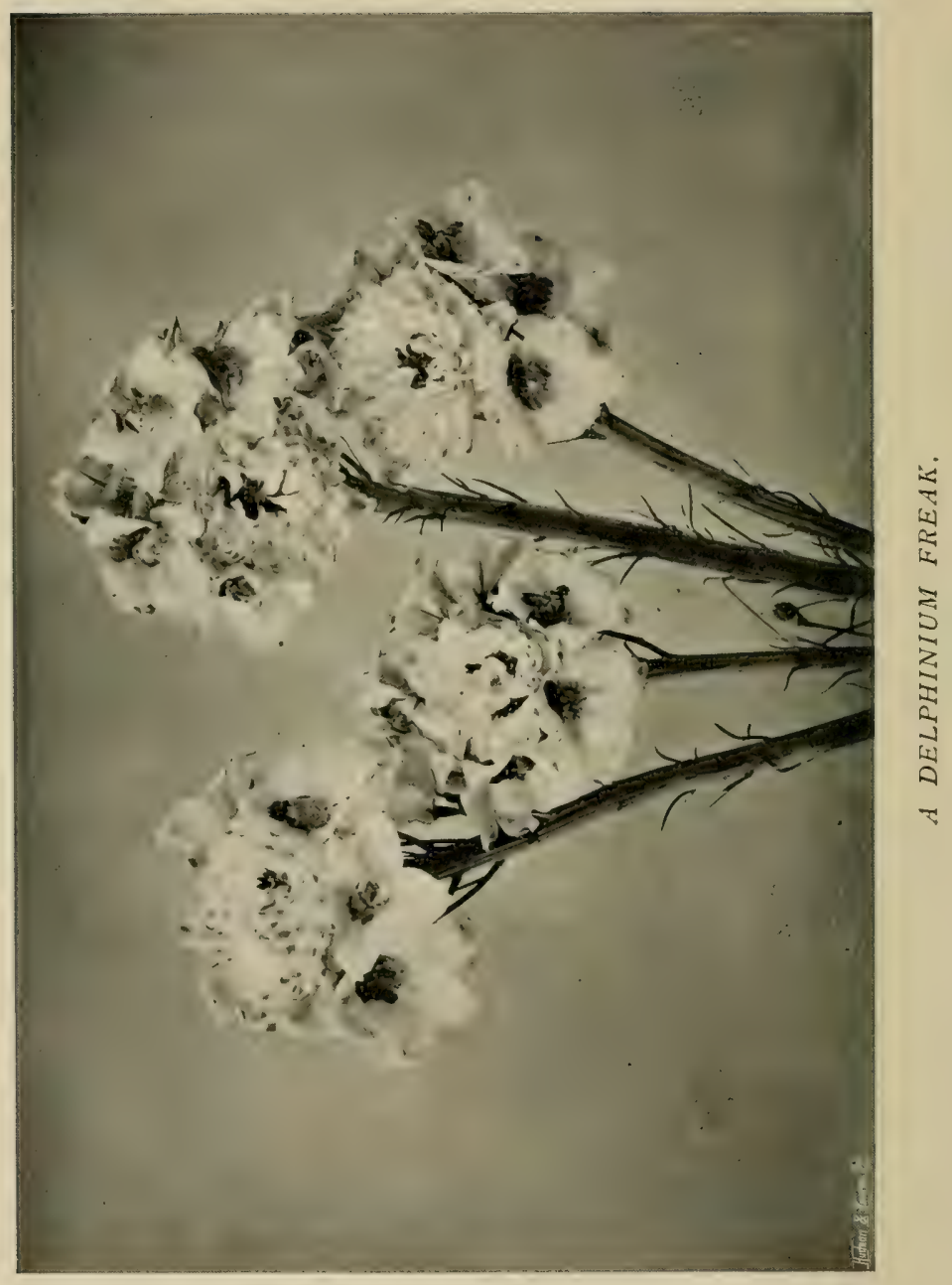


therefore the botanical word for this is serrate. And I daresay you know already that the name of the Dandelion is really Dent-de-Lion, because of the lion's teeth it has at the edge of the leaf. Some leaves, such as Violets, are heart-shaped, and these in botany are called cordate, and some kidney-shaped, and so on. Then as to surface, some leaves are polished, like Laurel, and some are quite woolly, like Stachys, and there are leaf-surfaces that represent everything in between.

Now I will not go on about details of all these different shapes and edges and surfaces, but will only say once more that the more you look at them for yourselves the more you will be amused and interested, and the better it will be for you later, when some of you will want to study botany in earnest.

When you get into the habit of watching plants and flowers closely, you will now and then come across some freak or monstrosity. Generally these flower-freaks are ugly things, like an absurd Delphinium that once grew in my garden, whose picture I have made for you, as a warning not to encourage that sort of thing. Instead of making a beautiful, tall, graceful eight-foot-long spike, the thing made a bare stalk about six feet high with an ugly bunch of crowded flowers on the top, as if the silly thing was trying to be a Rose! Foxgloves sometimes do the same. Now the whole beauty of the Foxglove is in the way the spike spires up to a graceful point, and all this is lost when the spike ends suddenly in a large, ugly cup-shaped thing like a bad Canterbury Bell. 
These ugly monstrosities, which, I am sorry to say, some seedsmen sell as "desirable novelties," should never be encouraged in gardens, for we should do all we can to teach our eyes to see what is the most beautiful form and most beautiful colour that any of our garden flowers can take.

The only kind of freak-plants that I don't much mind are the Hen and Chickens Daisy, that has a whole circle of little Daisy-flowers on stalks growing out of the edge of the main Daisy, and is certainly an amusing little thing to see now and then; and some

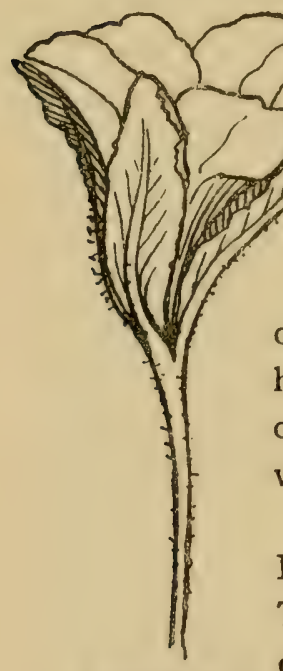
of the Primroses that grow with a leafy calyx, like the one I have drawn for you that was found in a wood by some children neighbours of mine. But this leafy thing is not half so pretty as a common Primrose. If it was the other way about, and Primroses in general had these leafy calyxes, and then one day one found among them a true Primrose, what a beautiful thing we should think it!

Freakish forms also occur among fruits. Look at these shocking pear monstrosities. Think of the lovely shape of the pear debased into these ridiculous blobby forms, PRIMROSE WITH
LEAFY CALYX. with wretched little leaves coming out of them. It is curious and interesting to see, just now and then, but one is so sorry for a poor fruit that, instead of showing its own beautiful lines takes these useless and ugly freakish shapes. 


\section{SMELLS AND SHAPES}

But there are many curious things that are natural to plants and are not ugly; such as the little complete plants that come upon the fronds of one of the green-

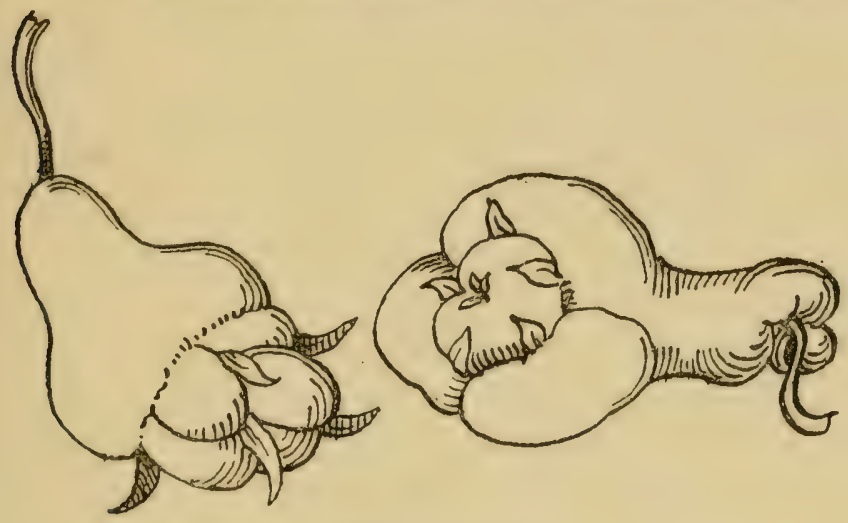

DEFORMED PEARS.

house Ferns, and the reserves of water in the pitchers of the Pitcher-plants (Nepenthes), and hundreds of other wonderful things that you will see and find out if you use your eyes and brains well. 


\section{CHAPTER VII}

\section{BOTANY}

Now, don't be afraid of the word "Botany." I am going to show you that it is not at all a tiresome study. Of course botany books in general are apt to be dull and dry and alarming. They frighten one by calling things names. For instance, they talk about Systems and Classes; and when you begin with Class I., Dicotyledones, they expect you to learn that this class has four sub-classes, namely: (I) Thalamiflore, (2) Calyciflore, (3) Corolliflore, (4) Monochlamydea, and so on through twenty different classes; all with heaven knows how many sub-classes.

Now I don't think that is at all the way to begin, and that is not $m y$ botany. But I do want you to learn my botany, which is amusing, and is quite simple and easy. Botany means classification of plants ; and when you know my sort of botany, then some day you will very likely want to learn botanist's botany, but I don't think it is any use to you just now. What does concern you to know is that the plants we know best, and want in our flower gardens and kitchen gardens, are, most of them, members of a few large families, and 


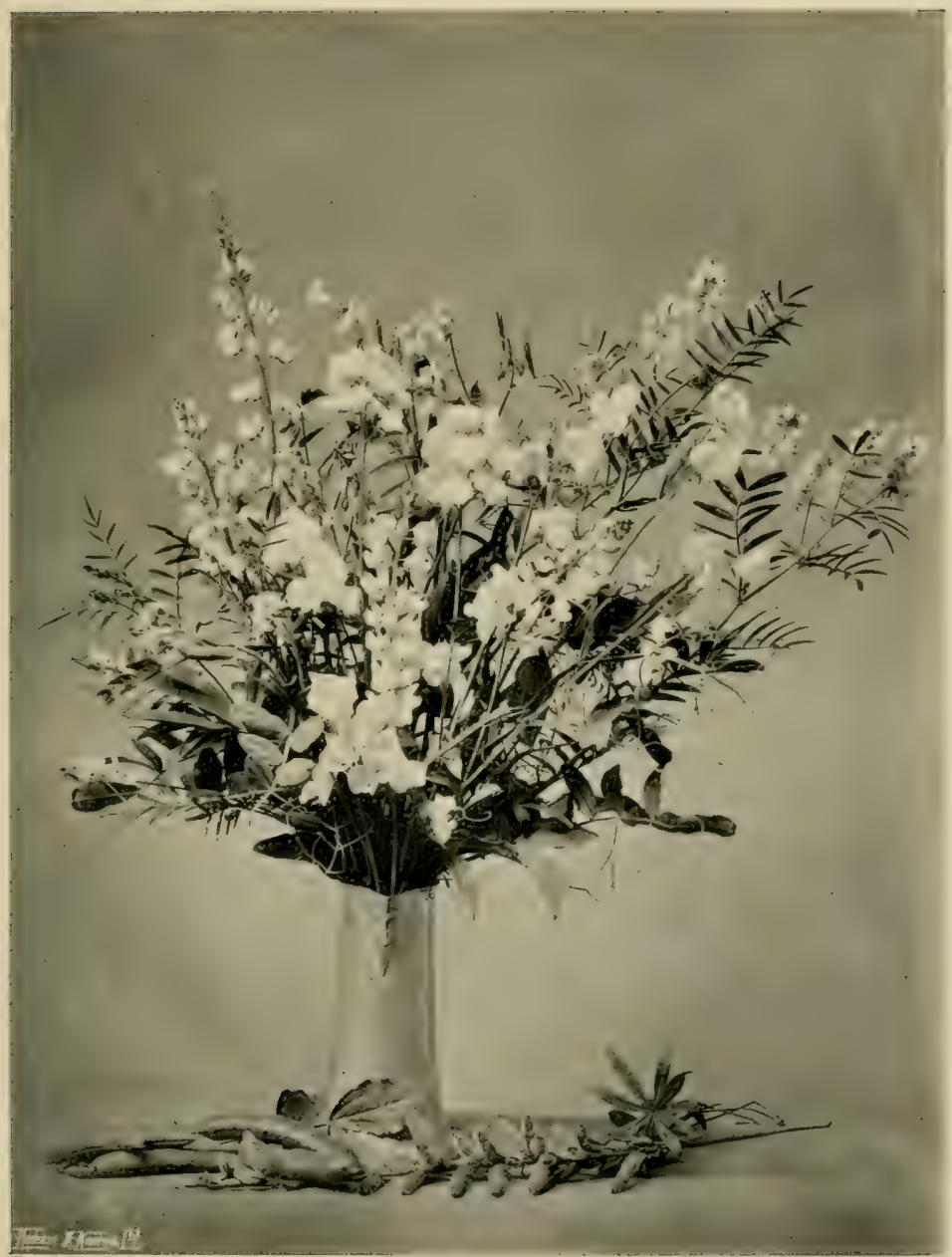

PEA FLOWERS AND PODS. 


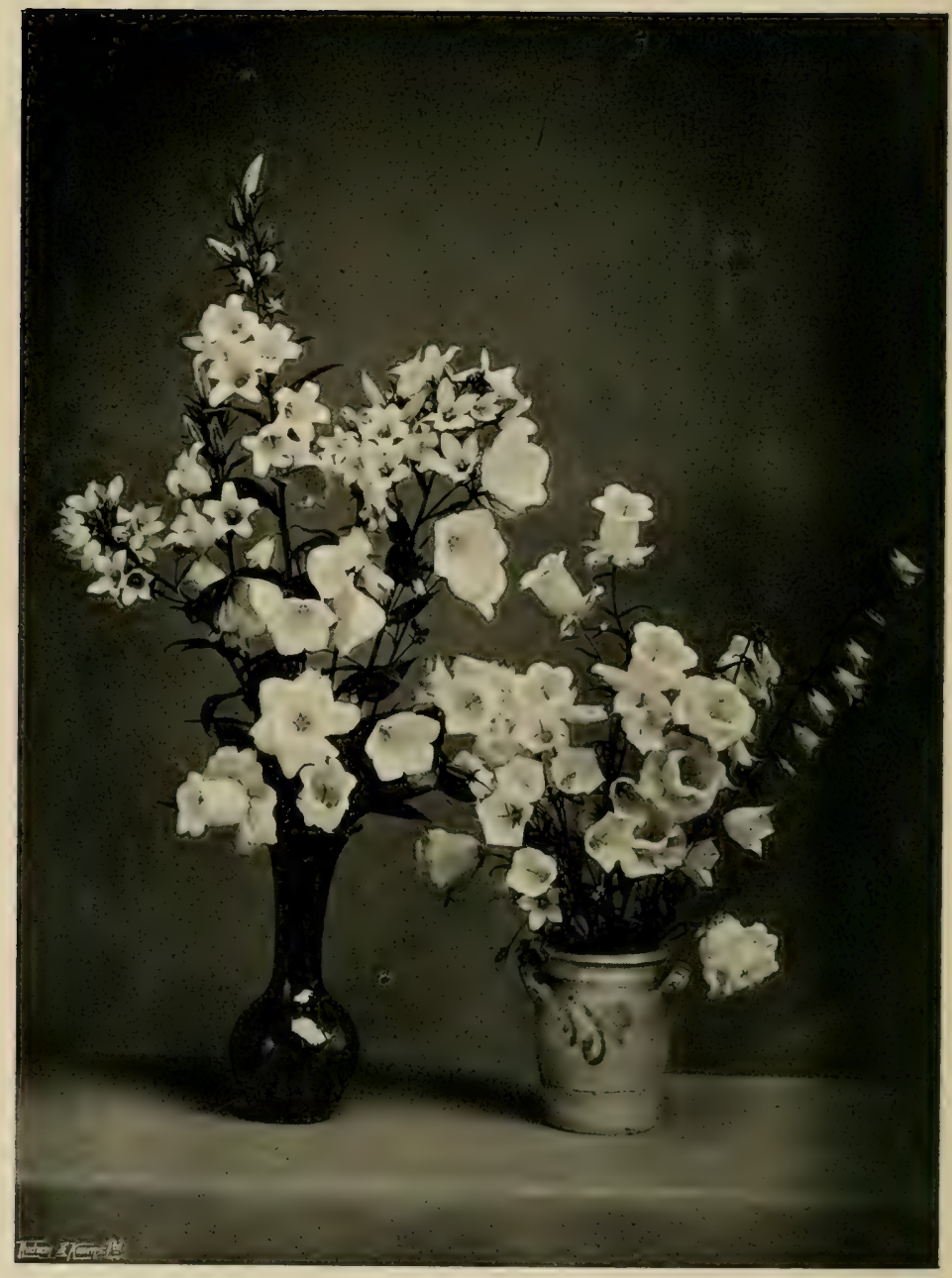

BELL-FLOWERS. 
you can know them by the family likeness of the flower.

We will begin with the Rose family. For the sake of clearness let us think of a single Rose; a Sweetbrier or a wild Dog Rose, with its five petals. You will see what "petals" and all such words mean as we go on. The petals are the five coloured "roseleaves" that fall off after the flower has been out for two or three days. Besides these, the Rose flower has an outer fringe of green leafy things, and a knobby base where it joins the stalk. The leafy bits that show between and behind the petals are called sepals. It is the outside of the sepals that you see when the flower is in bud; and all the sepals together, joined to the knobby thing next the stalk, form what is called the calyx. The knobby part will swell into the fruit. In the case of the Rose, by the end of the summer it will have grown into the Rose-fruit that we call the hip; in the case of the Apple-tree it grows into an Apple; and when the Apple is formed you can still see the sepals making a little ornament round the sunken eye. For Apples belong to the Rose family. You may easily see this by looking at an Apple-tree in flower. In some Apples the blossom is almost exactly like a single Rose. Plums and Pears and Cherries are all relations of the Rose, and so are Medlars and Quinces. Look at a bit of May-blossom (Hawthorn), there again you have a cluster of little Roses; Blackthorns too-they are wild Plums. And Strawberries, Raspberries, and Blackberries-all little Roses.

Some others of the Rose tribe are less like Rose- 
blossoms, because the flowers are arranged in flat clusters, as in the case of Mountain Ash and White Beam, or in other shaped clusters, as in the Meadowsweet, that is so pretty along the banks of streams and ditches in July and August. But whenever you meet with a flower with five petals, whether large or small, that is at all the shape of a Rose, with a short knobby base, you may be sure it belongs to the Rose tribe.

Then another of the great plant families is the Pea and Bean tribe. The Pea-shaped flowers make them easy to distinguish. There are the garden Sweet-Peas and the kitchen-garden Peas, and Broad Beans and Runner Beans, and the Everlasting Pea, and in fields and wild places the Clovers and Vetches. It does not matter whether the flowers are large and only two or. three together, as in the Sweet-Pea, or whether they are tiny and arranged in a round head, like the Bird'sfoot Trefoil, or in a crowded head two inches long, like the beautiful purple Tufted Vetch, or set all along long branches, as in the Broom ; you will see that the general shape of the flower is always the same.

Now I will not attempt to go through all the plant families, but will just show you one or two of the others that are among the most important.

There are the Composites or Daisy flowers, with a middle of tiny little flowers of one short kind packed close together, generally flat and yellow, but sometimes of other colours, and a little bit raised, or even quite raised up like a thimble. This part is called the disc. Then all round are the rays, which are of long shape. Think of the common Daisies of our lawns, and the 
Ox-eye Daisies of the fields, and you will see that they are as I describe. There are some exceptions to this arrangement, but we need not bother about them. What concerns us now is to learn the broad distinctions.

Then there are the Bell-flowers or Campanulas, so distinct that it is impossible to mistake them; Canterbury Bells and wild Hare-bell, and all the flowers of that shape.

The Cruciferce or cross-shaped flowers you know by their having only four petals, as in Wallflowers, single Stocks, Arabis, and the Cresses.

The Labiates or lipped tribe you will soon learn to distinguish. They have mouths that you can pull open to look inside, and a hanging lower lip. Salvias belong to this, and Sage, and a number of other kitchen herbs, and Lavender and Rosemary.

The Figwort tribe, named from a common waterside plant, the Water Figwort, is the only other plant family you are likely to mix up with the Labiates, for the flowers are rather the same shape, and have mouths and lips that can be opened and shut. The Foxglove holds its mouth open, but the pretty Toad-flaxes and the Snapdragons keep theirs shut, though they are easily opened. It is amusing to see one of the small bumble-bees go into a Snapdragon flower to get the honey. He has to shove it open with his head and then works himself well inside. Then if you have got any little tool or a bit of stick in your hand, just hold it for a moment under the lip of the flower to keep it shut. Very soon he will have got all the 
honey he wants, and will try to back out. When he finds he can't he gets into a regular rage, and buzzes in a very angry way. You must let go after a moment, because after all he is about his rightful business, and it is only justifiable on your part to thwart him for an instant-perhaps not at all. But it is certainly amusing to see how short his temper is.

But this is not Botany; it is Natural History, though of course the two sciences are closely allied.

There is just one more of the important families of plants that you will very soon learn to recognise. They are called the Umbelliferce. You will see more of them in the hedges than in the garden, but if there is a big bog-garden at your home I daresay there will be plants of the giant Cow-parsnip, the biggest of the umbelliferous things. All the Parsley-Carrot-Fennel sort of plants have their flowers in umbels. The flowers in themselves are generally tiny, and mostly white and yellow. They are on a number of little stalks that all branch away from one point on the top of a larger stalk, so that sometimes they make a roundish head and sometimes a flat one, or anything between. You may always know the flower of the wild Carrot by its having in the middle of its head of white flowers one little one of a chocolate-red colour.

Now, I think this is nearly all the botany we want for the present; stop, though, we mustn't forget bulbs. When you see a plant with plain, straight, rather fleshy leaves coming up from the root, and an unbranched flower-stem coming up from the root too, you may be pretty sure that the root is a bulb. Just think of 


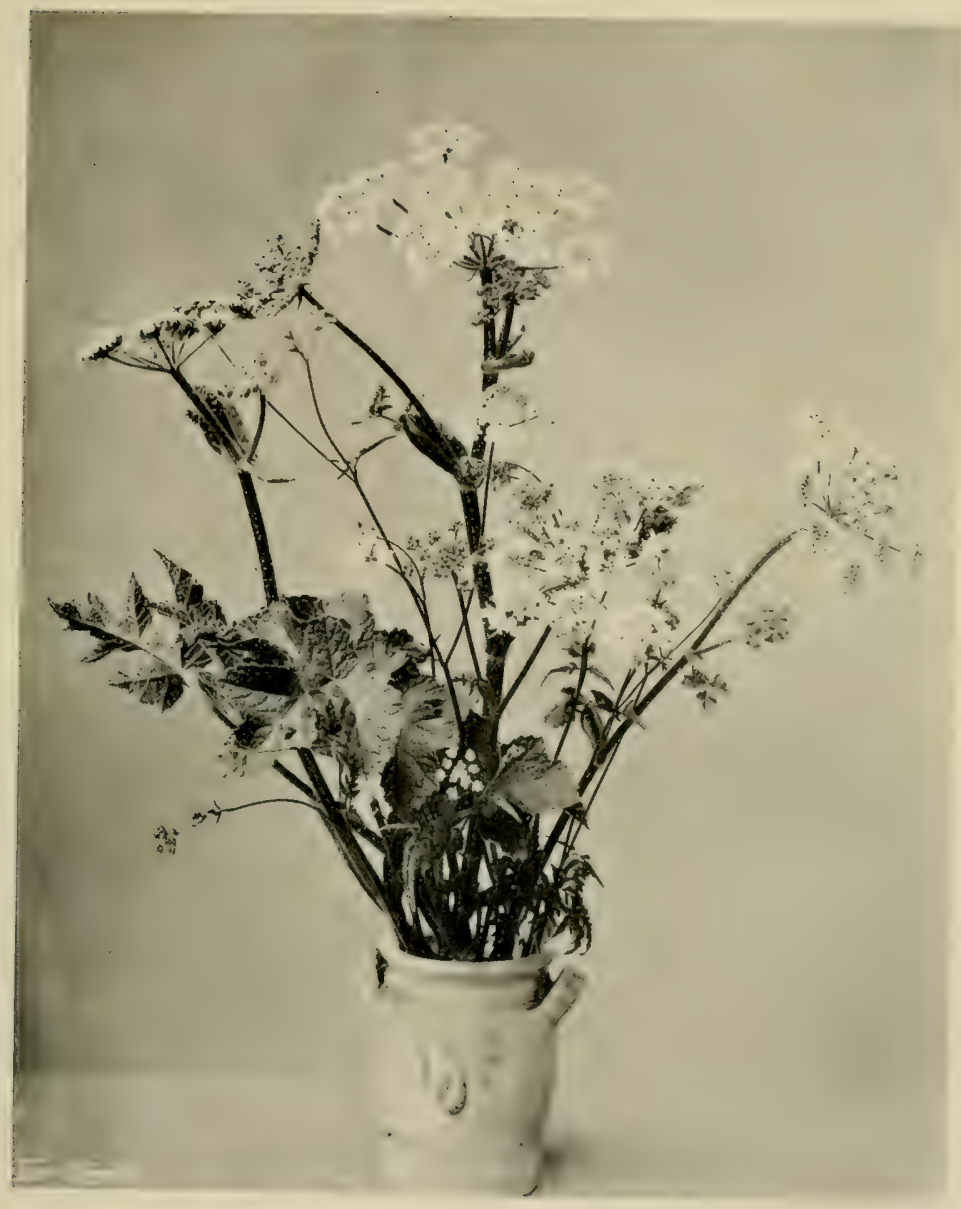

UMBELLIFEROUS FLOWERS. 


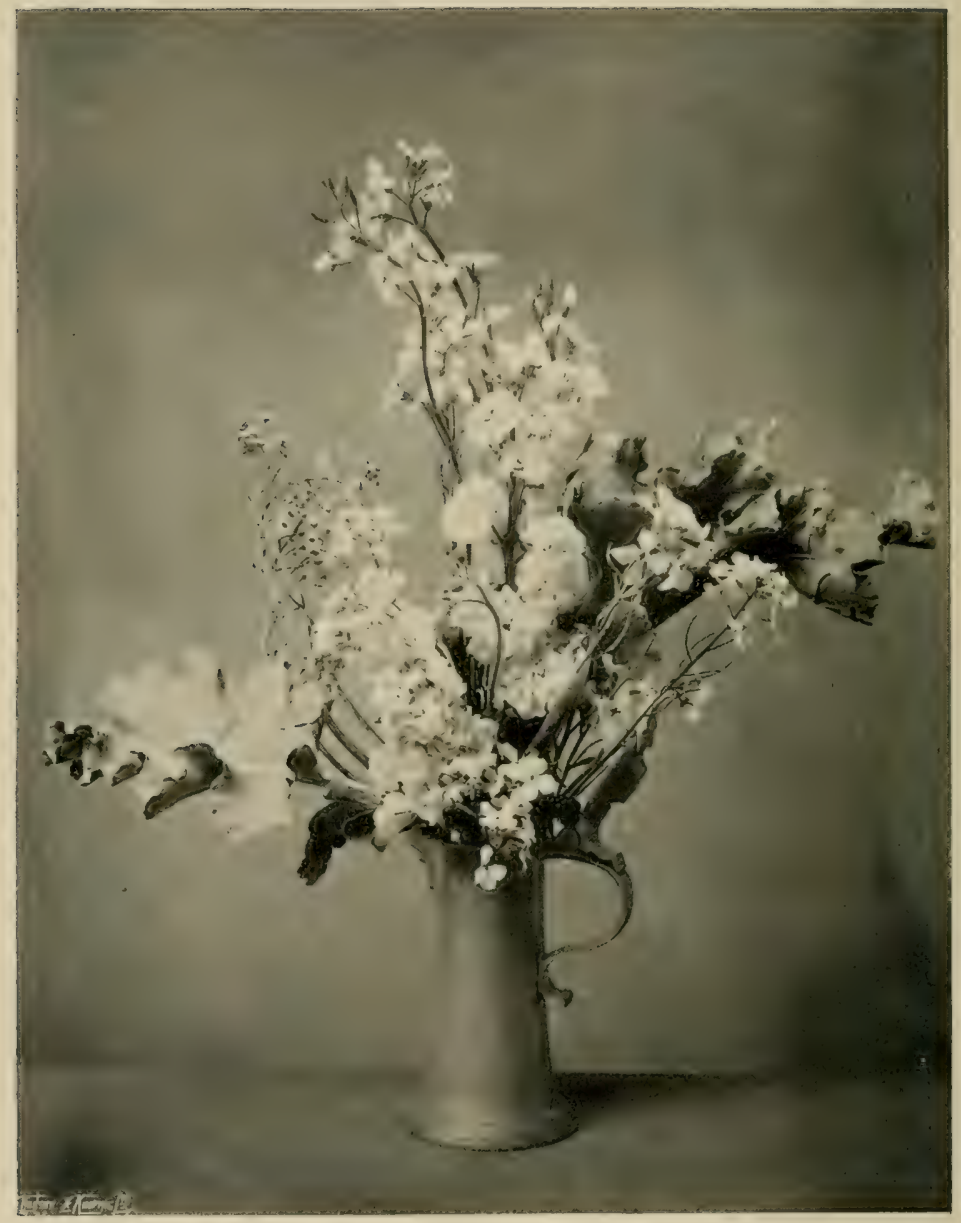

CRUCIFEROUS FLOIVERS. 
Hyacinths, Daffodils, and Snowdrops, and you will see what I mean.

Every now and then you have a birthday. I advise you, the next time somebody says, "What would you like for a birthday present?" that you answer: "Please I should like Johns' Flowers of the Field." This is not a book of garden flowers but of wild flowers ; but, if I were to try and think of the three books that throughout my life have given me most pleasure and profit, this would be one of them. You can learn about garden flowers from the wild flowers you find in your daily walks, and be learning my sort of botany all the time; because, if you are observant, which is one of the ways of being happy, you will want to know all you can about the wild flowers you see; and you will soon find out how many of them are near relations to garden flowers.

When I was a child I used to bring home any wild flowers I found and look them up in Johns. Many a time I came to something puzzling, but I never gave it up till I had found my flower in the book; and the trouble it took, though it was quite a pleasant trouble, helped to fix it in my memory.

Jean and Ann, who are resting from the labours of lesson-learning by doing some quiet knitting on the lawn, tell me that during their summer holiday in Lincolnshire they found two hundred different kinds of wild flowers; among them the tall pink Soapwort (Saponaria officinalis); and that their mother found a white variety of the Greater Knapweed (Centaurea Scabiosa). It was a grand place for wild flowers, and 
64 CHILDREN AND GARDENS

there was a shallow river to paddle in, and heavenly places for paddling where there was mud like thick chocolate.

I daresay you wonder why plants have got Latin names as well as English ones. It isn't only because botanists are so proud that English ones are not grand enough for them, but also because, as there are botanists of all nations, it is convenient that they shall all know the names of the plants in one language. 


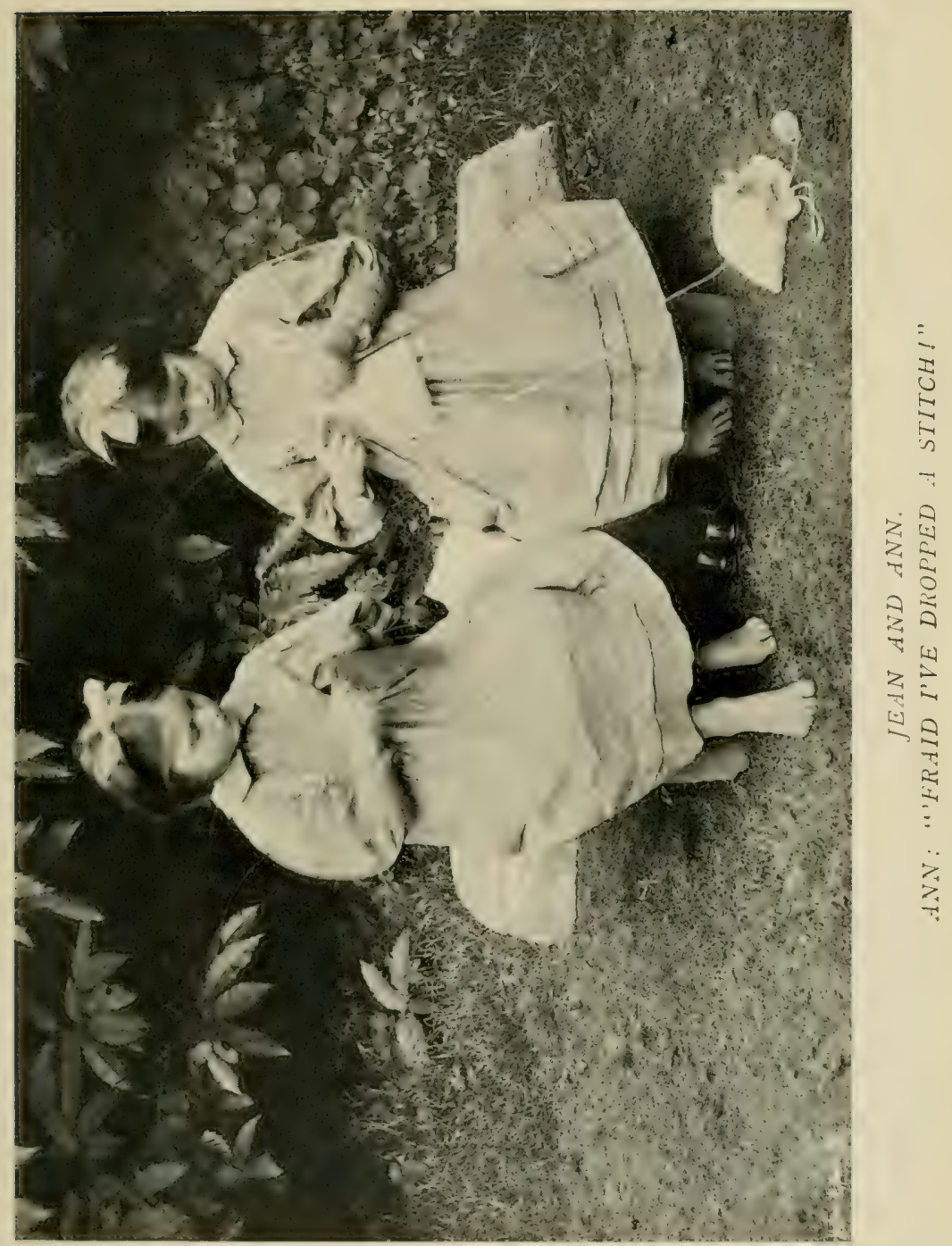




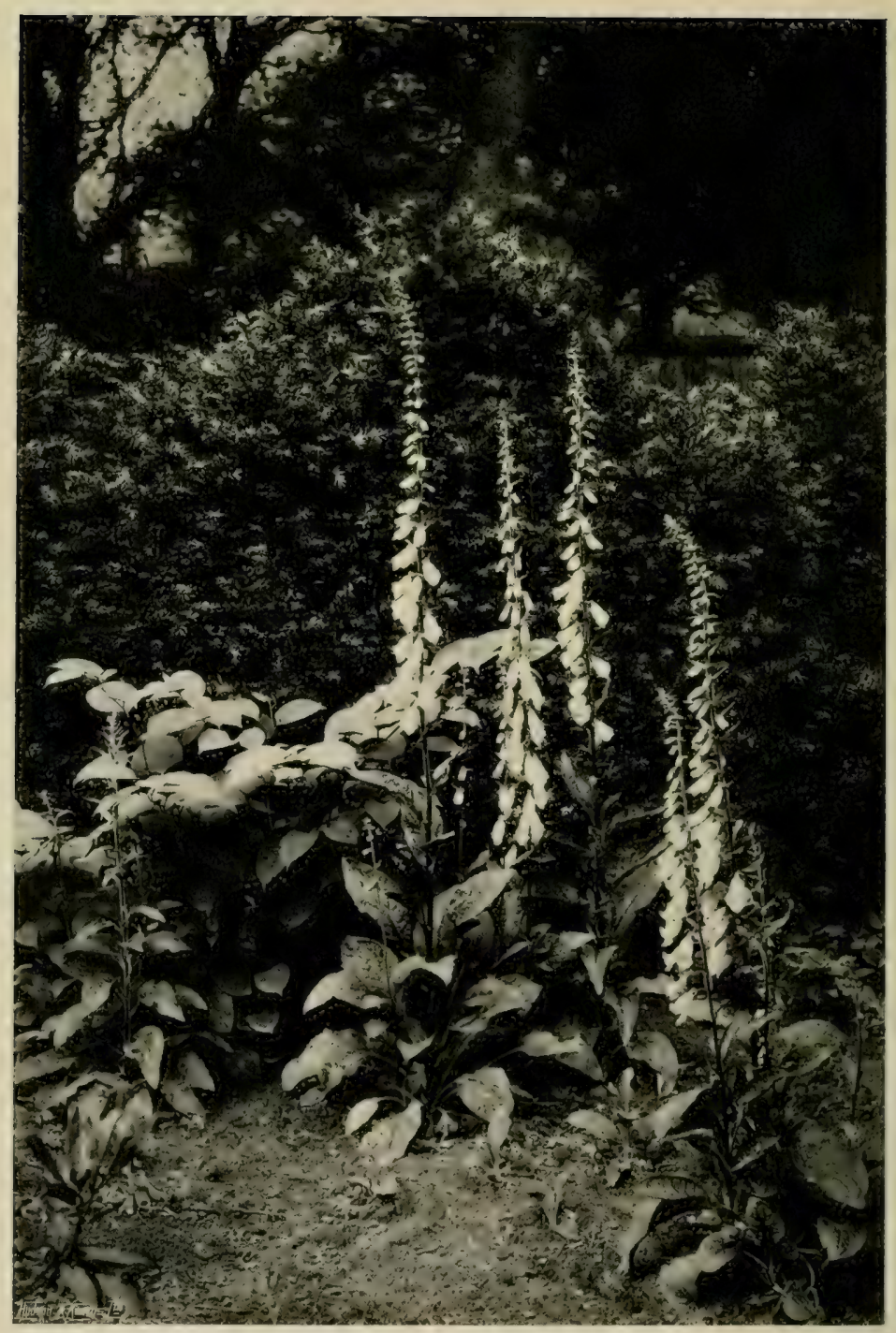

WHITE FOXGLOVES. 


\section{CHAPTER VIII}

\section{MY FIRST GARDEN}

GREAT was my pride and delight when I was first given a garden of my own, to do just what I liked with. It was in a long-shaped strip of ground notched out of the far end of the shrubberies of the big home garden, between them and a rising hedge-bank. At the foot of the bank was a shallow ditch; on the farther side a wide field at a higher level that soon began to slope upwards till it met the foot of a steep wooded hill, where we used to go primrosing. Hazels grew on the top of the bank on the field-level, and the cool face of the bank was a grand place for Ferns and Foxgloves, Primroses and Columbines. This was a great gain to my garden, for big clumps of the hardy Male Fern form a delightful background for flowers, and they are in beauty the whole summer and autumn, and even far into the winter. Here is a plan of the garden, or rather of the two gardens, for mine and my sister's were together, end to end. The arrangement is very simple, but, considering the space and position, I do not think it could have been laid out better. The narrow borders had neat Box edgings. I am sure you 
will understand the plan, because a plan is the same thing as a map, and you will have learnt to use a map in the schoolroom. But I will tell you something more about plans presently.

The plan shows how the little gardens lie between the shrubbery and the field. One of the shrubbery paths, or rather, one of its many grassy ways, comes in from the south just at the seat and arbour of my sister Carry's garden. Then the gravel path turns sharp to the right, passes first her garden and then mine, and goes on to farther masses of shrubbery and plantation, finally turning round and coming back towards the house, which is a good way off. The planted borders are shown by the diagonal lines that in plans are called "hatching" or "hatched lines."

In the spring we had Primroses and Forget-menots, yellow Alyssum, white Arabis and Aubrietia, and a few patches of the common double yellow Daffodil. This was fifty years ago, when the great numbers of beautiful sorts of Daffodils that we have now were, with but few exceptions, unknown in gardens. Another spring flower that I remember was the little purple Corydalis that comes and goes so quickly. Now that we have such quantities of beautiful kinds of flowers this old cottage-garden plant is generally forgotten, but I have always loved its modest, rather dull purple flowers, and its funny, nearly round, bright yellow bulby roots. I don't remember that we had any Tulips in our gardens, but, like many of the other bulbous plants that are so easily to be had now, they were not 


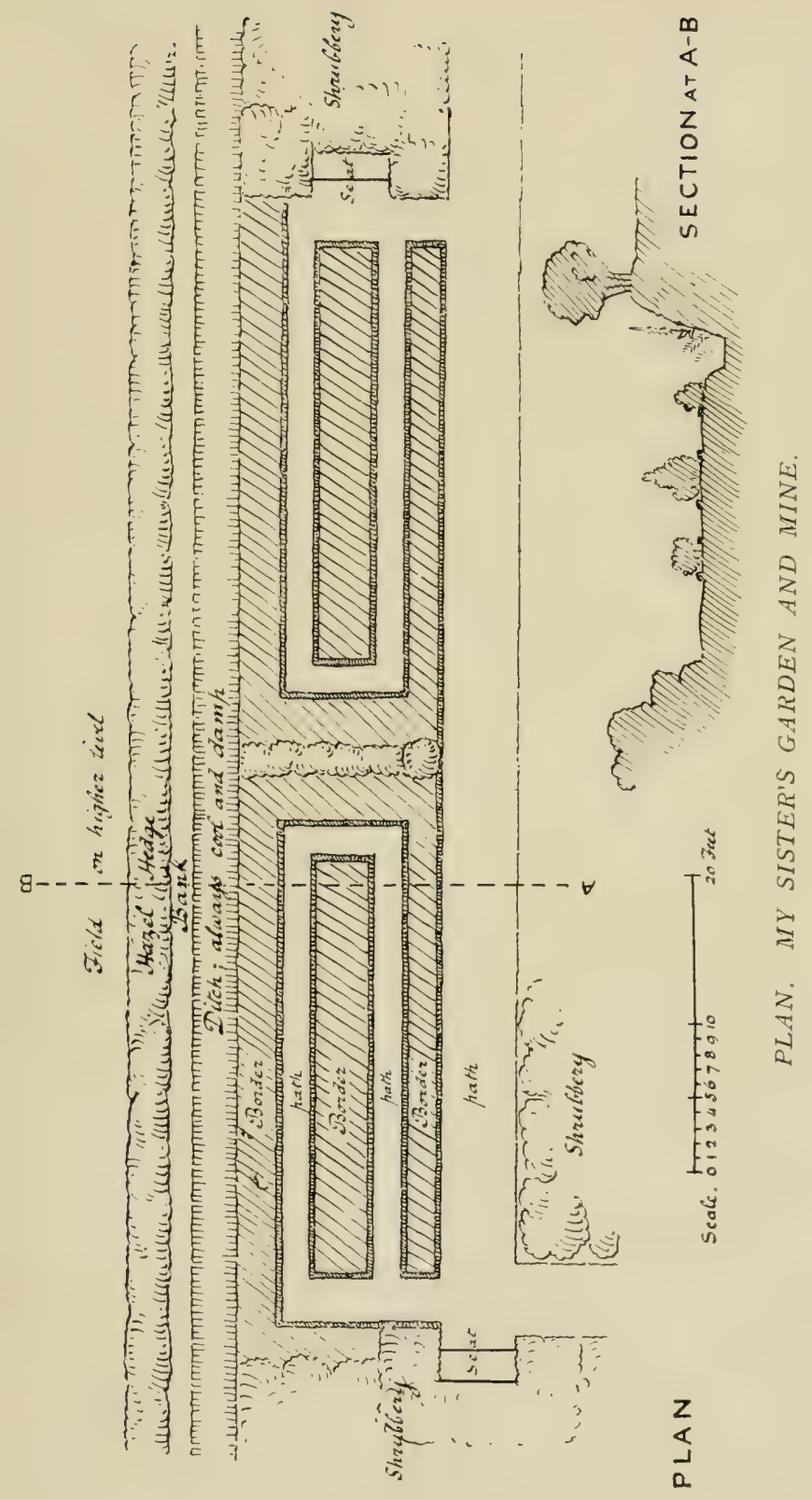




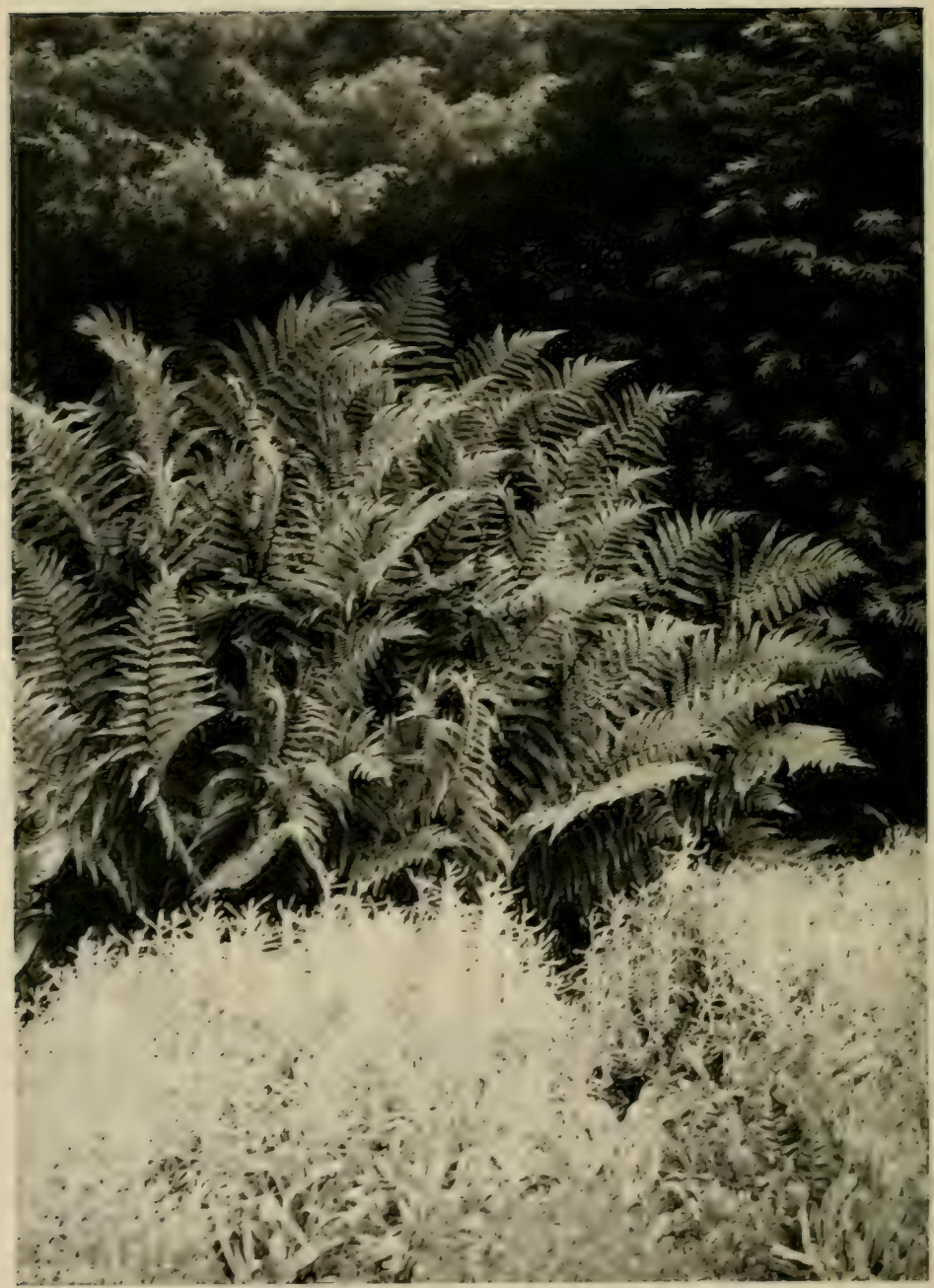

IIALE FERN IN THE COOL HEDGE. 
so freely planted, though nice patches were often to be seen in cottage gardens.

For summer flowers we had Monkshoods-a plant I should never now put in a child's garden, because it is so poisonous. Then Lupines and Columbines, with annual Larkspurs and Pot Marigolds, and some of the delicious old garden Roses-Damask Roses and Cabbage and Moss Roses, and white Pinks. Over our arbour grew the lovely Blush Boursault, of the clearest pink and pinkish - white colouring of any Rose I know. In many gardens-especially in dry soil-it never has well-shaped flowers, but here they were fully developed, and the sweetest things that one could see. I used to wonder at its smooth red stems without any prickles. In those old days I did not even know what Rose it was; we were content to call it the old Arbour Rose. In the shrubberies there were two other bushy Roses that I did not then know by name, but that I now know to be Rosa lucida and the double Cinnamon Rose; and there were sweet Azaleas and Magnolias, and thickets of the old purple Rhododendron, and various evergreens.

The two little gardens were separated by a hedge of Sweet-Peas, and there was a bush of a white Rose that must have been Madame Plantier. We grew no late summer or autumn flowers, for we always went to the Isle of Wight for August and September, and I can remember that when we came back there were sad scenes of overgrowth and neglect, and it took a lot of cleaning up to make the little places tidy for the winter.

Later I was given another bit of ground close by. 
It was more a general messing-place than a garden, though I grew some lettuces and radishes and mustard and cress, and did a great deal of work that had not much result, but was absorbingly interesting to the solitary worker. It was only a few yards behind my flower garden, and had the same hedge for its southern boundary. On the west was another hedge-bank standing up high - I should say nearly six feet-above the ground-level. It was not only high but thick; about four yards across. Hazels and biggish Oaks

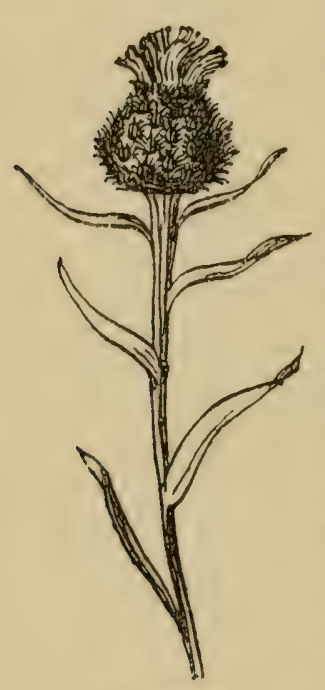

HARD-HEAD. grew in it, and there were clumps of Brambles where pheasants used to make their nests. In one part of the hedge there was a thick growth of the Black Knapweed or Hard-head that you play "Soldiers" with. It is surprisingly tough in the stem and hard in the head. There was a peaty ditch on my side, with a slight drain of water from the higher ground, but never enough to run. It was one of my delights to scramble up into the high hedge and jump down across the ditch into my garden. Just at the corner, at the angle where the two hedges met, there was a wider place in the ditch, and I was always digging out the black peaty mud to make a place deep enough to fill my watering-pot. On the other sides, away from the hedges, there were high old Laurels, great places for 


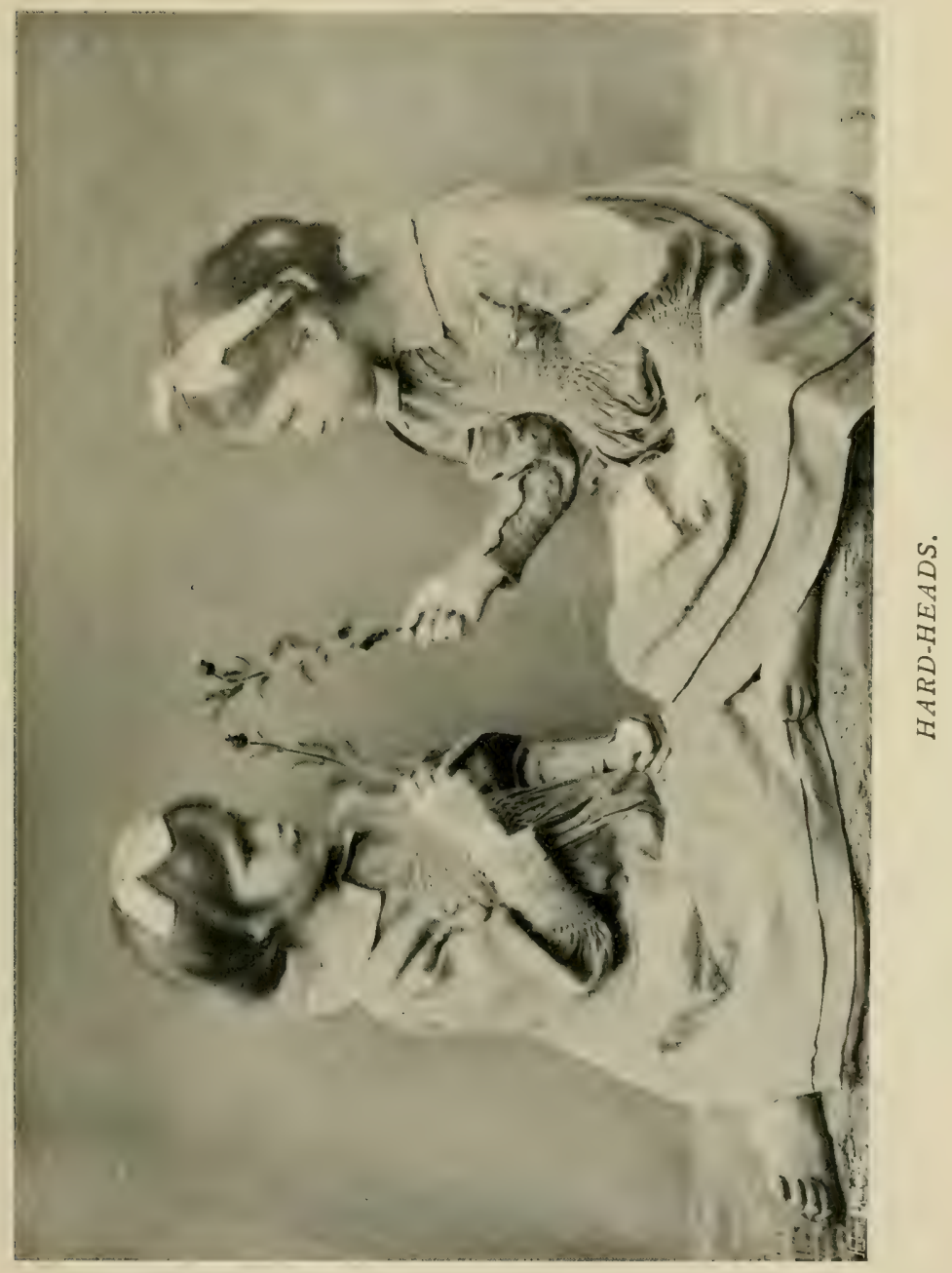




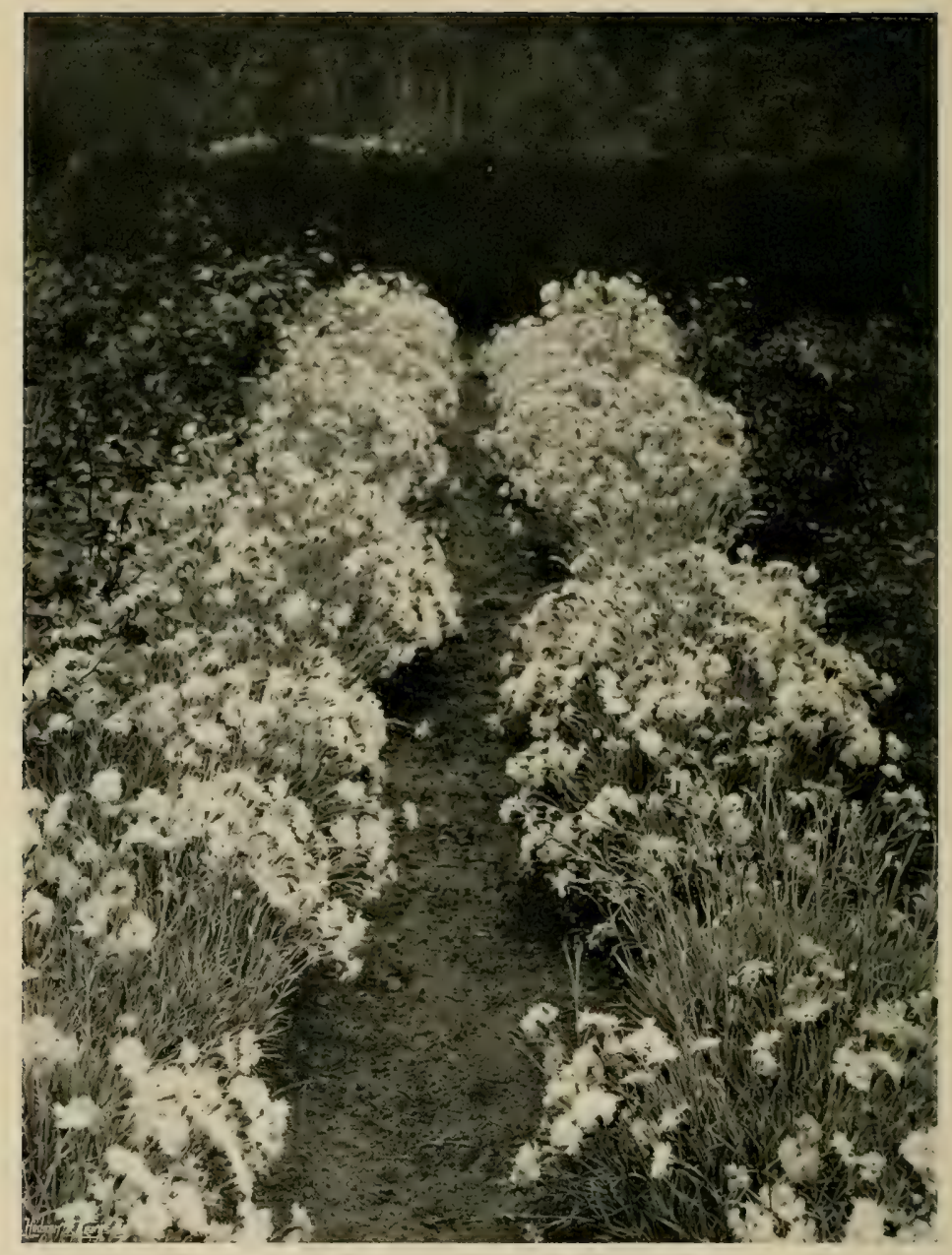

EDGINGS OF WHITE PINKS. 
blackbirds' and thrushes' nests. On one side there was a space of about nine feet between the Laurels, and here I made my hut. I did not know anything about building then, so it was simply made of supple willow stems bent over and tied, with other sticks of willow and hazel wattled in. I had read somewhere about making walls of wattle and clay, and had found a place where there was a little clay, but it was some way from my garden and in a swampy place, difficult to get at. So after digging one or two of my little barrowfuls and making a great mess of myself, so that I was not very well received in the schoolroom afterwards, I gave it up, and my hut remained a hut of branches only -in fact a sort of skeleton arbour. The only furniture was a stool I made of some bits of board. The construction was not good, and it always wobbled when I sat on it, but I soon found out how to sit very carefully, so as to avoid a

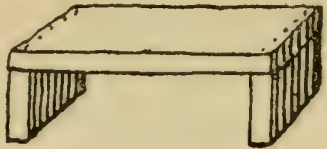

THE SEAT. collapse. If I had only known about putting in a bit on edge underneath, and nailing it through the top and at the ends, it would have been firm. Meanwhile, I used always to think that a grown-up wheelbarrow was a very comfortable thing to sit in when you were tired, particularly if you had got a cushion or even an old sack in it.

I said I would tell you about plans. A plan is a map of a small space on a large scale-you will see what scale means presently. The plan shows what it represents as if you were looking at it from above. 
If you lie on a table on your stomach and look over the edge, and if exactly below your eyes there is a dinner-plate on the floor, you see the plate in plan. But when a house is to be built or a garden is to be planned on uneven ground, you must also have a section. I have drawn a section below the garden plan to show you what it means. It supposes a cut straight through the ground. It is very seldom that such a cut is actually made, but it is a convenient way of showing levels. You see at once by the section how the field stands higher than the garden, and you see the steeplysloping hedge-bank with the Foxgloves and Ferns. If you look at the plan you will see a dotted line with the letters $\mathrm{A}$ and $\mathrm{B}$ at the two ends, and the title of the section says, "Section at A-B." This shows you where the section is taken. Then there is another point of view that is shown in drawings of buildings and in some ground-work. This is called the Elevation. It is the view of anything upright, like any side of a house when you stand and look straight at it. You do not see a thing exactly as it is drawn in the elevation, because of perspective; neither can you see things exactly in plan; but we need not bother about thatyou will see what is meant.

So to set out anything that is to be built, or groundwork that is to be shaped, you must have Plan, Section, and Elevation. In some of the pussy pictures, as at p. 106, the kittens are shown in plan, while the picture of Pinkie at p. I04 gives two elevations. If you put a cake on the floor and look at it from above, so that you see all the top and none of the sides, you see it in 


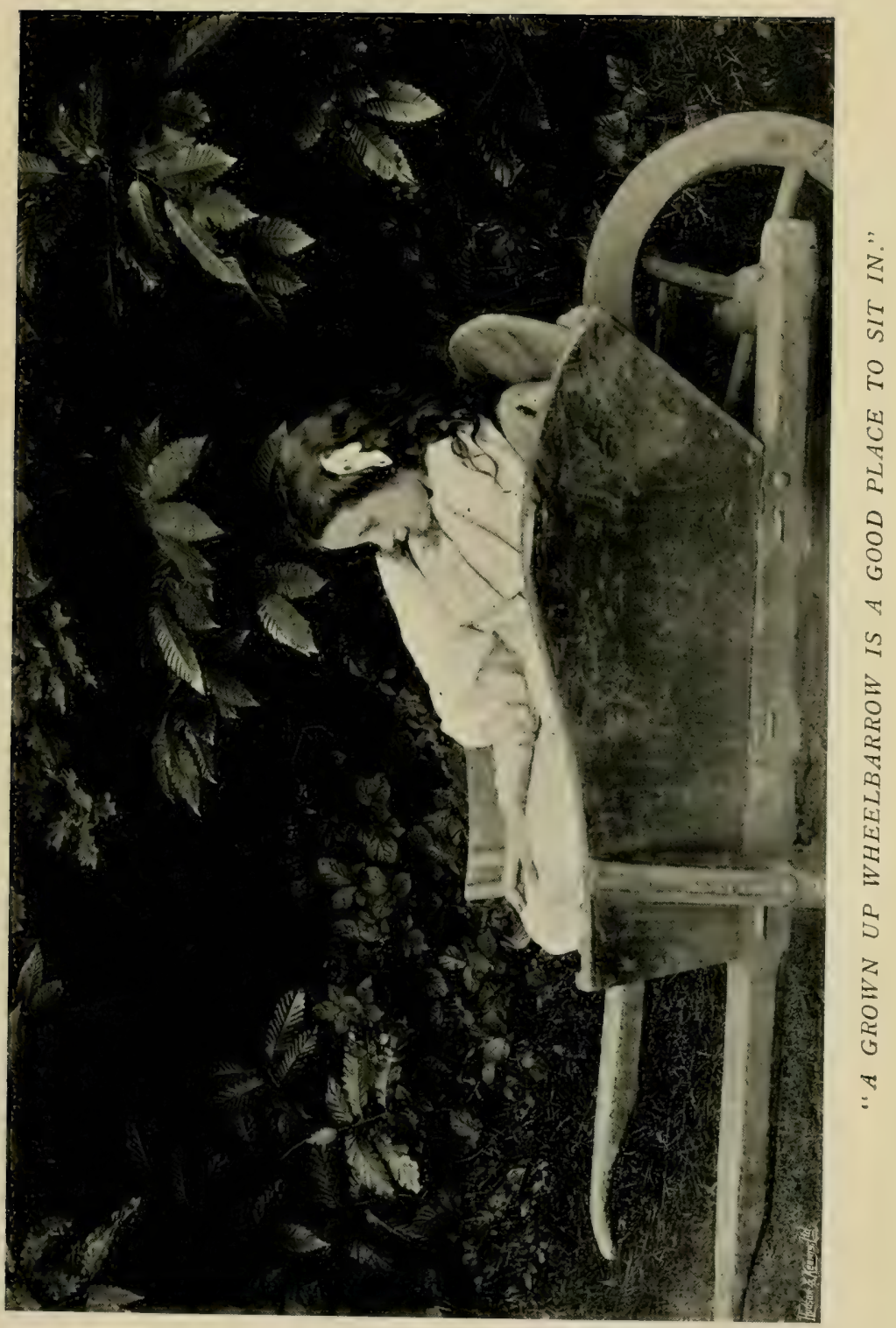




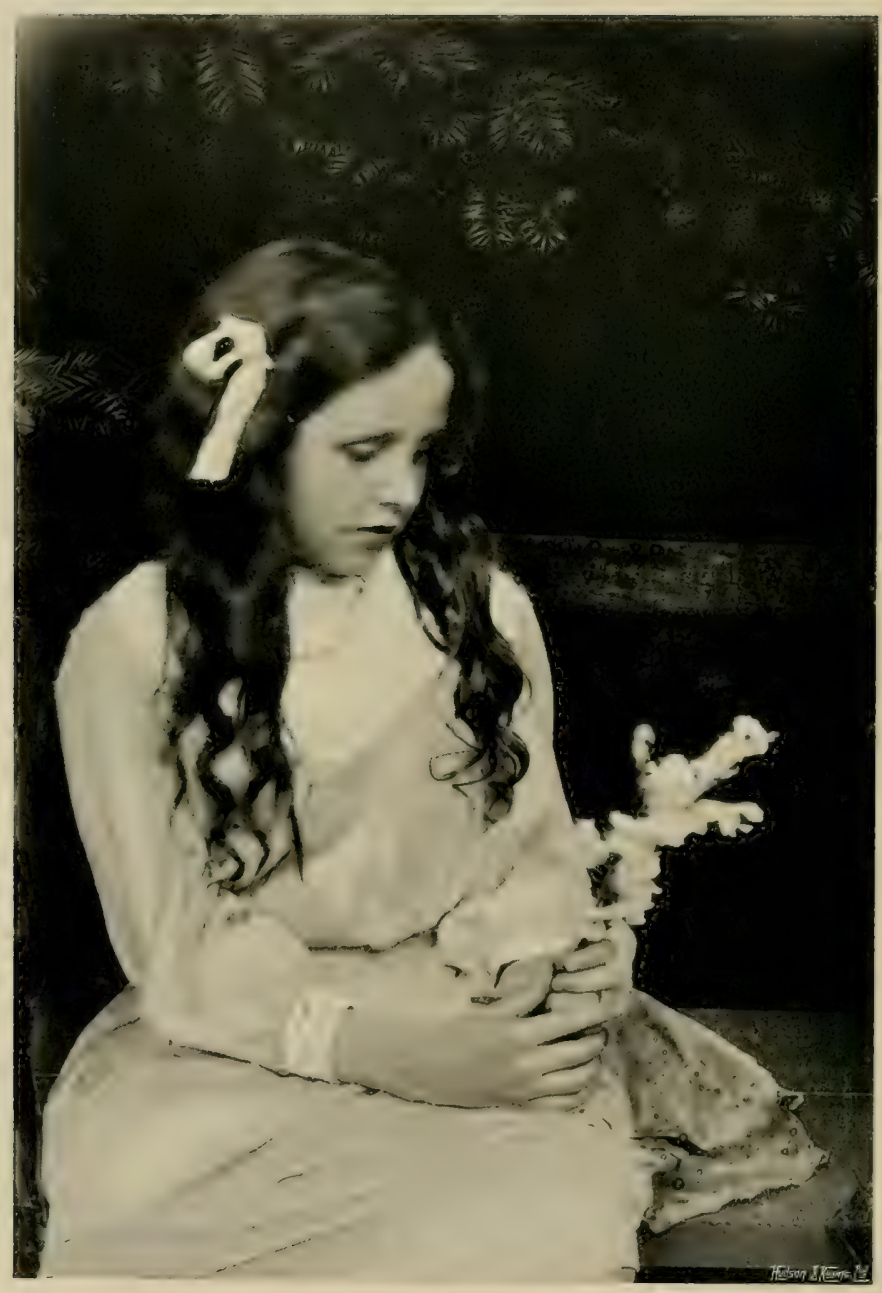

.IY BEST SNAPDRAGON. 
plan; if you stand it up on anything about the level of your eye, you see it in elevation; if you cut it in half, each cut surface shows a section. I have drawn

LOAF
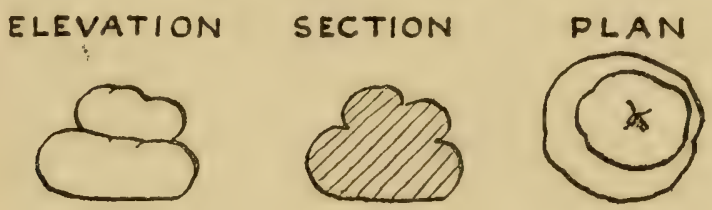

PENNY BUN
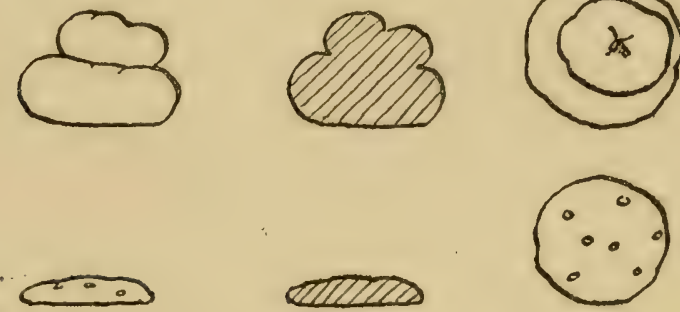

PUMPKIN
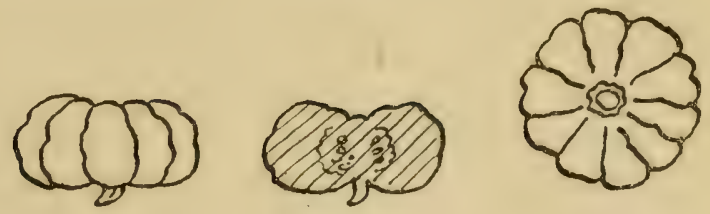

APPLE
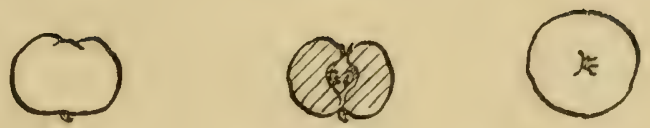

MUSHROOM
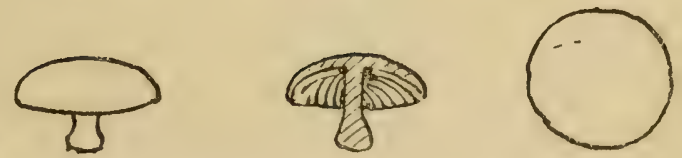

ELEVATION, SECTION, AND PLAN OF SOME COMMON THINGS.

a few well-known objects in elevation, section, and plan, so that I am sure you will understand.

Some day you will perhaps have big gardens of your own, and it will help you immensely to know about plans, and still more to be able to make them. 
But I must just tell you something about scale. There is a scale on every good plan. It is to show the relation between the size of the drawing and the actual size of the ground or house. House plans are generally done on what is called an eighth scale. That means a scale of eight feet to an inch, so that every eighth of an inch on the plan means one foot in the house. You will see inches divided into eighths on a two-foot rule.

Now I am telling you all about this because it helps so much to understand the shapes of houses and gardens when you can see what it means on a plan, just as easily as you see the counties of England on a map or the printed words on a page; and further, I am telling you about it because when I was grown up I should have been so thankful if anybody had shown it me when I was small, for I had to find out all about it for myself when I was getting quite oldish, and then it is not nearly so easy to learn new things.

I daresay many of you are learning to drawlearning freehand drawing. Making plans is called mechanical drawing, because it has nothing to do with freehand or picture drawing, and is all done with instruments and appliances, not with the hand alone. If you are wise you will ask to learn just a very little mechanical drawing, with a drawing-board and a $T$-square and a set-square, and dividers to mark off spaces, and delightful pencil compasses, with which at odd times you can make all sorts of amusing patterns. The name mechanical drawing sounds rather dull, and yet it is full of curious and amusing things. I will just tell you one, and the simple way to do it; then 
the brothers who go to school and learn Euclid will tell you the rule of it. If you want to set out what we commonly call an oval, but which is really an elliptical flower-bed, you stick two sticks upright in the ground, say eight feet apart. Then you get a piece of strong string, put it round the two sticks and tie the two ends together about a yard away from the stick nearest you when you stand just beyond the two sticks and see them in a line. Now you take another stick and hold it upright in your hand inside the string and pull it so that it tightens the string against the two sticks that stand in the ground. Then you walk round, always keeping the string tight and the stick upright, and scratch a line in the ground with the upright stick you are holding-you will find that the scratched line is a perfect ellipse. If you want to have the bed a certain length and width you must fumble about with the fixed sticks and the length of your string till you get it. This is called doing it by rule of thumb. There is another way of doing it, which is the scientific or learned way. This you must find out from the mathematical brother who understands Euclid. But the rule-of-thumb way is the most amusing-you will soon find out that the farther apart you put the sticks the narrower and smaller will be the ellipse. You can practise it at home by putting a piece of paper on a board and driving in two strong pins to represent the sticks, and using a bit of thread or stout sewing cotton in place of the string, and a pencil for the upright stick that you draw the ellipse with.

One more of these nice dodges I should like to tell 


\section{4 CHILDREN AND GARDENS}

you, because in setting out ground for garden work it is the one that is oftenest wanted. That is to find a right angle. Suppose you have a bit of straight path and you have to make a path running out of it at a right angle. You must have a strong cord with a peg at one end-nothing is better than a garden-line, because it is all ready and you can wind and unwind it so conveniently; besides both the peg at the end and the

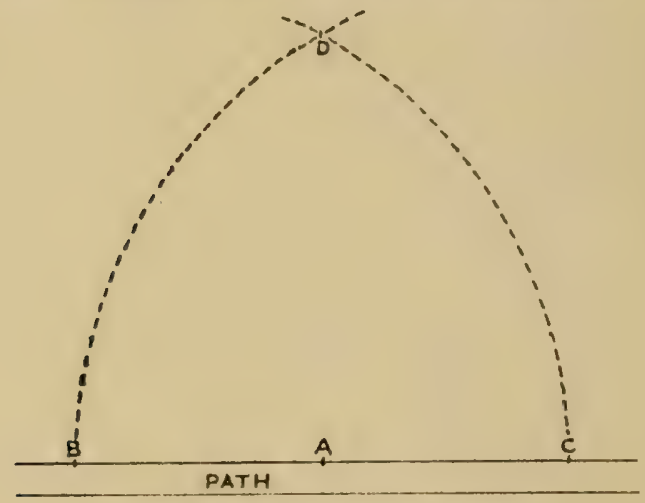

HOW TO MAKE A RIGHT ANGLE.

winder have nice points to go into the ground. First you stick the end peg into the point where the middle of the new path has to leave the old one-marked A in the diagram. Then from A you mark any length (but say about five yards) along the edge of the old path to B. Then you hold the line so that you know exactly the length from $A$ to $B$, and you carry it past $A$ to $C$. You mark both the points $B$ and $C$ with a little wooden peg. Then you pull up the end line-peg from $A$ and drive it in at $B$. Then you let out the line 


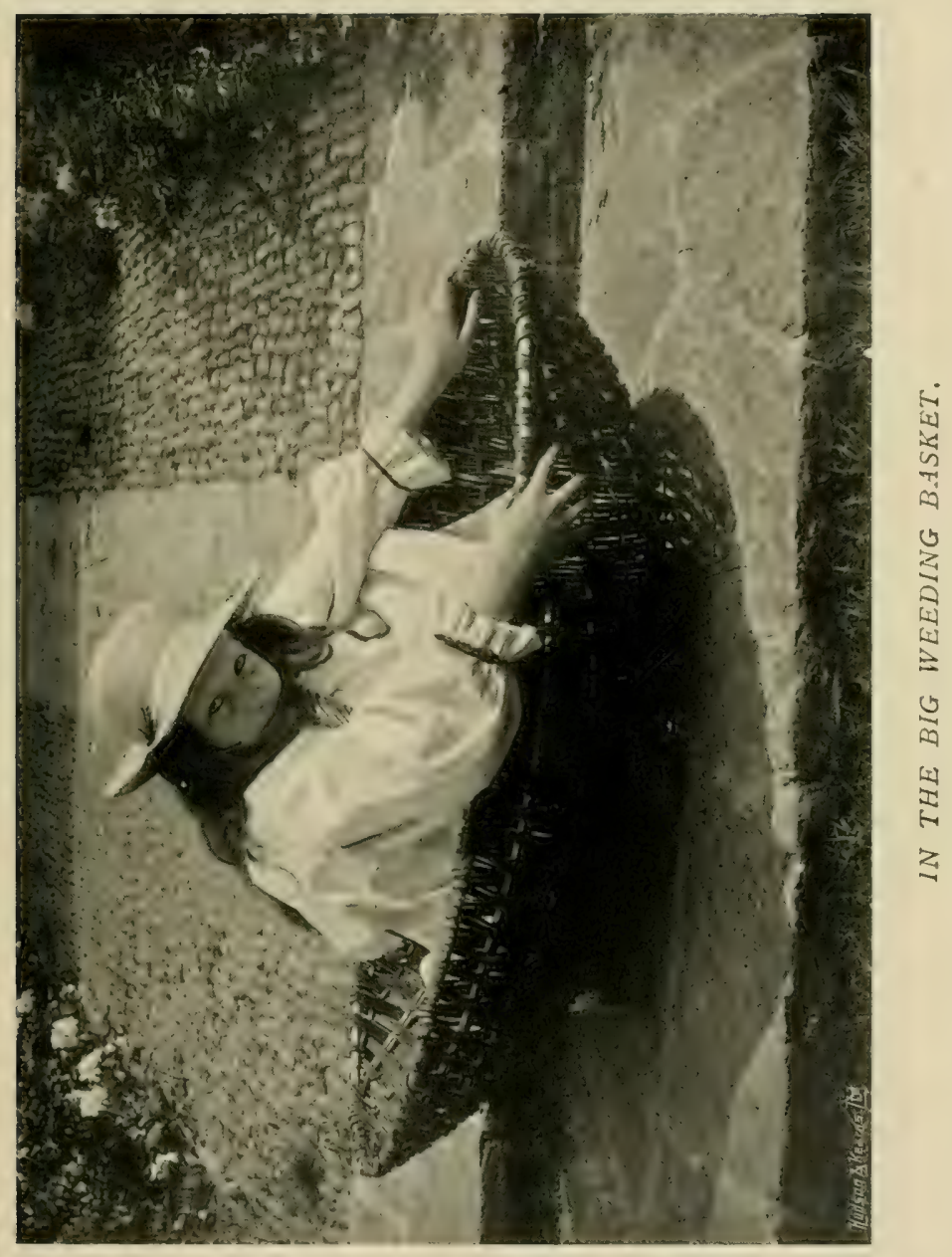




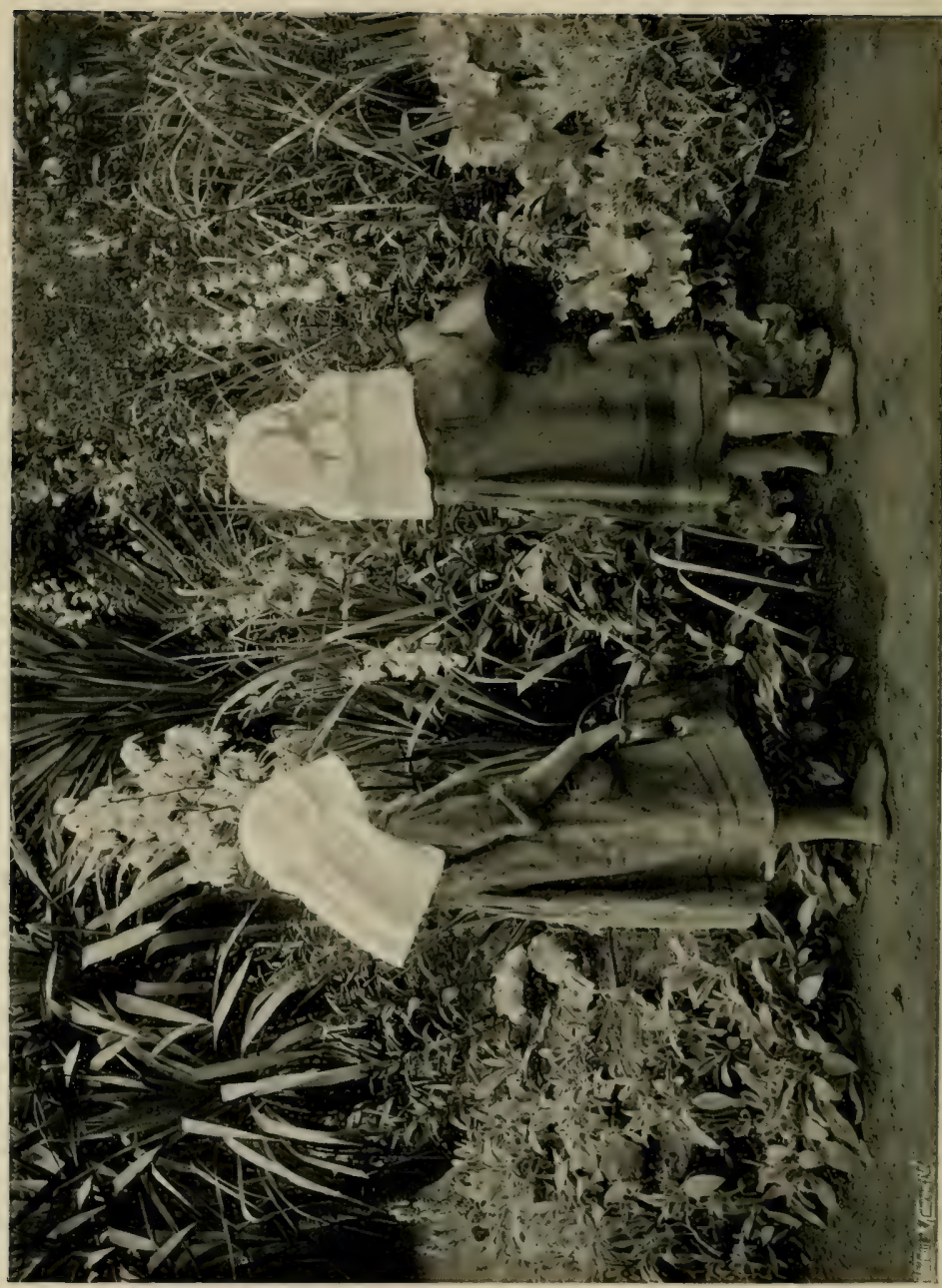

 
till it is long enough to reach from $B$ to $C$, and with the peg of the winder you scratch a curving line in the direction of $\mathrm{D}$, keeping the line tight and the peg upright as you scratch. Then you pull up the end line-peg from $B$ and drive it in at $C$, and, keeping the cord the same length as before, you scratch another curving line in the direction of $\mathrm{D}$. This point, which you mark with a wooden peg where these two lines cross each other, is an exact right angle from $A$. Now you have a peg at $A$, and another where the scratched lines cross. You go to $\mathrm{A}$ and stand behind it, and make that peg come in a line with the one at $\mathrm{D}$, and this gives you the measuring line, so that you can stick pegs straight with these two, or set the garden line, and make as long a line as you please. This is Euclid too, and you can also practise it at home with pins and thread, and easiest of all on paper on the drawing-board, with the $T$-square and set-square. There is another way of doing it out of doors with a builder's square,

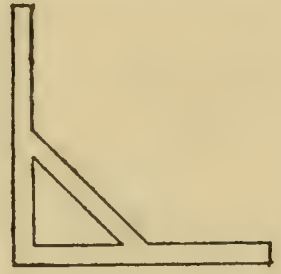

THE BUILDER'S SQUARE. - a wooden thing like the letter $\mathrm{L}$, with a brace across to keep it in shape; but unless you have a very true line to put it against on one side you are apt to go wrong. 


\section{CHAPTER IX}

\section{FLOWERS FOR YOUR OWN GARDENS}

I SUPPOSE your own garden is quite a little place, and if that is so you cannot have a great many different kinds of plants in it ; so I want to tell you what I think are just the best things for you to have. The very best gardener finds it difficult to keep one bit of garden full of flowers from spring to autumn, so it will be well if you can have some plants from the big garden, planted in the autumn for your spring display, and then taken up after flowering and put in a bit of reserve ground to be replanted in the autumn ; and to fill their places with good half-hardy annuals, such as dwarf African and French Marigolds, Ageratum and China Asters, with a few Verbenas, Heliotropes, or any kinds you like best of what are called bedding-plants, that you can beg from the gardener and plant in the beginning of June.

But you should have a few tufts of Daffodils, Crocuses, and Snowdrops, with Aubrietia, Cerastium, yellow Alyssum and double Arabis, and some of that pretty Forget-me-not, Myosotis dissitiflora. Then I should advise a few Tulips: Chrysolora (yellow), White 


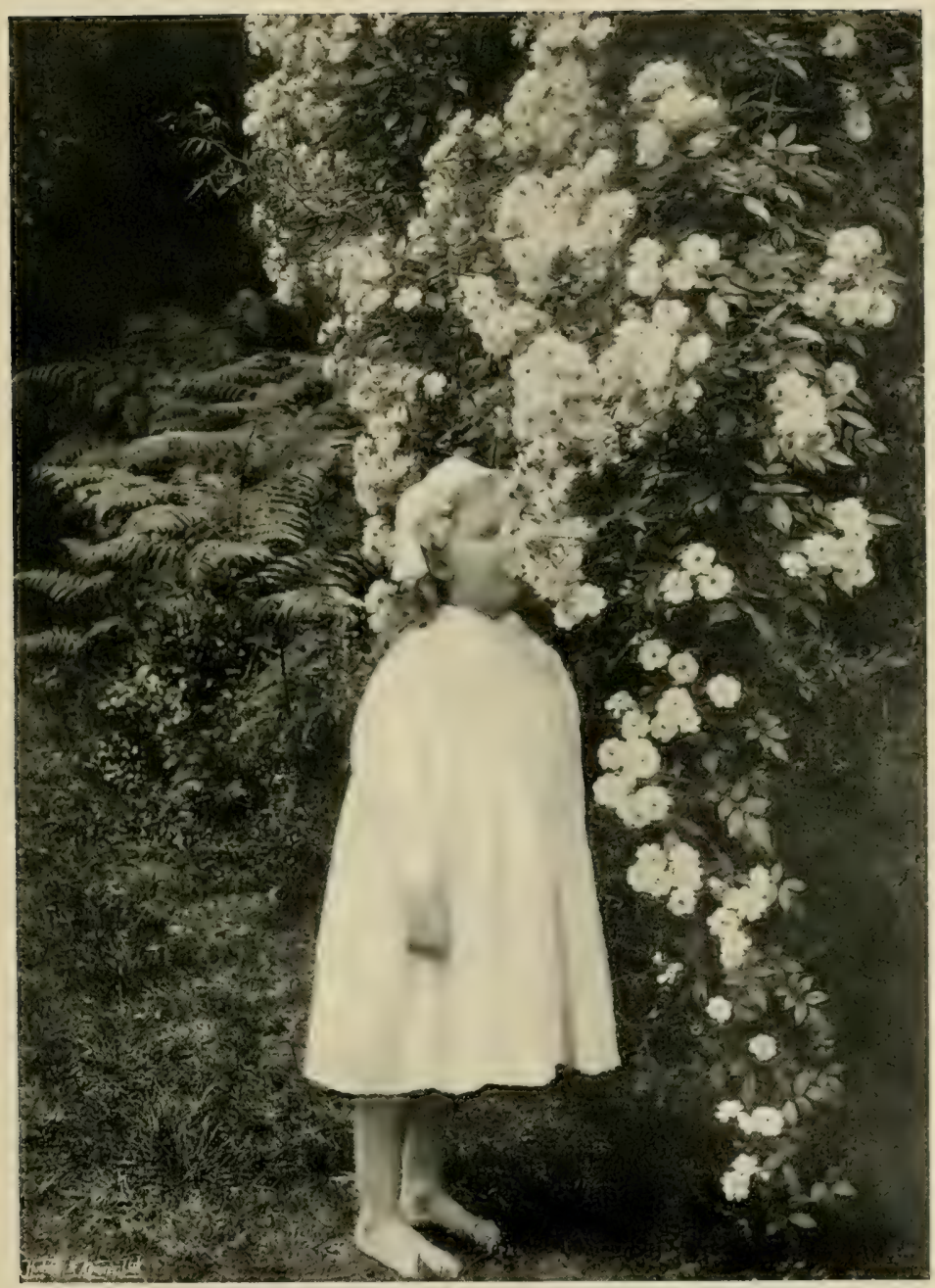

THE GARLAND ROSE. 


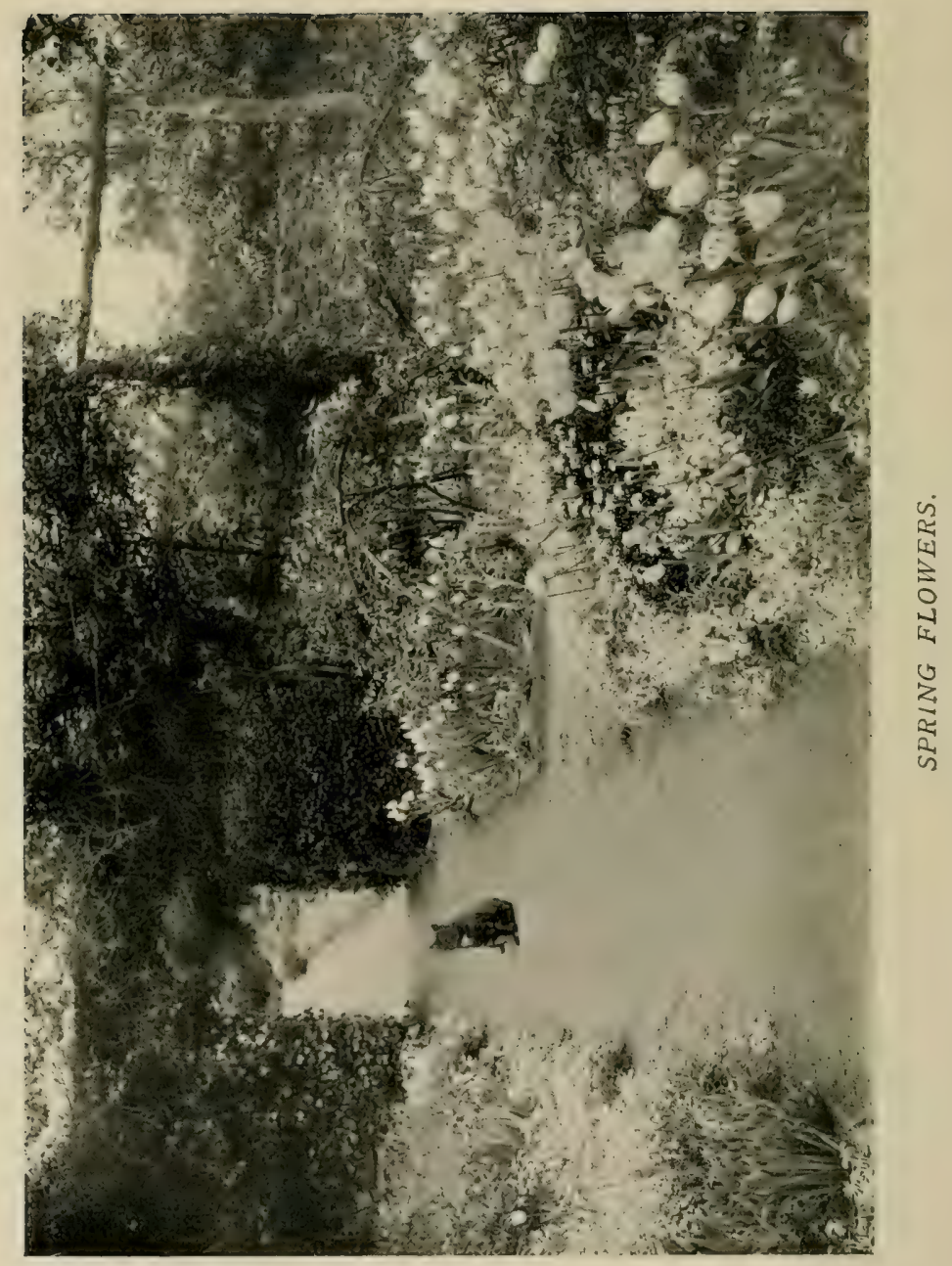


Swan (white), and Cottage Maid (pink). The Aubrietia, Cerastium, and Forget-me-not are the plants that could be taken away to make room for the later things. There should be a plant of Iberis, not taken up, for, though it flowers only in spring, the fine dark foliage looks well with other plants all the year; and there must be Columbines (the large white is the best), because they are such lovely and amusing flowers, with their flights of little doves sitting all round facing each other.

There must be some tufts of white Pinks, or better still, a part of the garden might be edged with it, and part with London Pride. Here is a picture of one end of my own spring garden, but you cannot have yours quite so full of flowers in April and May, because mine is in a corner that is given entirely to spring flowers, and $I$ do not expect it to be anything but a spring garden.

You should have, if possible, a plant or two of Phlox divaricata, with its masses of pretty pale bluish-lilac bloom, and one or two of the little Irises that flower in May; the prettiest is the Crimean Iris (Iris pumila coevulea). If your garden has a cool corner it should have Musk, and a plant of Foam-flower (Tiarella).

Perennial Lupines are biggish things, and so are the Flag Irises and the old garden Peonies; but if there is space there should be a tuft of each. Then for June there should be a clump of orange Lilies and one or two white Foxgloves, and again in the cool place the beautiful blue Cranesbill (Geranium ibericum platyphyllum). 
Among Roses you should certainly have the pompon Rose called Mignonette, the sweetest little neat bush with pale-pink flowers, and a China Rose, and one each of Damask and Cabbage Roses. I am afraid you will not have room for more; but if there is an arbour or any sort of hedge or fence that you can grow Roses over, you could have one or two of the rambling kinds; and if your garden should be next to a Holly or any tall-growing shrub, you could have any of these, or, best of all, a Garland Rose, and let it run up the tree and partly tumble out, so that some of its charming bloom is within nose reach. Rose arches are always pretty, but whether they will be desirable will depend on the shape of your garden, and how you approach it.

You must, of course, have some Snapdragons, begged from the gardener, who will have sown them early in March, and pricked them off in April into boxes or frames. You should learn how to do this, and when you get handy I daresay the gardener will be glad of your help. You must also ask him for some Canterbury Bells in October or November, for they are some of the very best plants in July. And you should have one tuft of the pretty white Bellflower Campanula persicifolia.

From July till the autumn the brightness of your little garden will depend a good deal on the half-hardy annuals and other bedding things, that were planted out in the first days of June, to follow the spring plants that were taken up, and to fill all bare places.

There should be, if possible, one or two plants of the short-growing Michaelmas Daisies; the prettiest 


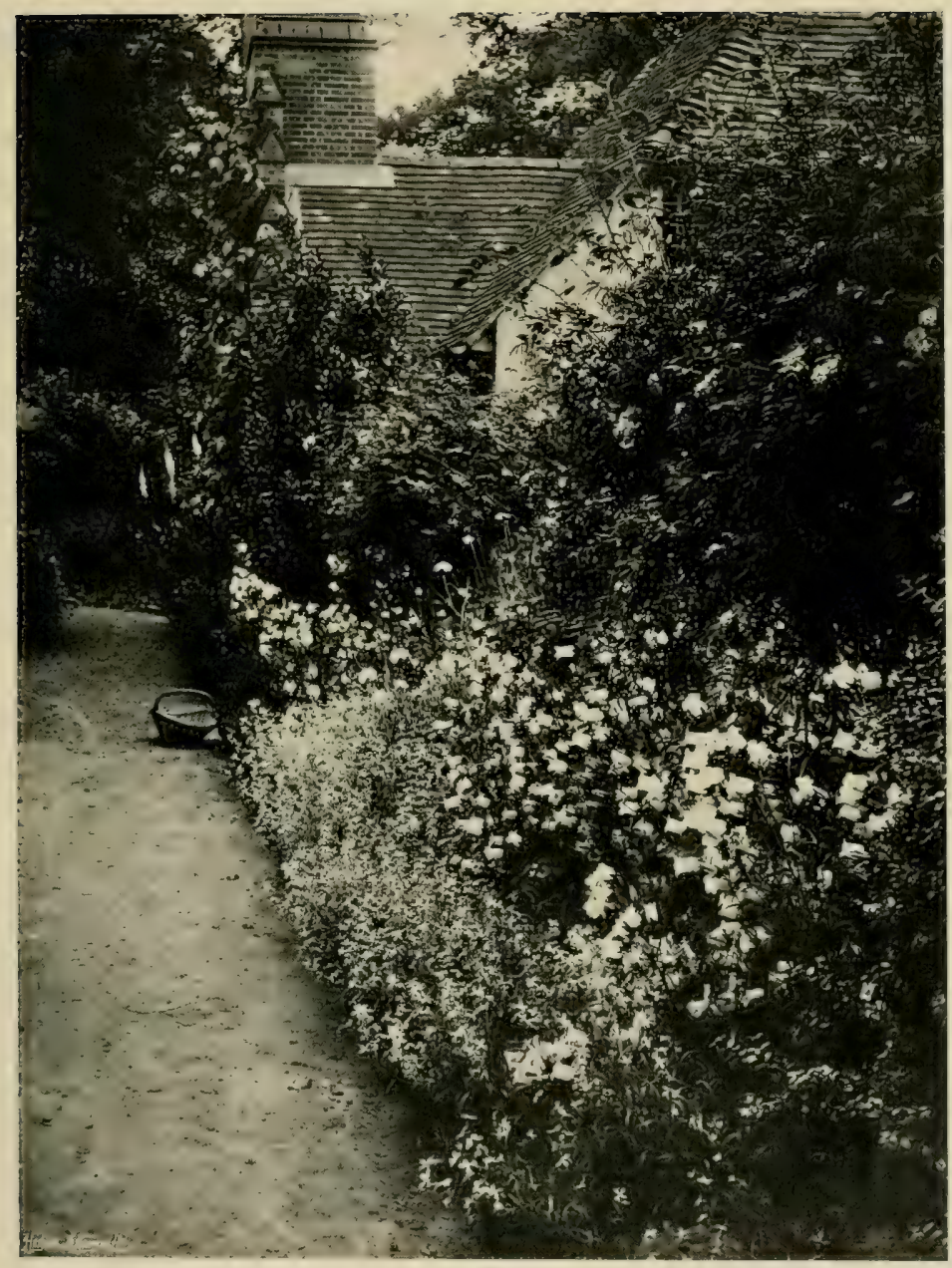

CANTERBUHY BELLS 


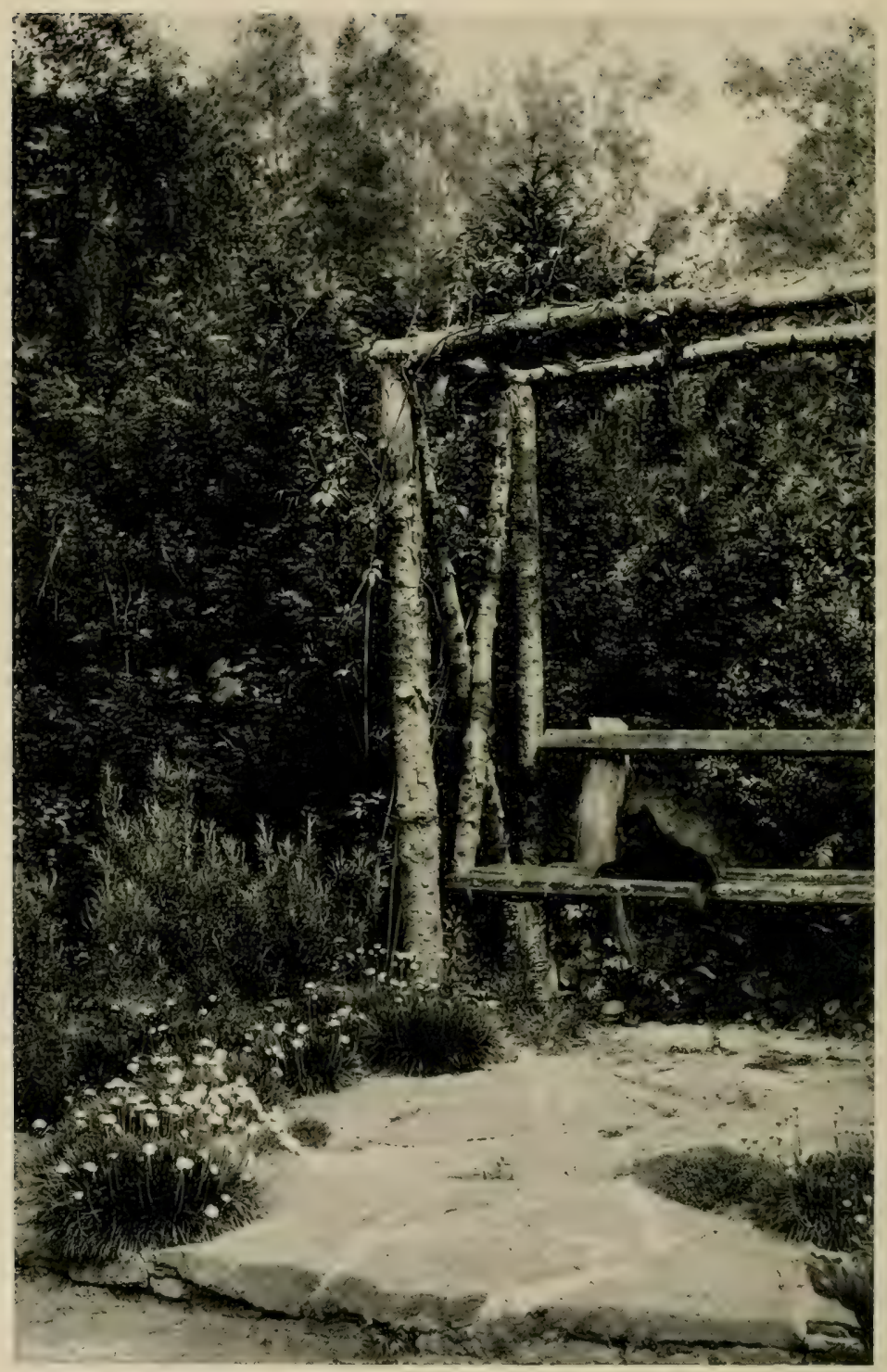

THRIFT IN A ROUGH STONE PAVEMENT. 


\section{FLOWERS FOR YOUR OWN GARDENS}

are called acris and Amellus. I am afraid you will have no room for the big grand plants of late summer and autumn, the Delphiniums, Dahlias, Hollyhocks, Tritomas, and so on. But you will enjoy these and be learning how to use them in the bigger home garden.

You may not even have room for all the plants I have named; if not you must choose from them the ones you like best. You should, if possible, have a little hedge of Sweet-Peas-sown early in March they flower in July, and remember, with these especially, but also with all other flowers, that if you want them to go on blooming you must cut off the faded flowers before they grow into big seed-pods.

If there should be any places where you can sow seeds of annuals in March, I think the nicest are Mignonette, blue Nemophila and Phacelia (two beautiful blues), pink Hawkweed, Love-in-a-Mist, double rose Godetia and dwarf Nasturtiums.

If you have any rough stone steps or a bit of paving in front of a seat or anywhere, remember how pretty it is to have some little plant like the small Bellflower Campanula pusilla running along under the steps, or Arenaria balearica growing all over their upright fronts, if these are in shade; or how nice it is to have some pretty little thing here and there in the joints of the paving. You see Thrift growing like this in the picture-do you see Blackie on the seat?-and there is a charming little tiny thing, an annual, called Ionopsidium acaule that should be sown in the joints of the stones early in September to flower next year, and that will ever after sow itself again. 
All the year you must be looking out for weeds and must see that you pull them up before they flower or seed. Nothing in gardening is more true than the old saying, "One year's seeding makes seven years' weeding"; and you must be watching to see if a plant wants a stick. Canterbury Bells and Columbines are sure to want sticks. When you tie a plant to a stick it is safest to give the raffia a whole turn round the

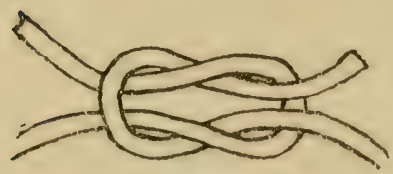

REEF-KNOT.

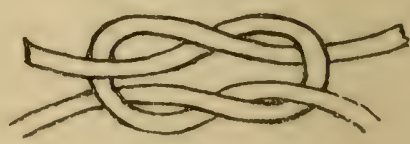

GRANNY.

stick before passing it round the stem of the plant, then it does not slip; and mind you tie a proper knot, not what sailors call a "granny." The right knot holds tight, but the granny has a nasty twist in it that easily pulls into a treacherous slip-knot, or pulls out at one end. I have drawn the knots before they are pulled up to show more clearly how they go. You should practise these knots, so as to be sure to get it right. The proper knot is called a reef-knot, because it is the knot always used by sailors in reefing, or tying up sails. 


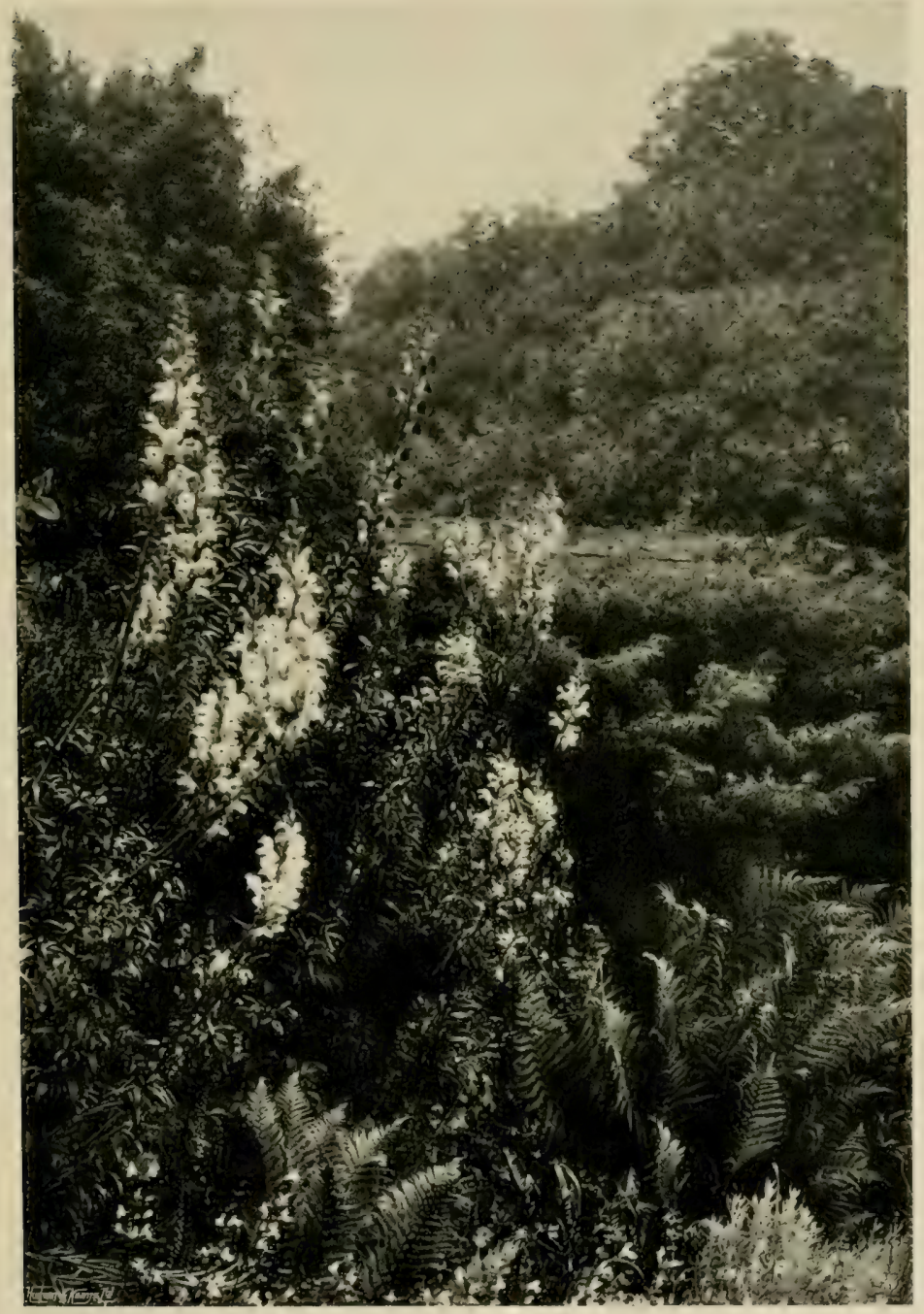

SNAPDRAGONS. 


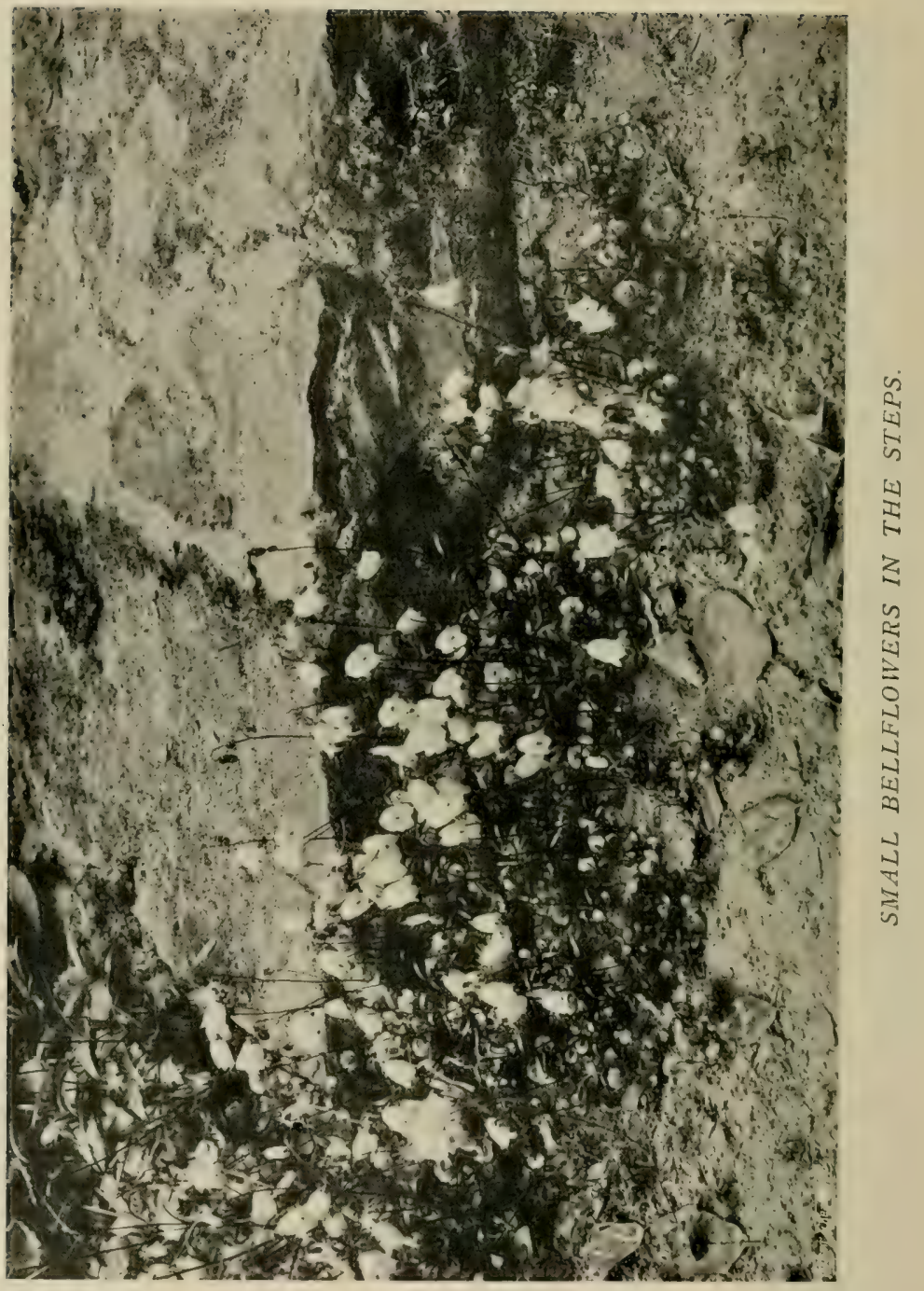




\section{CHAPTER X}

\section{ADVENTURES ON THE LAWN}

PERHAPS you will say that the lawn is not the sort of place where you expect to meet with adventures. Well, perhaps it is not, and yet such odd and unexpected things happen on it, things that are so deliciously thrilling, that I think I am hardly using too strong a word when I say " adventures." This summer it is hedgehogs. They are such interesting, mysterious creatures. I do not know how many there are about, but hardly a day passes without my seeing or hearing one. Of course they are easy to see when they come out on the lawn, and when I say "hearing one" I don't mean that it squeaks or grunts or makes any vocal sound, but that I hear the harsh noise of its bristles as it pushes through the low-lying branches of the shrubs at the edge of the grass.

The first one I met this year was on the narrow bit of lawn between the house and the wood. $\mathrm{He}$ was close to the Scotch Brier hedge that runs right and left of the steps that go up from the path on the south side of the house to the grass. Last year there was only one of his kind that we knew of; he used to 
come into the back-yard when it was getting dark and drink up what was left of the milk in the pussies' saucers. I thought perhaps this one would like some milk, but I am afraid I had begun to make his acquaintance badly by touching him with the tip of a stick instead of making him some complimentary speeches, for he had rolled himself up into a tight, prickly ball, and was very huffy. I left him for half an hour to see if he would recover his temper, and when I came back to do his photograph he was half unrolled. I thought this looked promising, so I got him a saucer of milk and then photographed him. But it was no good, for an hour later I went to the place and found Piggy gone and the milk untouched. Tavy came round just then and lapped it up.

But there is another one that comes to the part of the lawn where it is bigger and wider. He is much tamer, and seems to like to be talked to. The natural history books say that the hedgehog is an animal of nocturnal habits, meaning that it lies quiet and hidden in the day-time and wanders about and hunts for food at night. But this one lies out for hours in the sun on the lawn and seems to enjoy it. After I had photographed him he kept so still for quite a long time that I really began to think he must be dead, for though I looked quite close I could not see the slightest movement of the soft fur under the bristles that I thought I should see move as he breathed. I waited, watching quite quietly. Presently a blue-bottle fly came and settled on his snout; still he did not move. But the blue-bottle, fussing about his face got on to the edge 


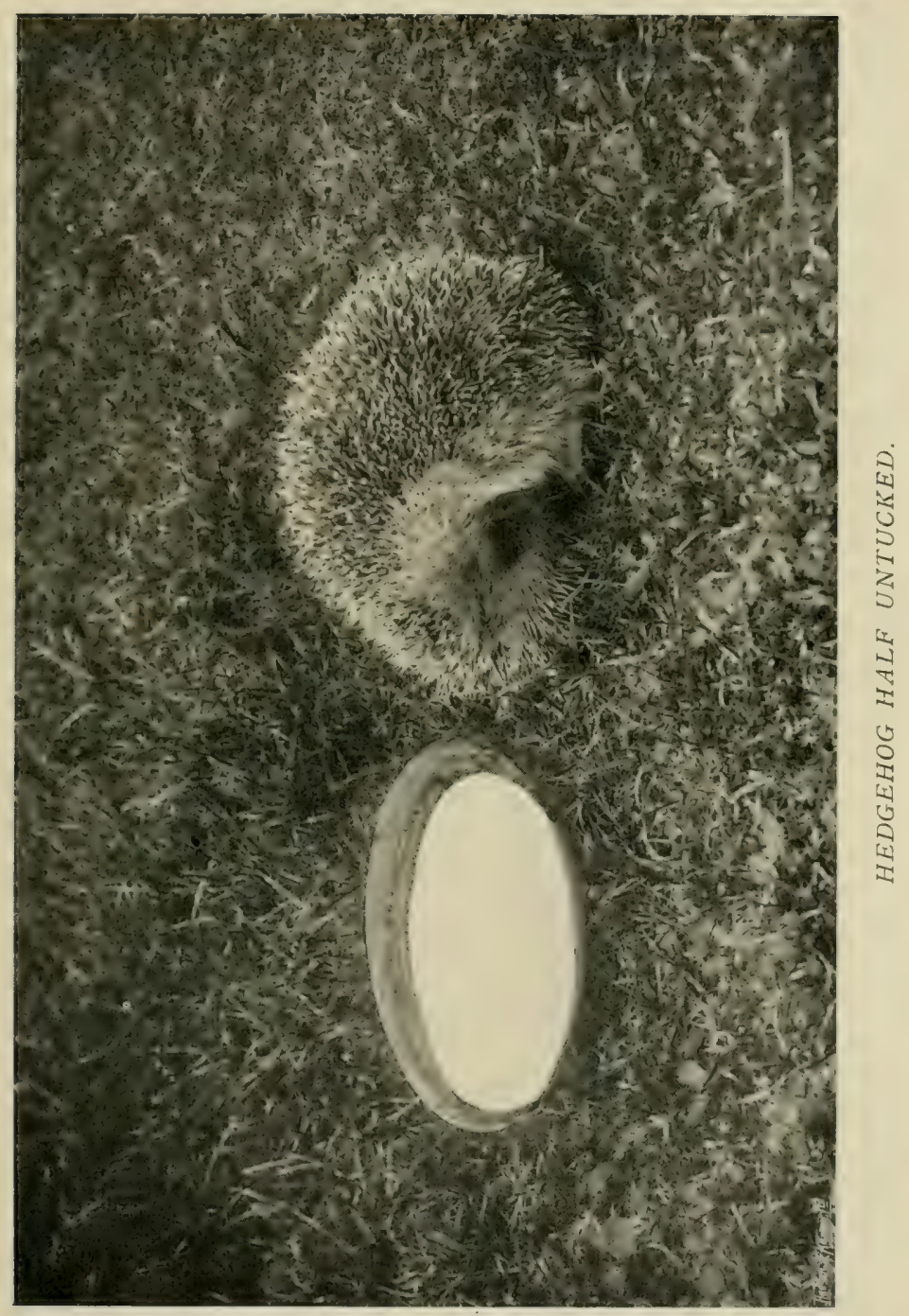




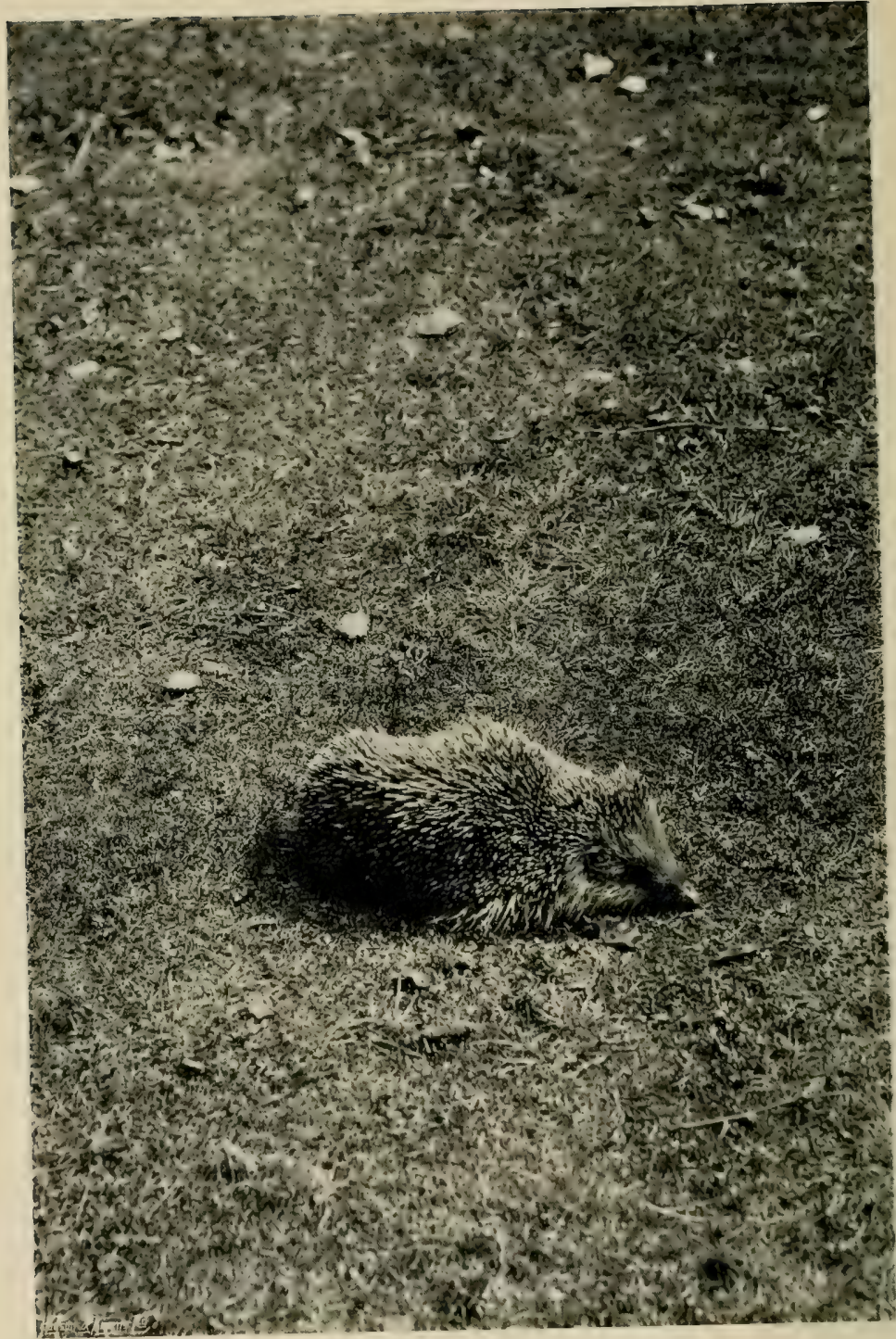

HEDGEHOG ON TIIE LAWN. 
of one of his eyes, and then he seemed to wake up, for he jerked his head suddenly to one side. I was quite relieved, and went to the kitchen and got the cook to give me a little sliver of raw meat off an uncooked leg of mutton, and stuck it on the end of a thin stick with a sharp point and took it to him. Cautiously I approached him and slowly brought the meat close to his nose. He sniffed it, and then at once took it in his mouth and chumped it up, and seemed to enjoy it immensely. It really was quite an adventure.

Once the gardener came running to me, much excited, and said-" There's a tortoise-shell on the lawn." I thought he meant a strange tortoise-shell cat, but went to see what it was, and, behold, there was a big tortoise! How it got there I cannot think, for there are only three houses within a near walk, and none of their owners had had tortoises. It has always remained an unexplained mystery. But I like mysteries, and hope you do too.

One day I had just come off the lawn on to the narrow terrace just above it against the west side of the house. I wanted to enjoy a good look at the lovely blue Convolvulus called "Heavenly Blue." It was climbing over the lower part of a vine. Moving some of the vine leaves with my hand I saw something dark against the stone wall. Looking closer I saw it was a bat. There he was, fast asleep, hanging up, as bats always do, by his hind feet, that were tight into a crack between the stones. One of his wings was partly unfolded, and the little claw at the end was also clinging to the stone. I thought it too good a chance 
to be lost, so I ran and got the camera and then tied back some of the vine branches to get a clear view of him. I was half afraid he would wake up and be off, but he never stirred. Their way is to sleep in the daytime and to fly about in the evening, as soon as it is nearly dark.

Perhaps my lawn in itself is more interesting than lawns in general. The soil is sandy with a very little peat, and the fine grasses and little flowers that grow in it are the grasses and flowers of the wild heath-land that I have always loved. A good deal of actual heath grows among the grass, and quantities of the sweet Wild Thyme and the pretty little Mouse-ear Hawkweed and white Bedstraw, and the small Milkwort. Nearly always where this pretty little plant grows it bears flowers of three colours; each colour on a different plant. So it does here, for in one patch the flowers are light blue, in another pink, and in another white. I love the lawn just before it has to be mowed, for when this is done the cruel machine cuts off all the sweet little flowers; the only patch of Thyme that escapes grows just at the top of some steps, out of the way of the machine.

This year there was a new lawn incident-a patch of the curious Dodder. It looks like a sort of badlymade pink cobweb of no particular pattern ; just pink threads crossing and tangling, and odd little stiff, tight, waxy flowers without stalks-nothing else-no leaves, only pinkish threads and flowers. It is one of those curious plants called parasites that do not grow honestly in the ground, but, like vegetable vampires, suck the 


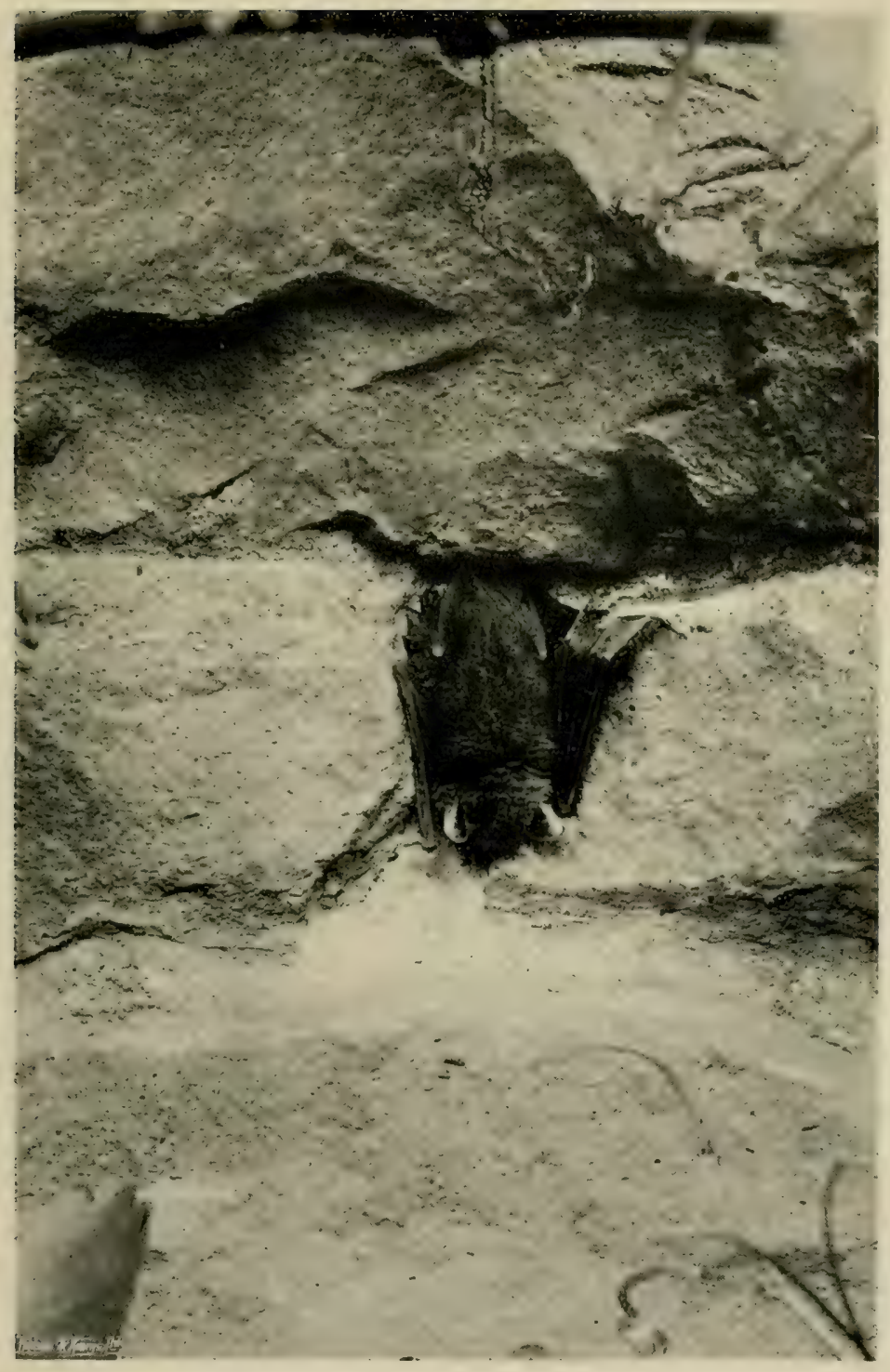

THE BAT. 


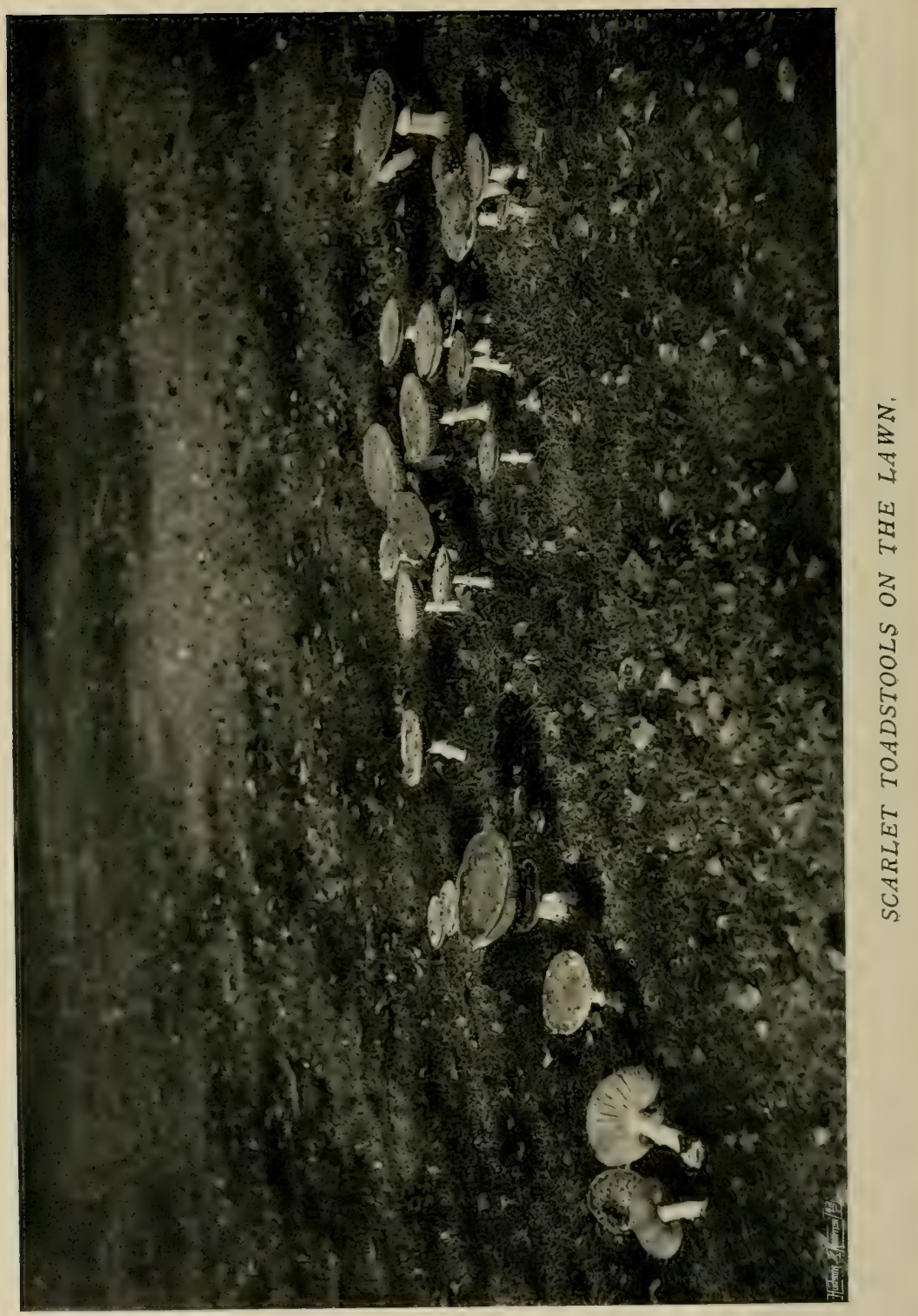


blood of other plants. Dodder generally grows on Clover or Heath. Of course it is very bad for the unfortunate plant it grows on, but, all the same, as it is not a very common thing, and is so very curious, I like to see it on the lawn.

After rainy weather in August there are always a few real Mushrooms, and later, among a number of other funguses, a handsome show of the great red Toadstools that always come where there are Birch-trees. Their proper name is Fly Agaric. They are a brilliant scarlet-red on top, with little white knobs; the gills underneath are white. They are very poisonous. Close to them grow other funguses, some of them eatable, the Parasol Mushroom being very good indeed, but I won't describe this, because it is rather like some other kinds that are dangerous. But there is one capital fungus that you cannot mistake if you attend carefully to what I describe. This is the Chantarelle. It does not grow in the lawn or even in open grassy places, but there are some in the wood close by, and I had better tell you about it. It generally grows under Oaks in cool, rather hollow places, where leaf-mould has accumulated. You will see

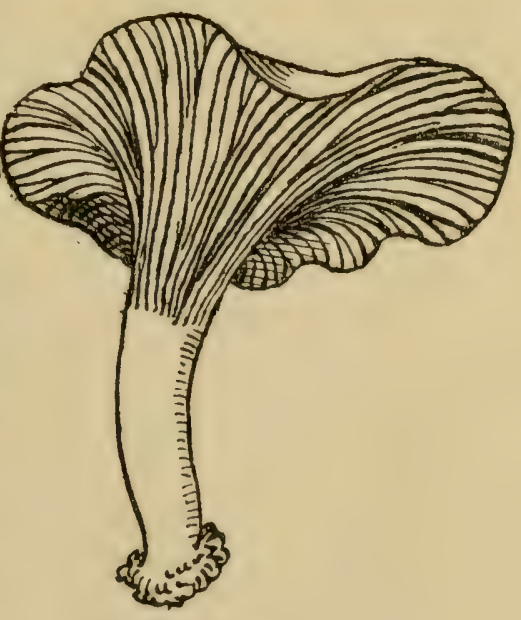

CHANTARELLE. what it looks like by the picture, and it has just the 
colour and the smell of a ripe apricot. The picture makes it look a little harder than it really is, for the texture of the gills is almost buttery. It shows one of medium size, but they are often larger, and when they are of the larger sizes the edges are more waved and stand more upright, like an umbrella blown inside out. If there is good rain towards the end of August it wakes up the Chantarelles and makes them grow, and they generally go on till about the middle of September. They are nice plain broiled, like Mushrooms, or stewed in stock and finished with a little cream. I always delight in them, not only because they are very good to eat, but because the looking for them takes one into such pretty woody places.

I must tell you about my owl. When my house was built eleven years ago I had a little opening left

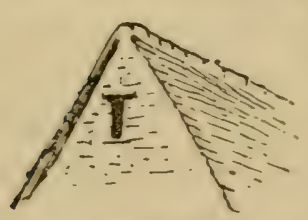

THE OWL'S HOUSE.

in one of the end gables. You know the ceilings of bedrooms do not go right up to the top of the roof. The ceiling is flat and the roof pitches up both ways to the top line, which is called the ridge, so that there is a triangular space inside between the ridge and the woodwork that supports the ceiling. Owls are fond of getting into places of this sort, but though I hoped an owl would come I didn't want to have him flopping about all over inside the roof, and perhaps hooting or screaming just over our beds at night, and frightening us out of our wits; so just inside the opening I had a wooden enclosure made so that he would have a nice little room to himself. Year after 


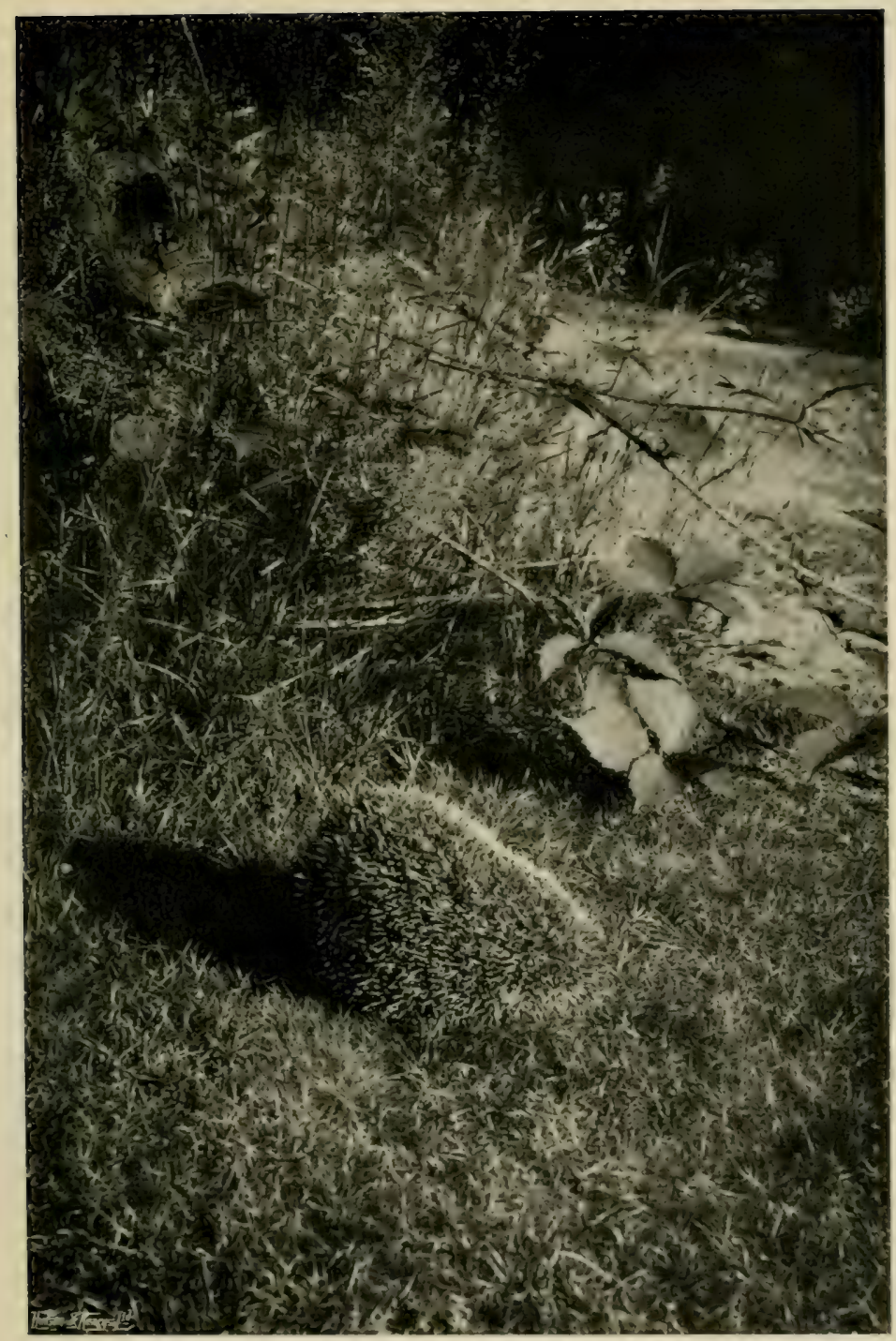

HEDGEHOG OUT FOR AN EVENING PROH'L. 


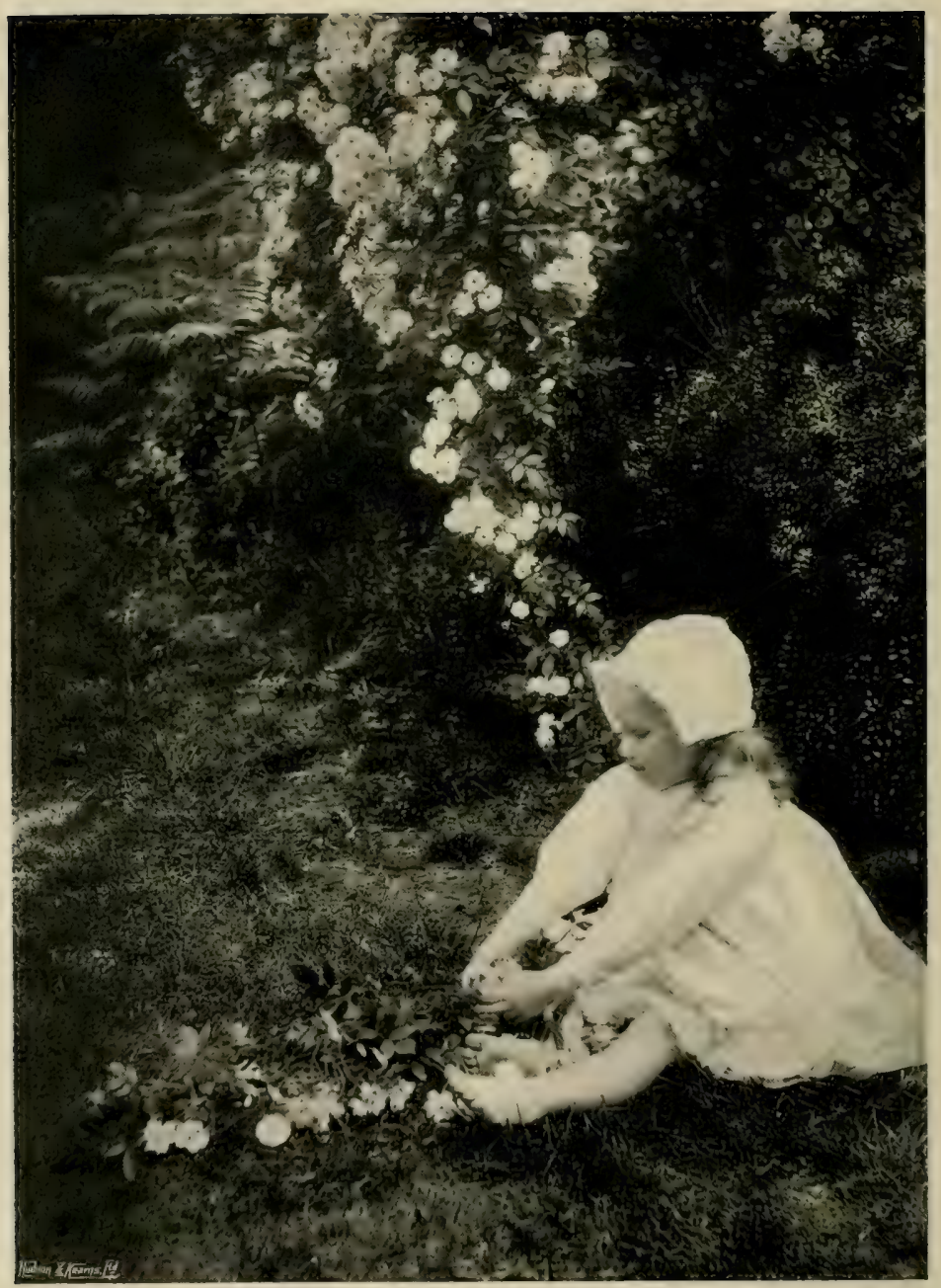

"IT'S A PRICKLY JOB." 
year passed but no owl came. But this spring I saw a dark roundish object lying on the paving just under the opening I had provided for his entrance. I seized upon it, for I thought it meant that an owl had come at last. I broke it up and found it was what I expected. It was an owl's pellet. They hunt in the late evening and catch and eat numbers of mice, and seem to swallow them whole. Their insides, after digesting the flesh of the mice, work up the fur and bones into long-shaped balls, which the owls throw up. How I should have liked to see my owl sitting at the door of his house disgorging his pellet! This is evidently what he does, for I have found a number of them in the same place. I have never yet actually seen him myself, but the gardener saw him one light summer night flying back to his door, no doubt with a mouse, and we often hear him round about the house at night. It is one of my adventures.

Another of my adventures is stalactites. It is an adventure in three chapters.

Chapter I.-As children we used to have an old book with pictures about all sorts of wonderful natural things, icebergs and Niagaras and whirlpools and volcanoes, and the immense caves and subterranean lakes that are found in the hearts of some mountains. It was called Wonders of Creation, or something like that. I used to look at the pictures with a sort of dreadful pleasure, but I think nothing delighted my excited imagination so much as the picture of some vast cave where there were stalactites, the curious great stone icicles that form where water impregnated with 
lime drips slowly, and where corresponding ones called stalagmites rise up from the floor of the cave to meet them.

Chapter II.-When I built my barn and stable, there was a place made at one end that I thought would do to grow Mushrooms in. It has never been used for that purpose, though it is very useful in other ways, but it is always called the Mushroom-house. It is partly underground, the walls are thick and of solid stone, and the top is solid stone too, built barrel-shaped. It is made so because I wanted to have a large openair tank over it that would collect the rain-water from the barn. This was done, and the floor of the tank over the Mushroom-house was cemented. But when the tank is full there is an immense weight of water pressing upon the roof of the Mushroom-house, and just a very little water seems to be squeezed through the cement and stone. It does not come into the lower place, but makes a very slow drip just at the rough stone arch over the door.

Chapter III.-Little stalactites are forming, to my great delight! Look at the picture and you will see them! 


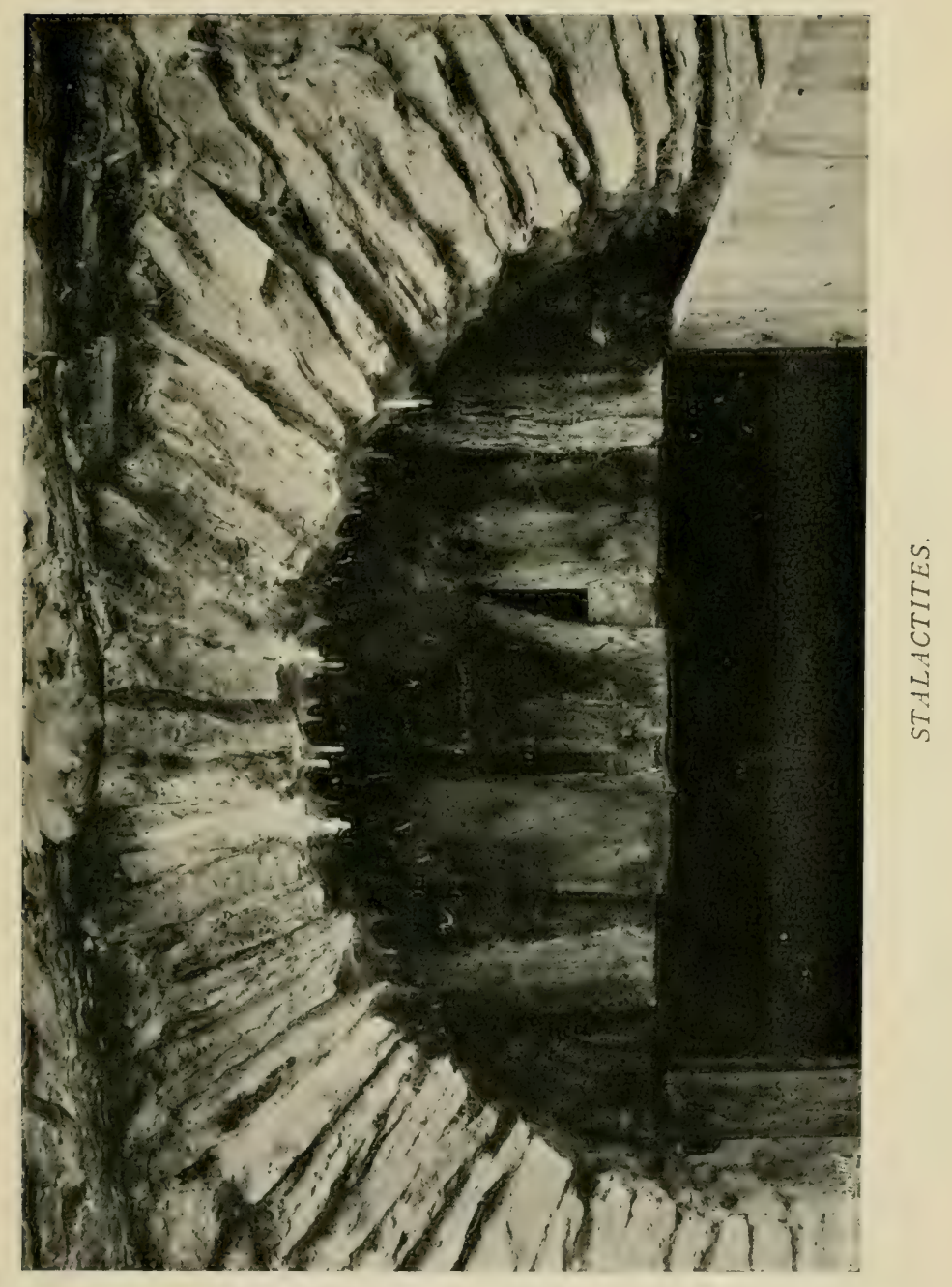




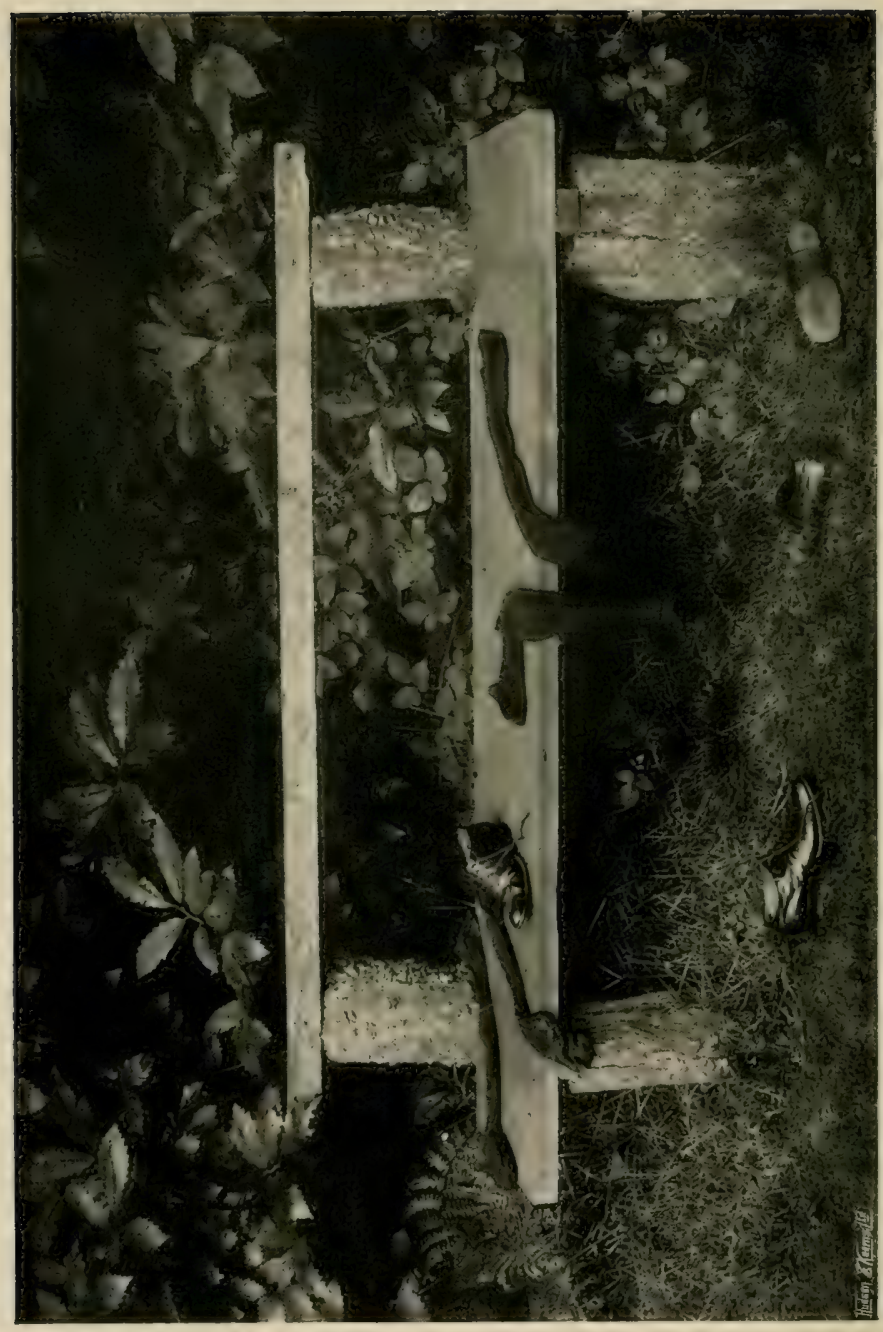

告 


\section{CHAPTER XI}

\section{VARIOUS AMUSEMENTS}

THERE can be no doubt that the proper place for our shoes and stockings is on or near a garden bench, where we kicked and grabbed them off, as the picture shows, even if we so far conformed to the ways of civilisation as to put them on at all. In fact they are generally left indoors. How happy we are nowadays, that we can be allowed the comfort of going barefoot. Do you know, when I was a child we did not even paddle when we were at the sea-side; that delight had not been invented. We went to bathe in a horrible bathing-machine; there was not even such a thing as a bathing-tent or hut by the shore. It is true we had wooden spades, and made moated castles, when the incoming tide first filled the moat and then melted the castle, but it was all done in shoes and stockings. But in many places we can do sand-games at home, for if there should happen to be somewhere just on the edge of the home garden that delightful thing a sand-pit, it is a place of everlasting joy when one is small, and even when one is growing fairly biggish. We dig out arched recesses to sit in, and we build castles and all sorts of 
houses with the heap of loose sand at the bottom. It is a great help to have a few common roofing tiles, or half tiles, because they are so useful for making the tops of doors and windows, and the sides too. And then we get some flowers and make quite a pretty garden round the house. Of course it is grand if our father happens to be an architect, and sometimes likes to play too, and shows us how to do buildings. A large round castle is a good thing to make, with thick walls carried up as high as we can get them, and one door in the bottom. Then we put some dry grass and leaves and sticks inside, with paper under, and light it at the door hole, and have quite a fine castle on fire.

But you will find out endless ways of playing with the sand-pit. Perhaps there will be some loose stones lying about for all sorts of play-building. The pit need not be so deep as the one in my picture, where Christopher is climbing up the dizzy heights, having deposited his small brother on a safe shelf at a lower level. Do you see the row of holes in the face of the pit rather high up-they are made by the sandmartins, pretty little birds of the swallow kind that migrate, as naturalists say, meaning that the bird is in England only a part of the year. They come in March or April and are gone early in September. They make neat round holes in the sand, boring deep into it, so that the nests are nearly two feet from the entrance hole. They are what is called gregarious, meaning that a number of them make their homes near together. In digging their holes they carefully choose just the kind of sand that suits them best. 


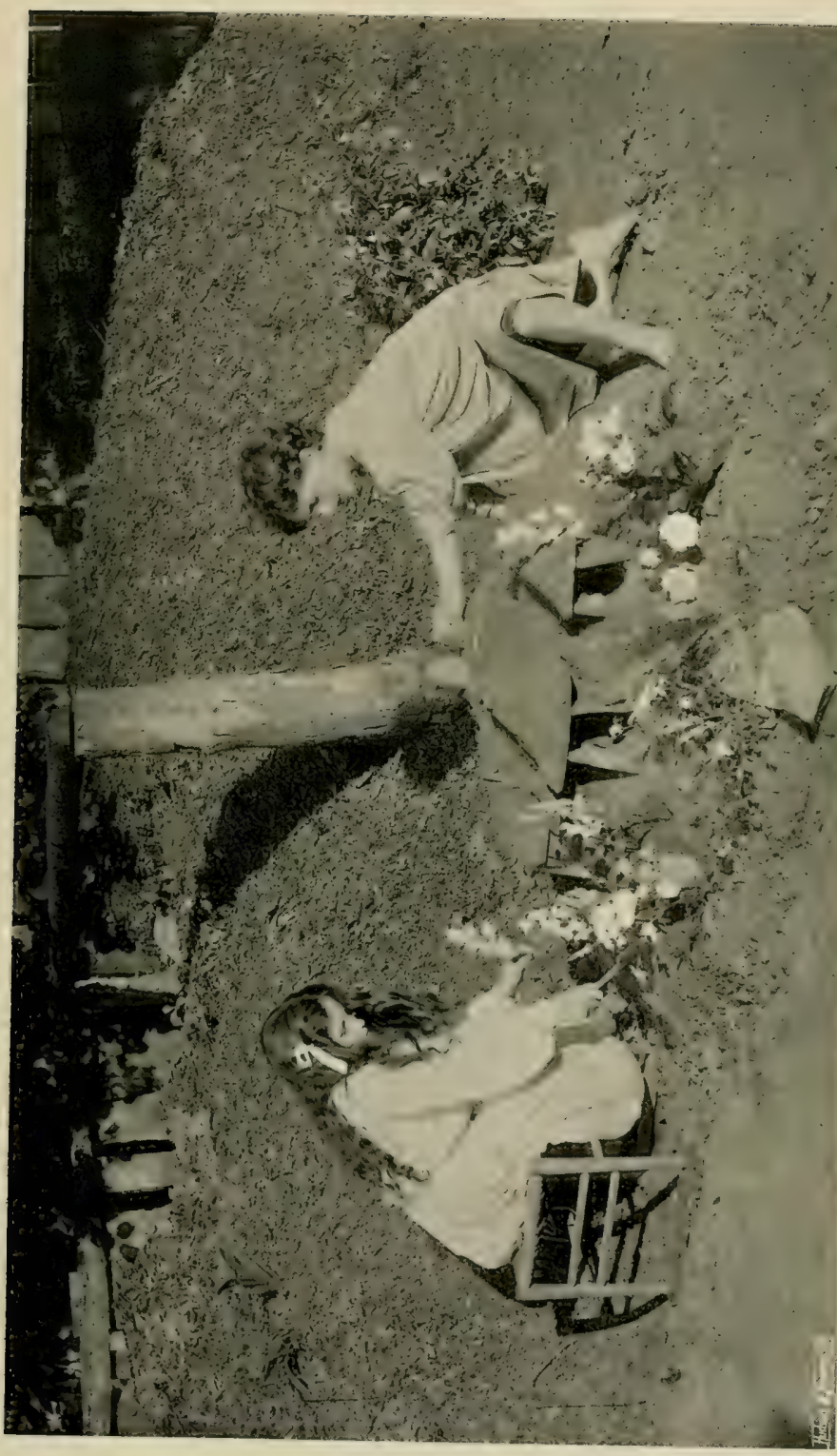

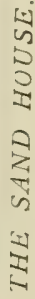




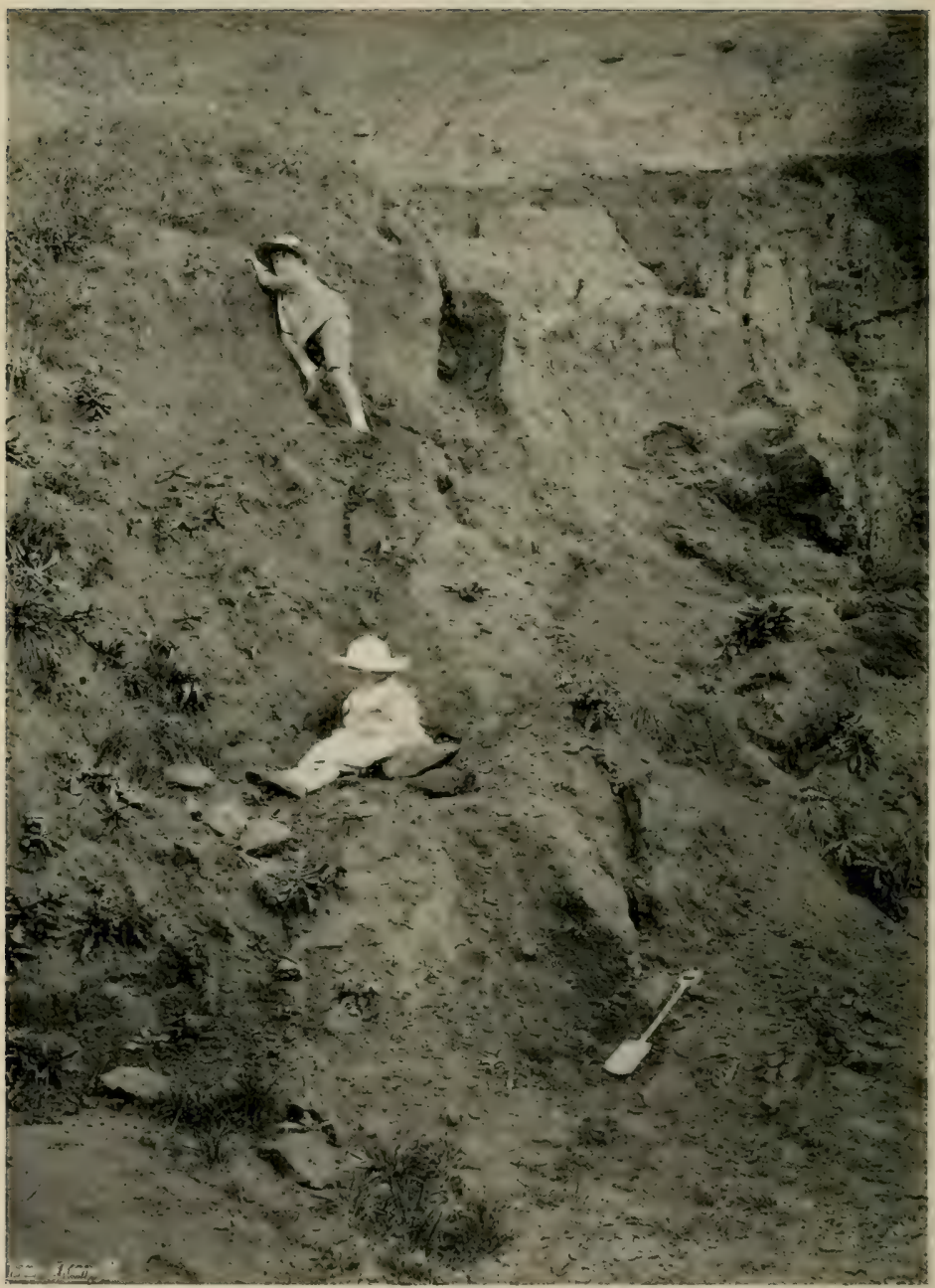

IN THE SAND PIT. 


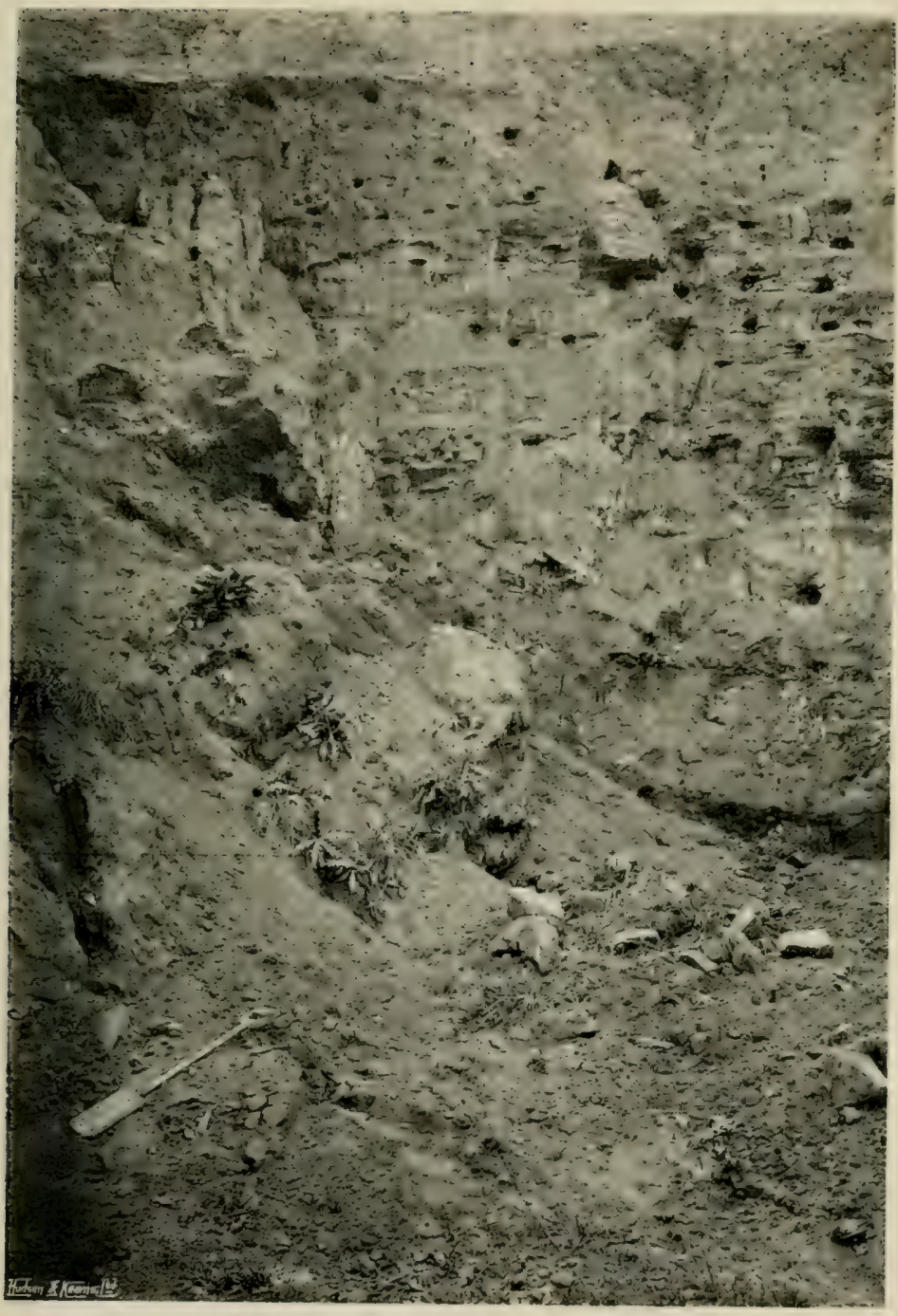

THE SAND PIT. 


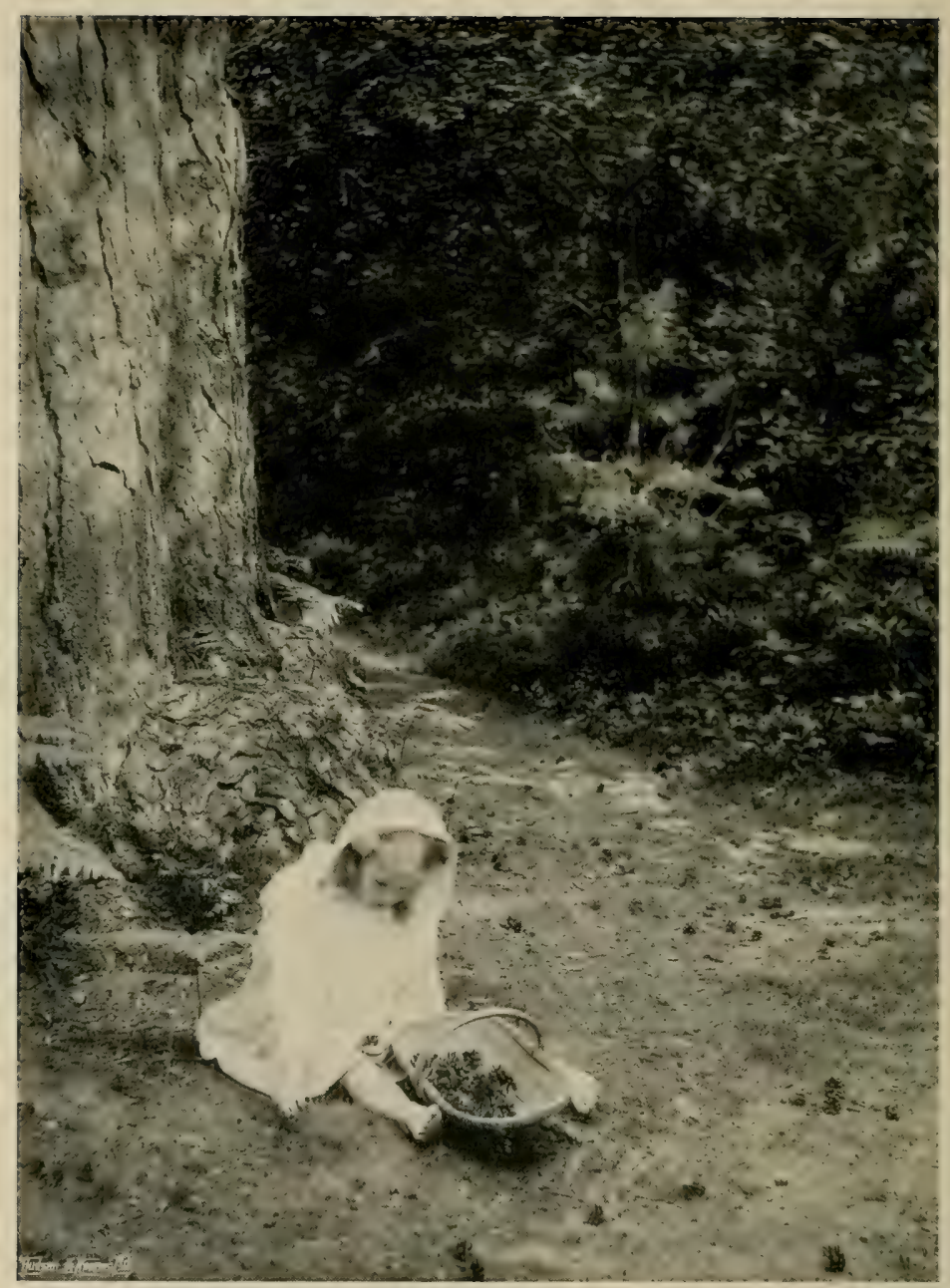

GATHERING FIR-CONES. 
You can tell this by seeing that the nest holes are always in rows. The sand lies in what geologists call strata. A geologist is a man who knows all about stones and how the earth is made. A stratum (which is really a Latin word adopted by the English language) means a layer. Nearly all our earth is in layers or strata of one kind or another. In a sand-pit or any quarry you can generally see the strata, because either they are different in colour, or the harder ones stick out a little because the softer get dislodged or washed out by wind and rain. So you see the sand-martin looks out for a stratum that just suits him for digging - not too hard for his tender little bill, and not so soft that it would crumble away. You see they like playing in the sand-pit too, only their play is in good earnest.

Where there are sandy places there are generally Fir-trees. We look out for the fallen cones. They are well worth collecting; they are such capital things to brighten up a dull fire in the nursery or schoolroom. Even the smallest of us who are big enough to do anything can collect fir-cones. Dorothea is only six, and does it capitally. There should be a big bag or box filled with them for the fire of the play-house parlour.

Then where there are sand and Fir-trees there is pretty sure to be Bracken Fern, and we make fernpegs for pegging down Verbenas and Phlox Drummondi, and for layering Carnations. The gardener is very glad to have them, and he does so much for us that it is nice to be able to do something really useful for him. It is not work for the younger but for the older children, because it has to be done with a sharp knife, 
also the Fern is best cut with a fag-hook, another sharp-edged thing. The pegs are best cut in August, when the Fern stems are firm and hard. You cut the whole fronds with the fag-hook and lay them all one way in some nice shady place near, carrying the cut fronds

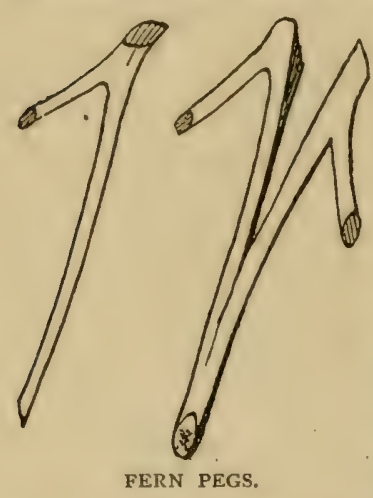
very carefully so as not to break them. You have some low seat to sit on, and put it at the stalk end of the ridge of cut Fern. Then you take a frond by the thick end and cut off the side branches an inch from the stem. Each stem makes two, sometimes three good pegs. Then you cut the stem so that each peg will be three and a half to four inches long. It is not much use leaving both crooks on the peg, but when the stem is big and strong the thickest one can have the stem sliced right down, making two pegs. The pegs can be used the same year, but it is much better if they are made one year to use the next; they dry up so nice and hard. Besides, if you use them the same year you have to cut them early in July, when the Fern is not so strong, because by the middle of July you want them for use. I never advise that the growing fronds should be cut with a knife, because you are so likely to get a cut finger, not from the knife but from the outer edge of the fern stem, which has a coating almost like glass. By using a fag-hook or reaping-hook your hand is well away from where the cut is made. 


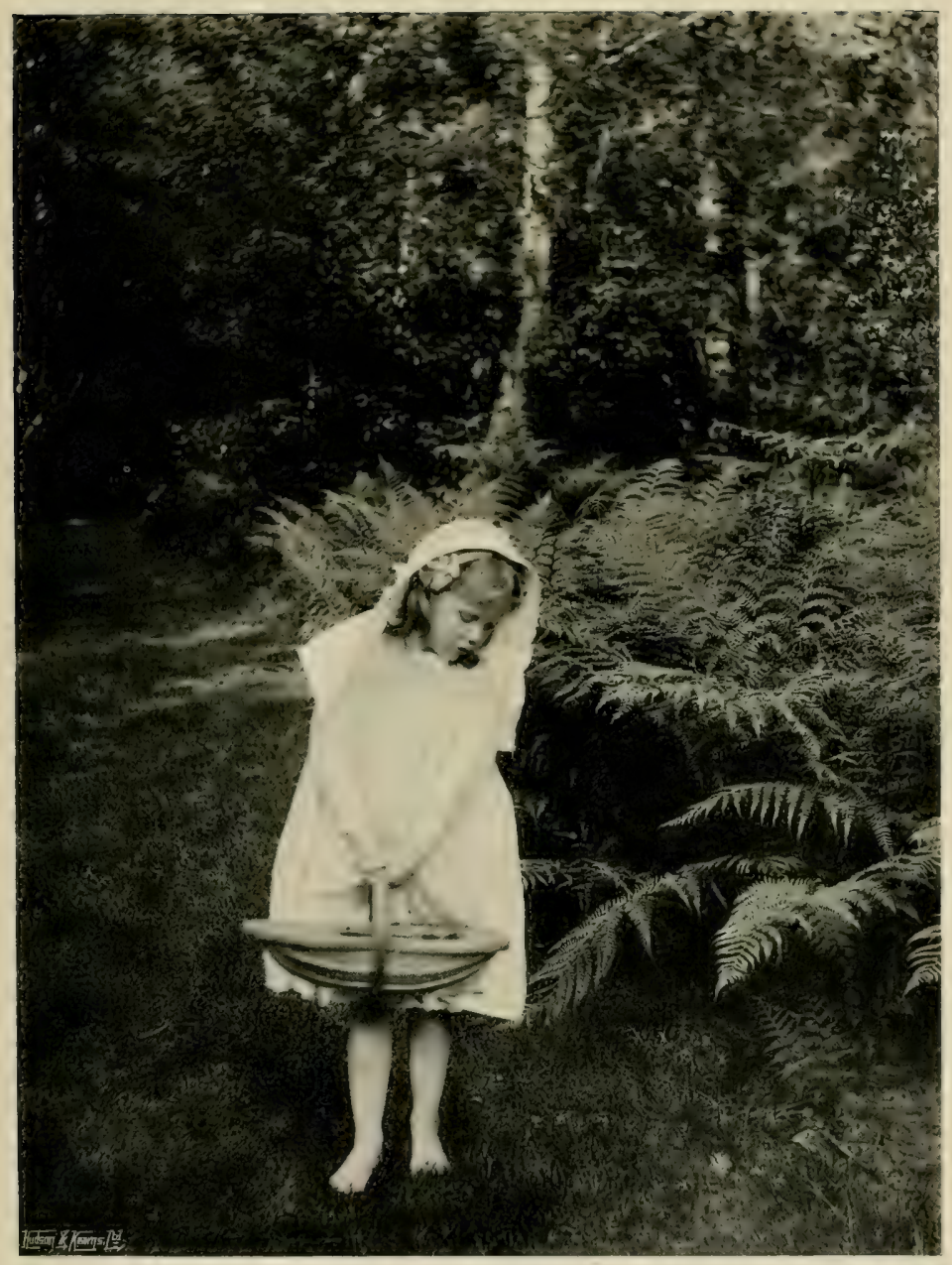

"THERE ARE TWO MORE CONES, I SUPPOSE I MUST PICK THEM UP." 


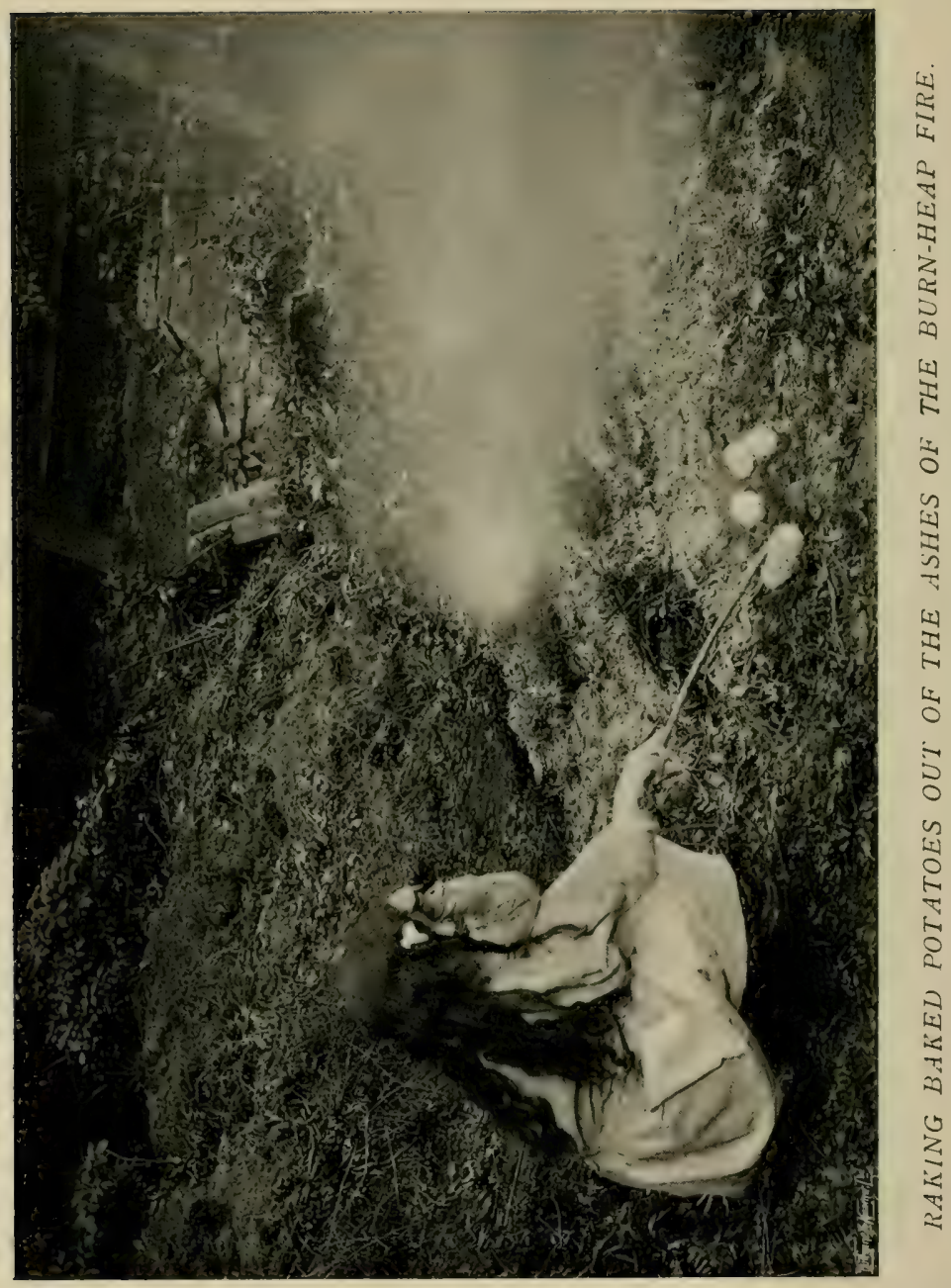


I had always great delight in watching and feeding the fire at the garden burn-heap. I have the same pleasure in it now that I am old. It is such a clean, tidy, satisfactory way of getting rid of all the cart-loads of rubbish that come out of a well-kept garden, and it makes such a nice excitement, and then there is such a good smell, and one has to be up to all sorts of dodges to keep out of the smoke. What a smoke it does make if there has been rain and a good deal of the stuff is rather wet, or if there are many green weeds to burn up. Then when it is all burnt, and the great heap of ashes is left, still with a smouldering heart of red fire inside, we beg some big potatoes and put them in at the bottom-not too far in or they would be burnt, but far enough for them to be nicely roasted in about three-quarters of an hour. We time it to suit a playhouse tea or supper, and they just are good with a little butter, pepper, and salt; and it is all the more amusing because our plates get rather messed with the remains of the burn-heap ashes that stick to their outsides.

While we are about fires, I want to tell you my way of making a picnic fire. In many places there is rough ground adjoining the some garden, where it is nice to take out the tea and boil the kettle and have a sort of home picnic, and of course the same way of making the fire applies to any more distant place. I never make a great sprawling untidy blaze, that perhaps in dry weather sets fire to the bushes near, and leaves a nasty great space of black and grey ashes. When I used to make picnic fires in all sorts of beautiful 
places all over the country, it was necessary to make them small and neat, for most of the places were on heath-land, where, if you are not careful, you may set fire to the whole place and do a great deal of damage. I always choose a place in uneven ground; if possible a bit of steep bank, which should face the direction of the wind.

You hold up a handkerchief to find out which way the wind is, or if the wind is very slight burn a bit of paper, when the smoke will show you the way it blows. Even if there is hardly any wind it is comfortable to have the smoke blow away from you; besides, it helps the draught of the fire.

I always took a spade and a pair of bellows, and made it a point of honour to have the kettle boiling within five minutes of lighting the fire. It is much better to take a bag of fuel than to depend on what you can pick up; I always had bits of deal about six inches long and anything from a quarter to threequarters of an inch thick. These go in the fuel-bag, with the box of matches and some bits of newspaper. My square, flat-shaped kettle I had made on purpose. The upper part is tinned iron and the bottom copper. The picture shows it ; it is nine inches long and seven wide; the sides are two inches high. Then I have two small iron bars, square in section, fourteen inches long by three-eighths of an inch thick. Having found out the way of the wind and chosen the bit of bank facing it, I cut a neat hole in the bank with the spade, the same width as the kettle, that is seven inches, and the other way two inches longer than the length of the 


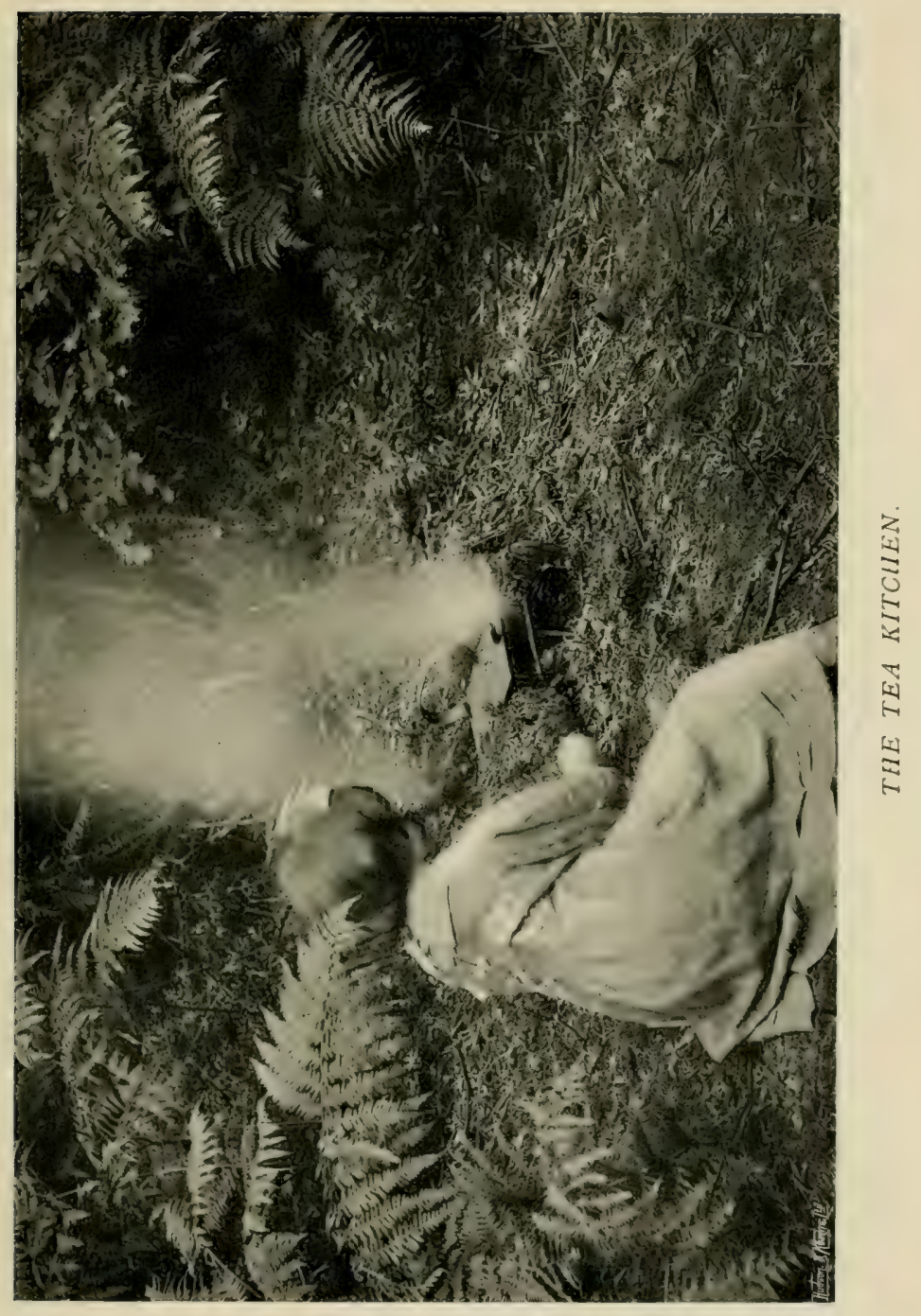




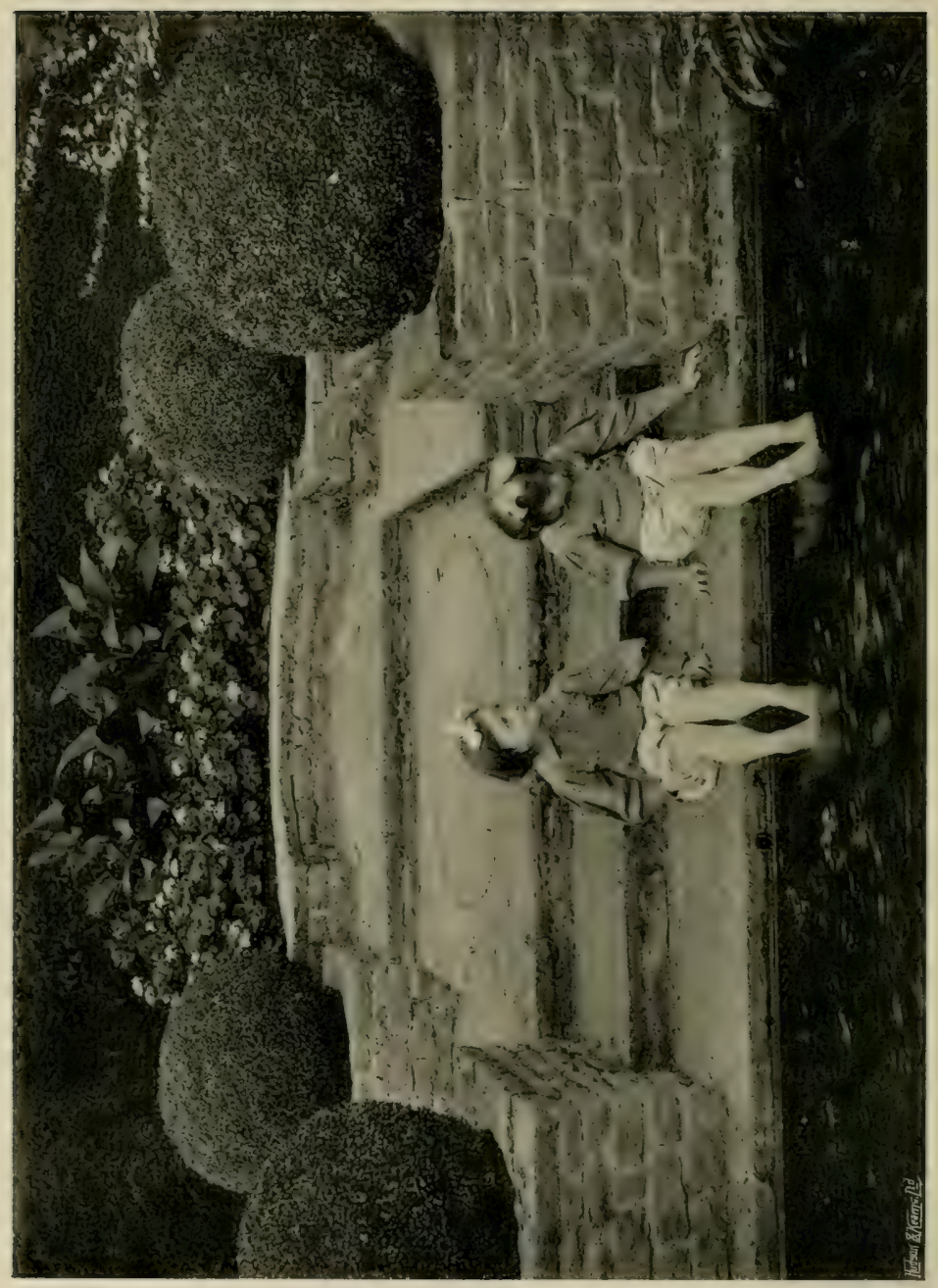

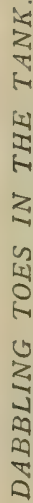


kettle. The kettle is nine inches long, so that makes eleven inches. It is more convenient to get at if the bottom of the fire-hole is a little way up the bank, as you see in the drawings, not quite down on the lowest ground-level. Then at the height where the kettle will sit, which is barely five inches from the bottom of the fire, I cut the bank nice and level on each side of

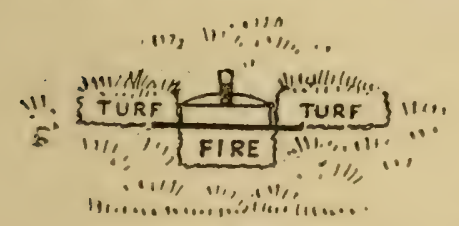

Front.

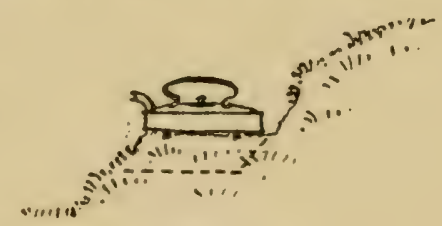

Side.

THE TEA-KITCHEN.

In the right-hand figure the bottom of the fire is shown by a dotted line, and the side turfs are omitted for the sake of clearness.

the fire-hole for about ten inches to right and left. On this level the irons are laid, about five inches apart, and the kettle is put on. You will find you have two inches between the back of the kettle and the bank. You must see that it is all nice and level, and that the kettle sits quite firm and comfortable. Now you take the spade again and look out where you can cut two good solid turfs, twelve inches long by ten wide and three inches thick. You lay them carefully, turf side up, over the ends of the irons by the side of the kettle. Unless the bank is quite steep it is as well to put another turf across the back of the fire-hole.

All this sounds much more elaborate than it really is. When you know what to do it takes barely three minutes, and if you will get a flat-bottomed kettle, and 
do it exactly as I have described, I don't think you will ever want to make a picnic fire any other way as long as you live.

When you have done with the fire you pour the spare water from the kettle on it, taking care that not a single live spark remains, you put back the turfs where they came from, and leave the place looking as much as possible as if it had never been disturbed. No débris or rubbish of any kind must be left lying about. Bits of paper go back into the picnic basket, and not even a chicken-bone must be left on the ground. You have the spade, and can bury everything, or you can bury things in the fireplace.

Sometimes I have built little tea-kitchens for permanent use, but with fire-bricks, in some favourite place in private ground near home, but they were always on the same pattern. Their only advantage is that you save a few minutes' time and need not take the spade, but then they are not always right for the wind.

Nothing is more delightful than any sort of playing with water. In places where there is no safe pool or stream we can get some fun out of a fountain basin or a garden tank; even if it is only sitting on the edge and dabbling our toes on hot summer days.

I used to invite Bar and Pam to what we called a tank-party (of only ourselves) whenever my stone-built tank, which is ten feet square and two feet deep, was nicely cleaned out and had had fresh water let in. A stout bit of plank floats in it, called the pussies' safetyplank, because, if a pussy slipped in and the water happened to be low, he could not get out, but he could 


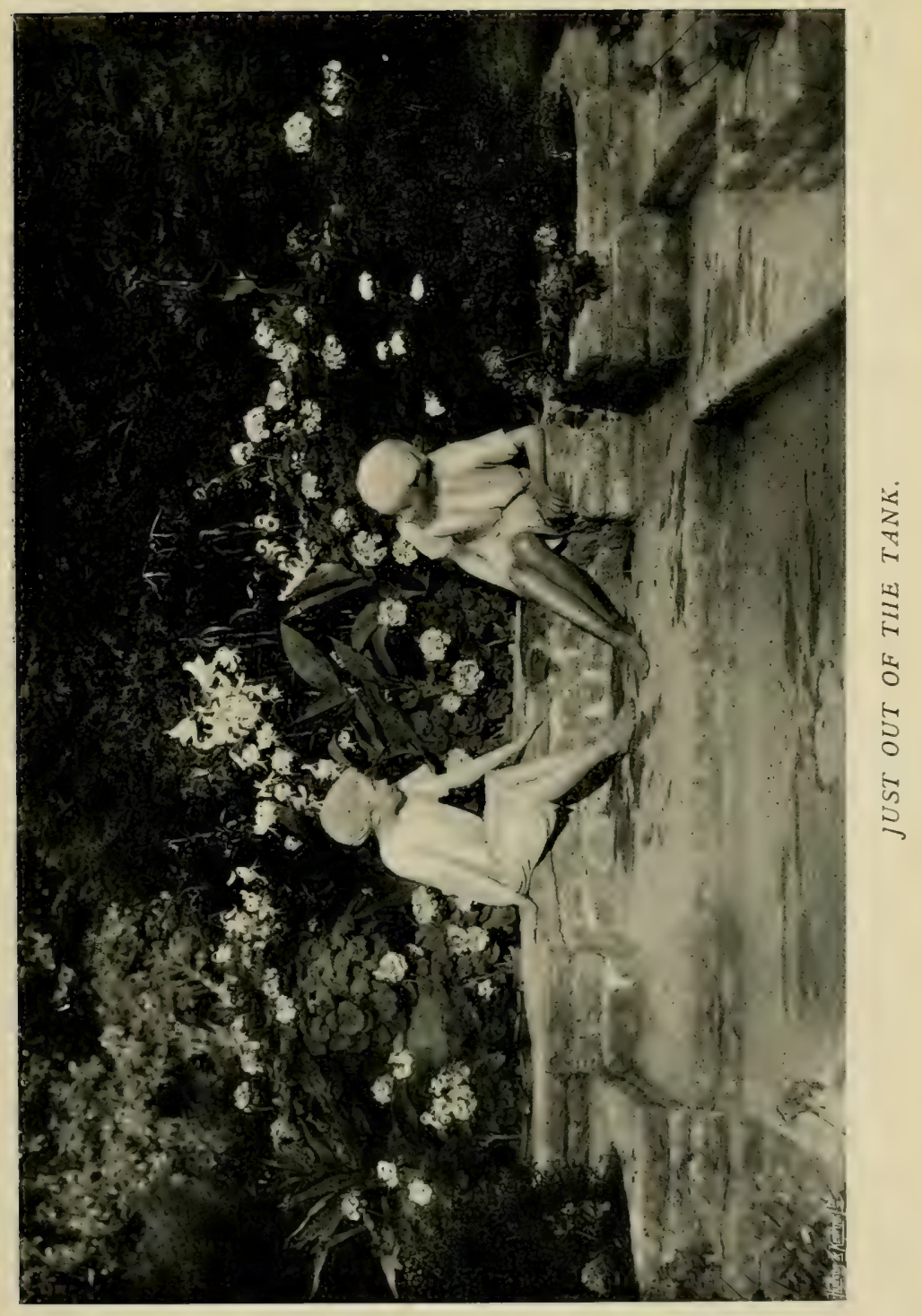




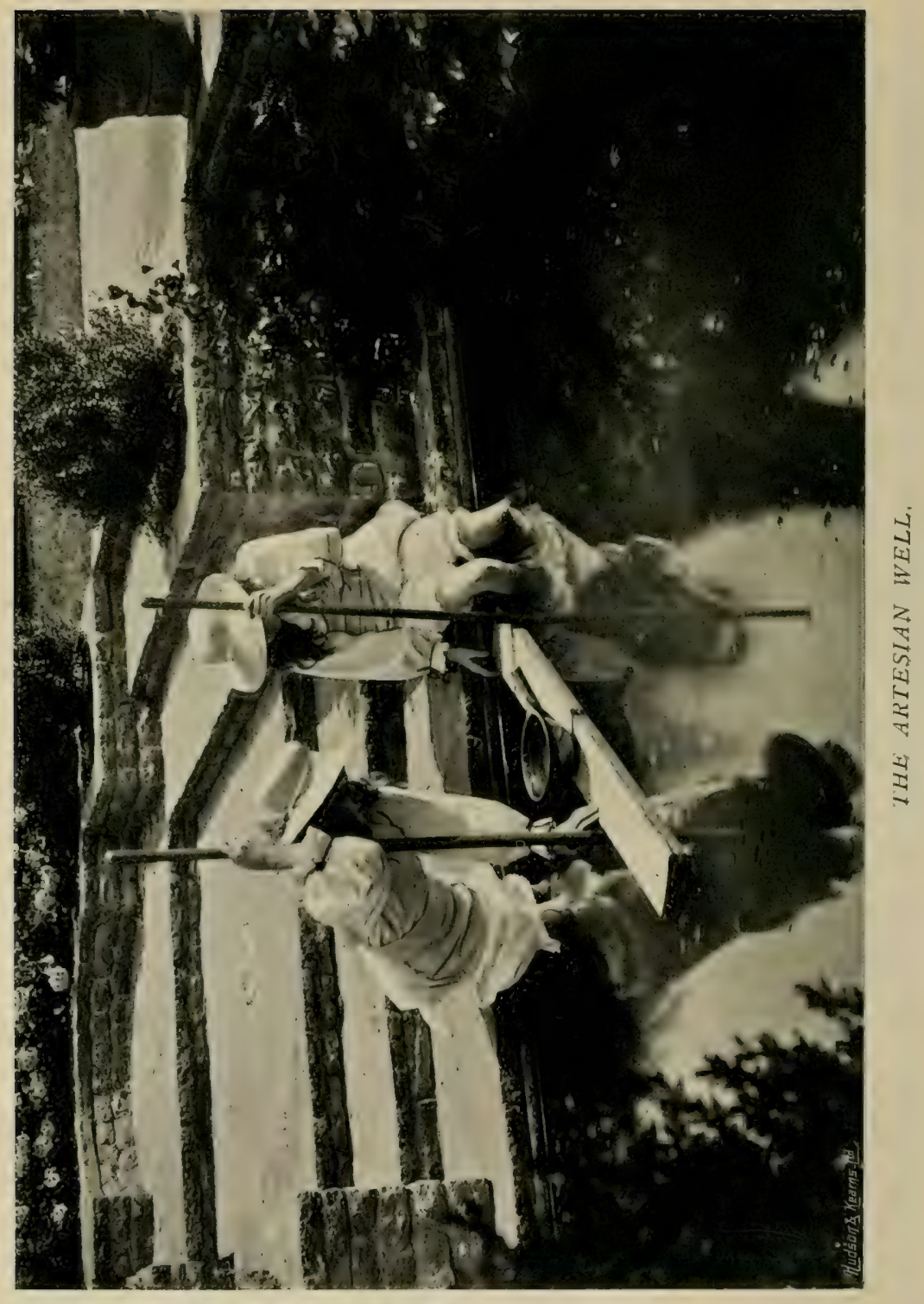


get on the plank and then jump out. One day when they were in the tank-not bathing, as they did sometimes, but only paddling - I found they had borrowed a hand-bowl from my workshop close by, and having filled it with water were sailing it backwards and forwards across the tank. "Look," they said, "this is an artesian well; it is crossing the Channel, sent by the King as a present to the President of the French Republic. You know we have just been learning all about artesian wells." I complimented them on having so accurately grasped the idea of the nature and properties of artesian wells, and only wished I were another of their size, that I too might paddle in the tank and delight in my funny imaginings. 


\section{CHAPTER XII}

\section{PUSSIES IN THE GARDEN}

MY garden would not be half the pleasure it is to me without the pussies. I hope you love them as much as I do. They are perfect garden companions. When I am out at work there is sure to be one or other of them close by, lying on my jacket or on a bench if there is one near. When it is Tabby, if there is an empty basket anywhere handy he is certain to get into it. When I take one of my baskets for flowers-of the pattern that I invented and always use-if I put it down for a moment Tabby takes possession. One day I was bringing the basket home full of Hydrangeas, and put it down to see if there were any figs ripe. I did not see what was going on behind my back, but when I turned round to take up the flowers there he was established in the basket; some of the Hydrangeas were pushed out on to the grass, and Tabby had composed himself to sleep among the rest.

Another day I was doing photographs down the garden with spare plates in a palm-leaf basket. When I wanted more plates he had made himself so comfortable that I could not bear to disturb him, so I went 


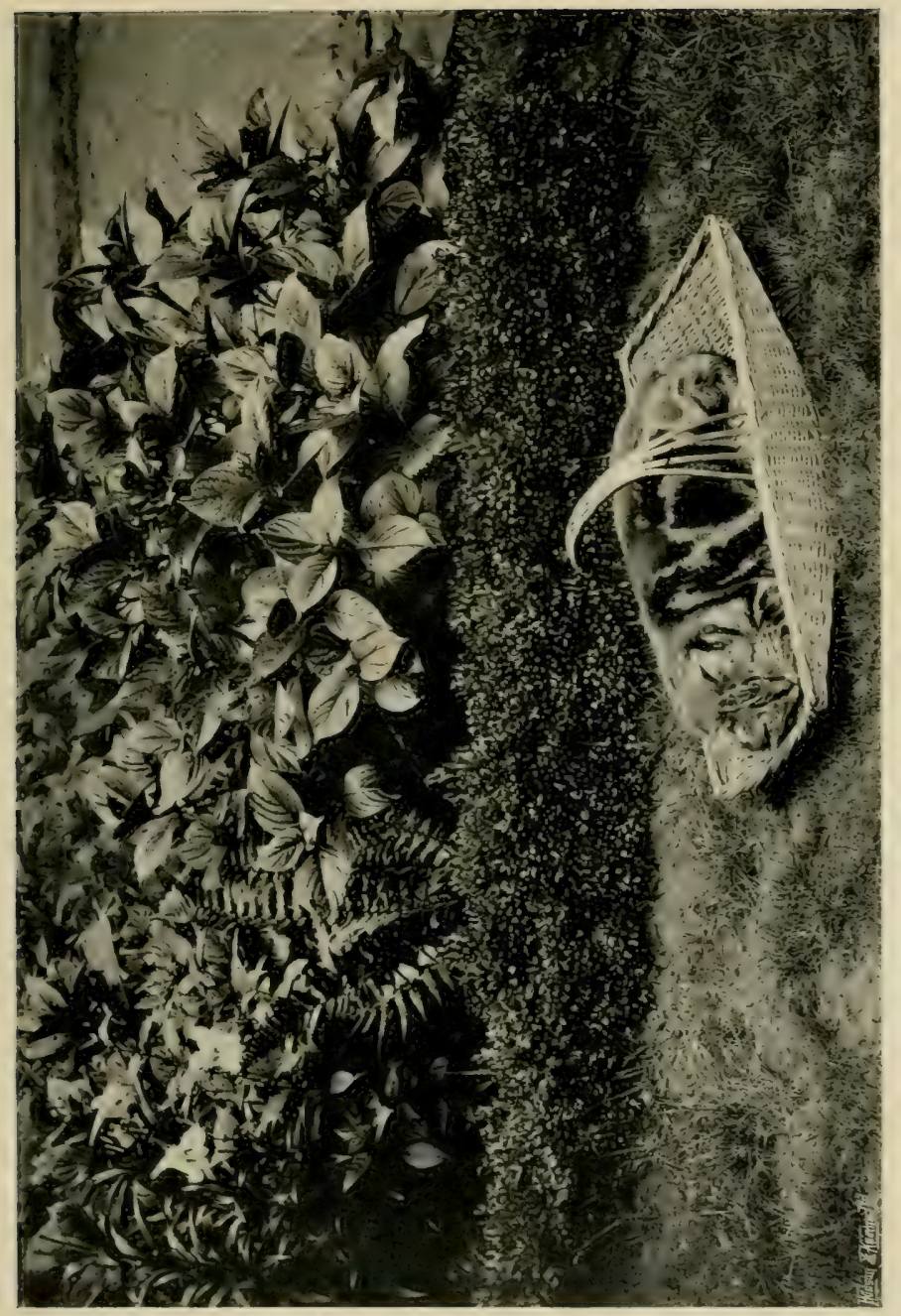

$\vdots$
$\vdots$
$\vdots$
$\vdots$
$\vdots$
$\vdots$
$\vdots$
$\vdots$
$\vdots$
$\vdots$
$\vdots$
$\vdots$ 


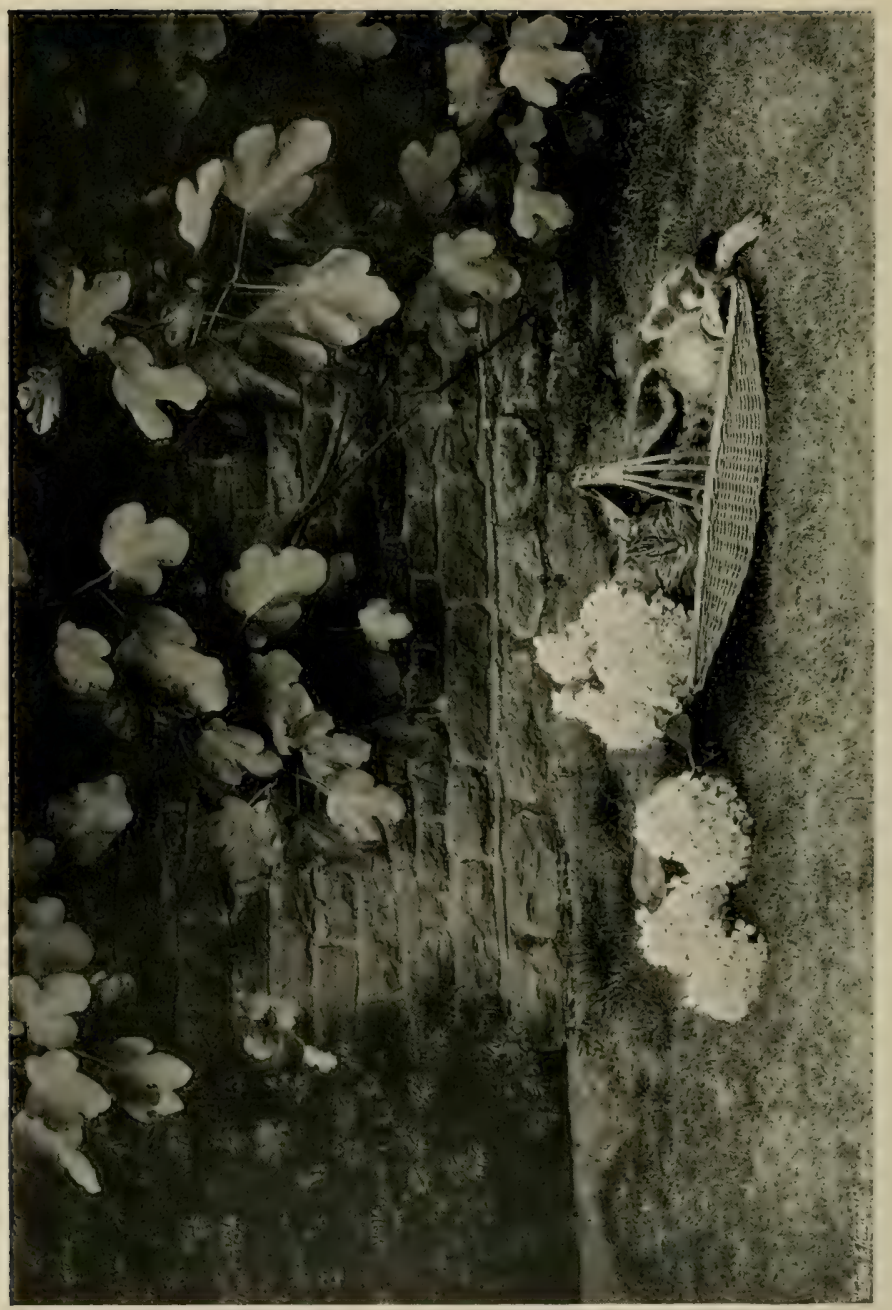

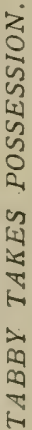




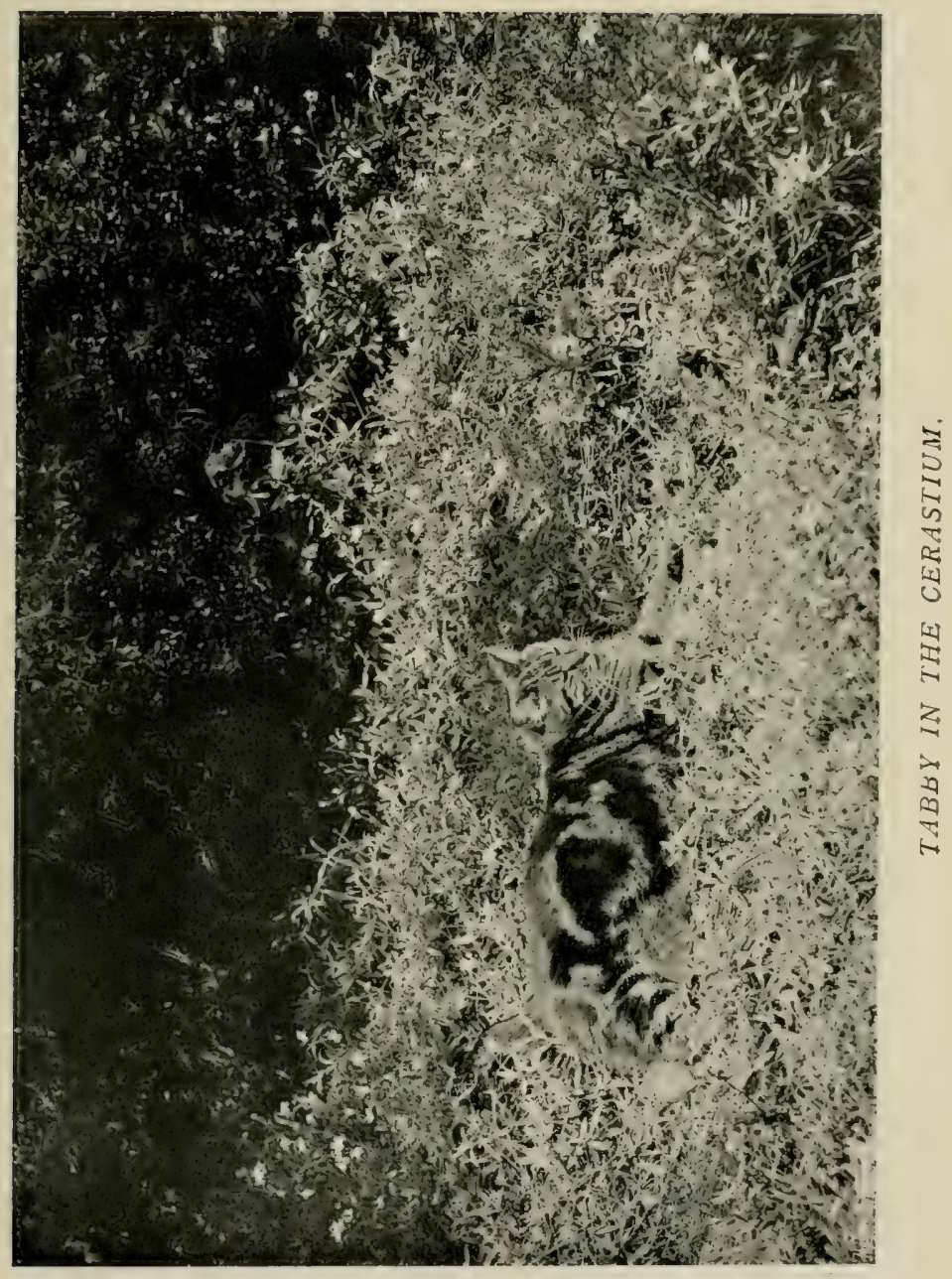



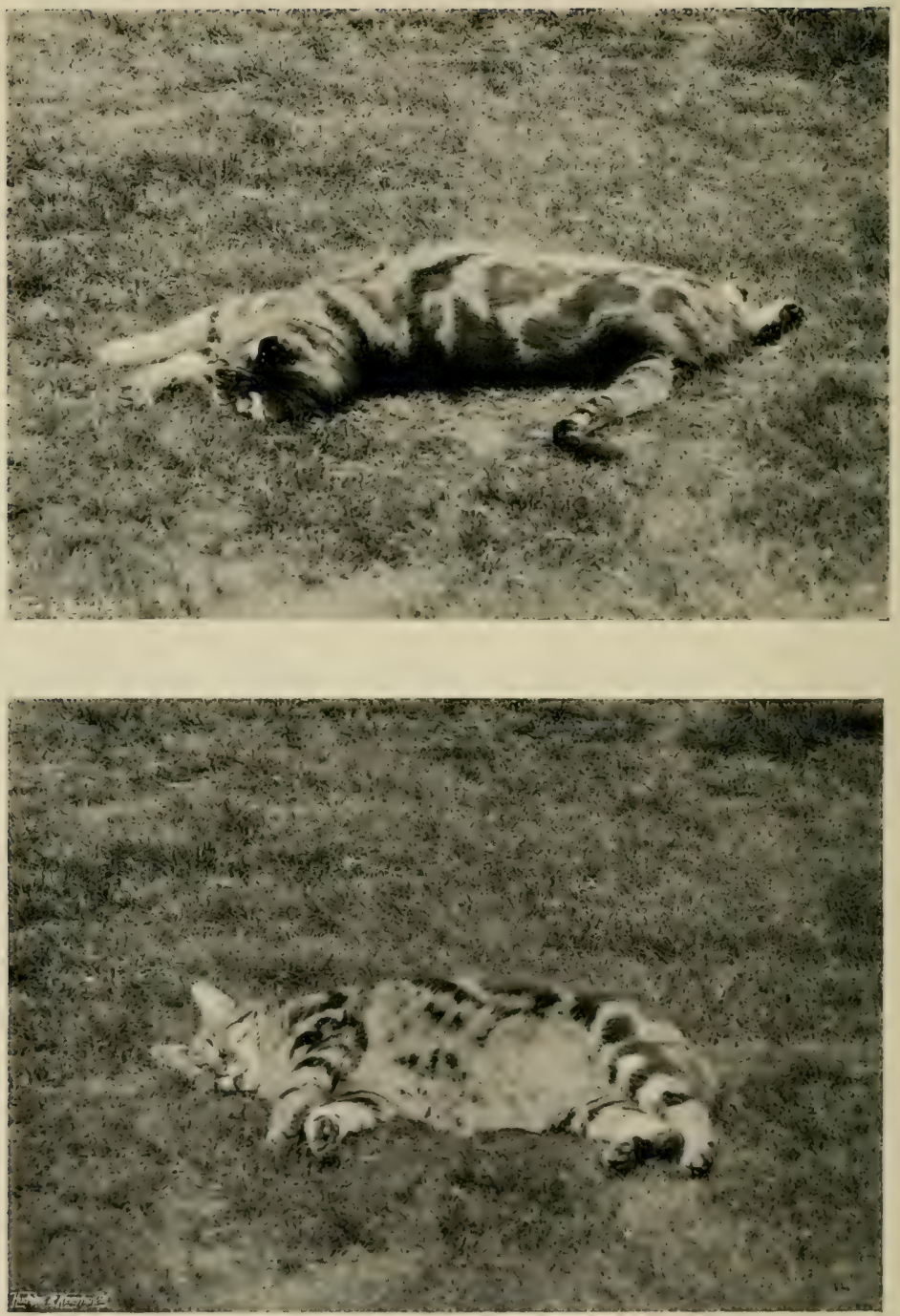

$T A B B Y$. 
indoors and got more plates and made his picture. When I had done one he stretched himself, gave an immense yawn, and settled himself again in a still more reposeful position.

He is particularly fond of the spring garden, where there is a patch of grass and a wooden seat, and Nuttrees and Oaks. It is sheltered and secluded, and there are banks where he can lie in the sun, and cool retreats when it is too hot, and also Yews and Hollies, under which he can always find a dry place when other parts of the ground are damp. One bank is covered with Cerastium; this he thinks is just suitable for his bed. I often find him therc, and though it is not quite the best thing for the Cerastium I cannot help admiring his beautiful rich tabby coat, with its large black clouds, so well set off by the velvety grey of the little downy plant. He is an old pussy now, and when you meet him coming along a path it must be confessed that he is too fat and has lost his figure. But it only shows when he is walking, for when he is sitting, or lying comfortably curled or tucked, and especially when he is on his gate-post, looking out so proud and finehis picture is at the beginning of the book-you would never call him a fat old cat. When he was younger I would hold the gate open, and he would jump from post to post. When I am near his favourite region and do not see him, I call to him; if he does not come at once and I walk on $\mathrm{I}$ am pretty sure to hear him asking where I am within a minute or two.

There is a little bit of turf between the two wings of the house that is another of his favourite haunts. I 
did his picture as he lay stretched out quite flat, asleep, with his back to me, one fine summer day. When I had done I said "Tabby." He just turned straight over, presenting his tummy, and I did the second picture.

Like most cats he is devoted to the pretty plant Catmint. It is in several places in the garden. $\mathrm{He}$ knows where every plant is and never passes one when we are walking together without stopping to nuzzle and nibble it. If I stop to watch him, when he has had his first taste he will push himself right into the middle of the plant and sometimes lie down and roll in it to get all he can of the sweet smell.

But you should see Blackie in the Catmint. He seems to go quite crazy with delight, jumps straight up

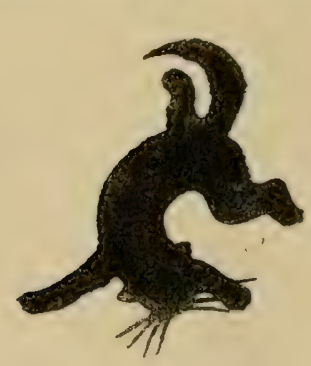
in the air and comes down flop into the middle, dances in it and twists about, and then comes out and does it all over again. $\mathrm{He}$ is only an old kitten as yet, and extremely agile, but the Catmint seems to inspire him with a sort of frenzy of frantic pleasure and excitement. I wish $\because y$ I could have photographed him, (n) enough, and I have to be conBLACKIE AND the CATMint. tent with giving you a sketch from recollection. $\mathrm{He}$ had a pretty trick when he was quite a little fellow; I would hold out my hand about a foot from the ground, 


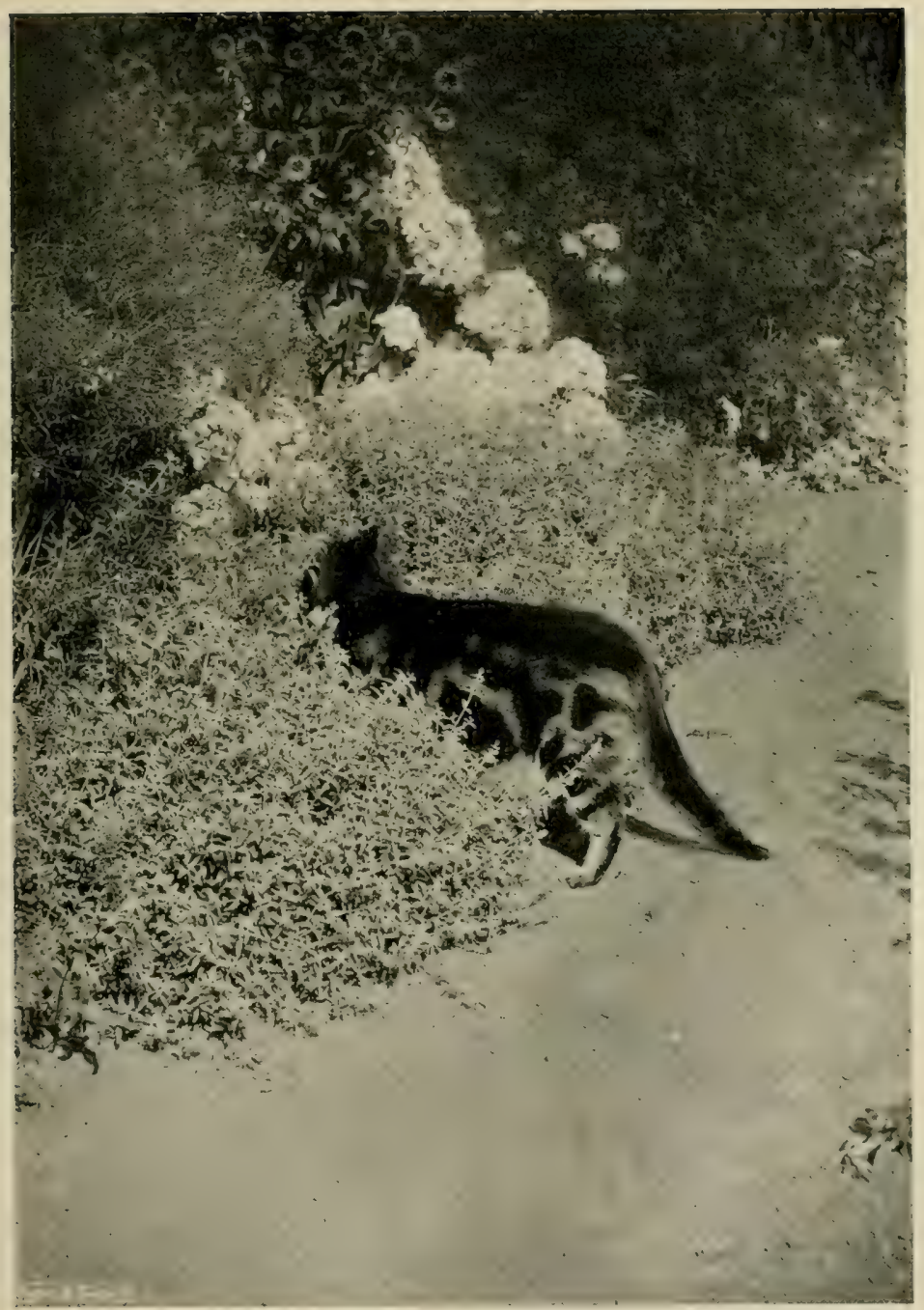

TABBY IN THE CATMINT. "THIS SMELLS I"ERY GOOD." 


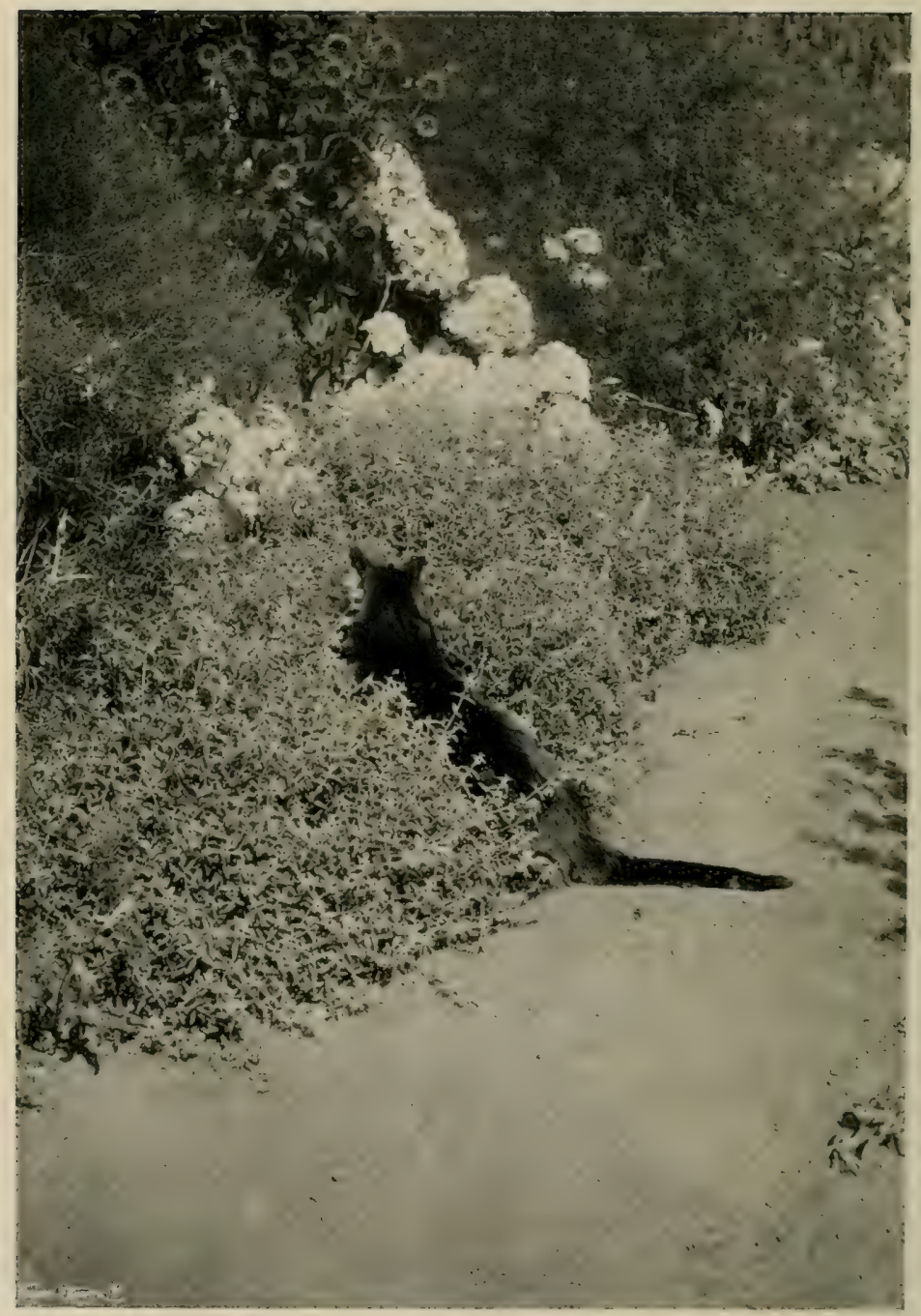

TABBY IN THE CATMINT. "I'LL SIT DOIVN AND HAVE A GOOD NIBBLE." 


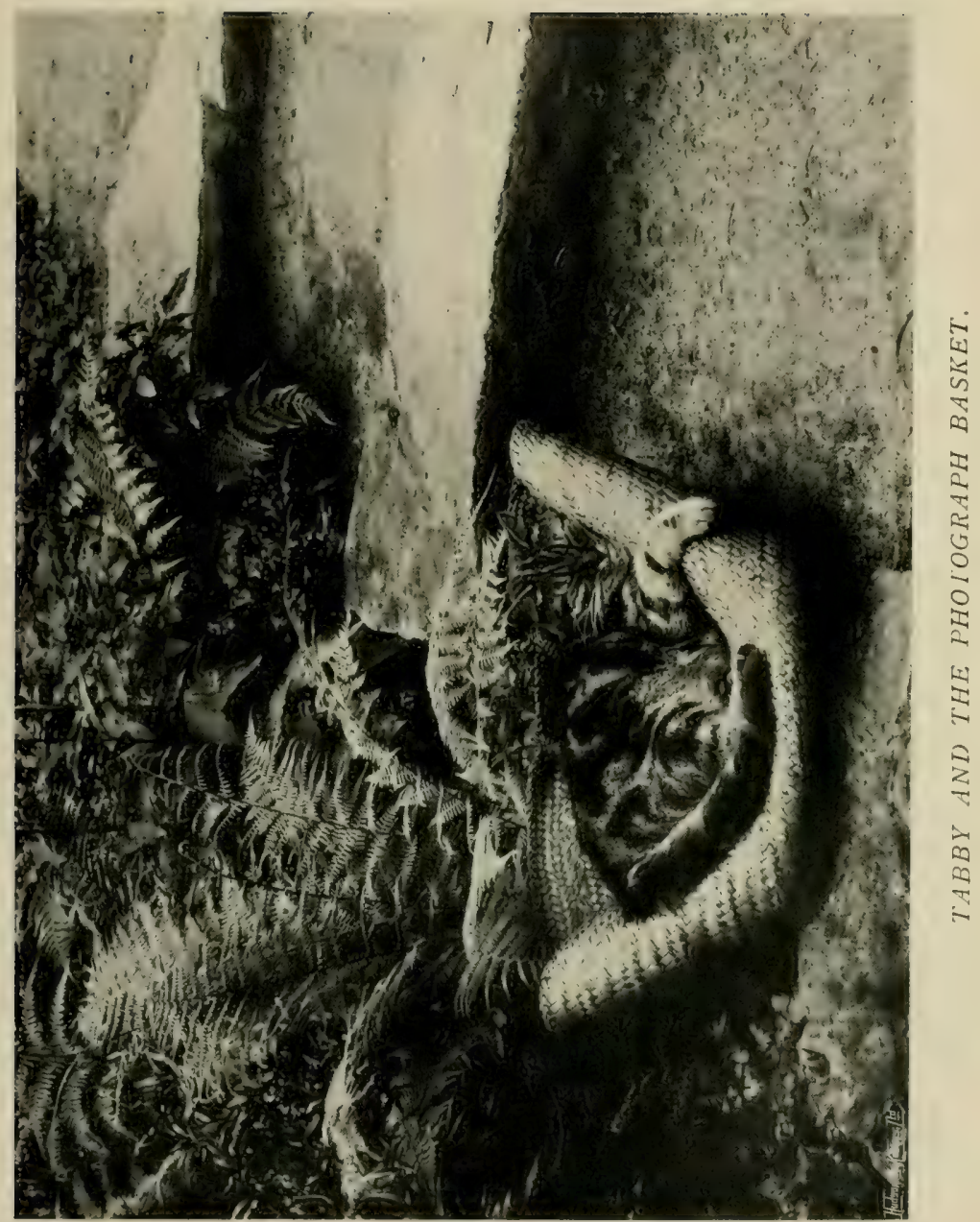




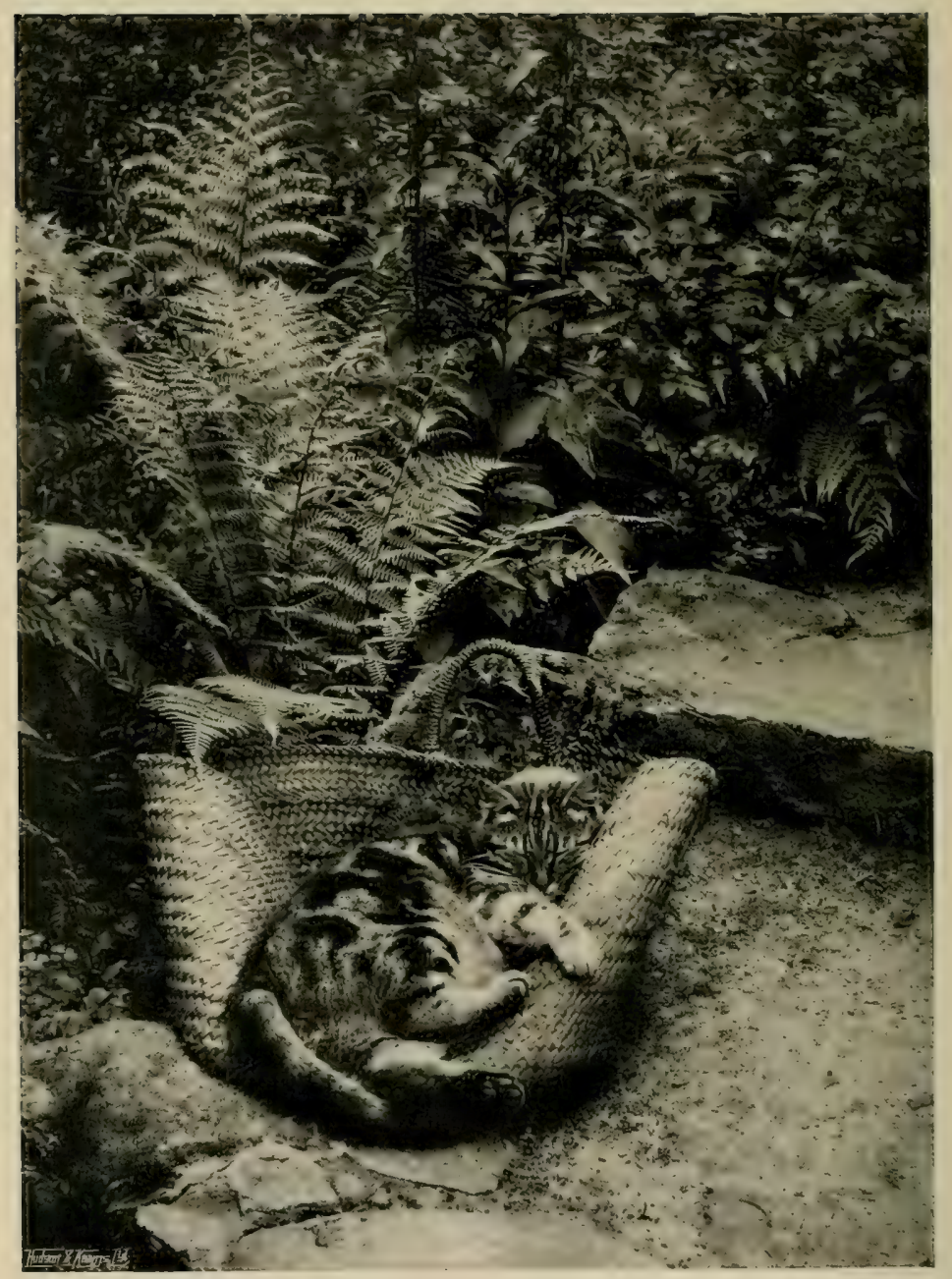

STILL MIORE COMFORTABLE. 
say "Come, Blackie," and he would jump into my hand.

Tittlebat is only too sociable both indoors and out. When I settle mysel: before the fire with a book or newspaper he jumps up on my lap and insists on being petted; pushes the book away with his beautiful sleek head and nuzzles his nose into my hand again and again, and only consents to be quiet when I have given him the amount of attention that he considers his due. One day I had to go to the Rectory as it was getting dark, and did not know that he was following me. The way is across the lawn and through a region of Oaks and Hollies, then through the frame yard and all the length of the kitchen garden, past some Quincetrees and out into the main road by the gardener's cottage. It is not far beyond that to the Rectory. When I came back it was quite dark. Passing the Quince-trees I heard a disturbance in one of them, and something scrambled down to the ground. I thought it was some neighbour's cock or hen gone to roost in the tree, but the thing said May-ow, and I knew my dear Tittlebat's voice. He had followed me down and got up into the Quince to wait till I came back.

$\mathrm{He}$ is quite the most affectionate pussy I have ever known, and nothing, except dogs or a strange cat stalking about, has ever been known to ruffle his temper. I brought him as a kitten from the Isle of Wight, where I went one autumn to a farm lodging. I had left a family of little kittens at home, and on arriving felt rather desolate at having no small pussy playmates. But the next morning, to my delight, I 


\section{2}

\section{CHILDREN AND GARDENS}

saw two very shy little faces peeping out of some shrubs and garden plants that were opposite my sitting-room window, with only a narrow strip of grass between. As soon as I had finished my breakfast I went out to try and make friends, but the kittens were very wild; they had never been tamed or handled. There was a Dahlia just in front of my window at the edge of the bushes. One of its branches stuck out a little, and to this I tied a string with a bit of white paper fastened in the end, so that it swung about. Then I went in and watched. Presently the darker and more handsomely marked of the two little brothers (my future Tittlebat) came out very cautiously and examined the strange object. It moved and he made a dart at it, which made it swing still farther. $\mathrm{He}$ soon found out that it was a capital thing to play with. Then his brother came too, and they had a great game. Next morning at breakfast I poured a little milk into a saucer and put it on the grass near the plaything. They came to it by little cautious advances, and lapped up the milk while I stood within sight at the open window. Then I made another plaything, the same as the Dahlia one, only on a stick, like a fishingrod, so that I could play it from the window. After a little hesitation they came to play with it. This was a grand step, because they saw me at the window all the time. Next I put the saucer of milk on the window-sill, and great was my pleasure when Tittlebat came to it. He was the bigger and stronger of the two, and always took the lead. The next thing was to have the milk on a table put close to the window 


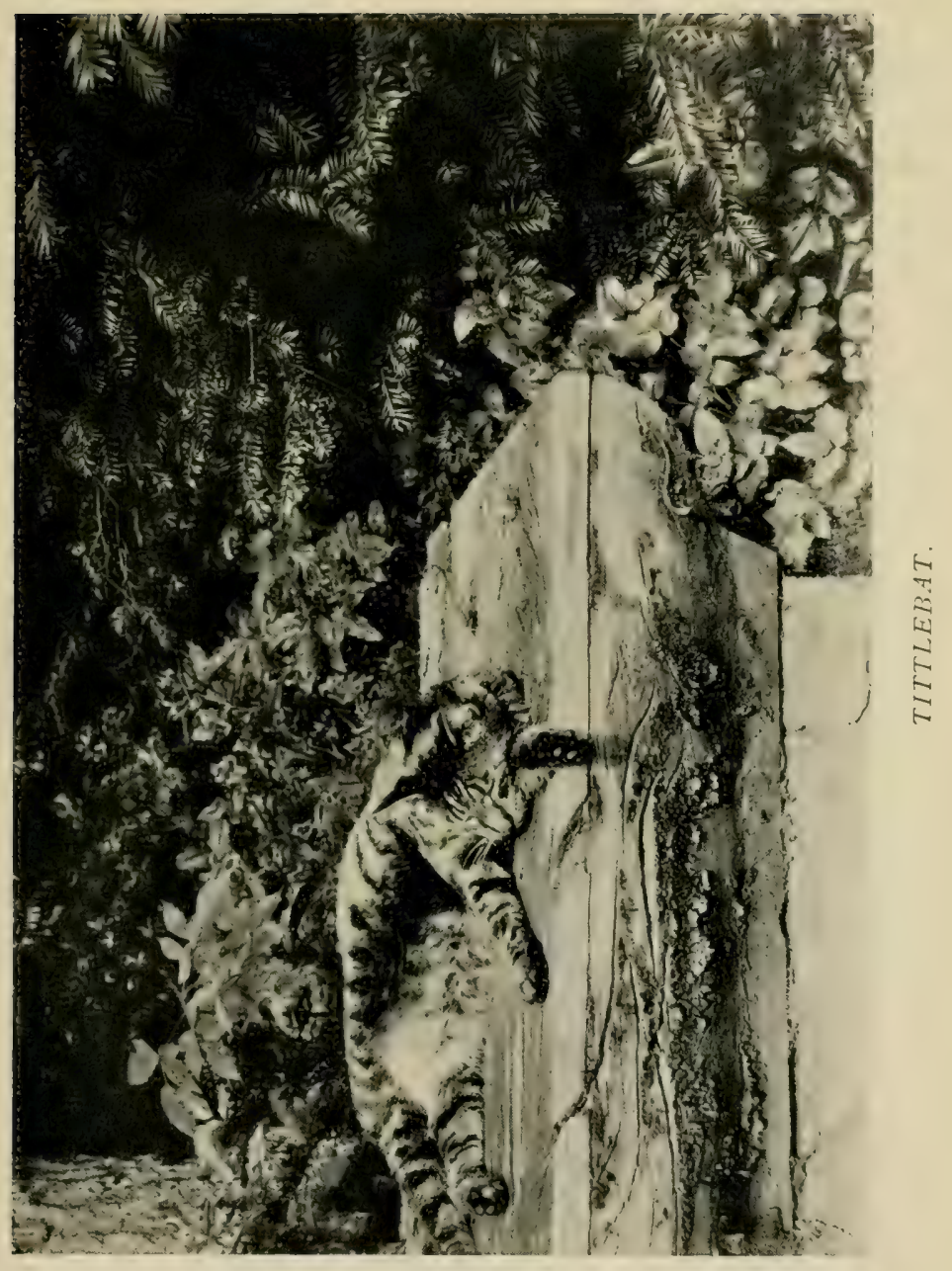




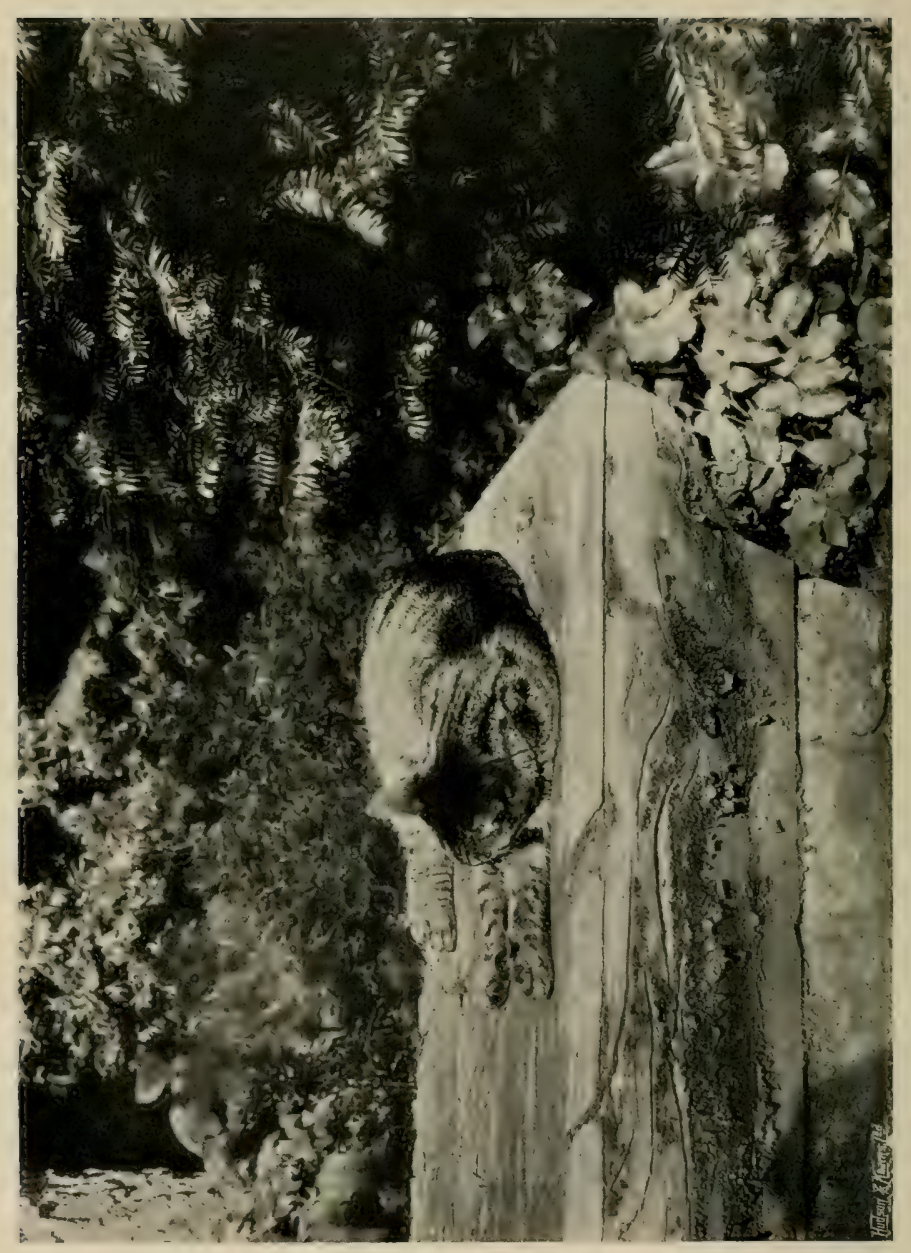

-1
0
0
-1
-1
-1 


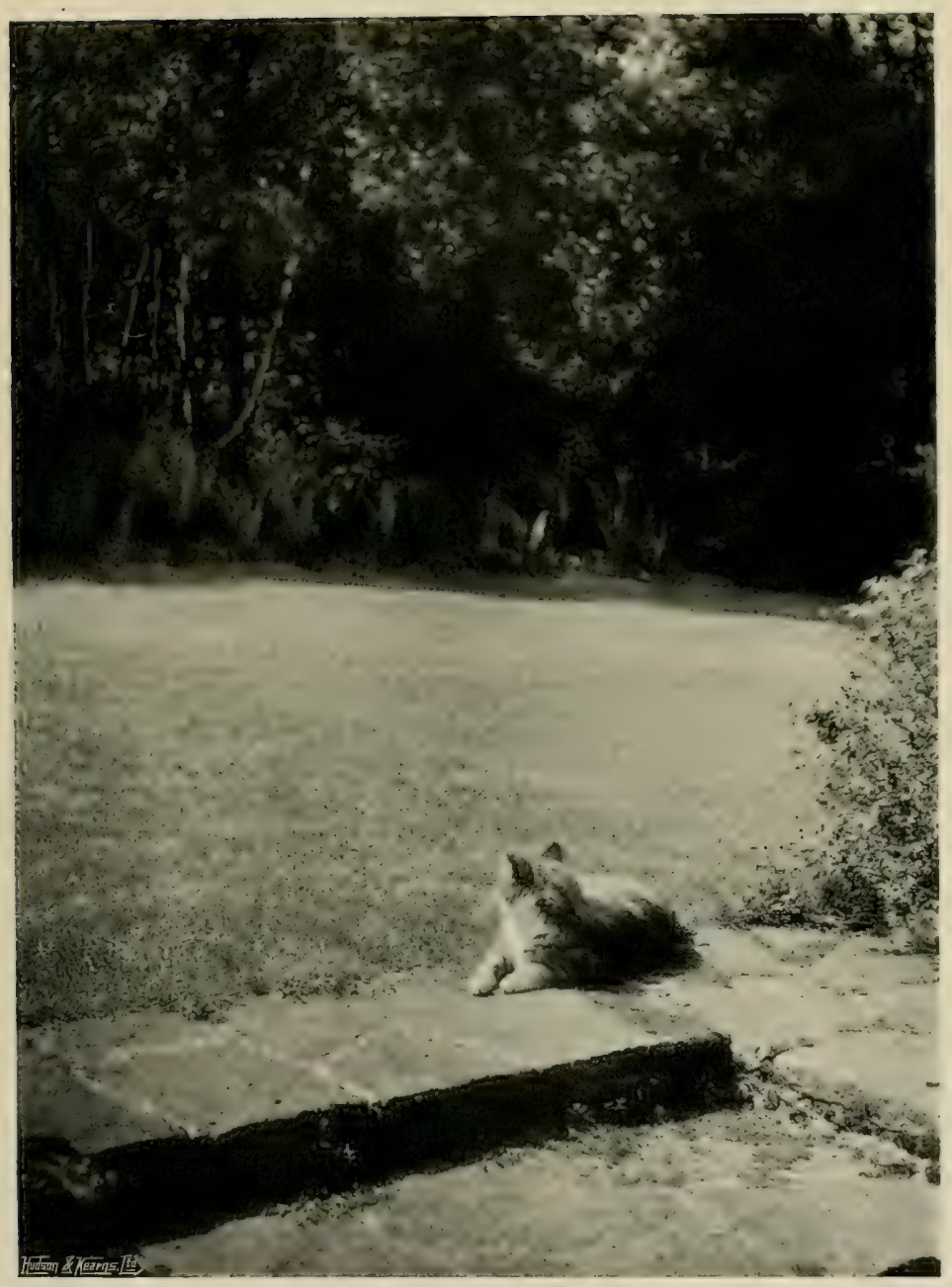

$T A V Y$. 


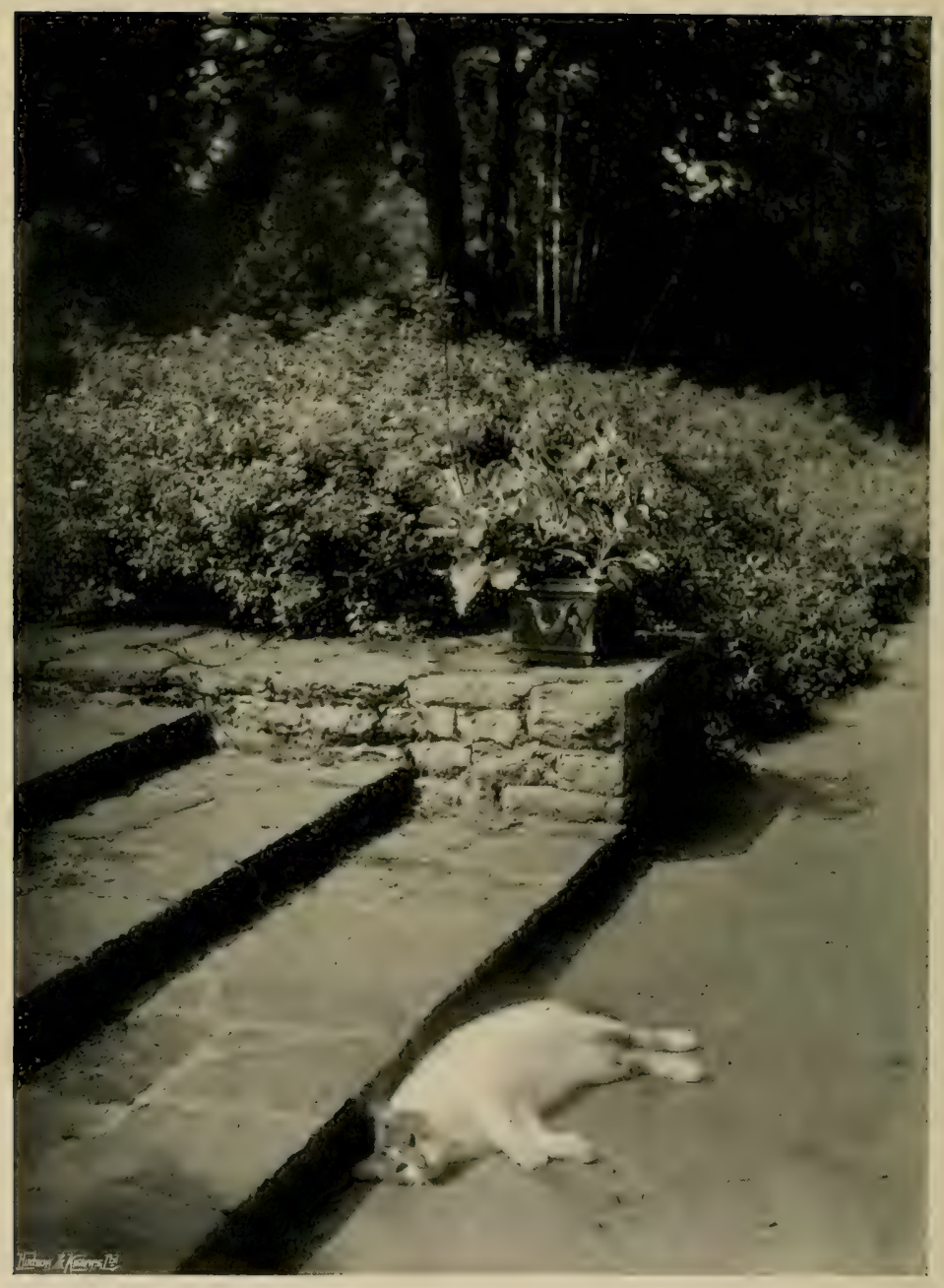

PINKI. 
inside the room. They were attracted to it by means of the plaything, played first on the grass and then on the window-sill. They came up and on to the table, This was a great advance, and while they were lapping I just stroked them a little, very gently, taking care to bring my hand near them very slowly. A quick movement would have frightened them. Then I knew that I had got their confidence. I think this was about five days after the first offer of friendship. Then I pretended to take no notice of them, but you may be sure I was keeping a good watch out of the corner of my eye, and the next day they came up to the window and into the room of their own accord. Before my fortnight was over Tittlebat came to me as a regular thing, sitting on my lap or my shoulder and purring me his little song while I read or worked. You may imagine that when I went away I could not bear to leave him, so I begged to have him and took him home with me, where I at once gave him into the charge of Pinkie, a young pussy of my own rearing only a few months older. They took to each other at once, and very soon became quite inseparable; in fact, if they were ever apart Pinkie was miserable, and would cry most lamentably, looking about for his dear companion.

You might think from his picture that Pinkie was nearly white, but though his white tummy is very extensive all his back is tabby. The tabby comes down into the white on his sides in a way that always makes me think of geography. On the west side two large portions of the Cat-back continent, like two 


\section{IO4 CHILDREN AND GARDENS}

Indias, jut out into the white, which is the Indian Ocean. On the east side there is only one India or South Africa, extending into the Catlantic Ocean, but on his shoulder there is a large blunt promontory, and a nearly round, almost black island, which has a very handsome effect on the ground of white fur.

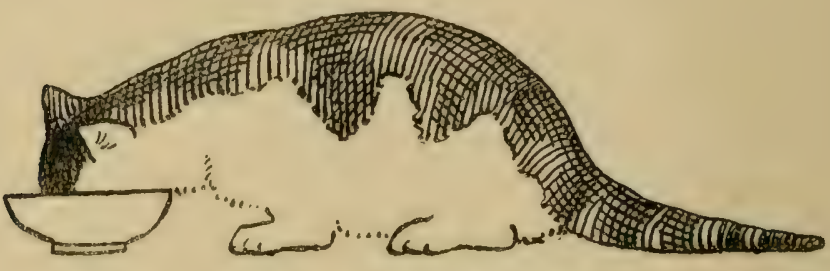

PINKIE WEST ELEVATION

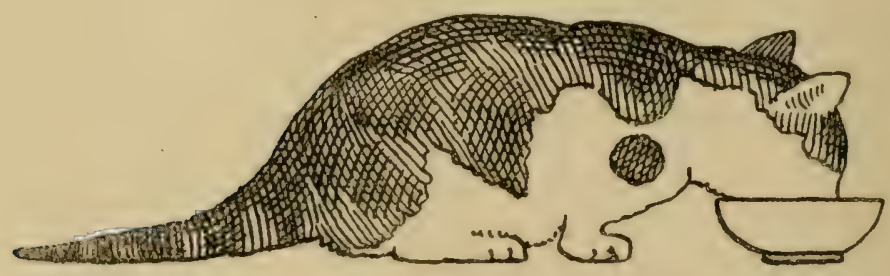

EAST ELEVATION

TWO SIDE ELEVATIONS OF PINKIE.

Tavy is very fond of that place just at the top of the steps opposite the door of the sitting-room to the garden. He likes to sit there when he knows I am near him inside, and keeps an eye on the wood close by, where there are always some objects of interest, if not in sight at least within hearing. He is red tabby and white. He does not come with me so much in the garden as the others, but indoors he is my most 

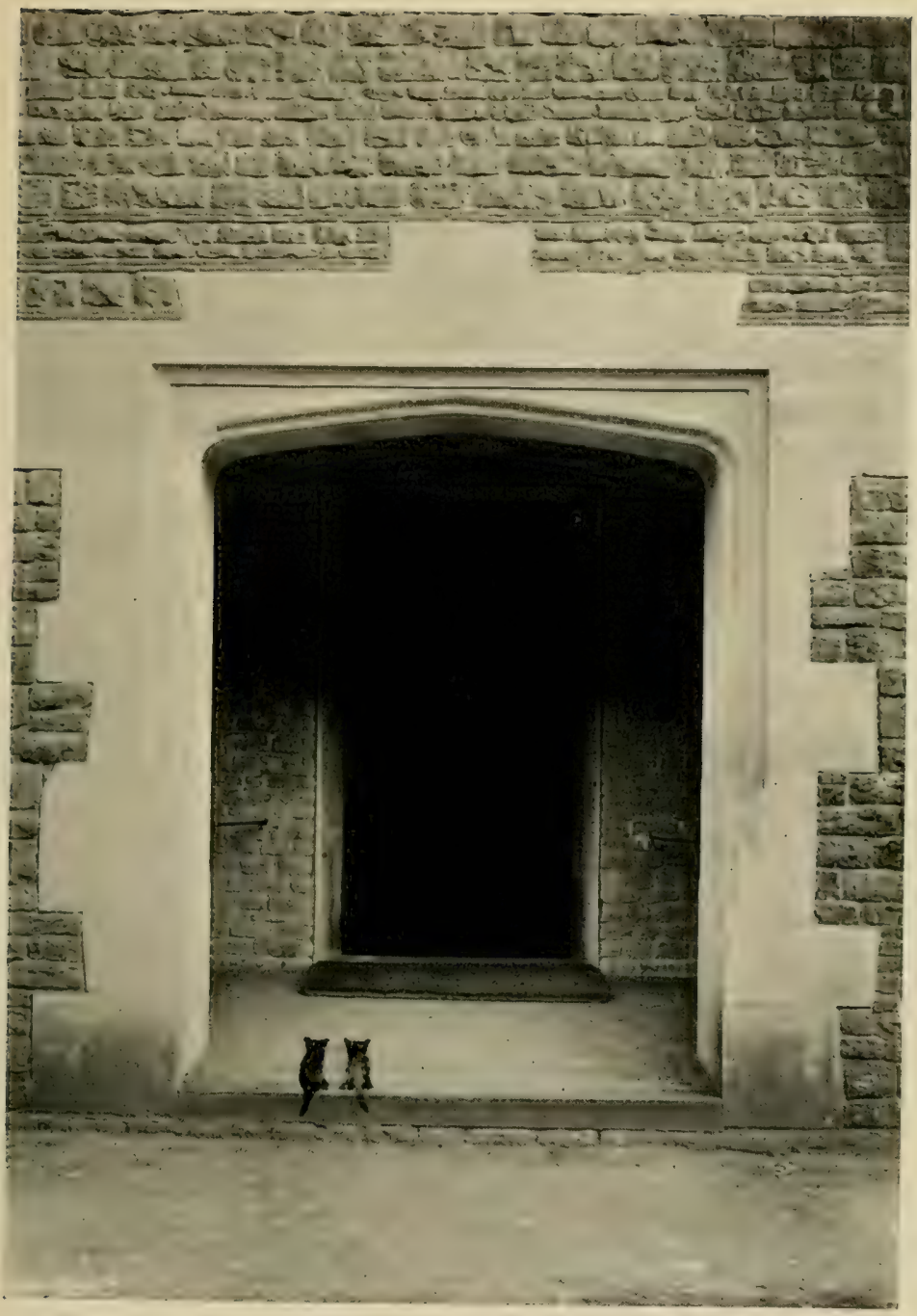

TIVO LITTLE IVAIFS. 


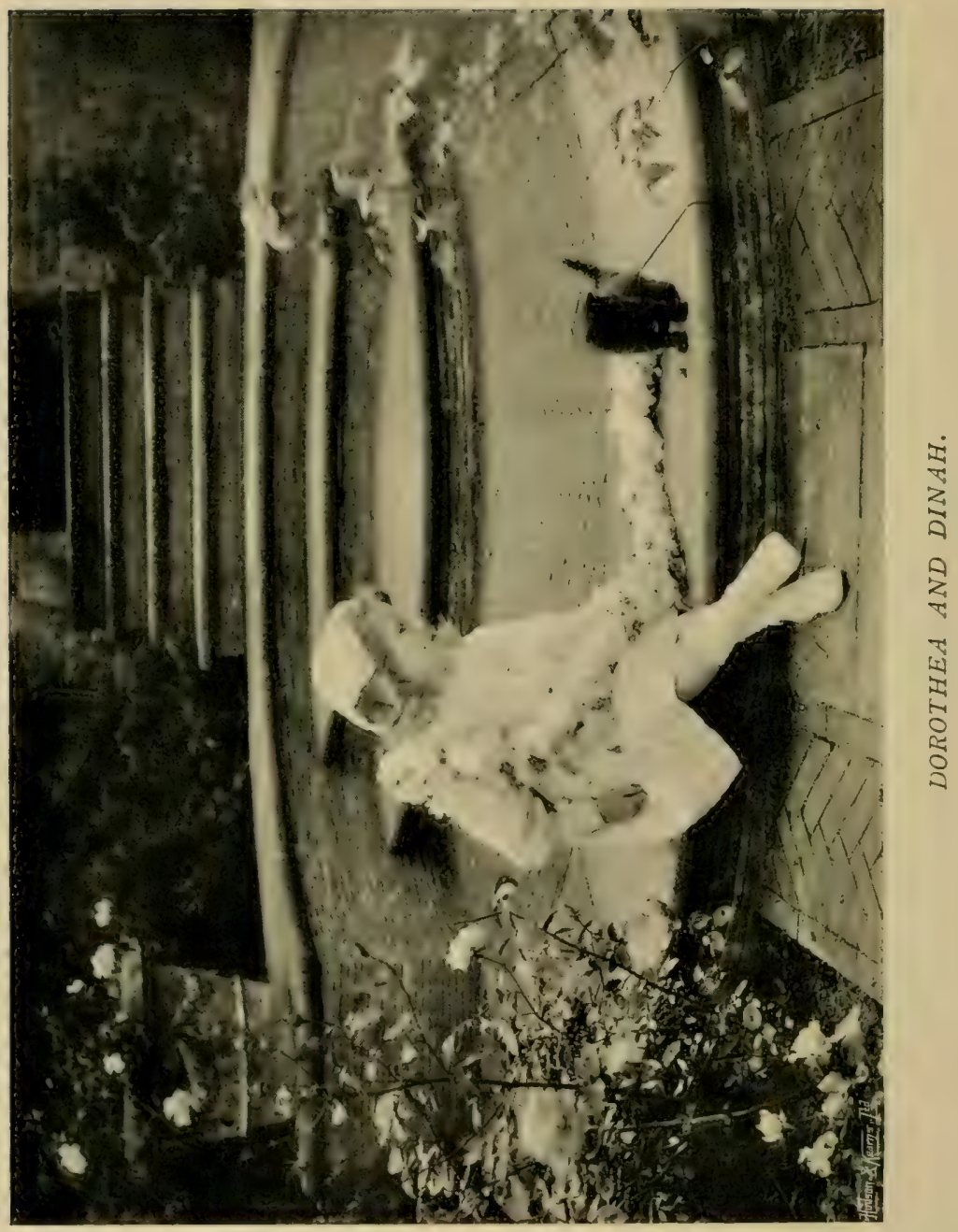


constant companion of all. His fur is deliciously soft and fine, and he has dainty pretty ways, quite little lady-ways, we always say. He has one odd trick that I do not remember having seen in any other cat. $\mathrm{He}$ puffs out his tail when he is pleased-usually a short-haired cat puffs out his tail only when he is frightened, or angry, or fighting. But Tavy makes a beautiful tail when we are playing together, and he is quite pleased with himself and with me. On the rare occasions when he walks with me in the garden--he is jealous, and will never come if any other cat is present, he makes a beautiful tail and walks in a very odd way - a sort of waddling strut; we call it Tavy's ingratiating waddle; purring hard all the time and expecting a great deal of praise and attention.

Dorothea's home is a short mile away. It is a delightful house, with beautiful wild ground and garden all round it. Pussies are much loved there. A curious thing happened. One morning two tiny longhaired kittens, one black and one red, were found on the doorstep, crying with hunger and begging to be taken in. Where they came from, or how they found their way to the house will always be a mystery, for they were baby things, almost too small to have left their mother. No other house is near, and what wonderful instinct guided the little waifs to that kind door no one will ever know. They were cold and starving and bedraggled, as if they had travelled far. They were taken in and fed and cleaned and given warm beds, and very soon became quite strong and lively. When I went there a few days later, to take 
Dorothea a wreath of white roses, the little black kitten was frisking about, and Dorothea said, "Kitty

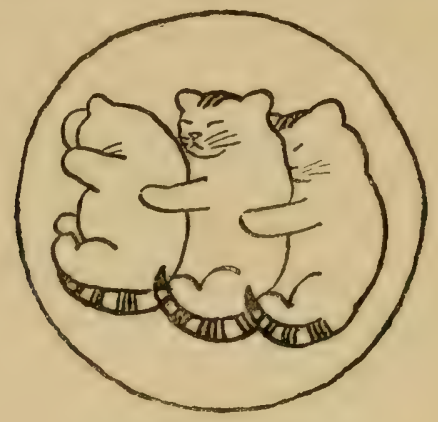

THREE KITTENS-PLAN.

has been trying to climb the Passion-tree." This was a Passion-Flower, with the lower part of the stem grown thick and woody, that grew against the house,

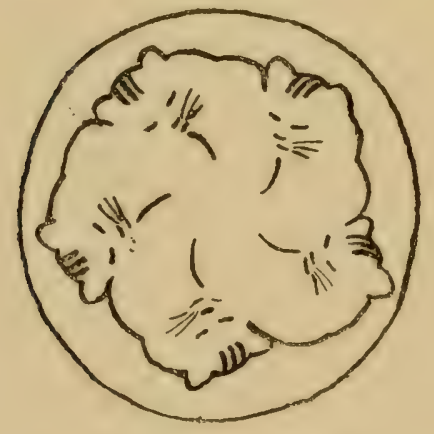

FIVE KITTENS-PLAN.

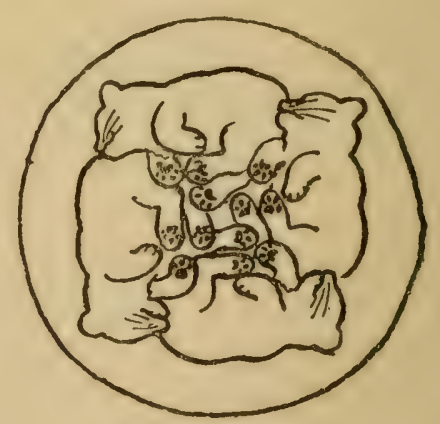

FOUR KITTENS-PLAN.

just beyond these steps of the Dutch Rose garden that you see in the picture.

I was told of a little girl who invented a beautiful 


\section{PUSSIES IN THE GARDEN}

word to describe a pussy purring. She said, "Puss has got the flutter-mill going."

It is amusing to see the different patterns that kittens lying in a round basket will sometimes get into. I have seen five kittens almost symmetrically arranged like cutlets in a dish, and four with their little paws all up in the middle like a pigeon pie. It was almost impossible to believe that only four small people could have so many little toes. Three kittens at nearly equal distances round a saucer of milk make quite a pretty pattern. The architect said it was an equicateral triangle!

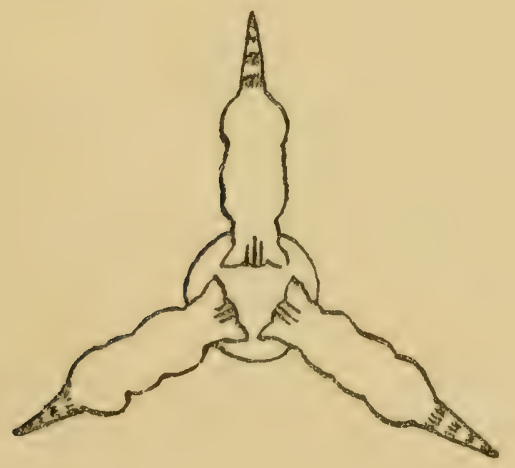





\section{INDEX}

Annuals, 24, 79 ; sowing, 35 ; halfhardy, 76

Arbour Rose, 67

Artesian well, 97

Barberry, 50

Bare feet, 89

Bat, 83

Beer-cooler, 2

Bell-flowers, 6r

Blackie, roo

Blanching, 19

Bonne-femme soup, 19

Botany, 58

Bulbs, 62

Bumble-bee in Snapdragon, 6r

Burn-heap, 93

Campanulas, 6r, 78

Catmint, 100

Chantarelle, 85

Chervil, I7

Children's gardens, 7

Chives, 17

Columbines, 65,77

Composites, 60

Cowslips, 44

ball, 44,47

Cress, Hairy Bitter, 25

Crowns, 30

Cruciferæe, 61

Cucumber, Squirting, 32

Daisy-chain, 4 family, 60
Dandelions, 4, 28

Devil-in-a-bush, 4 I

Dock, 28

Dodder, 84

Elevation, 70

Ellipse, to draw, 73

Euclid, 73

Fairy cakes, 23

Ferns, 3, 65

pegs, 9 I

Figwort tribe, 61

Fir-cones, 33, 91

Fire, picnic, 93

Forget-me-not, 3

Foxglove, 61, 65, 77

Freaks in flowers, 55 ; in fruits, 56

Gudgeons, 2

Hard-head, 68

Hedgehog, 8I

Honesty, 4I

Husks on seed-leaves, 39

Hut, 69

Johns' Flowers of the Field, 63

Julienne, 18

Kalmia, 53

Kittens, I05

Knots, 80

Labels, 37 


\section{Labiates, $6 \mathrm{I}$}

Latin names, 64

Lavender, 6I

Lawn, 8I

Lettuces, 15

London days, 3

Love-in-a-Mist, 4I

Marsh Marigolds, 3

May-day trophy, 45

Mechanical drawing, 72

Mill-pond, 2

Monstrosities, 55

Morell, 48

Mushrooms, 85

Mussels, fishing for, $5 \mathrm{I}$

Mustard and Cress, 14

Owl, 86

Paving, plants in, 79

Pea and Bean tribe, 60

Pear freak, 56

Picnic fire, 93

Pinkie, 103

Pinks, 77

Pitcher-plants, 57

Plans, 69

Play-house, II

Potato milk soup, 20

Potatoes, roasted in ashes, 93

Pricking off, 38

Primrose freak, 56

Pussies, 98

Right angle, to draw, 74

Rose family, 59

Rosemary, 6 I

Roses, 67, 78

Rule of thumb, 73

Sage, 6r

Salad, 16

Sand-martins, 90

Sand-pit, 89

Scale, 72

Scones, 22

Scrambled eggs, 2 I

\section{Section, 70}

Seed-pods, 4I

Seeds, 3r ; of Gourd, 31 ; Broad Bean, 3I; Hawkweed, 33 ; Clematis, 33; Scotch Fir, 34; Sycamore, 34

Sensitive stamens, 50, 54

Shapes of leaves, 54

Shrubbery, 5

Smells and shapes, 49

Snapdragon, 6i dressed as old woman, 42

Sorrel, 20

Soups, I7

Sowing seeds, 35

Spring flowers, 66, 76

Square, builder's, 75

Stalactites, 87

Steps, plants in, 79

Summer flowers, 77

Sweet-smelling leaves, 53

Tabby, 98

Tank, bathing and paddling in, 97

Tarragon, 17

Tavy, 104

Tea in the play-house, I 3

Tea-kitchen, 94

Thistle, 30

Tittlebat, IOI

Toadflax, 6 I

Toadstools, 85

Tools, 8

Tortoise, 83

Tulips, 76

Umbelliferæ, 62

Vegetables, I4

Washing dolls' clothes, 23

Water, playing with, 96

Weeds, 24, 34

Wild flowers, 2, 63

in lawn, 84

Young days, my own, I 



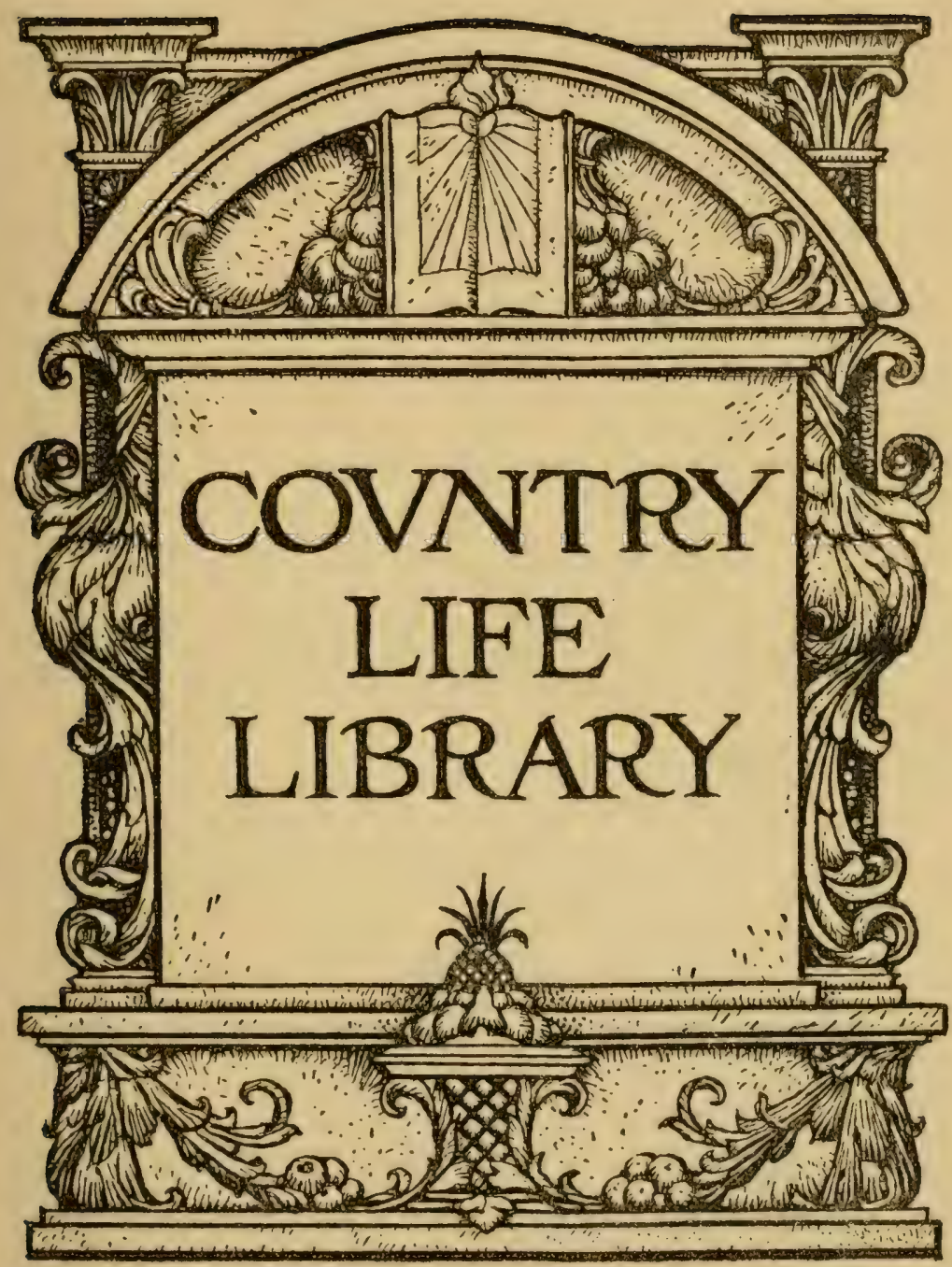




\section{THE CENTURY BOOK OF GARDENING.}

Edited by E. T. Cook, Editor of "The Garden," and Garden Editor of "Country Life." A Comprehensive Work for every Lover of the Garden. 624 pages, with about 600 Illustrations, many of them full-page 4to. (I2 in. by $8 \frac{1}{2}$ in.). Art Canvas.

2Is. Net; by post, 21s. rod.

"No department of gardening is neglected, and the illustrations of famous and beautiful gardens and of the many winsome achievements of the gardener's art are so numerous and attractive as to make the veriest cockney yearn to turn gardener. If THE CENTURY BOOK OF GARDENING does not male all who see it covet their neighbours' gardens through sheer despair of ever making for themselves such gardens as are there illustrated, it should, at any rate, inspire everyone who desires to have a garden with an ambition to make it as beautiful as be can." -Times.

\section{GARDENING FOR BEGINNERS.}

(A Handbook to the Garden.) By E. T. Cook, assisted by Experts in the various branches of Horticulture. With nearly one handred diagrams in the tert, and ninety full-page Illustrations from photographs of selected specimens of Plants, Flowers, Trees, Shrubs, Fruits, etc. New and enlarged Edition.

I2s. $6 d$. Net; by post, I2s. Iod.

"One cannot speak in too high praise of the idea that led Mr. E. T. Cook to compile this GARDENING FOR BEGINNERS, and of the completeness and succinctness with which the idea has been carried out. Nothing is omitted. . . . It is a book that will be welcomed with enthusiasm in the world of gardeners. Post.

One only regrets that the book was not published years ago."-Morning

"One of the handsomest and one of the most useful of its kind that we have come across. GaRDENING FOR BEgINNERs justifies its title, and can be highly commended. A very charming feature of the book is the fine illustrations, of which there are a large number." -Westminster Gazette.

\section{MY GARDEN.}

By EDEN PHilipotTs. I2s. $6 d$. Net; by post, I2s. Iod.

"It is a thoroughly practical book, addressed especially to those who, like himself, have about an acre of flower garden, and are willing and competent to help a gardener to make it as rich, as harmonious, and as enduring as possible. His chapters on irises are particularly good." -World.

.. . . will attract no less for its literary charm than for the varied and interesting experiences which it details. . Mr. Phillpotts is a gardener every inch of him, whatever else he may be, and his book is not only a sound contribution to the literature of gardens, but withal a very captivating one." Wesininster Gazette.

\section{THE FRUIT GARDEN.}

\section{By GEORGE BunYard and OWEN ThOMAs. 507 pages.}

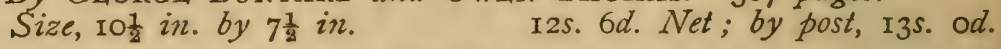

"Without any doubt the best book of the sort yet published. There is a separate chapter for every kind of fruit, and each chapter is a book in itselfthere is, in fact, everything that anyone can need or wish for in order to succeed in fruit growing. The book simply teems with illustrations, diagrams, and outlines. The diagrams on pruning are particularly admirable, we cannot speak too highly of them, and from them anyone should be able to teach himself to be an expert pruner. The book winds up with Ioo pages of outline drawings, which should be a wonderful aid to identification. "-Journal of the Royal Horticultural Society.

Published at the Offices of Coontry LIIE, LTD., 20, Tavistock Street, Covent Garden, W.C., and by GEORGE NEWNES, LTD., 7-12, Southampton Street, Strand, W.C. 


\title{
WALL AND WATER GARDENS.
}

By GERTRUDE JEKYLI. Containing instructions and hints on the cultivation of suitable plants on dry walls, rock walls, in streams, marsh pools, lakes, ponds, tanks, and zuater margins. With $\mathrm{I}_{33}$ full-page Illustrations. Large 8vo, I86 pages. Buckram.

$$
\text { I2s. 6d. Net; by post, i2s. IId. }
$$

" Wall and Water Gardens. He who will consent to follow Miss Jekyll aright will find that under her guidance the old walls, the stone steps, the rockeries, the ponds, or streamlets of his garden will presently blossom with all kinds of flowers undreaned of, and become marvels of varied foliage. More than a hundred photographs help to enforce Miss Jekyll's admirable lessons." - The Times.

"Miss Jekyll shows us how the straight terrace and steep places and hard dry walls may blossom as a rose, and up and down the stone steps our feet walk on a carpet of moss and verdure, and sweet-scented things are at our side to pick."-Spectator.

\section{TREES AND SHRUBS FOR ENGLISH GARDENS.}

By E. T. Coor.

I2s. $6 d$. Net; by post, I2s. ird.

" It contains a mass of instruction and illustration not always to be found altogether when required, and as such it will be very useful as a popular handbook for amateurs and others anxious to grow trees and shrubs. The work would be a welcome present to anyone fond of shrubs and trees, and it well deserves a place in every good garden and country house library."-The Field.

\section{COLOUR IN THE FLOWER GARDEN.}

\begin{abstract}
By GERTRUDE JEKYLL. With over 100 Illustrations and planting plans.

I2s. $6 d$. Net; by post, I3s.

"Miss Jekyll is one of the most stimulating of those who write about what may be called the pictorial side of gardening. . . . She has spent a lifetime in learning how to grow and place flowers so as to make the most beautiful and satisfying effects, and, as far as the fruits of such an experience can be imparted, she has imparted them in these delightful pages." - Daily Mail.
\end{abstract}

\section{ROSES FOR ENGLISH GARDENS.}

By GERTRUDE JEKYL, and E. MAWLEY, with 190 full-page Illustrations. i2s. $6 d$. Net; by post, I2s. IId.

"The first section is occupied by a description from the pen of Miss Gertrude Jekyll of the many kinds of flowers that are now grown, and of the many ways in which they may be set off. . . . The second part is written by Mr. Edward Mawley, who gives his readers the benefit of his experience and study as a practical rosarian, and tells how the rose should be planted, pruned, and pro. pagated, how cared for during its growth, and how best shown off in exhibitions. . . It appeals with equal force to amateurs and to professional gardeners." - Scotsman.

"A delightful proof of the increased devotion shown to rose-growing is supplied by the latest addition to the COUNTRY LIFE Library, which has for its aim to show 'not only how roses may best be grown, but how they may be most beautifully used, and that will also help the amateur to acquire some idea of their nature and relationships.' There is a happy combination of authorship, for no one can better suggest the artistic value of garden roses old and new than Miss Jekyll, while the Secretary of the Rose Society, Mir. Edward Mawley, is a Rosarian who would satisfy Omar Khayyam."-MTanchester Courier.

Published at the Offices of Codntry LifE, LrD., 20, Tavistock Street, Covent Garden, W.C., and by GeORGE Newwes, Lid., 7-12, Soutbampton Street, Strand, W.C. 


\section{THE DISEASES OF TREES.}

By PROFFSSOR R. HARTIG. Royal 8vo, buckram.

Ios. $6 d$. Net; by post, Ios. Iod.

\section{A GARDEN IN VENICE.}

By F. EDEN. An account of the author's beautiful garden on the Island of the Guidecca at Venice. With 2r Collotype and 50 other Illustrations. Parchment, limp. Ios. $6 d$. Net; by post, Ios. rod.

" We congratulate all who have any relation with the book on the fine taste with which it has been written, illustrated and published."-Morning Post.

"Written with a brightness and an infectious enthusiasm that impart interest even to technicalities, it is beautifully and rarely pictured, and its material equipment is such as to delight the lover of beautiful books." -Glasgow Herald.

\section{LILIES FOR ENGLISH GARDENS.}

Written and compiled by GERTRUDE JEKYLI.

8s. 6d. Net; by post, 8 s. Iod.

"Lilies for English GARDens is a volume in the Country Lifb Library, and it is almost sufficiently high commendation to say that the book is worthy of the journal. Miss Jekyll's aim has been to write and compile a book on Lilies which shall tell amateurs, in the plainest and simplest possible way, how most easily and successfully to grow the Lily-which, considering its great beauty, is not grown nearly so much as might be expected. We certainly think that in the future there will be less neglect of this flower, for after looking at some of the illustrations (all admirable and admirably produced) there will not be many garden owners who will be content to ke Lilyless." - Westminster Gazette.

\section{THE UNHEATED GREENHOUSE.}

By Mrs. K. L. Davidson. $8 s .6 d$. Net; by post, 8s. iod.

"An infinity of pleasure can be obtained from the due use of an unheated house built under proper conditions, and it is the function of Mrs. Davidson's book to provide hints and directions how to build such a house, and how to cultivate the plants that can be cultivated with advantage without artificial beat. The information is conveyed in a form that is easily to be followed, and the methods she puts forward are stated with admirable clearness and practicality. No amateur can fail to profit by this excellent manual, and professional gardeners can avail of it with profit."-Pall Mall Gazette.

\section{FLOWER DECORATION IN THE HOUSE.}

By GERTRUDE JEKYLI. $\quad 6 s$. Net; by post, 6s. $4 d$.

"Miss Jekyll is most suggestive and helpful, the illustrations embracing flowers of every season, rare and common, and, indeed, the wild flower bouquets shown are among the most beautiful, while the practical matters of how to support the flowers and keep them fresh are fully dealt with." - Western Morning News.

\section{CHILDREN AND GARDENS.}

By GERTRUDE JEKYLI. A garden book for children, treating not only of their own little gardens and other outdoor occupations, but also of the many amusing and interesting things that occur in and about the larger home garden and near grounds. Thoroughly practical and full of pictures. $6 s$. Net; by post, $6 s .4 d$.

Published at the Offices of Counrry Lifr, LTD., 20, Tavistock Street, Covent Garden, W.C., and by GeorGe NEwNES, Lid., 7-12, Southampton Street, Strand, W.C. 


\section{SEASIDE PLANTING OF TREES AND SHRUBS.}

By AIFRED GAUT, F.R.H.S. An interesting and instructive book dealing with a phase of arboriculture hitherto not touched upon. It is profusely illustrated, and diagrams are given explaining certain details. Those who have gardens and estates on exposed coasts will find the book of immense assistance, and, judging by the remarks of the writer, it is astonishing the beautiful results that may be achieved on such coasts when sufficient protection is afforded.

5s. Net; by post, 5s. 4 d.

"Mr. Gaut has accomplished a piece of very solid and extremely useful work, and one that may not be without considerable influence upon the future development of coast-side garden work and agriculture."-Liverpool Courier.

\section{CARNATIONS AND PINKS.}

Edited by E. T. Coor.

3s. 6d. Net; by post, 3s. Iod.

"Those who add this volume to their library of garden books will obtain more information concerning the interesting family of garden and wild pinks than is to be found in the majority of books that have come under our notice." Westminster Gazelte.

\section{SWEET VIOLETS AND PANSIES, AND VIOLETS FROM MOUNTAIN AND PLAIN.}

Written by several authorities, and Edited by E. T. Cook. This interesting subject has never been treated in the same way as set forth in this illustrated book. Thereare chapters upon the culture of Sweet $V$ iolets in winter and in the open garden, upon Heartsease and the Tufted Pansies (Violas), and upon the Wild Violets that have been introduced from America and elsewhere. The information is thoroughly practical. It is a dainty gift-book to gardening friends. 3s. 6d. Net; by post, 3s. rod.

"Altogether excellent, and must be useful both to the grower of prize flowers and to the amateur who wishes to cultivate some of the many beautiful Alpine and other species which are so effective as hardy plants in the borders or on rockeries." - The Guardian.

\section{THE BOOK OF BRITISH FERNS.}

By Chas. T. DRUeRY, F.L.S., V.M.H., President of the Britis/ Pteridological Society.

3s. $6 d$. Net; by post, 3s. Iod.

"Has been most carefully done, no fewer than 700 choice varieties are described. The book is well and lucidly written and arranged; it is altogether beautifully got up. Mr. Druery has long been recognised as an authority on the subject."-St.James's Gazette.

\section{GARDENING MADE EASY.}

By the Editor of "The Garden." An instructive and practical gardening book of 200 pages and 23 Illustrations, all showing the way certain garden operations should be performed. Every phase of gardening is included. The beginner will find this a most help ful guide in the cultivation of flowers, vegetables and fruits. It is the A.B.C. of gardening. Is. Net; by post, Is. $3 d$.

"It contains a vast amount of information in easily understood language that will be most helpful to persons who love to look after their own garden." Scotsman.

Published at the Offices of CounrRy LifE, LTD., 20, Tavistock Street, Covent Garden, W.C., and by GEORGE NEWNEs, LID., 7-12, Southampton Street, Strand, W.C. 


\section{GARDENS OLD AND NEW.}

(The Country House and its Garden Environment.) Edited by H. AvRAy TIPPING, M.A., the Illustrations being from Photographs specially taken by CHARLES LATHAM. Crown folio ( 15 in. by Io in.). Handsomely bound in cloth, gilt edges. Vols. I., II. and III. now ready. $£_{2} 2 s$. Net each; by post, $£^{2} 3^{s}$.

\section{The following are the principal Houses llustrated-}

Alton Towers, Staffordshire

Ashbridge Park, Great Berkhamstead

Athelhampton Hall, Dorchester

Barlborough Hall, Chesterfield

Belton, Grantham

Blickling, Norfolk

Brickwall, Sussex

Brome Hall, Norfolk

Broughton Castle, Banbury

Bulwick Hall, Northampton

Casa de Pilatos, The, Seville

Charlton House, Kent

Chatsworth, Derbyshire

Cleeve Prior Manor, Worcestershire

Clevedon Court, Somerset

Clifton Hall, Nottingham

Compton Beauchamp, Berkshire

Condover, Shropshire

Drayton House, Northampton

Elvaston Castle, Derbyshire

Agecroft Hall, Manchester

Albury Park, Surrey

Aldenham House, Herts

Amesbury Abbey, Wiltshire

Balcarres, Fifeshire

Barncluith, Lanarkshire

Barrow Court, Somerset

Brockenhurst Park, Hants

Castle Ashby, Northants

Chastleton House, Gloucestershire

Chirk Castle, Denbighshire

Chiswick House, Middlesex

Compton Wynyates, Warwickshire

Cranborne Manor, Dorset

Drakelowe Hall, Staffordshire

Drumlanrig, Dumfriesshire

Drummond Castle, Perthshire

Easton Hall, Grantham, Lincs

Eaton Hall, Cheshire

Eydon Hall, Northants

Frogmore and Windsor

Grimston Park, Yorkshire

Athelhampton Hall, Dorsetshire South Wraxall Manor, Wiltshire Faulkbourne Hall, Essex

Layer Marney Towers, Essex

Giffords Hall, Suffolk

St. Osyth's Priory, Essex

Speke Hall, Lancashire

Great Tangley Manor, Surrey

Castle Ashby, Northamptonshire

Montacute House, Somerset

Hatfield House, Hertfordshire

Holland House, Kensington

\section{VOLUME I.}

Fountains Hall and Abbey, Yorkshire

Franks, Kent

Great Tangley Manor, Surrey

Guy's Cliff, Warwick

Hall Barn, Buckinghamshire

Hall, The, Bradford-on-Avon

Ham House, Richmond

Hardwick Hall, Derbyshire

Heckfield Place, Hampshire

Henbury Court, Gloucestershire

Heslington Hall, York

Hever Castle, Kent

Holme Lacy, Hereford

Ightham Mote, Kent

Kelly House, Tavistock

King's Weston, Gloucestershire

Kingston Lacy, Dorsetshire

Levens Hall, Westmoreland

Lilleshall, Shropshire

Longford Castle, Wiltshire

Loseley Park, Surrey

Lypiatt Park, Gloucestershire VOLUME II.

Groombridge Place, Kent Gwydyr Castle, Denbighshire

Hackwood Park, Hants

Haddon Hall, Derbyshire

Hadsor, Worcestershire

Hampton Court, Middlesex

Harewood House, Yorkshire

Highnam Court, Gloucestershire

Hoar Cross, Burton-on-Trent, Staffordshire

Inwood House, Somerset

Kedleston Hall, Derbyshire

Kentwell Hall, Suffolk

Leighton Hall, Welshpool

Linton Park, Maidstone, Kent

Littlecote Hall, Berkshire

Lochinch, Wigtownshire

Longleat, Wiltshire

Mapperton House, Beaminster

Margam Park, Glamorganshire

Marks Hall, Essex

Melford Hall, Suffolk

Mere Hall, Droitwich

$$
\text { VOLUME III. }
$$

Bradfield, Devon

St. Catherine's Court, Somersetshire

Canons Ashby, Northamptonshire

Llangedwyn Hall, Denbighshire

Gayburst, Buckinghamshire

Keevil Manor, Trowbridge

Stibbington Hall, Huntingdonshire

Hutton-in-the-Forest, Cumberland

Treworgey, Cornwall

Newton Ferrers, Cornwall

Wilton House, Salisbury
Melbourne Hall, Derbyshire

Montacute, Somerse

Newstead Abbey, Nottingham

Norton Conyers, Yorkshire

Old Place, Lindfield

Panshanger, Hertfordshire

Penshurst, Kent

Prior Park, Bath

Ragley Hall, Warwickshire

Renishaw Hall, Chesterfield

Risley

Rous Lench Court, Worcestershire

St. Catherine's Court, Bath

Shipton Court, Oxford

Stoneleigh Abbey, Warwickshire

Studley Royal, Yorkshire

Sutton Place, Guildford

Sydenham House, Devonshire

Tissington Hall, Derbyshire

Trentham, Staffordshire

Ven House, Somerset

Wilton House, Salisbury

Wollaton Hall, Nottinghamshire

\section{Moyns Park, Essex}

Munstead, Surrey

Newbattle Abbey, Midlothian

Okeover Hall, Derbyshire

Orchardleigh Park, Somerset

Orchards, Surrey

Packwood House, Birmingham

Pain's Hill, Surrey

Parham Park, Sussex

Fenrhyn Castle, N. Wales

Penshurst, Kent

Pitchford Hall, Shropshire

Powis Castle, Montgomeryshire

St. Fagin's, Cardiff

Sedgwick Park, Sussex

Shrubland's Park,-Suffolk

Smithill's Hall, Lancashire

Stoke Edith Park, Heretord

Stoke Rochford, Lincolnshire

The Vyne, Hants

Westwood Park, Droitwich

Wickham Court, Kent

Wilton House, Wiltshire

Bramham Park, Yorkshire

Wrest Park, Bedfordshire

Bicton, Devonshire

Lyme Hall, Cheshire

Castle Howard, Yorkshire

Wotton House, Aylesbury

Bowood, Wiltshire

Arley Hall, Cheshire

The Deanery Gardens, Sonning, Berkshire

Easton Lodge, Essex

Goddards, Surrey

"These beautiful books owe their charm to the wonderful collection of photographs of gardens and garden architecture which such a paper as CoonTRY LIFE has had a unique opportunity of making. The principle conveyed in the letterpress is that held by all great gardeners and architects-that house and garden are, or should be, intimately associated, and that the character of the possessors should be reflected in both. The accounts of lovoly garden after lovely garden are most agreeable reading. There is no country in the world where man created sylvan beauty can be found comparable to this in England, and as albums of charming pictures for the garden lovers and a mine of elegant suggestion to the garden-maker, these volumes are the best thing of their kind we have ever seen."-Daily Chronicle. 


\section{IN ENGLISH HOMES.}

Edited by H. AvRAy Tipping, M.A. The internal character, furniture, and adornments of some of the most notable Houses of England depicted from Photographs taken by CHARLES LATHAM. Vols. I. and II. now ready.

Price $£^{2}$ 2s. each net.

\section{The following are the principal Houses lllustrated in the work:-}

VOL. I.

Agecroft Hall, Lancashire A pethorpe, Northampton Audley End, Essex

Belton House, Grantham Birtsmorton Court, Gloucestershire

Bowood Park, Wiltshire

Boston House, Middlesex

Bradfield, Devon

Bramall Hall, Cheshire

Bramshill Park, Hampshire

Broughton Castle, Oxfordshire

Burton Agnes, Yorkshire

Cassiobury Park, Hertfordshire

Castle Ashby, Northamptonshire

Castle Howard, Yorkshire

Chastleton House, Oxfordshire

Chawton House, Hampshire

Cobham Hall, Kent

Combe Abbey, Warwickshire

Crewe Hall, Cheshire

Drakelowe Hall, Burton-on-Trent

Dunster Castle, Somerset

astnor Castle, Herefordshire

Adlington Hall, Cheshire

Aston Hall, Birmingham

Athelhampton, South Dorset

Baddesley Clinton, North Warwickshire

Beningbrough Hall, Yorkshire

Blickling Hall, Aylsham, Norfolk

Bolsover Castle, Chesterfield, Derbyshire

Burton Constable, Hull, Yorkshire Canons Ashby, South Northants

Chicheley Hall, Newport Pagnell, Bucks

Clouds, South-West Wiltshire

Cotehele, Cornwall

Dorton House, Thame, Oxfordshire

Drakelowe, Burton, Derbyshire

East Sutton Park, Maidstone, Kent

Glynde, Lewes, Sussex

Hanford House, Blandford, Dor. setshire
Gifford's Hall, Suffolk

Godinton, Kent

Goodwood House, Sussex

Grimsthorpe, Lincolnshire

Groombridge Place, Kent

Haddon Hall, Derbyshire

Hampton Court, Middleser

Hardwick Hall, Derbyshire

Hatfield House, Hertfordshire

Hewell Grange, Worcestershire

Holme Lacy, Hereford

Kedleston Hall, Derbyshire

Kingston Lacy, Dorset

Knowsley Hall, Lancashire

Lanhydrock, Cornwall

Levens Hall, Westmorland

Littlecote, Wiltshire

Longleat, Wiltshire

Melbury House, Dorset

Old Place, Sussex

Oxburgh Hall, Norfolk

Parham Park, Sussex

Ragley Hall, Warwickshire

Red Lodge, Bristol

VOL. II.

Hever Castle, Kent

Hill Hall, Epping, Essex

Hoghton Tower, Blackburn, Lancashire

Holland House, Kensington

Hornby Castle, Richmond, Yorkshire

Hutton-in-the-Forest, Penrith, Cumberland

Ightham Mote, Sevenoaks, Kent

Knebworth House, Hertfordshire

Langleys, Great Waltham, Essex

Lyme, Cheshire

Marshcourt, Stockbridge, Hampshire

Maxstoke Castle, North Warwickshire

Methley Hall, Leeds

Newburgh Priory, Yorkshire

No. 12, Welshback, Bristol

Park Hall, Oswestry, Salop

Prinknash Park, Gloucestershire
Rufford Abbey, Nottinghamshire

Rushbrooke Hall, Suffolk

Saltram, Devon

Sandringham, Norfolk

Smithills Hall, Lancashire

Speke Hall, Lancashire

Stanway House, Gloucestershire

Stoke Park, Buckingham

Stourhead, Wiltshire

Sutton Place, Surrey

Sydenham House, Devon

The Deanery Gardens, Sonning

The Vyne, Basingstoke Hampshire

Tythrop House, Oxfordshire

Waddesdon Manor, Buckinghamshire

Wakehurst Place, Sussex

Wentworth Castle, Yorkshire

West Dean Park, Sussex

Westwood Park, Worcestershire

Wilton House, Salisbury

Wolfeton House, Dorset

Wroxton Abbey, Oxfordshire

Quenby Hall, Leicestershiro

Ragdale Old Hall, Leicestershire

Ribston Hall, Knaresborough, Yorkshire

Rothamsted, Harpenden, Hertfordshire

St. Donats Castle, Glamorganshire Samlesbury Hall, Lancashire

Sizergh Castle, Kendal, Westmorland

Stockton House, Wiltshire

Temple Newsam, Yorkshire

The Grange, Honiton, Devonshire

Treasurer's House, York

Welbeck Abbey, Worksop, Nottinghamshire

Westonbirt House, Tatburg, Gloucestershire

Woodsome Hall, Huddersfield, Yorkshire

Woollas Hall, Pershore, Worcestershire

"A veritable revelation of the wealth of internal adornments, architectural and other, contained in the great country mansions of England. To turn over the pages of the volume is to obtain keen pleasure, as well as enlightenment, concerning a treasury of domestic art and archæology, which to a large extent is kept closed from the common eye."-Scotsman.

"A very dignified volume with an immense number of fine photographs and historical and descriptive letterpress." -Times.

"Such a work as IN ENGLISH Homes comes as something of a revelation. One may have a general idea, or even some particular knowledge of the splendours of architecture, decoration, furniture, and works of art appertaining to our country mansions, and yet be astonished at all the taste and magnificence represented in the profusion of excellent photographs."-Morning Post.

Published at the Offices of Country LifE, LTD., 20, Tavistock Street, Covent Garden, W.C., and by George Newnes, Lrd., 7-12, Southampton Street, Strand, W.C. 


\section{THE GARDENS OF ITALY.}

Being a series of Illustrations from Photograplss specially taken by CHARLES LATHAM, of the most famons examples of those magnificent features of garden arrangement and architecture for which Italy, pre-eminently the earliest home of the garden, is noted, with descriptive text by EVELYN MARCH PHILLIPPS. This most important work, which forms a handsome companion to "Gardens Old and Nere," contains about 300 Plates, and is issued in two volumes, handsomely bound in cloth. $\quad £ 3$ 3s. Net; by post, $£ 34 \mathrm{~s}$.

\section{The following are the principal Gardens Illustrated-}

\section{VOLUME I.}

Villa Albani, Rome.

Villa Pamphilj Doria, Rome.

The Vatican Gardens, Rome.

Villa Borghese, Rome.

Gardens of the Quirinal, Rome.

Villa Medici, Rome.

The Colonna Gardens, Rome.

Palazzo Borghese, Rome.

Fountain of Trevi, Rome.

Palazzo Doria, Rome.

Palazzo Barberini, Rome.
Palazzo Brancaccio, Rome.

Villa Parisi, Frascati.

Villa Sciarra, Rome.

The British Embassy, Rome.

Villa Barberini, Castel Gandolfo.

Villa D'Este, Tivoli.

Villa Falconieri, Frascati.

Mondragone, Frascati.

Villa Torlonia, Frascati.

Villa Aldobrandini, Frascati.

\section{VOLUME II.}

Villa Farnese, Caprarola.

Villa Lante, Bagnaia.

Villa Palmieri, Florence.

Villa Garzoni, Collodi.

The Boboli Gardens, Florence.

Villa Bondi, Florence.

Villa Salviati, Florence.

Villa Medici, Florence.
Villa I Collazzi, Florence.

Castello and Petraja, near Florence.

Villa Gamberaia, Florence.

Villa Capponi, Florence.

Villa Fabricotti and Villa Stibbert, Florence.

Villa Montalto, Florence.

"The two volumes are worthy of their splendid subject, and it would be hard to wish for a better companion in an English garden than these exquisite pictures, gathered from the best of all in Italy. Scarcely a single garden of the first importance seems to have been omitted. We are sure that no one who knows Italy, even in the scantiest way, will put down Mr. Latham's volumes till he reaches the last of these exquisite reproductions."-Daily Telegraph.

"The natural and artistic beauties of the famous palace or vilia gardens of I ialy are most admirably illustrated, and with such variety and success as must be reckoned among the triumphs of photographic work." -Westminster Gazette.

"In the two handsome volumes a clear idea is given, by illustrations and letterpress, of the wonderful beauty of places to which the ordinary tourist seeks admittance in vain." -Yorkshire Post.

"The illustrations are among the best of their kind that we have seen, especially in their rendering of distances of contrasted effects of light and shade. The grouping of arcbitectural subjects--often an insurmountable difficulty-is managed with skill, the artist's feeling for composition enabling him frequently to make a good picture out of the material which is hardly within the photographer's customary limits." -Globe.

Published at the Offices of Country Life, Ltd., 20, Tavistock Street, Covent Garden, W.C., and by George Newnes, Lrd., 7-12, Southampton Street, Strand, IV.C. 


\section{TOYS OF OTHER DAYS.}

By Mrs. F. Nevill Jackson.

Price 21s. Net.

An interesting history of the playthings of children from prehistoric times up till the first half of the Igth century. Although a book of absorbing interest to the little ones, it is also a volume for connoisseurs; for fine examples of miniature furniture, toy services of Leeds and Staffordshire, salt glaze and specimens of silver toys from famous European collections, are among the subjects ably described by the authoress. Over 200 fine illustrations.

NORTH, SOUTH, AND OVER THE SEA.

By M. E. Francis. Author of "Pastorals of Dorset," "Fiander's Widow," etc., rith Illustvations by Mr.H. M. BROCK. Pvice 6s.

"In certain moods there is no one with whom swe would more contentedly settle down to a quiet tale of country life and character than Mrs. Francis Blundell. She knows and sympathises with the people she describes, and is always abundantly conscious of their humour." - Times.

"This is a collection of small masterpieces. Mrs. Blundell has studied shrewdly and affectionately the peasant of the North and the South and the Emerald Island, and reproduced their characteristics in a series of idylls in which sentiment and humour, the real and the ideal, are delightfully and convincingly blended." -Pilot.

\section{THE RIGGLESES AND OTHERS.}

By Evelyne E. Rynd.

Price 6s.

Miss Rynd, the brilliant young writer who made such a hit with "Mrs. Green," has written a book much in the same vein, only that the humour is much brighter and touched with a finer pathos, while the wit is keener than ever. The scene is the same as before, viz., a village in Kent, and the characters are for the most part in the same status in society as the immortal charwoman. But light as is the vein, the authoress touches some of the deepest issues of life, and although it is always with a laugh, it is also with tenderness and insight. The book will be found to be a great advance on her previous work.

\section{WHERE THE FOREST MURMURS.}

By Fiona Macleod, being a Series of Nature Essays.

6s. Net; by post, $6 s .4 d$.

"No other than Fiona Macleod could so have transfigured Nature into dream, no other writer could have expressed with such unity of spirit the Celtic attitude in terms of country things. She finds the charm of the mountain in their contemplation from the valley, the forest most vividly itself when the twigs are bare and the mosses shrouded in snow, the most luminous moment of the cuckoo's year in its first days of silence, and her love of all things greatest when they have just been taken away."-Morning Post.

"There is everywhere a sense of the haunting mystery of the processes of the world viewed through the eyes of a simple unsophisticated nature, which, from perpetual brooding upon the face of the deep, has caught something of the misty air and broken music of the waves. Suggestion, rather than doctrine, is the atmosphere of the work; and in a certain vague, but beautiful suggestiveness, the strange but eager-hearted prose of this writer abounds to the very brim."-Daily Telegraph.

\section{ECONOMIES IN DAIRY FARMING.}

A New and Important Work on Dairying, by Mr. ERNEST MAthews (the well-known Judge and Expert). 7s. 6d. Nct; by post, 7s. Iod.

"The author of this book is so well-known among farmers, especially those interested in the selection and judging of cows, that his name and experience alone will go far to ensure that his views receive the attention they deserve. $\mathrm{He}$ has for many years past been judge in all the most important butter tests which have been held at our principal agricultural shows."-The Journal of the Bath and West of England Society.

Published at the Offices of Country LiFe, LTD., 20, Tavistock Street, Covent Garden, W.C., and by GEORGE NEWNES, LTD., 7-I2, Southampton Street, Strand, W.C. 


\section{"Country Life" Library of Sport}

Edited by Mr. Horace G. Hutchinson.

A Series devoted to Sport and Pastime, each branch being dealt with by the most qualified experts on the subjects which they have made peculiarly their own. A special feature has been made of the reproduction of old sporting prints.

\section{SHOOTING.}

IN Two Volumes.

THE BREEDING, REARING AND SHOOTING OF PHEASANTS, PARTRIDGES AND WILD DUCK.

\section{5/- Net. 12/6 Net per Volume.}

The Globe.

"Mr. Hutchinson and his colleagues have done their work thoroughly. A notable feature of the work is the wealth and excellence of the pictorial illustrations. Most of these are from photographs, admirably reproduced; but there are also some quaint woodcuts as headpieces and tail-pieces. We may feel pretty sure that these two volumes will be speedily added to many a country-house library."

Standard.

"All that relates to the rearing and preservation of game, the situation of coverts, the arrangement of drives, and the selection of 'guns' is so exhaustively set out in these pages, that the purchaser of the book will have little need to consult either Lord Walsingham or Sir Ralph Payne Galway, or any other recognised authority, for information on the subject."

\section{FISHING.}

In Two Volumes.

With Coloured Plates of Salmon and Trout Flies. Over 250 Full Page Illustrations with various diagrams.

\section{5/- Net. 12/6 Net per volume.}

\section{Fishing Gazette.}

"I know pretty well every book in our language, and in French and German, on the subject of fishing, but I know no work which is so good, comprehensive and cheap as this. Would be worth buying if it were merely for the illustrations, for there are more than two hundred full-page plates, chiefly, if not entirely, from original photographs of fishing scenes in this country, in Norway, America, etc. ; then there are many bead and tail pieces reproduced from old prints, and angling books, and the coloured plates, the whole forming a most interesting piscatorial pictorial album."

Morning Post.

"Few books on any sport, and perhaps none on fishing, have ever deserved better the description 'thorough.' To its title-page might well have been added the motto of the Royal Agricultural Society, 'Science with Practice,' and to the title itself, 'The Angler's Encyclopædia.' From Cornwall to John O'Groats, from Wales to Norway, from Florida to India and Burma-here you may find what there is to be caught and how to eatch it. And no detail seems to have been overlooked. Localities, bait, tackle, choice of rods, methods of casting, likely times-all are fully covered by experts who write from long experience, and not because they spend odd days of the week going a-fishing and resolved to write a book about it. . The book is profusely, delightfully, and usefully illustrated. The salmon flies are excellent, and so are the prints showing right and wrong metbods of casting, bringing in a fish, and gaffing." 


\section{CRICKET.}

With over 80 Illustrations taken from the most interesting of the old Cricketing Prints.

\section{2/6 Net.}

The Sportsman.

"Clearly printed and ably turned out, the volume consists of some 450 pages of literary matter, but its chief feature is without a doubt the photographic reproductions of historioal pictures and prints. They number some eighty, and depict the game under its varied phases of the last 160 years, the humorous as well as the instructive side finding a place. There are illustrations of play and novel surroundings, portraits of old-time celebrities, and lastly, but not least, reproductions of pencil drawings by G. F. Watts, R.A., of the various strokes, 'the draw,' the leg volley,' "the cut,' "the block, and 'forward play.'"

\section{Glasgow Herald.}

"Its most distinctive feature is that it presents a collection such as has never before been given to the public of interesting old prints illustrative of England's national game. These form in some measure a picture-history of the game."

\section{BIG GAME SHOOTING}

In Two Volumes.

With over 200 Illustrations from Photographs showing Animals in their actual habitat and natural environment.

\section{5/- Net. 12/6 Net per Volume.}

The Scotsman.

"The illustrations demand special notice. Instead of the somewhat banal 'trophies' with which works of the kind are illustrated, the Editor has gathered together a number of admirable photographs of wild beasts in their haunts, the work of men who are themselves experienced game shooters. Many of these are of the utmost interest."

Sporting Life.

names of those who have assisted in the compilation of the work stamp it at once as being the standard work of the day on the sport in question. . . Eminently practical. - Will rank, without doubt, as the authority on Big Game Shooting for many a long day to come."

\section{POLO PAST \& PRESENT}

The origin and development of the game and the methods and practice of modern Polo.

\section{$12 / 6$ Net.}

The Field.

"Polo Past and Present' deals with the subject to the minutest detail, and the book is filled with useful hints and maxims. The style in which the information is proffered gains for the author the confidence of the reader, and to those who are interested in the subject comes the satisfaction, as they lay the book aside, that they have gained knowledge in the historical, theoretical, and practical views of polo. It is given to few writers to thoroughly realise the niceties which surround the modern circumstance. In this Mr. Dale is particularly fortunate, for not only may the novice become initiated in what best concerns him, but the experienced may find pleasure in digesting the reminiscence of an observant mind. Regimental polo, elementary polo, and the training of the polo pony, each has its chapter, to be followed with an excellent treatise on tournament polo and team-play, certainly the most instructive message the book contains, and well worthy the consideration of the player. Mr. Dale gives detailed consideration to combination in match teams, and explains the why and wherefore, not always an easy task even for those who are high exponents of the game. Umpires and referees are given their corner, and many wholesome words of advice are spoken to guide the fulfilment of their duties. A very good chapter on the management and care of polo grounds will prove of service to the troubled spirits of hard worked secretaries, and the book closes with varied and complete information on polo in Australia and America; rules of England and India; a full-fledged appendix of useful information; and last, but not least, a thoroughly efficient index."

London: Published at the Offices of "Country Life," Ltd., Tavistock Street, Covent Garden; and by George Newnes, Lid., Southampton St., Strand, W.C. 


\section{GOLF GRENS AND \\ GREEN-KEEPING}

Edited by Horace G. Hutchinson.

Price 10/6; by Post, 10/11.

HE principal intention of this volume is that it shall serve as a guide to the man who finds himself confronted with the very considerable problems involved in laying out a new Golf green, and also as an aid to the green-keeper and the green committee who are entrusted by a Golf club with the duty of maintaining the green in the best possible condition.

"The practical worth of the volume is nearly equal to the combined worth of all the books that have been written on the theory and practice of golf."-Yorkshire Daily Post.

\section{HALF A CENTURY OF SPORT IN HAMPSHIRE}

Being extracts from the shooting journals of JAMES EDWARD, second Earl of Malmesbury, with a prefatory memoir by his great-grandson the fifth Earl.

Edited by F. G. Aflalo.

\section{Price $10 / 6$ net; by Post, 10/11.}

"While primarily of fascinating interest to the sportsman, the work will be cordially welcomed by the nature lover, who will place it alongside the masterpiece of Gilbert White."-Manchester Courier.

LONDON: PUBLISHED AT THE OFFICES OF "COUNTRY LIFE," LTD., TAVISTOCK STREET, COVENT GARDEN; AND BX GEORGE NEWNES, LTD., SOUTHAMPTON ST., STRAND, W.C. 


\section{COUNTRY LIFE}

\section{THE JOURNAL FOR ALL INTERESTED IN COUNTRY LIFE AND COUNTRY PURSUITS}

Subscription Prices per annum (Post free): Inland, 29s. 2d.: Foreign, 47s. Weekly, Price, 6d.

$\mathrm{C}$ OUNTRY LIFE is a weekly journal addressed to all interested in country life and country pursuits. One of its main features is the celebrated series of CodnTRY Homes and GaRdens OLD AND NEw; in each number a country seat, remarkable either for its beauty or something peculiarly instructive in the architecture of the house, gardens or grounds, is elaborately illustrated in a manner that has proved of high service to those engaged in building and laying out or improving their estates. Other features of rural life are dealt with in an equally thorough manner. The methods pursued on our most famous estates and farms are minutely described, and photographs of the finest pedigree stock and the best machinery are given. All forms of healthy outdoor sport are described and illustrated in their season. In no case, however, are the facts set forth dry, as the journal numbers among its contributors some of the most graceful and accomplished writers of the present day. New books are also described and discussed by competent critics, so that altogether the journal is calculated to give the best news and views on all subjects that are of interest in cultivated circles, and the wholesomeness and fine open-air feeling that pervades its pages have almost become proverbial. CounrRY LIFE has, in fact, become indispensable.

Daily Telegraph. - "Country Life' is generally admitted to be the most beautifully produced of all the weeklies. Its process illustrations are unmatched, and the letterpress is always carefully selected and good in quality."

Westminster Gazette.- "To say of "Country Life" that it is one of the best of our illustrated productions is stating only balf a fact, inasmuch as in some of its features it stands alone. Its splendid gallery of stately mansions, beautiful interiors, and grand old gardens are incomparable."

Dally Mail.- "Country, Life" has established itself as the most beautifully produced weekly journal in the world."

Daily News.- " There is no feature of life in the country that is untouched, and a bound volume of "Country Life" is a real joy to possess and frequently to turn over."

Spectator.- "Country Life" amply fulfils its promise of being "the jouraal for all interested in country life and country pursuits."

Liverpool Daily Courier.-- "There is scarcely a number without one or more contributions of literary or otber interest which will stand reading, re-reading and study."

LONDON : POBLISHED AT THK OFYICHS OF " COUNTEY LHE," LTD., TAVISTOCK ST, COVENT GARDEN ; AND BY GEORGI NEWNIS, LTD., SOUTHAMPTON ST., STRAND, W, 


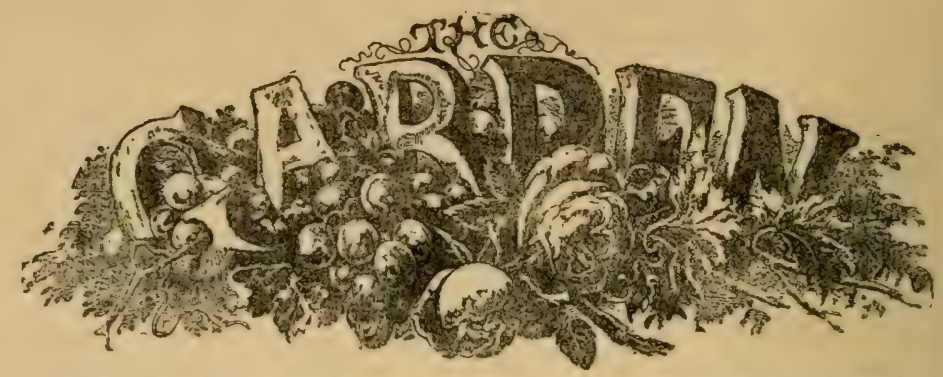

The Leading Gardening Newspaper for Amateur and Professional Gardeners.

\section{PRIGE ONE PENNY WEEKLY.}

THE FLOWER GARDEN.

THE ROSE GARDEN.

THE WALL AND WATER GARDEN.
NEW AND RARE PLANTS. THE KITCHEN GARDEN. THE FRUIT GARDEN. ORCHIDS, \&cu, \&C.

Since "The Garden" has been reduced from threepence to one penny, its success has been extraordinary. It meets the requirements of both PROFESSIONAI and AMATEUR GARDENERS. It is circulating rapidly amongst BEGINNERS IN GARDENING, and the great feature of helping readers by greatly extending the ANSWERS TO CORRESPONDENTS has been much appreciated. All branches of gardening are fully considered, and descriptions and illustrations in colcur and black and white of new plants, the Flower Garden, Rose Garden, Kitohen Garden, Fruit Garden, and Wall and Water Garden are given

"The Garden" is THE gardening paper wherein to learn the best ways of making a success of the smallest and largest gardens. It is a paper for all to study who wish to thoroughly master the art of gardening.

GARDENING FOR BEGINNERS AND ANSWERS TO CORRESPONDENTS A SPECIAL FEATURE.

VALUABLE PRIZES OFFERED FOR COMPETITION. A COLOURED PLATE IS GIVEN WITH ALTERNATE ISSUES.

CONSULT THE ADVERTISEMENT PAGES FOR EVERY REQUISITE FOR THE GARDEN.

TO BE HAD OF ALL NEWSAGENTS \& BOOKSTALLS.

Specimen Copy post free from the Manager, "The Garden," 20, Tavistock Street, Covent Garden, W.C. 

$\because 1010$

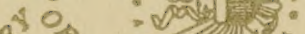

$i^{0} \pi$

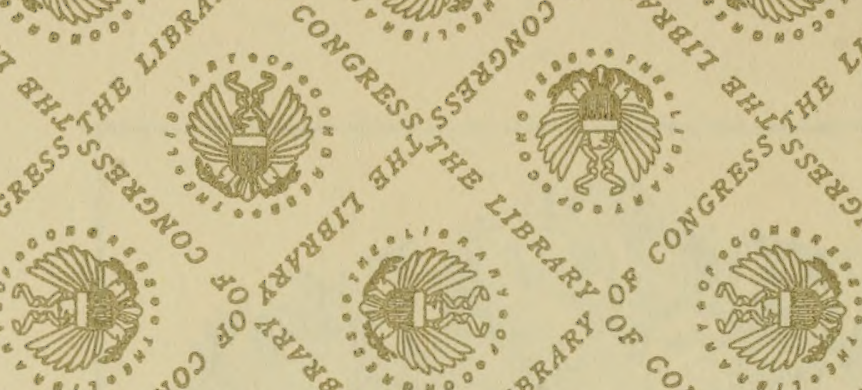

is $5^{5^{2}}=2$

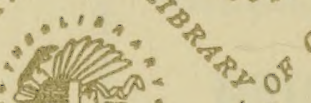
$0^{2}$

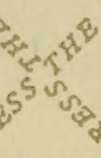

$\therefore$

- 400 क

$\therefore$ " का

"

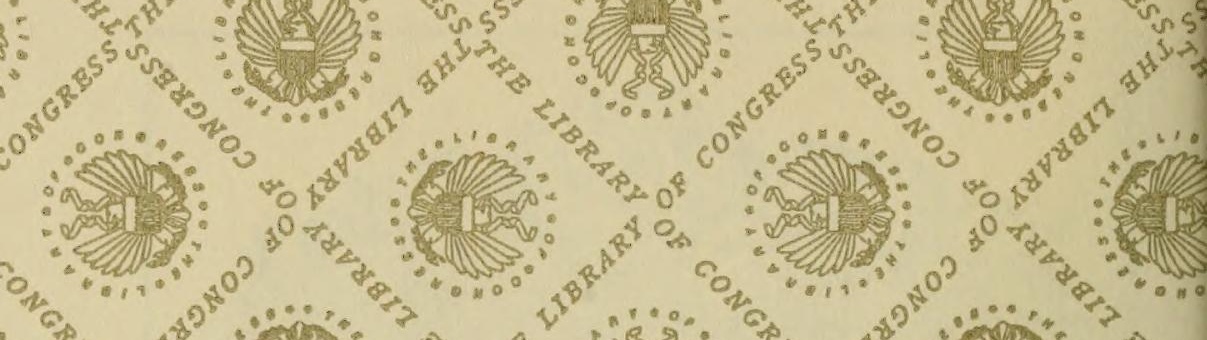

- हैं०

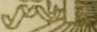
is $\therefore \%$

2
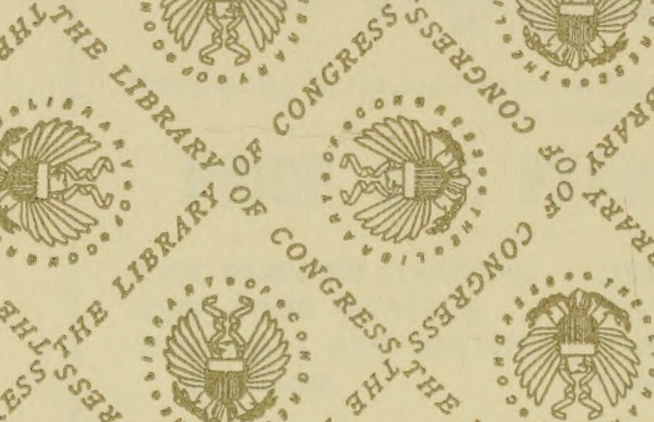


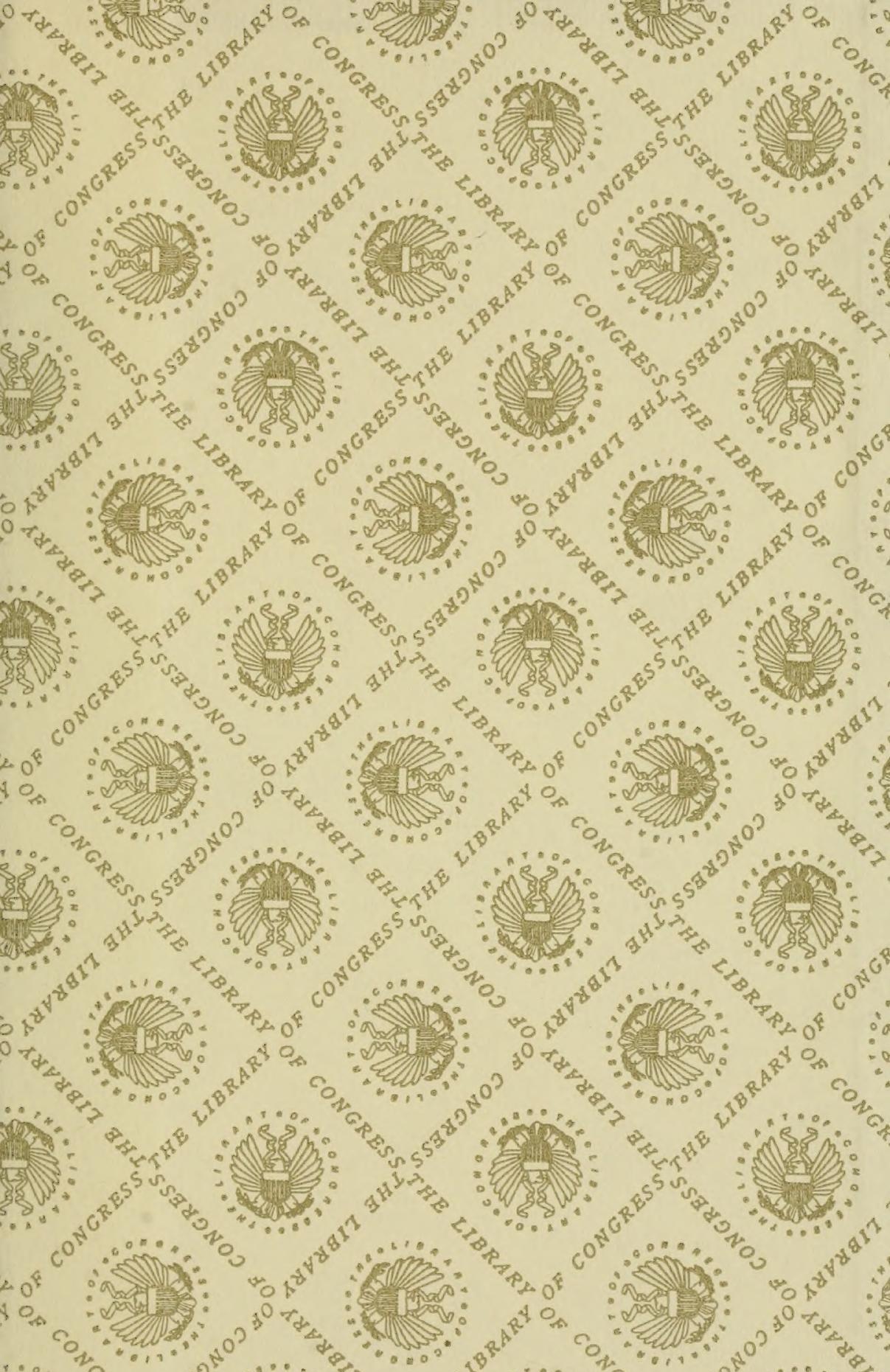




\section{LIBRARY OF CONGRESS

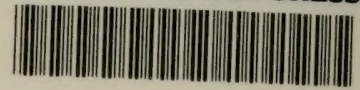

00009136125 